\title{
Diagnóstico ambiental em manguezais dos complexos estuarinos da Baixada Santista e de Cananéia - São Paulo, no tocante a metais e compostos organoclorados
}

\section{Elke Cliquet Simões}

Dissertação apresentada ao Instituto de Química de São Carlos, da Universidade de São Paulo para obtenção do título de Mestre em Ciências (Química Analítica)

Orientadora: Profa Dra Maria Olímpia de Oliveira Rezende

São Carlos

2007 
AUTORIZO A REPRODUÇÃO E DIVULGAÇÃO TOTAL OU PARCIAL DESTE TRABALHO, POR QUALQUER MEIO CONVENCIONAL OU ELETRÔNICO, PARA FINS DE ESTUDO E PESQUISA, DESDE QUE CITADA A FONTE 


\section{Dedico}

Ao meu pai, que antes de partir, não deixou apenas saudades.....deixou o exemplo de uma vida inteira de trabalho, dedicação, humildade e honestidade.....deixou o exemplo da construção de uma família que se ama e se respeita.....exemplos que me lembram, todos os dias, que o esforço vale a pena.......

À minha mãezinha que, com sua admirável capacidade de doar, me apoiou tantas e tantas vezes... uma mulher forte que está sempre disposta a nos aquecer em seu colo e nos dar o que há de mais belo na natureza.....

o amor incondicional de mãe...te amo

Ao homem que me traz a cada dia, a sensação de ser bela e amada.... ao homem que faz eu me sentir feliz, realizada...... ao homem que me orgulha com seus princípios e caráter...ao pai dos meus futuros filhos.....meu grande amor..... meu Merino..... 


\section{AGRADECIMENTOS}

- À professora Dra. Maria Olímpia de Oliveira Rezende pela orientação

- Ao CNPq pela bolsa concedida

- Aos meus irmãos que tanto fazem por mim, me dando mais amor e carinho do que eu preciso e me mimando cada vez mais e mais... os quais eu não consigo falar sem chorar

- Aos meus amados sobrinhos e sobrinhas.... que me dão o prazer de sorrir

- Aos meus sogros.... quer dizer... meus segundos pais! Os quais eu tanto amo! Obrigada por estarem sempre conosco, por toda ajuda, apoio e incentivo e principalmente por todo amor que vocês têm por nós!! Amamos vocês!!!!!

- Aos meus cunhados e cunhadas que eu tenho tanto carinho!

- Aos tios, tias, primos, primas e considerados como..........obrigada por estarem sempre presentes nos dando apoio!!

- Aos meus amigos de Santos, São Paulo, Valinhos e outros perdidos por aí.......... afinal...... eu desapareço! Mas não esqueço!!!

- À minha família de São Carlos que acompanham as minhas loucuras ........ Daniel, Thais, Aline, Milena, Joel, Raquel, Soninha, Daniboy, Daniel, Eliane, Toni, Giba, Onda, Lu e Igor ..... e em especial a Paula (minha filha do coração)

- A todos os amigos que passaram pelo laboratório de química ambiental..... obrigada pela colaboração!

- À Tulipa, Tommy, Bruma e Sioux minhas paixões

- À Cris pelos incríveis "quebra-galhos" em meu lar-doce-lar

- Ao Paulo e Carlinhos (CAQUI) pela ajuda com o ICP

- Ao Sr. Percio (Cananéia)...... obrigada pelo passeio

- Ao pessoal do CHREA pelo horiba.... obrigada pela gentileza

- Ao professor Dr. Zara (UNESP-São Vicente) pelo apoio

- À Ślvia e à Andréa (secretaria da pós) pela disposição e dedicação em nos ajudar.... obrigada!

- Aos guardinhas e faxineiras pela amizade......

- A todos que direta ou indiretamente colaboraram para a realização deste trabalho, o meu mais sincero agradecimento. 


\section{LISTA DE ILUSTRAÇÕES}

Figura 1: Espécies de mangue mais freqüentes nos manguezais do estado de São Paulo

Figura 2: Características das espécies de mangue mais freqüentes nos manguezais do estado de São Paulo

Figura 3: Distribuição da área de ocupação dos manguezais, por região, no estado de São Paulo

Figura 4: Mapeamento das áreas correspondentes a manguezais de parte da Baixada Santista

Figura 5: Mapeamento das áreas correspondentes a manguezais de parte do Complexo Estuarino de Cananéia-Iguape

Figura 6: Distribuição da matéria orgânica no ambiente

Figura 7: Modelo de estrutura de ácidos húmicos proposto por Schulten e Schnitzer

Figura 8: Modelo de estrutura de ácidos húmicos em 3D proposto por Schulten e Schnitzer

Figura 9: Estabilidade de espécies de cádmio em variações de $p H$ e potencial redox

Figura 10: Estabilidade de espécies de chumbo em variações de pH e potencial redox

Figura 11: Estruturas dos compostos organoclorados deste estudo

Figura 12: Isômeros de alguns dos compostos organoclorados deste estudo

Figura 13: Algumas características das proximidades dos pontos de coleta - Baixada Santista

Figura 14: Algumas características das proximidades dos pontos de coleta - Cananéia

Figura 15: Pontos de coleta na Baixada Santista

Figura 16: Pontos de coleta no Complexo Estuarino de Cananéia-Iguape

Figura 17: Diagrama esquemático de uma fonte de plasma de argônio

Figura 18: Representação da emissão atômica

Figura 19: Esquema dos principais componentes de um ICP-AES

Figura 20: Extrator Soxhlet

Figura 21: Principais etapas em SPE, visando o isolamento de um analito 
Figura 22: Esquema de Cromatografia a Gás

Figura 23: Esquema do Detector de Captura de Elétrons

Figura 24: Rampa de Temperatura para a separação dos compostos organoclorados

Figura 25: Gráfico de comparação dos parâmetros estudados em amostras de água em cinco pontos de coleta do complexo estuarino da Baixada Santista

Figura 26: Gráfico de comparação dos parâmetros estudados em amostras de água em cinco pontos de coleta do complexo estuarino de Cananéia

Figura 27: Gráfico de comparação dos parâmetros estudados em amostras de sedimento em cinco pontos de coleta do complexo estuarino da Baixada Santista

Figura 28: Gráfico de comparação dos parâmetros estudados em amostras de sedimento em cinco pontos de coleta do complexo estuarino de Cananéia

Figura 29: Gráficos de Calibração para a determinação de metais por ICP-AES

Figura 30: Gráfico de comparação das concentrações de metais pseudo-totais em amostras de água em cinco pontos de coleta do complexo estuarino da Baixada Santista

Figura 31: Gráfico de comparação das concentrações de metais pseudo-totais em amostras de água em cinco pontos de coleta do complexo estuarino de Cananéia

Figura 32: Gráfico de comparação das concentrações de metais pseudo-totais em amostras de sedimento em cinco pontos de coleta do complexo estuarino da Baixada Santista

Figura 33: Gráfico de comparação das concentrações de metais pseudo-totais em amostras de sedimento em cinco pontos de coleta do complexo estuarino de Cananéia

Figura 34: Gráfico de comparação das concentrações de metais pseudo-totais em amostras de folhas de Avicennia schaueriana (mangue preto) em cinco pontos de coleta do complexo estuarino da Baixada Santista

Figura 35: Gráfico de comparação das concentrações de metais pseudo-totais em amostras de raizes de Avicennia schaueriana (mangue preto) em cinco pontos de coleta do complexo estuarino da Baixada Santista

Figura 36: Gráfico de comparação das concentrações de metais pseudo-totais em amostras de folhas de Laguncularia racemosa (mangue branco) em cinco pontos de coleta do complexo estuarino da Baixada Santista

Figura 37: Gráfico de comparação das concentrações de metais pseudo-totais em amostras de raízes de Laguncularia racemosa (mangue branco) em cinco pontos de coleta do complexo estuarino da Baixada Santista 
Figura 38: Gráfico de comparação das concentrações de metais pseudo-totais em amostras de folhas de Rhizophora mangle (mangue vermelho) em quatro pontos de coleta do complexo estuarino da Baixada Santista

Figura 39: Gráfico de comparação das concentrações de metais pseudo-totais em amostras de raizes de Rhizophora mangle (mangue vermelho) em quatro pontos de coleta do complexo estuarino da Baixada Santista

Figura 40: Gráfico de comparação das concentrações de metais pseudo-totais em amostras de folhas de Avicennia schaueriana (mangue preto) em quatro pontos de coleta do complexo estuarino de Cananéia

Figura 41: Gráfico de comparação das concentrações de metais pseudo-totais em amostras de raízes de Avicennia schaueriana (mangue preto) em quatro pontos de coleta do complexo estuarino de Cananéia

Figura 42: Gráfico de comparação das concentrações de metais pseudo-totais em amostras de folhas de Laguncularia racemosa (mangue branco) em cinco pontos de coleta do complexo estuarino de Cananéia

Figura 43: Gráfico de comparação das concentrações de metais pseudo-totais em amostras de raízes de Laguncularia racemosa (mangue branco) em cinco pontos de coleta do complexo estuarino de Cananéia

Figura 44: Gráfico de comparação das concentrações de metais pseudo-totais em amostras de folhas de Rhizophora mangle (mangue vermelho) em cinco pontos de coleta do complexo estuarino de Cananéia

Figura 45: Gráfico de comparação das concentrações de metais pseudo-totais em amostras de raizes de Rhizophora mangle (mangue vermelho) em cinco pontos de coleta do complexo estuarino de Cananéia

Figura 46a: Gráfico de comparação das concentrações de metais pseudo-totais em diferentes matrizes do ponto 1 do complexo estuarino da Baixada Santista_

Figura 46b: Gráfico de comparação das concentrações de metais pseudo-totais em diferentes matrizes do ponto 1 do complexo estuarino da Baixada Santista

Figura 47a: Gráfico de comparação das concentrações de metais pseudo-totais em diferentes matrizes do ponto 2 do complexo estuarino da Baixada Santista

Figura 47b: Gráfico de comparação das concentrações de metais pseudo-totais em diferentes matrizes do ponto 2 do complexo estuarino da Baixada Santista

Figura 48a: Gráfico de comparação das concentrações de metais pseudo-totais em diferentes matrizes do ponto 3 do complexo estuarino da Baixada Santista 
Figura 48b: Gráfico de comparação das concentrações de metais pseudo-totais em diferentes matrizes do ponto 3 do complexo estuarino da Baixada Santista

Figura 49a: Gráfico de comparação das concentrações de metais pseudo-totais em diferentes matrizes do ponto 4 do complexo estuarino da Baixada Santista

Figura 49b: Gráfico de comparação das concentrações de metais pseudo-totais em diferentes matrizes do ponto 4 do complexo estuarino da Baixada Santista

Figura 50a: Gráfico de comparação das concentrações de metais pseudo-totais em diferentes matrizes do ponto 5 do complexo estuarino da Baixada Santista

Figura 50b: Gráfico de comparação das concentrações de metais pseudo-totais em diferentes matrizes do ponto 5 do complexo estuarino da Baixada Santista

Figura 51a: Gráfico de comparação das concentrações de metais pseudo-totais em diferentes matrizes do ponto 1 do complexo estuarino de Cananéia

Figura 51b: Gráfico de comparação das concentrações de metais pseudo-totais em diferentes matrizes do ponto 1 do complexo estuarino de Cananéia

Figura 52a: Gráfico de comparação das concentrações de metais pseudo-totais em diferentes matrizes do ponto 2 do complexo estuarino de Cananéia

Figura 52b: Gráfico de comparação das concentrações de metais pseudo-totais em diferentes matrizes do ponto 2 do complexo estuarino de Cananéia

Figura 53a: Gráfico de comparação das concentrações de metais pseudo-totais em diferentes matrizes do ponto 3 do complexo estuarino de Cananéia

Figura 53b: Gráfico de comparação das concentrações de metais pseudo-totais em diferentes matrizes do ponto 3 do complexo estuarino de Cananéia

Figura 54a: Gráfico de comparação das concentrações de metais pseudo-totais em diferentes matrizes do ponto 4 do complexo estuarino de Cananéia

Figura 54b: Gráfico de comparação das concentrações de metais pseudo-totais em diferentes matrizes do ponto 4 do complexo estuarino de Cananéia

Figura 55a: Gráfico de comparação das concentrações de metais pseudo-totais em diferentes matrizes do ponto 5 do complexo estuarino de Cananéia

Figura 55b: Gráfico de comparação das concentrações de metais pseudo-totais em diferentes matrizes do ponto 5 do complexo estuarino de Cananéia

Figura 56: Cromatograma da separação de 19 compostos organoclorados

Figura 57a: Gráficos de Calibração para a determinação de organoclorados por GC-ECD 
Figura 58: Gráfico de comparação das concentrações de organoclorados em amostras de sedimento em cinco pontos de coleta do complexo estuarino da Baixada Santista

Figura 59: Gráfico de comparação das concentrações de organoclorados em amostras de sedimento em cinco pontos de coleta do complexo estuarino de Cananéia

Figura 60: Gráfico de comparação das concentrações de organoclorados em amostras de folhas de Avicennia schaueriana (mangue preto) em cinco pontos de coleta do complexo estuarino da Baixada Santista

Figura 61: Gráfico de comparação das concentrações de organoclorados em amostras de raizes de Avicennia schaueriana (mangue preto) em cinco pontos de coleta do complexo estuarino da Baixada Santista

Figura 62: Gráfico de comparação das concentrações de organoclorados em amostras de folhas de Laguncularia racemosa (mangue branco) em cinco pontos de coleta do complexo estuarino da Baixada Santista

Figura 63: Gráfico de comparação das concentrações de organoclorados em amostras de raizes de Laguncularia racemosa (mangue branco) em cinco pontos de coleta do complexo estuarino da Baixada Santista

Figura 64: Gráfico de comparação das concentrações de organoclorados em amostras de folhas de Rhizophora mangle (mangue vermelho) em quatro pontos de coleta do complexo estuarino da Baixada Santista

Figura 65: Gráfico de comparação das concentrações de organoclorados em amostras de raizes de Rhizophora mangle (mangue vermelho) em quatro pontos de coleta do complexo estuarino da Baixada Santista

Figura 66: Gráfico de comparação das concentrações de organoclorados em amostras de folhas de Avicennia schaueriana (mangue preto) em quatro pontos de coleta do complexo estuarino de Cananéia

Figura 67: Gráfico de comparação das concentrações de organoclorados em amostras de raízes de Avicennia schaueriana (mangue preto) em quatro pontos de coleta do complexo estuarino de Cananéia

Figura 68: Gráfico de comparação das concentrações de organoclorados em amostras de folhas de Laguncularia racemosa (mangue branco) em cinco pontos de coleta do complexo estuarino de Cananéia 
Figura 69: Gráfico de comparação das concentrações de organoclorados em amostras de raízes de Laguncularia racemosa (mangue branco) em cinco pontos de coleta do complexo estuarino de Cananéia

Figura 70: Gráfico de comparação das concentrações de organoclorados em amostras de folhas de Rhizophora mangle (mangue vermelho) em cinco pontos de coleta do complexo estuarino de Cananéia

Figura 71: Gráfico de comparação das concentrações de organoclorados em amostras de raizes de Rhizophora mangle (mangue vermelho) em cinco pontos de coleta do complexo estuarino de Cananéia

Figura 72: Gráfico de comparação das concentrações de organoclorados em diferentes matrizes do ponto 1 do complexo estuarino da Baixada Santista

Figura 73: Gráfico de comparação das concentrações de organoclorados em diferentes matrizes do ponto 2 do complexo estuarino da Baixada Santista

Figura 74: Gráfico de comparação das concentrações de organoclorados em diferentes matrizes do ponto 3 do complexo estuarino da Baixada Santista

Figura 75: Gráfico de comparação das concentrações de organoclorados em diferentes matrizes do ponto 4 do complexo estuarino da Baixada Santista

Figura 76: Gráfico de comparação das concentrações de organoclorados em diferentes matrizes do ponto 5 do complexo estuarino da Baixada Santista

Figura 77: Gráfico de comparação das concentrações de organoclorados em diferentes matrizes do ponto 1 do complexo estuarino de Cananéia

Figura 78: Gráfico de comparação das concentrações de organoclorados em diferentes matrizes do ponto 2 do complexo estuarino de Cananéia_

Figura 79: Gráfico de comparação das concentrações de organoclorados em diferentes matrizes do ponto 3 do complexo estuarino de Cananéia

Figura 80: Gráfico de comparação das concentrações de organoclorados em diferentes matrizes do ponto 4 do complexo estuarino de Cananéia

Figura 81: Gráfico de comparação das concentrações de organoclorados em diferentes matrizes do ponto 5 do complexo estuarino de Cananéia_ 


\section{LISTA DE TABELAS}

Tabela 1: Área de manguezais por município da Baixada Santista

Tabela 2: Área de manguezais por município do Litoral Sul do estado de São Paulo

Tabela 3: Concentrações limites de metais totais em solos e sedimentos. Valores em ppm $(\mathrm{mg} / \mathrm{kg})$ estabelecidos por diferentes fontes ${ }^{1}$

Tabela 4: Concentrações limites de metais em águas salobras da classe 1 (Resolução $n^{\circ} 357$ de 17/03/05 do CONAMA)

Tabela 5: Concentrações limites de compostos organoclorados em solos e sedimentos. Valores estabelecidos por diferentes fontes ${ }^{1}$

Tabela 6: Condições espectrométricas de análise

Tabela 7: Resposta relativa do detector ECD à algumas classes de compostos

Tabela 8: Caracterização das amostras de água

Tabela 9: Caracterização das amostras de sedimento

Tabela 10: Valores de LOD e LOQ encontrados e limites máximos permissíveis para metais a serem considerados neste estudo ${ }^{1}$

Tabela 11: Concentrações de metais pseudo-totais encontradas em amostras de sedimento e água dos complexos estuarinos estudados

Tabela 12: Concentrações de metais pseudo-totais encontradas em amostras de folhas de mangues dos complexos estuarinos estudados

Tabela 13: Concentrações de metais pseudo-totais encontradas em amostras de raízes de mangues dos complexos estuarinos estudados

Tabela 14: Valores de $L O D$ e $L O Q$ encontrados e limites máximos permissíveis para pesticidas organoclorados a serem considerados neste estudo ${ }^{1}$

Tabela 15: Valores de $R^{2}$ encontrados e avaliação, em diferentes concentrações, do método utilizado para determinar compostos organoclorados

Tabela 16: Concentrações de pesticidas organoclorados encontradas em amostras de sedimento dos complexos estuarinos estudados

Tabela 17: Concentrações de pesticidas organoclorados encontradas em amostras de folhas de mangues do complexo estuarino da Baixada Santista

Tabela 18: Concentrações de pesticidas organoclorados encontradas em amostras de folhas de mangues do complexo estuarino de Cananéia 
Tabela 19: Concentrações de pesticidas organoclorados encontradas em amostras de raízes de mangues do complexo estuarino da Baixada Santista

Tabela 20: Concentrações de pesticidas organoclorados encontradas em amostras de raízes de mangues do complexo estuarino de Cananéia 


\section{LISTA DE ABREVIATURAS E SIGLAS}

Siglas das amostras coletadas neste estudo:

W1 - amostra de águas no ponto 1 da Baixada Santista

W2 - amostra de águas no ponto 2 da Baixada Santista

W3 - amostra de águas no ponto 3 da Baixada Santista

W4 - amostra de águas no ponto 4 da Baixada Santista

W5 - amostra de águas no ponto 5 da Baixada Santista

CW1 - amostra de águas no ponto 1 de Cananéia

CW2 - amostra de águas no ponto 2 de Cananéia

CW3 - amostra de águas no ponto 3 de Cananéia

CW4 - amostra de águas no ponto 4 de Cananéia

CW5 - amostra de águas no ponto 5 de Cananéia

S1 - amostra de sedimento no ponto 1 da Baixada Santista

S2 - amostra de sedimento no ponto 2 da Baixada Santista

S3 - amostra de sedimento no ponto 3 da Baixada Santista

S4 - amostra de sedimento no ponto 4 da Baixada Santista

S5 - amostra de sedimento no ponto 5 da Baixada Santista

CS1 - amostra de sedimento no ponto 1 de Cananéia

CS2 - amostra de sedimento no ponto 2 de Cananéia

CS3 - amostra de sedimento no ponto 3 de Cananéia

CS4 - amostra de sedimento no ponto 4 de Cananéia

CS5 - amostra de sedimento no ponto 5 de Cananéia

FA1 - amostra de folha de Avicennia schaueriana no ponto 1 da Baixada Santista

FA2 - amostra de folha de Avicennia schaueriana no ponto 2 da Baixada Santista

FA3 - amostra de folha de Avicennia schaueriana no ponto 3 da Baixada Santista

FA4 - amostra de folha de Avicennia schaueriana no ponto 4 da Baixada Santista

FA5 - amostra de folha de Avicennia schaueriana no ponto 5 da Baixada Santista

FL1 - amostra de folha de Laguncularia racemosa no ponto 1 da Baixada Santista

FL2 - amostra de folha de Laguncularia racemosa no ponto 2 da Baixada Santista

FL3 - amostra de folha de Laguncularia racemosa no ponto 3 da Baixada Santista

FL4 - amostra de folha de Laguncularia racemosa no ponto 4 da Baixada Santista

FL5 - amostra de folha de Laguncularia racemosa no ponto 5 da Baixada Santista

FR2 - amostra de folha de Rhizophora mangle no ponto 2 da Baixada Santista 
FR3 - amostra de folha de Rhizophora mangle no ponto 3 da Baixada Santista FR4 - amostra de folha de Rhizophora mangle no ponto 4 da Baixada Santista FR5 - amostra de folha de Rhizophora mangle no ponto 5 da Baixada Santista CFA1 - amostra de folha de Avicennia schaueriana no ponto 1 de Cananéia CFA2 - amostra de folha de Avicennia schaueriana no ponto 2 de Cananéia CFA3 - amostra de folha de Avicennia schaueriana no ponto 3 de Cananéia CFA5 - amostra de folha de Avicennia schaueriana no ponto 5 de Cananéia CFL1 - amostra de folha de Laguncularia racemosa no ponto 1 da Cananéia CFL2 - amostra de folha de Laguncularia racemosa no ponto 2 da Cananéia CFL3 - amostra de folha de Laguncularia racemosa no ponto 3 da Cananéia CFL4 - amostra de folha de Laguncularia racemosa no ponto 4 da Cananéia CFL5 - amostra de folha de Laguncularia racemosa no ponto 5 da Cananéia CFR1 - amostra de folha de Rhizophora mangle no ponto 1 de Cananéia CFR2 - amostra de folha de Rhizophora mangle no ponto 2 de Cananéia CFR3 - amostra de folha de Rhizophora mangle no ponto 3 de Cananéia CFR4 - amostra de folha de Rhizophora mangle no ponto 4 de Cananéia CFR5 - amostra de folha de Rhizophora mangle no ponto 5 de Cananéia RA1 - amostra de raiz de Avicennia schaueriana no ponto 1 da Baixada Santista RA2 - amostra de raiz de Avicennia schaueriana no ponto 2 da Baixada Santista RA3 - amostra de raiz de Avicennia schaueriana no ponto 3 da Baixada Santista RA4 - amostra de raiz de Avicennia schaueriana no ponto 4 da Baixada Santista RA5 - amostra de raiz de Avicennia schaueriana no ponto 5 da Baixada Santista RL1 - amostra de raiz de Laguncularia racemosa no ponto 1 da Baixada Santista RL2 - amostra de raiz de Laguncularia racemosa no ponto 2 da Baixada Santista RL3 - amostra de raiz de Laguncularia racemosa no ponto 3 da Baixada Santista RL4 - amostra de raiz de Laguncularia racemosa no ponto 4 da Baixada Santista RL5 - amostra de raiz de Laguncularia racemosa no ponto 5 da Baixada Santista RR2 - amostra de raiz de Rhizophora mangle no ponto 2 da Baixada Santista RR3 - amostra de raiz de Rhizophora mangle no ponto 3 da Baixada Santista RR4 - amostra de raiz de Rhizophora mangle no ponto 4 da Baixada Santista RR5 - amostra de raiz de Rhizophora mangle no ponto 5 da Baixada Santista CRA1 - amostra de raiz de Avicennia schaueriana no ponto 1 de Cananéia CRA2 - amostra de raiz de Avicennia schaueriana no ponto 2 de Cananéia CRA3 - amostra de raiz de Avicennia schaueriana no ponto 3 de Cananéia CRA5 - amostra de raiz de Avicennia schaueriana no ponto 5 de Cananéia 
CRL1 - amostra de raiz de Laguncularia racemosa no ponto 1 da Cananéia

CRL2 - amostra de raiz de Laguncularia racemosa no ponto 2 da Cananéia

CRL3 - amostra de raiz de Laguncularia racemosa no ponto 3 da Cananéia

CRL4 - amostra de raiz de Laguncularia racemosa no ponto 4 da Cananéia

CRL5 - amostra de raiz de Laguncularia racemosa no ponto 5 da Cananéia

CRR1 - amostra de raiz de Rhizophora mangle no ponto 1 de Cananéia

CRR2 - amostra de raiz de Rhizophora mangle no ponto 2 de Cananéia

CRR3 - amostra de raiz de Rhizophora mangle no ponto 3 de Cananéia

CRR4 - amostra de raiz de Rhizophora mangle no ponto 4 de Cananéia

CRR5 - amostra de raiz de Rhizophora mangle no ponto 5 de Cananéia

Outras siglas citadas neste estudo:

AAS - Espectrometria de Absorção Atômica (Atomic Absorption Spectrometry)

AES - Espectrometria de Emissão Atômica (Atomic Emission Spectrometry)

ANVISA - Agência Nacional de Vigilância Sanitária

APA - Área de Proteção Ambiental

C - Concentração

CEC - capacidade de troca catiônica (Cation Exchange Capacity)

CETESB - Companhia de Tecnologia de Saneamento Ambiental

CONAMA - Conselho Nacional do Meio Ambiente

CV - coeficiente de variação

DCP - Plasma Corrente Contínua

DINAL - Divisão Nacional de Vigilância Sanitária de Alimentos

DO - oxigênio dissolvido (Dissolved Oxygen)

Exat - exatidão

EC - condutividade elétrica (Electrical Conductivity)

ECD - Detector de captura de elétrons (Electron Capture Detector)

Eh - Potencial Redox

EMBRAPA - Empresa Brasileira de Pesquisa Agropecuária

EPA - Agência de Proteção Ambiental Americana (Environmental Protection Agency)

FA - Ácidos Fúlvicos (Fulvic Acid)

GC - Cromatografia gasosa (Gas Chromatography)

GLP - Boas Práticas de Laboratório (Good Laboratory Practice)

$\mathbf{H}$ - umidade (Humidity) 
HA - Ácidos Húmicos (Humic Acid)

HS - Substâncias Húmicas (Humics Substances)

IBDF - Instituto Brasileiro de Desenvolvimento Florestal

ICP - Plasma Indutivamente Acoplado (Inductively Coupled Plasma)

ISQG - Interin Sediment Quality Guideline, são derivados do SQG e determinados quando os dados para confecção dos SQGs são disponíveis porém limitados.

IUPAC - International Union of Pure and Applied Chemistry

LOD - Limite de detecção (limit of deetection)

LOQ - Limite de quantificação (limit of quantification)

MIP - Manejo Integrado de Pragas

MIP - Plasma Induzido por Microondas (Microwave Coupled Plasma)

OM - matéria orgânica (Organic Matter)

PEL - Probably Effect Level, concentração a partir da qual provavelmente proporcionará efeito as formas de vida aquática ou aos aspectos de seu ciclo de vida aquática durante um período indefinido de exposição associada com sedimentos.

pH - potencial hidrogeniônico

POP - Poluentes Orgânicos Persistentes

$\mathbf{R}^{2}$ - Coeficiente de correlação

$\operatorname{Rec}$ - recuperação

RF - Radiofreqüência

$\mathbf{S}$ - salinidade (Salinity)

$\mathbf{S}$ - desvio padrão

SPE - Extração em fase sólida (Solid Phase Extraction)

SQG - Sediment Quality Guideline, concentrações numéricas que são definidas com a intenção de proteger todas as formas de vida aquática e todos os aspectos de seu ciclo de vida aquática durante um período indefinido de exposição associada com sedimentos.

STP - Substância Tóxicos Persistentes

$\mathbf{T}$ - temperatura

TSS - sólidos totais suspensos (Total Suspended Solids)

TOC - carbono orgânico total (Total Organic Carbon)

VA (T) - Valor de Alerta (T) é um valor médio entre outros dois valores (S e I) que indica que já ocorreu uma certa alteração que diminuiu, ainda que pouco, as propriedades funcionais do solo, sendo necessária uma investigação detalhada na área para quantificação dessa alteração.

VI (I) - Valor de Intervenção é o valor que indica um nível de qualidade do solo acima do qual existem riscos para a saúde humana e para o ambiente. A ultrapassagem deste valor indica a necessidade de ações voltadas a sua remediação. 
VP - Valor de Prevenção é a concentração de determinada substância que está relacionada a capacidade de um solo de sustentar as suas funções primárias e, valores acima deste indicam que podem ocorrer alterações prejudiciais na qualidade do solo. Deve ser utilizado para disciplinar a introdução de substâncias no solo e, quando ultrapassado, a continuidade da atividade será submetida a nova avaliação, devendo os responsáveis legais pela introdução das cargas poluentes proceder o monitoramento dos impactos decorrentes.

VR (S) - Valor de Referência que indica um nível de qualidade do solo considerado "limpo", permitindo assim, a sua utilização para qualquer finalidade.

VRQ - Valor de Referência de Qualidade é a concentração de determinada substância no solo que define este como limpo ou em sua qualidade natural. Deve ser utilizado como referência nas ações de prevenção à poluição e para o controle de áreas contaminadas. 


\section{RESUMO}

Os manguezais, grandes berçários da natureza que se encontram em quase todo o litoral brasileiro, são áreas que requerem o máximo de proteção contra distúrbios ambientais. Na Baixada Santista e na região de Cananéia Iguape, a atividade pesqueira é o principal subsídio para muitas famílias, porém vêm sendo ameaçada nos últimos anos pelo descaso com que esses ambientes são tratados. Este tão importante ecossistema que contribui para o controle do clima de cidades litorâneas e oferece madeiras, remédios, óleos e uma rica variedade de alimentos, também retém poluentes com muita facilidade, o que coloca em risco tanto a vida vegetal quanto animal, na qual se inclui o homem.

Diante desta preocupação, este trabalho visou avaliar substâncias potencialmente tóxicas, como metais e pesticidas organoclorados, em amostras de sedimento, água, folhas e raízes de três espécies de mangues nas áreas de manguezais dos complexos estuarinos da Baixada Santista e de Cananéia - São Paulo. O diagnóstico foi realizado em cinco pontos de cada uma destas regiões e as técnicas utilizadas para as análises foram a cromatografia gasosa com detector de captura eletrônica (GC-ECD) e a espectrometria de emissão atômica com fonte de plasma indutivamente acoplado (ICP-AES).

Os resultados obtidos demonstraram que, dentre os 10 metais estudados, apenas alguns pontos de coleta apresentaram valores de concentrações acima dos limites estabelecidos pelas legislações, entretanto, para os 18 compostos organoclorados determinados, foram obtidas concentrações acima dos limites de tolerância na maioria das amostras, indicando a necessidade de maior atenção das autoridades responsáveis, uma vez que estas não são substâncias naturais de manguezais ou até mesmo da fisiologia de plantas que habitam estes ecossistemas. 


\begin{abstract}
The mangrove, great nurseries of the nature that can be find in almost all the Brazilian coast, are areas that require the maximum protection against ambient riots. In the Baixada Santista and the region of Cananéia - Iguape, the fishing activity is the main subsidy for many families, however this have being affected in the last years by the indifference with these environments are treated. This so important ecosystem that contributes to the control of the climate of littoral cities and offers wood, drugs, oils and a rich variety of foods also holds back pollutants with much easiness, what it puts at risk even the vegetal or animal life, which includes the man.
\end{abstract}

Ahead this concern, this work aimed at to evaluate potentially toxic substances, as metals and organochlorine pesticides, in sediment samples, water, leaves and roots of three mangrove species in the Baixada Santista and Cananéia - São Paulo estuary complexes areas. The diagnosis was done in five points of each region and the techniques used for the analyses had been the gas chromatography with electron capture detector (GC-ECD) and the atomic emission spectrometry with inductively coupled plasma (ICP-AES).

The results obtained had demonstrated that amongst 10 studied metals, only some sample points had presented concentrations values above of the limits established by the legislation, however, for 18 determined organochlorine compounds, had been concentrations above of the tolerance limits in the samples majority, indicating the need of better attention of the responsible authorities, considering that these compounds are not natural substances of mangrove or even though of the plants physiology that inhabit these ecosystems. 


\section{SUMÁRIO}

1. INTRODUÇÃO__ 1

1.1 O Ecossistema Manguezais___ 1

$\begin{array}{ll}\text { 1.1.1 Os Sedimentos dos Manguezais___ } & 3\end{array}$

$\begin{array}{ll}\text { 1.1.2 A Floresta de Mangues___ } & 6\end{array}$

1.1.2.1 Mangue Vermelho ou Bravo (Rhizophora mangle)___ 8

1.1.2.2 Mangue Preto ou Siriúba (Avicennia schaueriana)___ 9

1.1.2.3 Mangue Branco ou Tinteira (Laguncularia racemosa)__ 10

$\begin{array}{lr}\text { 1.1.3 A Fauna dos Manguezais___ } & \mathbf{1 2}\end{array}$

$\begin{array}{ll}\text { 1.1.4 Manguezais do complexo estuarino da Baixada Santista___ } & \mathbf{1 3}\end{array}$

$\begin{array}{ll}\text { 1.1.5 Manguezais do complexo estuarino de Cananéia___ } & \mathbf{1 6}\end{array}$

2 FUNDAMENTOS TEÓRICOS___ 21

2.1 Substâncias Húmicas___ 21

2.2 Metais: Essencialidade e Toxicidade___ 25

$\begin{array}{lr}\text { 2.2.1 Alumínio }(\mathrm{Al}) \_ & \mathbf{2 7}\end{array}$

2.2.2 Cádmio $(C d) \_29$

$\begin{array}{lr}2.2 .3 \text { Chumbo }(\mathrm{Pb}) — & 30\end{array}$

$\begin{array}{ll}2.2 .4 \text { Cobalto }(\mathrm{Co}) \_ & 33\end{array}$

$\begin{array}{ll}2.2 .5 \text { Cobre }(\mathrm{Cu}) & 34\end{array}$

$\begin{array}{ll}2.2 .6 \mathrm{Cromo}(\mathrm{Cr}) \_ & 35\end{array}$

$\begin{array}{ll}2.2 .7 \text { Ferro }(\mathrm{Fe}) \_ & 36\end{array}$

$\begin{array}{ll}\text { 2.2.8 Manganês }(\mathrm{Mn}) \_ & 38\end{array}$

$\begin{array}{ll}2.2 .9 \mathrm{Niquel}(\mathrm{Ni}) \_ & \mathbf{4 0}\end{array}$

2.2.10 Zinco $(\mathrm{Zn}) \_\mathbf{4 1}$

2.3 Pesticidas Organoclorados__ $\quad 42$

$\begin{array}{ll}2.3 .1 \text { Ciclodienos__ } & \mathbf{4 6}\end{array}$

$\begin{array}{ll}\text { 2.3.2 DDT e Subprodutos___ } & \mathbf{4 8}\end{array}$

$\begin{array}{ll}\text { 2.3.3 Hexaclorociclohexano__ } & 49\end{array}$

3 OBJETIVOS__ 53

4 PARÂMETROS ESTUDADOS: FUNDAMENTOS E METODOLOGIAS___ $\mathbf{5 5}$

4.1 Amostragem__ 55

4.2 Limpeza da Vidraria de Laboratório___

4.3 Caracterização das amostras de água___ 59

4.3.1 Temperatura da água $(T) \_59$

$\begin{array}{ll}\text { 4.3.2 Salinidade da água }(S) \_ & \mathbf{6 0}\end{array}$

$\begin{array}{ll}\text { 4.3.3Potencial Hidrogeniônico da água }(\mathrm{pH}) \_ & \mathbf{6 1}\end{array}$

$\begin{array}{ll}\text { 4.3.4 Oxigênio Dissolvido na água (DO)__ } & 62\end{array}$

$\begin{array}{ll}4.3 .5 \text { Condutividade da água }(E C) \_ & 62\end{array}$

$\begin{array}{ll}\text { 4.3.6 Sólidos Totais Dissolvidos na água (TDS)__ } & 63\end{array}$

$\begin{array}{ll}4.4 \text { Caracterização das amostras de sedimento___ } & 64\end{array}$

4.4.1 Teor de Umidade no sedimento $(H) \_64$

$\begin{array}{ll}\text { 4.4.2 Potencial Hidrogeniônico do sedimento }(\mathrm{pH}) \_ & \mathbf{6 5}\end{array}$

$\begin{array}{ll}\text { 4.4.3 Teor de Matéria Orgânica no sedimento }(\mathrm{OM}) \_ & 65\end{array}$ 
4.4.4 Capacidade de Troca Catiônica do sedimento (CEC)

4.4.5 Teor de Carbono Orgânico Total no sedimento (TOC)___ $\quad 69$

$\begin{array}{ll}\text { 4.4.6 Teor de Ácidos Húmicos no sedimento (HA)___ } \quad \mathbf{7 0} & \mathbf{7 0}\end{array}$

$\begin{array}{ll}4.5 \text { Preparo de amostras para determinação de metais___ } & 70\end{array}$

4.5.1 Digestão Ácida de amostras de sedimento e raízes e folhas de mangues para a determinação de $\mathrm{Al}, \mathrm{Cd}, \mathrm{Pb}, \mathrm{Co}, \mathrm{Cu}, \mathrm{Cr}, \mathrm{Fe}, \mathrm{Mn}$, Ni e Zn

4.5.2 Digestão Ácida de amostras de água para a determinação de $\mathrm{Al}, \mathrm{Cd}, \mathrm{Pb}, \mathrm{Co}, \mathrm{Cu}$,

$\mathrm{Cr}, \mathrm{Fe}, \mathrm{Mn}$, Ni e Zn

4.6 Determinação de metais por ICP-AES

4.6.1 Espectrometria de Emissão Atômica com Fonte de Plasma Inductivamente Acoplado (ICP-AES)

4.6.2 Condições espectrométricas

4.6.3 Limite de Detecção e Limite de Quantificação___ 76

$\begin{array}{ll}\text { 4.6.4 Quantificação dos metais pseudo-totais___ } & \mathbf{7 6}\end{array}$

4.7 Preparo de amostras para a determinação de compostos organoclorados___ $\quad 77$

$\begin{array}{ll}\text { 4.7.1 Extração Soxhlet___ } & 77\end{array}$

4.7.2 Clean-up - Extração em Fase Sólida (SPE): isolamento da matriz___

4.8 Determinação de compostos organoclorados por $G C-E C D \_$
$\mathbf{8 0}$

$\begin{array}{ll}\text { 4.8.1 Cromatografia Gasosa (GC)__ } & \mathbf{8 0}\end{array}$

$\begin{array}{ll}\text { 4.8.2 Detector de Captura de Elétrons }(E C D) \_ & \mathbf{8 2}\end{array}$

$\begin{array}{ll}\text { 4.8.3 Condições Cromatográficas____ } & \mathbf{8 4}\end{array}$

4.8.4 Limite de Detecção e Limite de Quantificação___ $\quad 84$

$\begin{array}{lr}\text { 4.8.5 Avaliação do Método___ } & 85\end{array}$

$\begin{array}{lr}\text { 4.8.6 Quantificação dos compostos organoclorados__ } & 87\end{array}$

4.9 Destino dos Resíduos de Laboratório___ $\quad 88$

5 RESULTADOS_ $\quad 90$

$\begin{array}{ll}5.1 \text { Caracterização das amostras de água___ } & 90\end{array}$

5.2Caracterização das amostras de sedimento____ 93

5.3 Determinação de metais pseudo-totais em amostras de água, sedimento e folhas e raízes de mangues

5.4 Determinação de compostos organoclorados em amostras de sedimento e folhas e raízes de mangues 


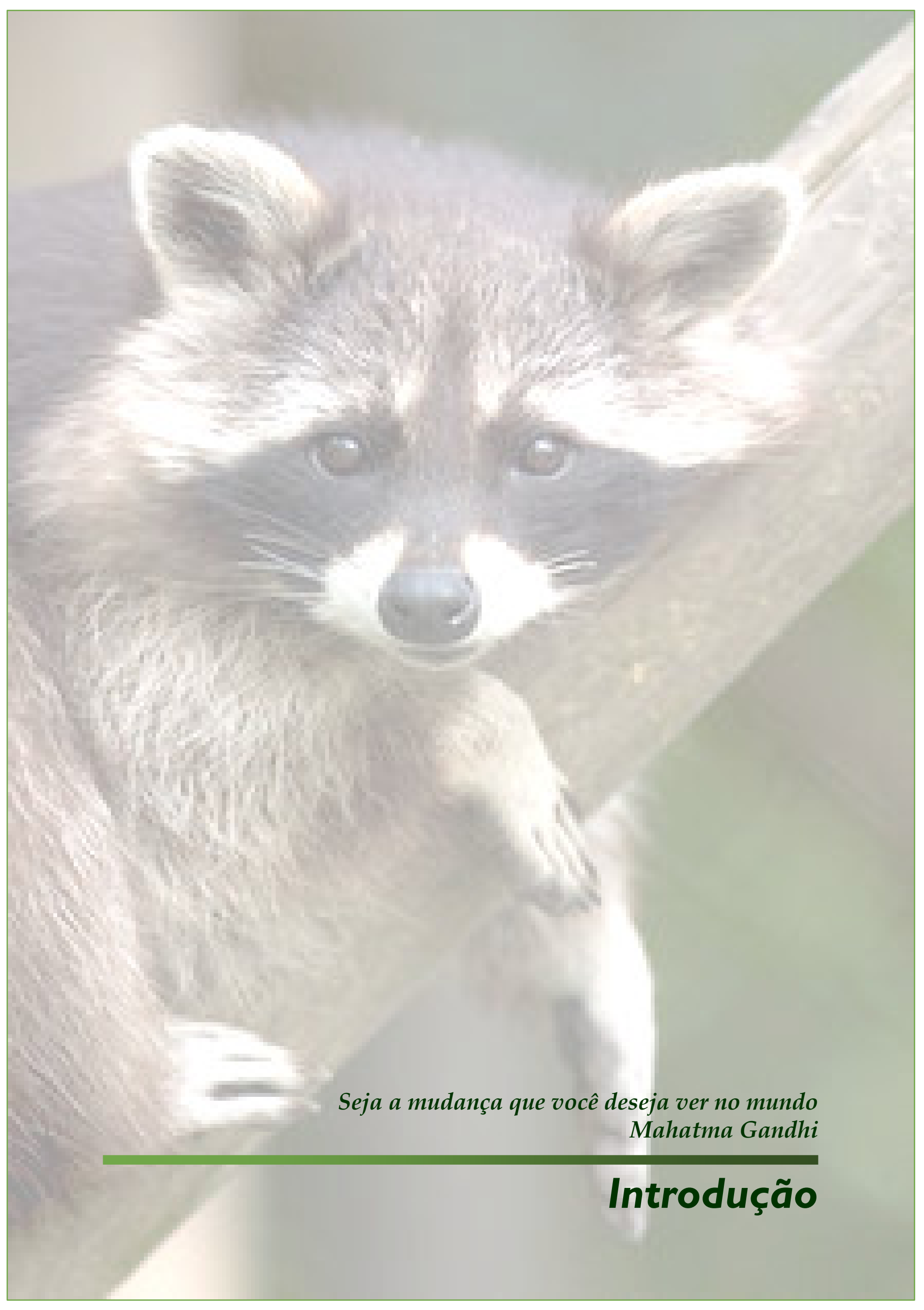




\section{INTRODUÇÃO}

\subsection{O Ecossistema Manguezais}

Os manguezais são ecossistemas costeiros que estão localizados na parte interna de baías junto à foz dos rios, em estuários protegidos das ondas sujeitos ao regime das marés, e que se desenvolvem nos litorais tropicais e subtropicais, unindo os ambientes marinho, terrestre e de água doce (SCHAEFFER-NOVELLI, 1995; LAMPARELLI, 1998).

Estes ecossistemas são áreas que regulam o fluxo dos mananciais hídricos, pois o escoamento dos rios é alternadamente represado ou liberado pelas marés e em conseqüência disso são criadas zonas alagadas, com variações de salinidade e periodicamente calmas, onde são depositados sedimentos finos. Assim, surgem ambientes bem especiais com flora e fauna adaptadas (SCHAEFFER-NOVELLI, 1995; LAMPARELLI, 1998; FIRME, 2003).

Quando utilizamos o termo mangue, nos referimos às diferentes espécies de árvores que se desenvolvem nestes ecossistemas, enquanto que o termo manguezal designa o conjunto destas espécies e seu ambiente, ou seja, a comunidade em si (VANNUCCI, 1999).

No Brasil, os manguezais são considerados um dos ambientes naturais mais produtivos, os quais se encontram entre as costas de Oiapoque (Amapá) e de Laguna (Santa Catarina), ocupando uma área de 10.000 a $25.000 \mathrm{~km}^{2}$ (YOKOYA, 1995). No estado de São Paulo estas áreas correspondem a 231 $\mathrm{km}^{2}$ (LAMPARELLI, 1998). Estes ambientes apresentam considerável acúmulo de material orgânico, o que tem grande valor para as águas estuarinas que recebem esses detritos. Tais detritos, que se encontram em suspensão nas águas, são compostos basicamente por fragmentos e folhas de mangues, e são a base alimentar de diversas espécies de caranguejos, camarões, moluscos e peixes (SCHAEFFER-NOVELLI, 1991).

Por sua natureza, os manguezais garantem excelentes condições de proteção, alimentação, crescimento e reprodução para diversas espécies, por 
isso são considerados grandes berçários da natureza. Além disso, os manguezais são de extrema importância para as populações locais, já que auxiliam no controle do clima e protegem as áreas de terra firme contra tempestades e erosões causadas pelas marés (LAMPARELLI, 1998).

Os manguezais ainda têm grande valor econômico, pois servem como fonte de renda para as comunidades locais. A pesca artesanal de peixes, camarões, caranguejos e moluscos é, muitas vezes, o principal subsídio para muitas famílias. Além da atividade pesqueira, também são áreas exploradas para extração de madeiras, remédios, álcool, óleos e tanino. Outras atividades incluem o turismo ecológico, navegação e educação ambiental (LAMPARELLI, 1998).

Fenômenos naturais como frentes atmosféricas, ventos fortes, inundações, fluxo das águas, erupções vulcânicas, marés extremas entre outros, podem causar alterações nas propriedades físicas, químicas e biológicas dos manguezais. Estes impactos, porém atuam como tensores agudos afetando os manguezais temporariamente, tornando quase sempre possível o restabelecimento da qualidade ambiental anterior. Por outro lado, alguns eventos induzidos pela ação humana, como acidentes de contaminação por vazamento de produtos tóxicos, atuam como tensores crônicos perpetuando sua ação e seus impactos em longo prazo, podendo inclusive provocar a morte do manguezal. Além do mais, a retirada de uma fonte poluidora de um local não implica necessariamente na interrupção imediata de seus impactos, uma vez que um determinado impacto pode desencadear 0 surgimento de outros, a longo prazo (VARJABEDIAN, 1995).

Embora sejam protegidos por lei, os manguezais são áreas seriamente afetadas pelo desenvolvimento econômico desordenado e pela expansão urbana com saneamento básico precário. São ambientes que retêm poluentes com facilidade e muitas vezes servem de alvo para lixões, aterros, marinas e obras de engenharia. O descaso com os manguezais é tão evidente, que muitas destas áreas foram aterradas simplesmente por serem consideradas "feias e sujas", sendo então "aproveitadas" para qualquer outra atividade esteticamente mais útil. Outras vezes, estas foram adaptadas para a 
agricultura, pecuária, cultivo de camarões entre outros, e abandonadas quando não serviam mais.

\subsubsection{Os Sedimentos dos Manguezais}

Em ecossistemas aquáticos, os sedimentos exercem um importante papel para a cadeia alimentar, pois estes são o habitat para as comunidades bentônica, de micróbios e macrofauna, as quais processam a matéria orgânica e servem de alimento para níveis tróficos superiores (CHAPMAN, 1990; MARIANI, 2006). Assim, os sedimentos contribuem como reservatórios para a bioacumulação e transferência de nutrientes, e o seu estudo não somente fornece informações sobre o estado momentâneo de contaminação, mas também um registro recente (sedimento superficial) e histórico (testemunhos) do ambiente aquático de onde é extraído, uma vez que suas camadas são depositadas subsequentemente (BURTON; LANDRUM, 2003; MOZETO, 2004; MARIANI, 2006).

Os sedimentos dos manguezais possuem características variáveis devido às suas diferentes origens. No entanto, de um modo geral, estes são predominantemente argilas e lamas argilo-arenosas com textura e composições químicas diferentes, onde cada espécie vegetal de mangue pode crescer, cada qual com sua preferência (VANNUCCI, 1999).

Nos manguezais, os movimentos exercidos pelas correntes de marés distribuem e compactam a maioria dos materiais depositados e, no processo de compactação, os sedimentos se tornam densos e com partículas bem unidas, restando pouco espaço intersticial e resultando em uma deficiência gradual de oxigênio, além de alcançar baixos valores para o pH do meio (VANNUCCI, 1999; FERREIRA, 2002). Estes sedimentos possuem coloração cinza na superfície e preta nas camadas internas, onde estão presentes milhares de bactérias anaeróbias que decompõem grande quantidade de matéria orgânica presente nestes ambientes (FIRME, 2003). 
Os manguezais são ecossistemas que variam muito quanto a sua composição e estrutura, uma vez que seus sedimentos são formados por partículas provenientes tanto do mar quanto do continente, de origem tanto orgânica quanto inorgânica, o que permite a estes ambientes alta diversidade e produtividade.

Fatores como temperatura, distribuição das chuvas, periodicidade das marés e a disposição e qualidade da matéria orgânica exercem efeito direto sobre o metabolismo dos sedimentos dos manguezais e, conseqüentemente, sobre suas condições biogeoquímicas. Dependendo de como e com que freqüência as alterações causadas por estes fatores ocorrem sobre as condições físico-químicas do meio, diferentes processos ligados a decomposição da matéria orgânica podem ocorrer nos sedimentos dos manguezais (PONNAMPERUMA, 1972; FERREIRA, 2002).

As freqüentes inundações das marés proporcionam aos sedimentos dos manguezais constantes mudanças nos valores de $\mathrm{pH}$, na capacidade de troca catiônica, no potencial redox, nas alterações no equilíbrio de minerais entre outros (PONNAMPERUMA, 1972; FERREIRA, 2002). Devido aos alagamentos, a taxa de difusão do oxigênio no solo pode ser reduzida em 10.000 vezes, tornando-se muito inferior à demanda microbiana para a oxidação da matéria orgânica. Assim, a decomposição desta é realizada por meio de microorganismos anaeróbios e outros receptores de elétrons que não $\mathrm{O}^{\mathrm{O}_{2}}$, seguindo a seguinte seqüência termodinâmica: $\mathrm{NO}_{3}{ }^{-}, \mathrm{Mn}_{4}{ }^{+}, \mathrm{Fe}_{3}{ }^{+}, \mathrm{SO}_{4}{ }^{2-}, \mathrm{CO}_{2}$ (metanogênese), $\mathrm{N}_{2}$ e H${ }^{+}$(FROELICH et al., 1979; SCHULZ, 2000; FERREIRA, 2002).

Estudos apontam que a combinação da alta concentração de matéria orgânica e enxofre com a condição anaeróbia, além de fontes de ferro reativo e a abundância do sulfato fornecido pela água do mar, permite aos solos dos manguezais um ambiente propício à redução bacteriana do sulfato. Neste processo, o sulfeto gerado precipita na forma de sulfeto de ferro, resultando no acúmulo de pirita $\left(\mathrm{FeS}_{2}\right)$. Nas etapas da piritização pode ou não ocorrer a formação de sulfetos de ferro menos estáveis, como a greigita $\left(\mathrm{Fe}_{3} \mathrm{~S}_{4}\right)$ e a mackinawita (FeS), que são sulfetos voláteis em meios ácidos. Porém, na 
ausência de ferro livre, o sulfeto gerado pode ainda se difundir para as camadas superficiais e ser re-oxidado a sulfato, através de uma cadeia química e biológica complexa que envolve elementos receptores de elétrons. Sendo assim, os compostos de ferro e enxofre cumprem papeis importantes nos ciclos biogeoquímicos de manguezais (HOWARTH; MERKEL, 1984; BREEMEN; BUURMAN, 1998; FERREIRA, 2005).

Entretanto, de acordo com a literatura, outros fatores podem ser responsáveis pelas variações físico-químicas nestes ambientes, como as atividades da flora e fauna. Alguns autores indicam que certas espécies de mangue são capazes de absorver oxigênio nas superfícies dos sedimentos e transportá-lo através de suas estruturas radiculares para sedimentos subsuperficiais, permitindo a difusão do mesmo e auxiliando nas variações redox (MCKEE, 1993; MCKEE; MENDELSSOHN; HESTER, 1988; FERREIRA, 2005). A atividade da fauna também exerce papel importante, uma vez que algumas espécies de caranguejos constroem galerias em busca de alimentos na superfície, transportando a matéria orgânica não decomposta para as camadas mais profundas e transferindo os compostos reduzidos para as regiões oxidantes (HINES; JONES, 1985; FERREIRA, 2005). Assim, as atividades da flora e fauna podem alterar a dinâmica de elementos sensíveis às mudanças nas condições redox, como por exemplo, as concentrações de ferro e enxofre que podem diminuir ou aumentar nas águas intersticiais e nas diversas frações da fase sólida (HINES et al., 1984; FERREIRA, 2005).

Na respiração subóxida, a redução de óxidos e oxidróxidos de ferro, anterior à redução do sulfato, predomina na decomposição da matéria orgânica, gerando altas concentrações de cátions $\mathrm{Fe}^{2+}$ para as águas intersticiais que precipitam sob a forma de carbonatos, fosfatos e sulfetos, podendo sofrer nova oxidação a ferrihidrita, lepidocrocita e goetita (CANFIELD; THAMDRUP; HANSEN, 1993; FERREIRA, 2005). No entanto, sob condições óxicas, ou seja, em processos aeróbios, a mineralização da matéria orgânica ocorre na presença de oxigênio, o que promove a oxidação das frações piríticas e de sulfetos voláteis em meios ácidos, além de uma drástica 
diminuição nos valores de $\mathrm{pH}$ do meio pela produção de ácido sulfúrico, como pode ser observado nas equações 1 e 2 (FERNANDES; PERIA, 1995).

$$
\begin{aligned}
& \mathrm{FeS}_{2}+\mathrm{H}_{2} \mathrm{O}+31 / 2 \mathrm{O}_{2} \longrightarrow \mathrm{FeSO}_{4}+\mathrm{H}_{2} \mathrm{SO}_{4} \\
& \text { sulfeto de ferro sulfato de ferro ácido sulfúrico } \\
& \mathrm{Fe}_{2}\left(\mathrm{SO}_{4}\right)_{3}+6 \mathrm{H}_{2} \mathrm{O} \longrightarrow 2 \mathrm{Fe}(\mathrm{OH})_{3}+\mathrm{H}_{2} \mathrm{SO}_{4} \\
& \text { sulfato de ferro hidróxido de ferro ácido sulfúrico }
\end{aligned}
$$

De acordo com alguns autores, as frações piríticas e de sulfetos voláteis em meios ácidos possuem certa capacidade de controlar a biodisponibilidade de traços de metais nos manguezais, fixando-os nos sedimentos e impedindo a sua propagação em condições anóxicas, indicando que o conhecimento detalhado da biogeoquímica de ferro e enxofre nestes ambientes pode ser relevante (DI TORO et al., 1992; COOPER; MORSE, 1998; LEE et al., 2000; OTERO; MACÍAS, 2002; FERREIRA, 2005).

\subsubsection{A Floresta de Mangues}

Nos manguezais, o recém-chegado depara, antes de mais nada, com a floresta. É grandiosa, única e maravilhosa. Não há, como nas outras florestas, chão sobre o qual andar. Durante a maré-cheia, a floresta está inundada e quando a maré recua, deixa atrás de si um emaranhado caótico de raízes de todo tipo, que alcançam até dois ou três metros de altura; troncos mais ou menos recobertos por mucilagem, liquens e algas que crescem também sobre os galhos e emergem do lodo, onde é possível afundar-se até os joelhos, se houver espaço suficiente para apoiar os pés.

A beleza inesquecível da floresta (...) é devida à harmonia e ordem dos troncos e das copas que emergem da 
desordem das raízes aéreas e raízes-escora, enquanto o todo é envolto num silêncio profundo. Impera um tal senso de lei de ordem e calma, eficiência que nós, seres humanos intrusos, instintivamente passamos a falar em voz baixa, com admiração e respeito.

A calma e o silêncio são tão tangíveis nas florestas de mangues completamente desenvolvidas que se ouve até 0 pequeno "puf" das bolhas de metano que vêm do fundo da água estourar, pipocando, na superfície. A própria água respeita o silêncio geral, ao fluir por igual nos fluxos laminados da enchente e da vazante. (VANNUCCI, 1999, p.33-34).

Uma cobertura vegetal estabelecida por um grupo de espécies adaptadas a terrenos lodosos, alagados e de alta salinidade, representa 0 manguezal. A presença de raízes-escora, que se originam nos troncos e alcançam o solo formando arcos, permite a fixação e sustentação das árvores de mangue no solo frouxo. A deficiência de oxigênio se deve ao constante encharcamento dos manguezais, porém algumas árvores possuem em suas raízes respiratórias aéreas, pneumatóforos que emergem do solo com pequenas estruturas, as lenticelas, que permitem a troca de gases, como o oxigênio e o gás carbônico, com o meio. A salinidade também é um fator limitante para a maioria das plantas, contudo, para as plantas de mangue, este fator se torna positivo, uma vez que diminui a competição, pois os mangues apresentam mecanismos que lhes permitem suportar tal condição (SCHAEFFER-NOVELLI, 1991).

Dentre as espécies de mangue que habitam os manguezais do estado de São Paulo, as principais são plantas de porte arbóreo, dentre as quais se destacam: o mangue vermelho ou bravo (Rhizophora mangle), o mangue preto ou de siriúba (Avicennia schaueriana) e o mangue branco ou tinteira (Laguncularia racemosa), além de uma variedade de vegetais como bromélias, samambaia do mangue, gramínea spartina, liquens e algas. 


\subsubsection{Mangue Vermelho ou Bravo (Rhizophora mangle)}

O mangue vermelho (figura 1a e figura 2) é o mangue mais conhecido ao longo do litoral brasileiro. É uma espécie arbórea que possui copa arredondada e forma bosques com estaturas que variam de 5 a $30 \mathrm{~m}$ de altura. Floresce entre os meses de dezembro e janeiro, possui inúmeras ramificações e pertence à Classe Dicotyledoneae, ordem Myrtiflorae e família Rhizophoraceae. Estas árvores são mais abundantes nas embocaduras de rios e baías interiores, em contato com o mar, onde podem ser vistas facilmente a longas distâncias devido às suas exóticas raízes-escora (SCHAEFFERNOVELLI, 1991; SUGIYAMA, 1995).

O mangue bravo, como também é chamado, possui a casca lisa e clara e é rico em tanino (substância de cor vermelha e impermeabilizante), o que dá um aspecto avermelhado ao seu caule. A estrutura reprodutiva (vivípara) desta espécie é realizada através do desprendimento de propágulos maduros da árvore mãe que caem como lanças apontadas para baixo, fixando-se na lama na maré baixa, podendo ser viáveis por doze meses (SCHAEFFER-NOVELLI, 1991; SUGIYAMA, 1995).

O mangue bravo é o gênero menos tolerante à presença de sal, no entanto, pode suportar longos períodos de alagamentos. Seu sistema radicular é formado por raízes chamadas rizóforos, que apresentam características peculiares como, por exemplo, os arcos que se originam no meio dos troncos e ramos e alcançam a lama, sustentando e diferenciando esta espécie (SCHAEFFER-NOVELLI, 1991; SUGIYAMA, 1995; FERNANDES; PERIA, 1995). Além disso, os rizóforos possuem membranas permeáveis que filtram a água, impedindo assim, a passagem do sal para o interior da planta, tornando esta espécie resistente à água salgada e fazendo com que ela tolere salinidade de até 55 partes de sal por 1000 partes de água, apesar de apresentar melhor crescimento quando esse valor não ultrapassa 35 partes por 1000 (FERNANDES; PERIA, 1995; SCHAEFFER-NOVELLI; CINTRÓN, 1986; SCHAEFFER-NOVELLI; LACERDA, 1994; FRUEHALF, 2005). 


\subsubsection{Mangue Preto ou de Siriúba (Avicennia schaueriana)}

O mangue preto (figura $1 \mathrm{~b}$ e figura 2) pertence à Classe Dicotyledoneae, ordem Tubiflorae e família Verbenaceae. Esta espécie possui aspecto arbóreo e constitui bosques com estaturas que variam de 6 a $25 \mathrm{~m}$ de altura, podendo ter ainda, mais ramificações caulinares finas. Seu florescimento ocorre no período de fevereiro a março e, em sua maioria, localiza-se na parte protegida do manguezal, próxima à interface entre a terra e a água. Suas folhas constituem ápices arredondados e tons esbranquiçados por baixo, devido à presença de pequenas escamas. Sua casca é lisa e possui coloração castanho-claro, porém quando raspada, se mostra amarelada (SCHAEFFERNOVELLI, 1991; SUGIYAMA, 1995; SCHAEFFER-NOVELLI; LACERDA, 1994; FRUEHALF, 2005).

A principal característica do mangue preto ou de siriúba é ter alta resistência à água salgada, uma vez que este possui glândulas capazes de expelir o excesso de sal absorvido através das folhas, tornando esta espécie de mangue a de maior capacidade de sobrevivência em locais com alta salinidade, suportando concentrações de 65 a 90 partes de sal por 1000 partes de água. Em sua reprodução vivípara, as sementes podem manter o potencial germinativo por até três meses, flutuando na água até encontrar lugar apropriado para se desenvolver (SCHAEFFER-NOVELLI, 1991; SCHAEFFERNOVELLI; LACERDA, 1994; FRUEHALF, 2005).

O sistema radicular do mangue preto consiste em diversas ramificações horizontais que alcançam até $5 \mathrm{~m}$ de comprimento e não mais que 0,5 $\mathrm{m}$ de profundidade. Destes ramos, emergem pequenas raízes em formas cônicas, geotropicamente negativas, com 20 a $30 \mathrm{~cm}$ de altura, chamadas pneumatóforos. Os pneumatóforos são de consistência esponjosa e são providos de pequenas estruturas, as lenticelas, que contém um grande número de espaços intercelulares capazes de armazenar ar e realizar a troca de oxigênio com o meio (SUGIYAMA, 1995; SCHAEFFER-NOVELLI; LACERDA, 1994; FRUEHALF, 2005). 


\subsubsection{Mangue Branco ou Tinteira (Laguncularia racemosa)}

O mangue branco (figura 1c e figura 2) é encontrado com mais freqüência em costas com baixas salinidades, preferindo áreas menos alagadas. Esta espécie pertence à Classe Dicotyledoneae, ordem Myrtiflorae e família Combretaceae (SCHAEFFER-NOVELLI, 1991).

A árvore ou arbusto do mangue branco possui copa arredondada bem como o mangue vermelho, porém difere das outras espécies de mangue por apresentar menor porte, uma vez que esta constitui bosques de 2 a $8 \mathrm{~m}$ de altura. Seu florescimento ocorre entre janeiro e fevereiro de cada ano e suas folhas são estreitas, com pecíolos vermelhos e ápices pontiagudos. Este mangue é o mais utilizado pelo caranguejo-uçá, para o cultivo de fungos e para os microorganismos, depois do apodrecimento das folhas nos interiores das tocas (SCHAEFFER-NOVELLI, 1991; SUGIYAMA, 1995; SCHAEFFERNOVELLI; CINTRÓN, 1986).

Assim como nos outros gêneros, o sistema reprodutivo do mangue branco ocorre através de propágulos e sementes, que podem germinar em até trinta dias. Seu sistema radicular é semelhante ao do mangue preto, porém pouco profundo, não ultrapassando $30 \mathrm{~cm}$ nos sedimentos. Este gênero também possui pneumatóforos, porém estes são bifurcados ou trifurcados, menos desenvolvidos e em menor quantidade com relação ao mangue preto (SUGIYAMA, 1995; SCHAEFFER-NOVELLI; CINTRÓN, 1986; SCHAEFFERNOVELLI; LACERDA, 1994; FRUEHALF, 2005). 


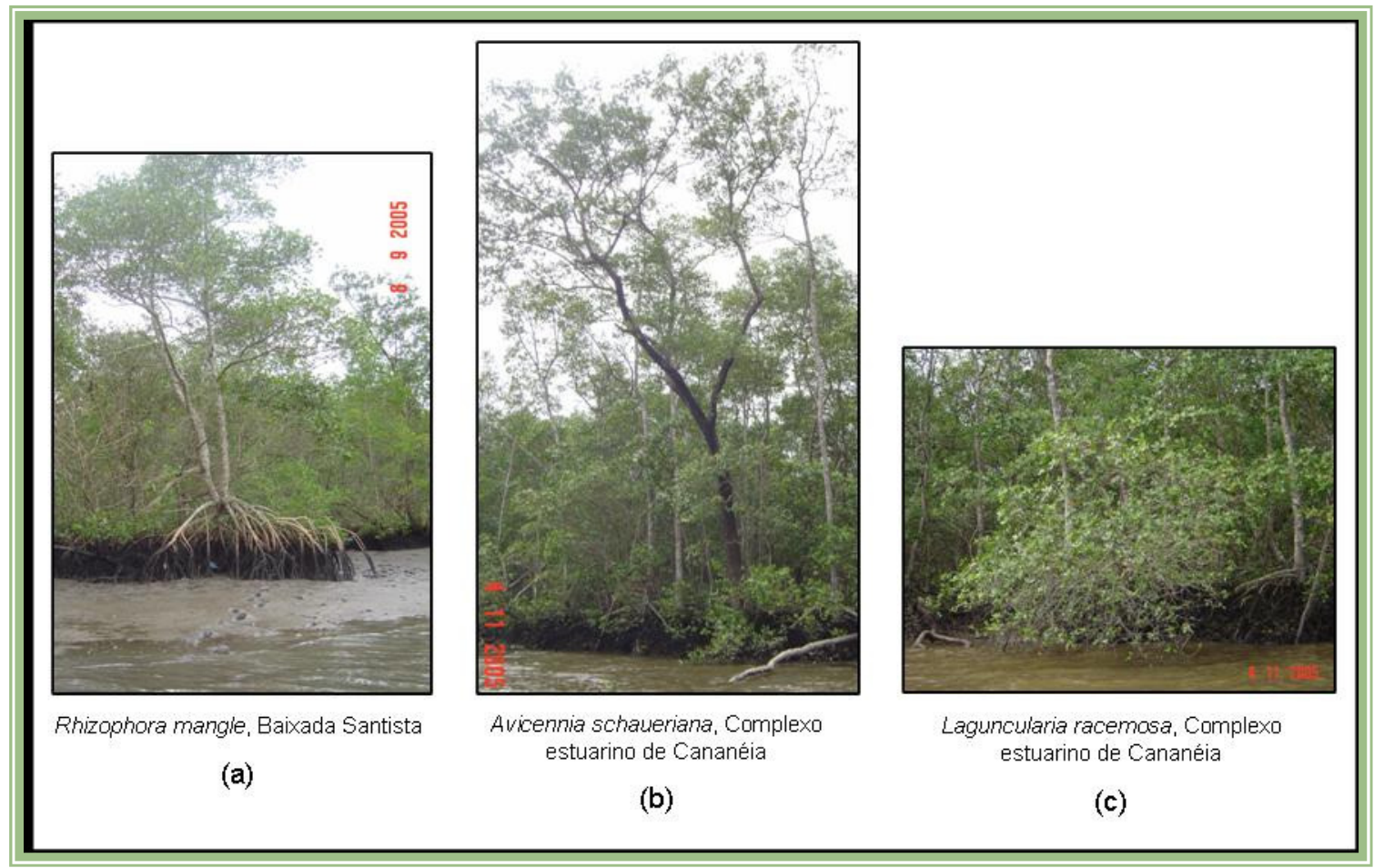

Figura 1: Espécies de mangue mais freqüentes nos manguezais do estado de São Paulo.

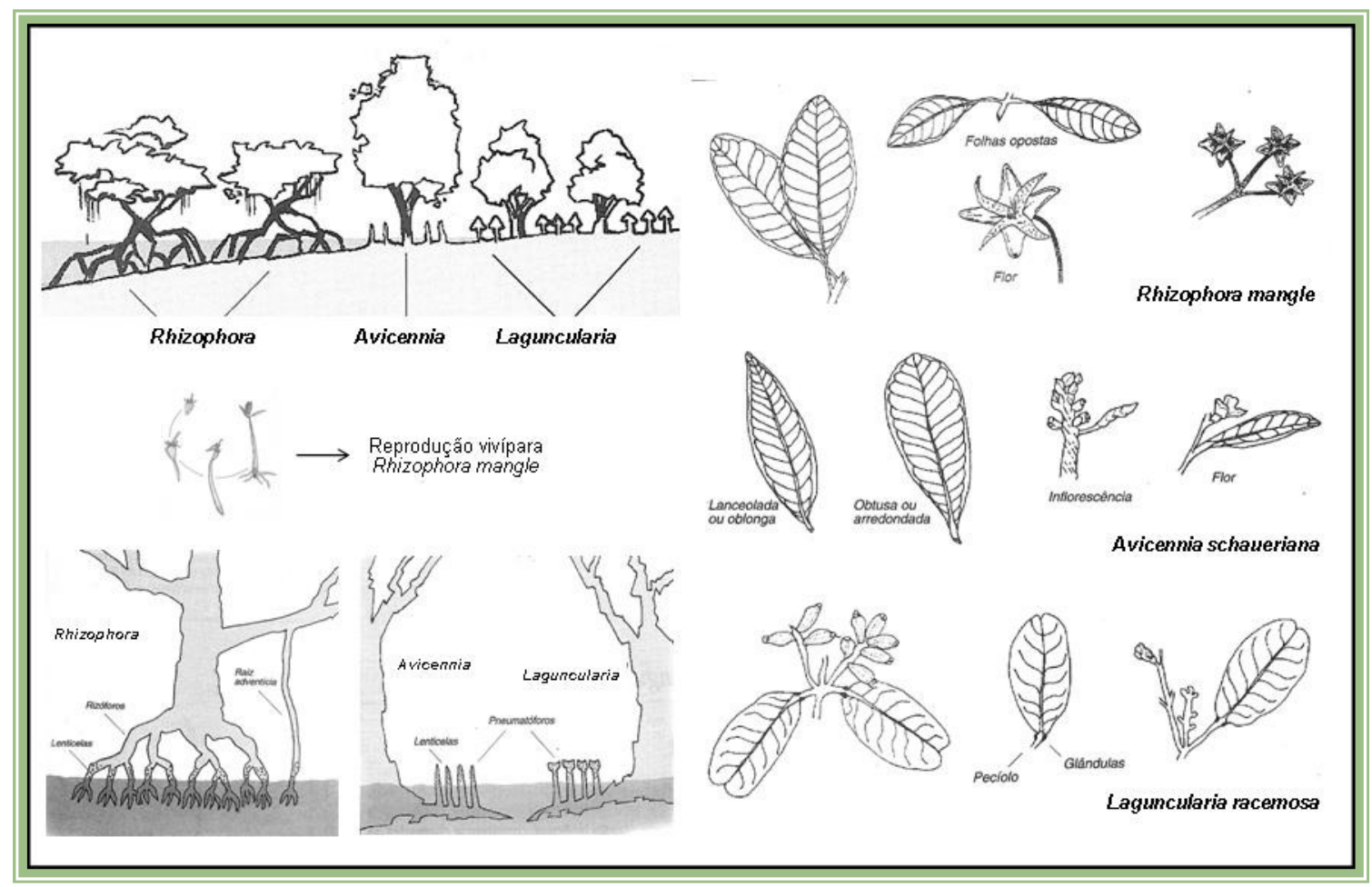

Figura 2: Características das espécies de mangue mais freqüentes nos manguezais do estado de São Paulo (adaptação de SCHAEFFER-NOVELLI, 1995). 


\subsubsection{A Fauna dos Manguezais}

Os ecossistemas de mangues são habitados por diversos animais, desde formas microscópicas até grandes peixes, aves, répteis e mamíferos. Diversas espécies originárias dos ambientes terrestre, marinho e de água doce, permanecem nos manguezais toda sua vida como residentes, semi-residentes, visitantes regulares ou oportunistas (SUGIYAMA, 1995).

Dentre os crustáceos, grupo animal característico do manguezal, destacam-se várias espécies de caranguejos, siris e camarões que formam enormes populações nos fundos lodosos. As ostras, mexilhões, berbigões e cracas se alimentam filtrando da água os pequenos fragmentos de detritos vegetais, ricos em bactérias. Há também espécies de moluscos que perfuram a madeira dos troncos de árvores, construindo ali os seus tubos calcários e se alimentando de microrganismos que decompõem a lignina dos troncos, auxiliando a renovação natural do ecossistema pela queda de árvores velhas e perfuradas (LAMPARELLI, 1998; LEITÃO, 1995; POR, 1984).

Além das espécies residentes, muitos peixes do litoral brasileiro dependem do manguezal para se alimentar, como tainhas, bagres, carapebas, robalos, tilápia-do-Nilo e manjubas. Esta variedade de peixes ainda atrai predadores como algumas espécies de tubarões, cações e golfinhos. Em alguns manguezais também podem ser encontrados eventualmente o jacaré de papo amarelo e o sapo Bufo marinus. Existe ainda uma pequena variedade de aves que se alimentam de peixes, crustáceos e moluscos, especialmente na maré baixa, quando os fundos lodosos estão expostos. Entre as aves aquáticas, ainda é possível encontrar os guarás (Eudocimus ruber), que estão entre as espécies consideradas ameaçadas de extinção. Dos mamíferos, podem ser citados o coati que é especialista em alimentar-se de caranguejos, a lontra que é hábil pescadora e o guaxinim que encanta com seus olhos mascarados. (LAMPARELLI, 1998; LEITÃO, 1995; POR, 1984). 


\subsubsection{Manguezais do complexo estuarino da Baixada Santista}

São 16 os municípios litorâneos do Estado de São Paulo, sendo a Baixada Santista constituída por nove deles: Bertioga, Guarujá, Cubatão, Santos, São Vicente, Praia Grande, Mongaguá, Itanhaém e Peruíbe.

Os manguezais da Baixada Santista representam $52 \%$ dos 231,22 km² de manguezais da costa paulista (Figura 3 e 4), dos quais se encontram divididos entre seus municípios conforme a Tabela 1 (LAMPARELLI, 1998). Fotografias aéreas tiradas entre os anos de 1958 e 1989 mostraram que 44 \% desses manguezais originalmente existentes encontravam-se degradados e 16 \% haviam sido aterrados para ocupação urbana ou industrial, restando apenas 40 \% em bom estado de conservação, sendo que a maior parte localiza-se na região de Bertioga (CETESB, 2001a).

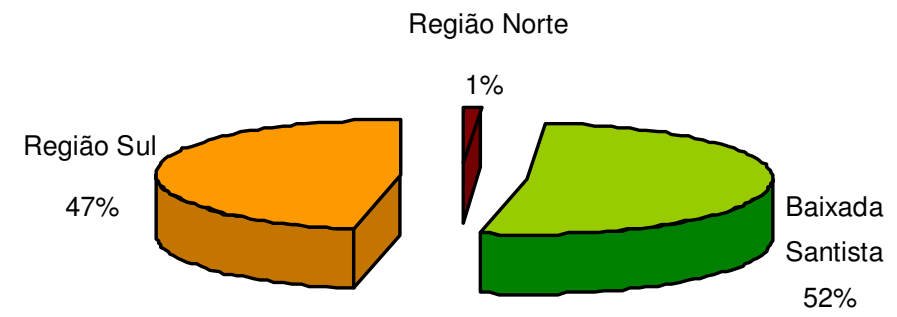

Figura 3: Distribuição da área de ocupação dos manguezais, por região, no estado de São Paulo.

Tabela 1: Área de manguezais por município da Baixada Santista.

\begin{tabular}{|ccc|}
\hline Município & $\begin{array}{c}\text { Área de } \\
\text { Manguezal } \\
\mathbf{( k m}^{\mathbf{2}} \mathbf{)}\end{array}$ & $\begin{array}{c}\text { Área de } \\
\text { Manguezal/município } \\
\mathbf{( \% )}\end{array}$ \\
\hline Bertioga & 18,31 & 15,23 \\
\hline Santos & 30,69 & 25,53 \\
\hline Guaruiá & 15,00 & 12,48 \\
\hline Cubatão & 23,00 & 19,13 \\
\hline São Vicente & 16,00 & 13,31 \\
\hline Praia Grande & 8,00 & 6,66 \\
\hline Mongaguá & 0,00 & 0,00 \\
\hline Itanhaém & 3,75 & 3,12 \\
\hline Peruíbe & 5,46 & 4,54 \\
\hline Total & $\mathbf{1 2 0 , 2 1}$ & $\mathbf{1 0 0 , 0 0}$ \\
\hline
\end{tabular}




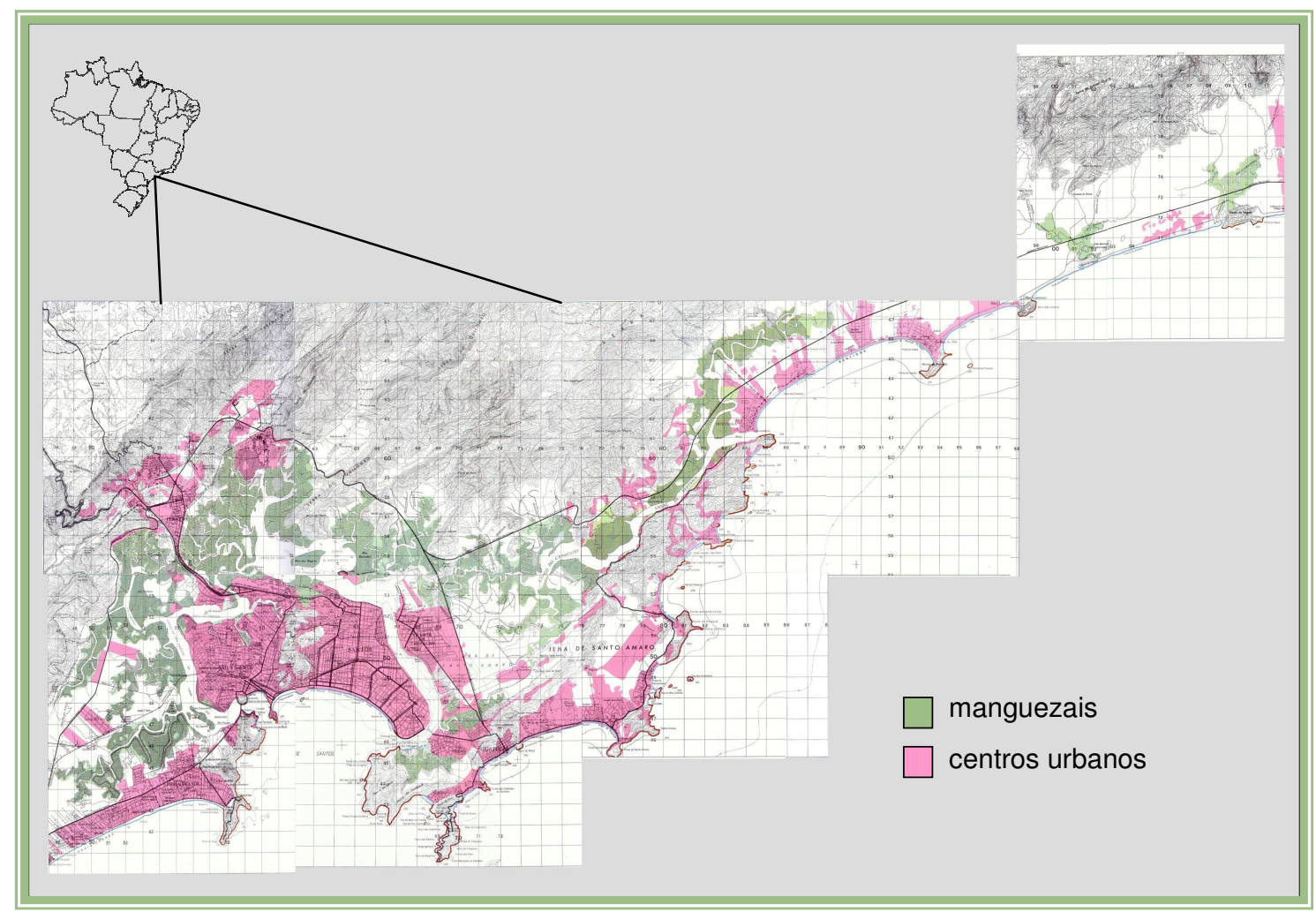

Figura 4: Mapeamento das áreas correspondentes a manguezais de parte da Baixada Santista (adaptado de LAMPARELLI, 1998).

A flora e fauna dos manguezais na Baixada Santista são enriquecidas pelos grandes bancos de lodo que a região possui. Pode-se encontrar uma intensa variedade de crustáceos e moluscos, o que atrai muitas espécies de aves aquáticas. No entanto, esses manguezais possuem ao seu redor um dos maiores centros urbanos do país, estando sujeitos a muitas variações ambientais provocadas tanto por poluentes provenientes do pólo industrial de Cubatão, quanto pelos impactos causados pela região portuária de Santos ou outras cidades como São Vicente. Apesar desses manguezais não se encontrarem em bom estado de preservação, exercem importantes funções atuando como filtros biológicos, retendo sedimentos e metais pesados, diminuindo a intensidade de assoreamento de rios e canais, bem como de contaminação da região costeira (LAMPARELLI, 1998).

A partir da década de 50 , diversas indústrias siderúrgicas, petroquímicas e de fertilizantes foram implantadas em meio aos canais estuarinos e 
manguezais da Baixada Santista. Esta atividade industrial, de alto potencial poluidor, fez dos estuários de Santos e São Vicente grandes receptores de resíduos tóxicos e efluentes líquidos contaminados. Os poluentes industriais, juntamente com os resíduos e esgotos do Porto de Santos e das cidades da região, provocaram um grave quadro de degradação ambiental, com significativos reflexos na área social e de saúde pública. Esse cenário foi agravado, ainda, pela disposição de resíduos sólidos industriais e domésticos em locais impróprios, além dos freqüentes acidentes com derramamentos de óleo e outras substâncias tóxicas nos cursos d'água (CETESB, 2001a).

Em meados de 1983, a Companhia de Tecnologia de Saneamento Ambiental (CETESB) juntamente com a prefeitura de Cubatão e as indústrias da região, criaram o "Projeto Cubatão", o qual tratava de um programa de controle de poluição ambiental, que somente teve início em 1985. Entretanto, estudos realizados pela CETESB em 1988, mostraram que alguns rios da região ainda estavam seriamente impactados por concentrações elevadas de metais pesados e compostos organoclorados na água, nos sedimentos e nos organismos aquáticos: peixes, siris e caranguejos (CETESB, 2001a).

Durante a década de 90, deu-se continuidade à implantação e aperfeiçoamento dos sistemas de controle da poluição das águas e do solo na região. Algumas indústrias implantaram sistemas para recirculação total dos efluentes líquidos ou aumentaram consideravelmente a reutilização de suas águas. Em locais contaminados por hidrocarbonetos e resíduos de organoclorados, foram implantados sistemas de coleta e tratamento das águas subterrâneas com a finalidade de descontaminar o solo e, até mesmo, eliminar a entrada de poluentes para o sistema hídrico. Assim como ocorreu a melhoria da qualidade das águas com as ações de controle, observou-se uma recuperação substancial dos manguezais e o aumento da diversidade de aves aquáticas, entre as quais os guarás, que podem ser vistos com alguma sorte (CETESB, 2001a).

Em 1993, deu-se início a um projeto de recuperação dos manguezais, através do plantio de espécies de mangue em áreas do município de Cubatão, que contou com a participação dos pescadores ribeirinhos e seus filhos. Os 
resultados demonstraram uma alta taxa de sobrevivência das espécies (cerca de $80 \%$ ), verificando-se, por conseguinte, a viabilidade da recuperação desse ecossistema na região (CETESB, 2001a).

A poluição dos manguezais e estuários da Baixada Santista é basicamente, nesse caso, proveniente de esgotos domésticos, aterros sanitários inadequados, terminais do porto e, principalmente, de fontes industriais. Portanto, a diversidade e volume de poluentes lançados são grandes, o que requer maior preocupação para com esse importante ecossistema.

\subsubsection{Manguezais do complexo estuarino de Cananéia}

O Litoral Sul do Estado de São Paulo inclui os municípios de Iguape, Ilha Comprida e Cananéia. Estes municípios abrangem $47 \%$ dos manguezais da costa paulista (Figura 3 e 5), dos quais se encontram divididos conforme a Tabela 2 (LAMPARELLI, 1998).

Tabela 2: Área de manguezais por município do Litoral Sul do estado de São Paulo.

\begin{tabular}{|ccc|}
\hline Município & $\begin{array}{c}\text { Área de } \\
\text { Manguezal } \\
\left.\mathbf{( k m}^{2}\right)\end{array}$ & $\begin{array}{c}\text { Área de } \\
\text { Manguezal/município } \\
(\%)\end{array}$ \\
\hline Iquape & 19,24 & 17,88 \\
\hline Ilha Comprida & 13,84 & 12,86 \\
\hline Cananéia & 74,54 & 69,26 \\
\hline Total & $\mathbf{1 0 7 , 6 2}$ & $\mathbf{1 0 0 , 0 0}$ \\
\hline
\end{tabular}

Localizado ao extremo sul, o município de Cananéia integra o Complexo Estuarino-Lagunar de Iguape-SP, Cananéia-SP e Paranaguá-PR. O complexo estuarino de Cananéia-Iguape faz parte da Área de Proteção Ambiental (APA) de Cananéia-Iguape-Peruíbe, que está sob responsabilidade do governo federal. O sistema possui quatro ilhas principais (Cananéia, Iguape, Comprida 
e Cardoso) que se encontram separadas por canais lagunares e rios que se comunicam com o Oceano Atlântico.

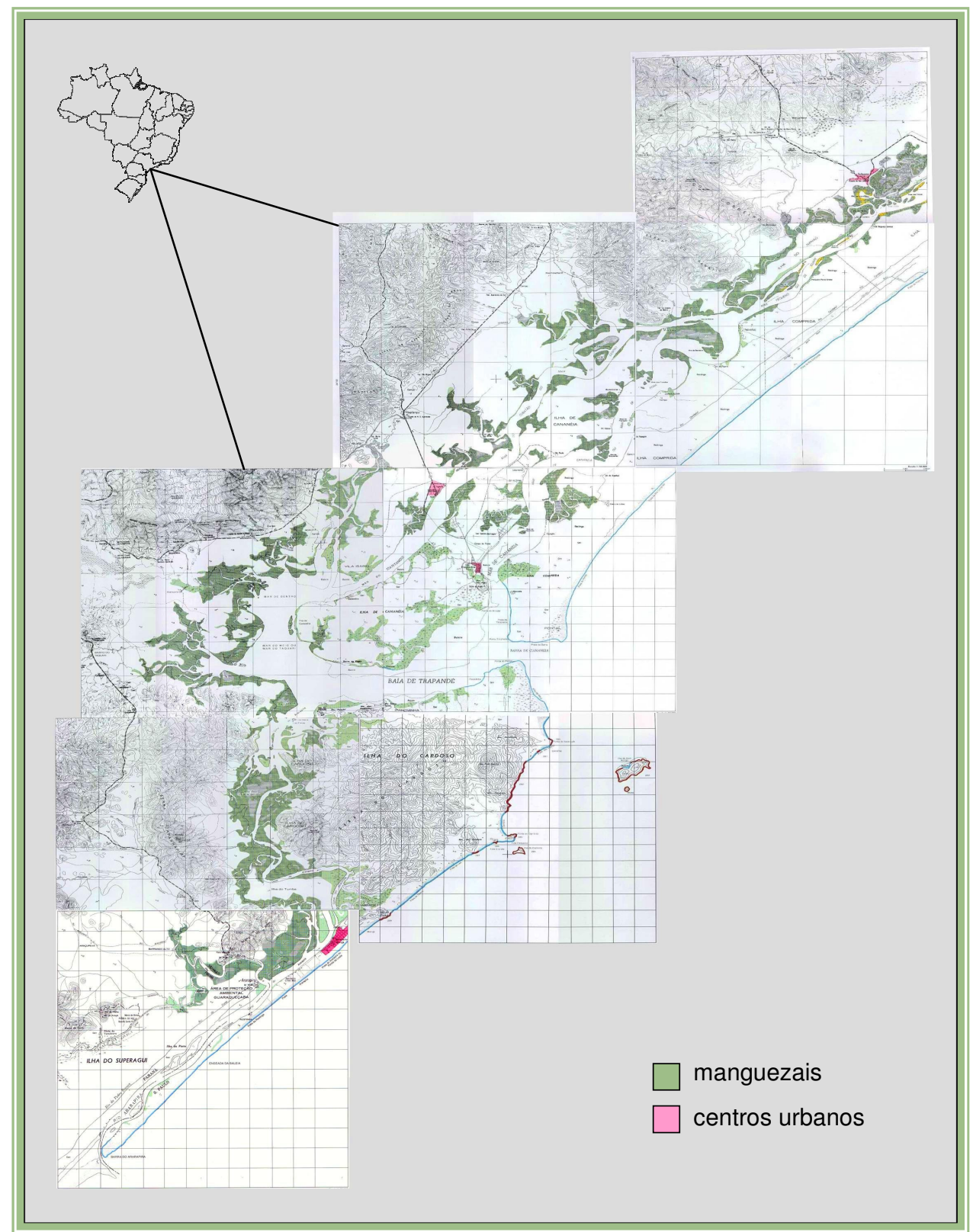

Figura 5: Mapeamento das áreas correspondentes a manguezais de parte do Complexo Estuarino de Cananéia-Iguape (adaptado de LAMPARELLI, 1998).

No ano de 1827, um canal nomeado Valo Grande foi aberto entre o Rio Ribeira de Iguape e o Mar Pequeno, o que resultou em grandes prejuízos para 
as condições de navegabilidade do complexo e modificações na ecologia da região. Como decorrência da abertura do Valo Grande e somando a areia trazida pelo Rio Ribeira de Iguape, a Ilha Comprida sofreu um aumento em suas dimensões e foi formada assim a llha de lguape, uma ilha artificial. Posteriormente, em 1978, o Valo Grande foi fechado, o que acarretou em mais mudanças no ecossistema e no interesse de mais estudos dessas áreas com o objetivo de detectar os impactos causados por estes acontecimentos (SCHMIDT, 1988).

Diferentemente da Baixada Santista, o complexo estuarino de CananéiaIguape está situado distante dos grandes centros urbanos e inserido em uma região de baixa densidade populacional, que apresentou, contudo, uma das maiores taxas de crescimento entre os anos de 1996 a 2000, 17,8 \% (CETESB, 2004a). Em função do pequeno desenvolvimento urbano e industrial, a região é uma das mais pobres do estado de São Paulo, porém apresenta uma das áreas de Mata Atlântica e os manguezais mais preservados do país (LAMPARELLI, 1998).

$\mathrm{Na}$ região de Cananéia-Iguape, a atividade pesqueira é intensa e depende diretamente das áreas de mangues. Os rios que percorrem a extensa planície costeira e deságuam no estuário contribuem com os nutrientes, que utilizados pelas plantas de mangue, formam a base da cadeia alimentar e enriquecem a região. Os manguezais do complexo estuarino de CananéiaIguape são ricos em crustáceos, peixes e moluscos, onde se destaca a ostra de mangue, que é o principal subsídio para os pescadores locais. A expressiva biodiversidade da região conta com espécies raras e/ou ameaçadas de extinção, como o papagaio-da-cara-roxa, o mono-carvoeiro, a onça pintada, o jacaré-do-papo-amarelo e o boto-cinza.

Apesar de ter os manguezais mais preservados do país, a região de Cananéia sofre com a falta de infra-estrutura para o tratamento de esgotos que são despejados in natura nos rios. Segundo o relatório anual de balneabilidade das praias, elaborado pela CETESB (2004a), o Rio Ribeira de Iguape, que é o maior rio paulista que flui diretamente para o Oceano Atlântico, recebe grande carga poluidora de esgotos sem tratamento. O sistema lagunar-estuarino também conta com a contaminação por metais pesados e outros agentes tóxicos, decorrentes da mineração na região do Vale do Ribeira (LAMPARELLI, 
1998). Além disso, a região possui áreas marcadas pela agricultura, onde o uso de pesticidas organoclorados foi largamente empregado, tanto na própria agricultura como nas campanhas contra doenças transmitidas por insetos (ALMEIDA, 1995; YOGUI, 2002).

Desta forma, diante de diferentes fontes potencialmente poluidoras e o aumento de uma ocupação desordenada, os $47 \%$ de manguezais do estado de São Paulo, encontram-se ameaçados e a degradação desses ecossistemas representa uma enorme perda na qualidade e na disponibilidade dos recursos pesqueiros, bem como de suas funções ecológicas, além de comprometer a biodiversidade, ou seja, o banco genético (LAMPARELLI, 1998). 


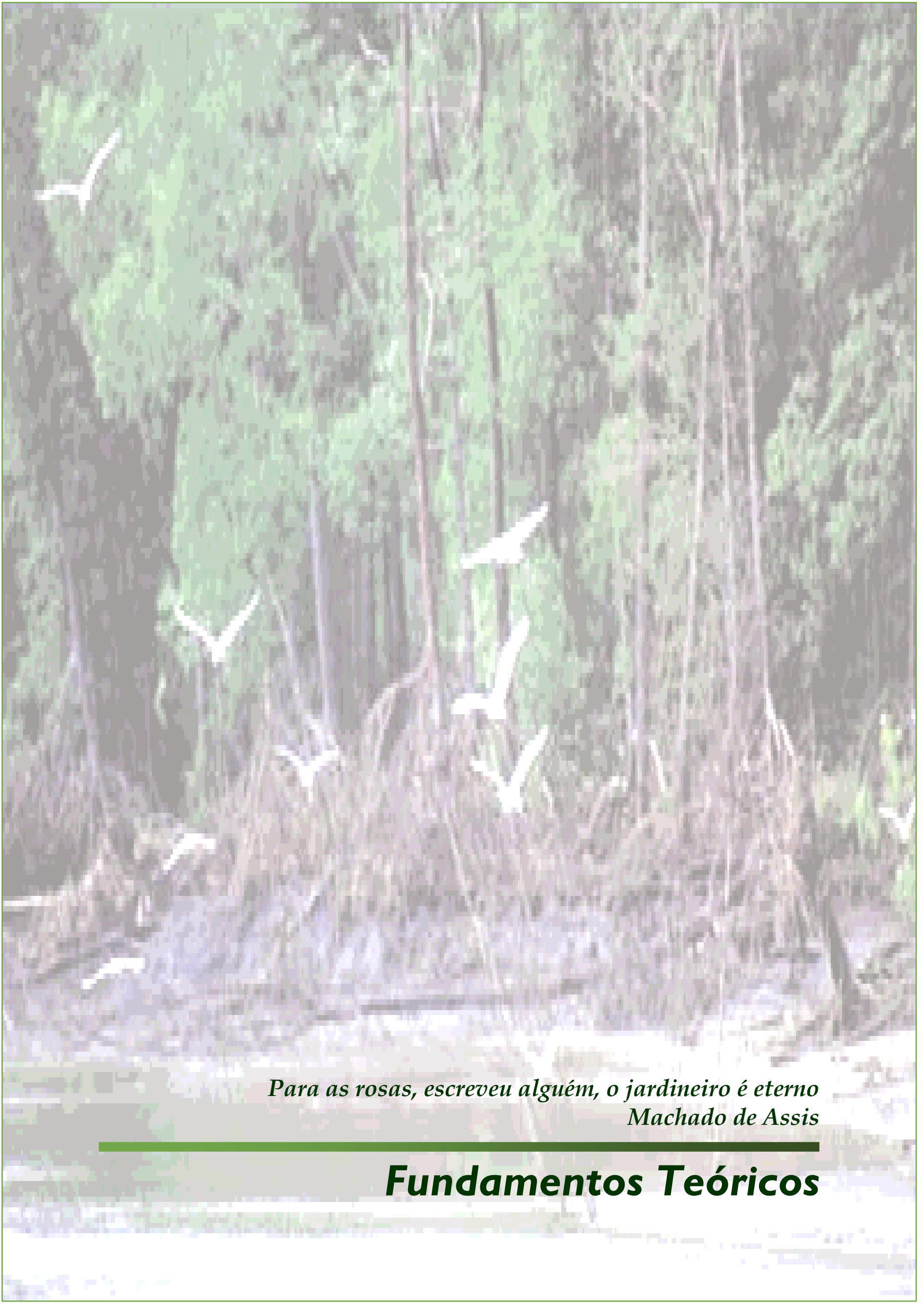




\section{FUNDAMENTOS TEÓRICOS}

\subsection{Substâncias Húmicas}

A decomposição química e biológica de plantas e animais e da atividade de microrganismos resulta em uma mistura de produtos em vários estágios de decomposição que constitui a matéria orgânica presente nas águas, nos solos, turfas e sedimentos. Essa matéria orgânica é usualmente classificada como húmus (SCHNITZER, 1988; STEVENSON, 1994).

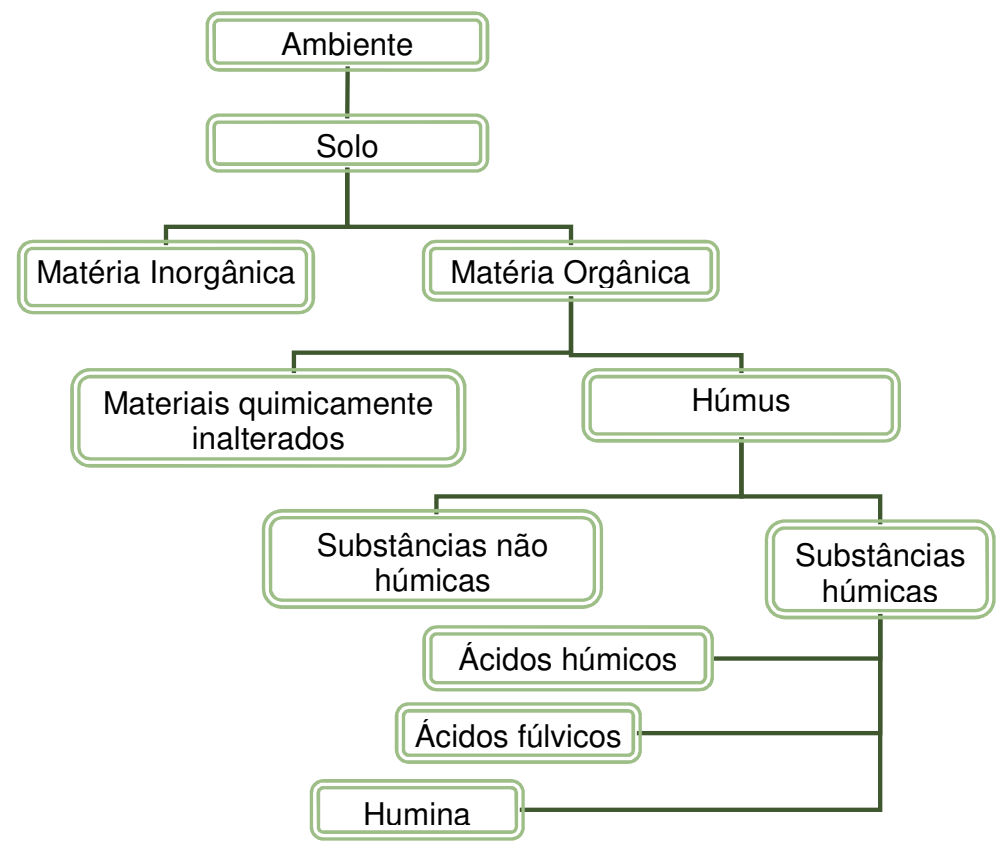

Figura 6: Distribuição da matéria orgânica no ambiente (extraído de LANDGRAF; MESSIAS; REZENDE, 2005).

O termo húmus, proveniente do latim, descreve o material de coloração escura do solo, que é rico em carbono, mas contém pouco hidrogênio e oxigênio. O húmus cumpre um papel importante na formação de agregados do solo, no controle da acidez, no ciclo dos elementos nutrientes, bem como na descontaminação de compostos indesejáveis (REZENDE, 1999). 
O húmus é constituído pelas substâncias húmicas e pelas substâncias não húmicas. As substâncias não húmicas são de natureza química bem definida, dentre elas aminoácidos, proteínas, carboidratos, gorduras e ácidos orgânicos; enquanto as substâncias húmicas não apresentam estrutura química conhecida, apenas modelos.

As substâncias húmicas (HS) são substâncias poliméricas, amorfas e de coloração escura, as quais constituem uma mistura heterogênea de compostos classificados de acordo com suas características de solubilidade em ácidos húmicos, humina e ácidos fúlvicos, onde cada fração húmica contém uma série de moléculas de tamanhos diferentes. Os ácidos húmicos (HA) constituem a fração húmica que é solúvel em meio alcalino, mas que se torna insolúvel se o meio é acidificado, enquanto que os ácidos fúlvicos (FA) permanecem em solução quando o meio é acido e as huminas se apresentam insolúveis tanto em meio ácido quanto em meio álcali diluídos (SCHNITZER; KODAMA; RIPMEESTER, 1991; MACCARTHY et al., 1990; REZENDE, 1999).

$\mathrm{Na}$ literatura existem várias estruturas propostas para as HS, entretanto não há consenso para afirmar um só modelo estrutural que determine a composição química, a forma e o tamanho. A variedade de materiais de origem e o grande número de caminhos reacionais possíveis para a formação do húmus constituem a razão para as dificuldades na sugestão de uma estrutura precisa para os HA e FA (LANDGRAF; MESSIAS; REZENDE, 2005).

No decorrer do século $X X$, diversos modelos de estruturas caracterizados por grupos funcionais similares, como alifáticos e aromáticos, foram propostos para as HS e os HA em particular. Schulten e Schnitzer (1993), a partir de técnicas analíticas como pirólise, espectroscopia, degradação oxidativa e microscopia eletrônica, propuseram a estrutura esquemática e macromolecular para os HA mostrada na figura 7. Neste modelo o oxigênio está presente como grupos carboxílicos, fenólicos, hidroxílicos, ésteres e éteres, enquanto o nitrogênio consta como estruturas heterocíclicas e nitrilas. Posteriormente, em 1997, Schulten e Schnitzer sugeriram o modelo conformacional apresentado na figura 8 , onde se destaca a existência de 
"vazios" hidrofóbicos dentro das moléculas capazes de interagir com outras substâncias.

A composição das HS depende da natureza química dos resíduos, dos microrganismos envolvidos e das condições em que se realiza o processo de decomposição. Embora sejam de natureza essencialmente orgânica, as HS contêm vários elementos inorgânicos que fazem parte integrante do sistema, tais como P, S, Ca, Mg, K e Al (REZENDE, 1999).

Devido às características estruturais, as HS interagem com metais e compostos orgânicos presentes no ambiente, tanto nutrientes quanto tóxicos. Deste modo, as HS podem não somente interferir no comportamento e destino destes compostos, como também controlar a disponibilidade dos mesmos para as plantas. Em solos tropicais, tais como os manguezais, a atividade microbiana é mais intensa devido à umidade e ao calor destes ecossistemas, e essa atividade, aliada a valores baixos de $\mathrm{pH}$, conferem às HS uma maior capacidade de interação com íons metálicos e pesticidas diversos.

Os íons metálicos e compostos orgânicos interagem com as HS devido à grande variedade dos grupos funcionais dos HA. O material húmico geralmente encontra-se mais concentrado nas camadas superficiais dos sedimentos. Consequentemente, os metais potencialmente tóxicos e os pesticidas organoclorados que estiverem presentes podem acumular-se nessas camadas, ficando assim mais acessíveis para as raízes das plantas, uma vez que o contato físico destes compostos com a raiz favorece a absorção dos mesmos pelo vegetal. 


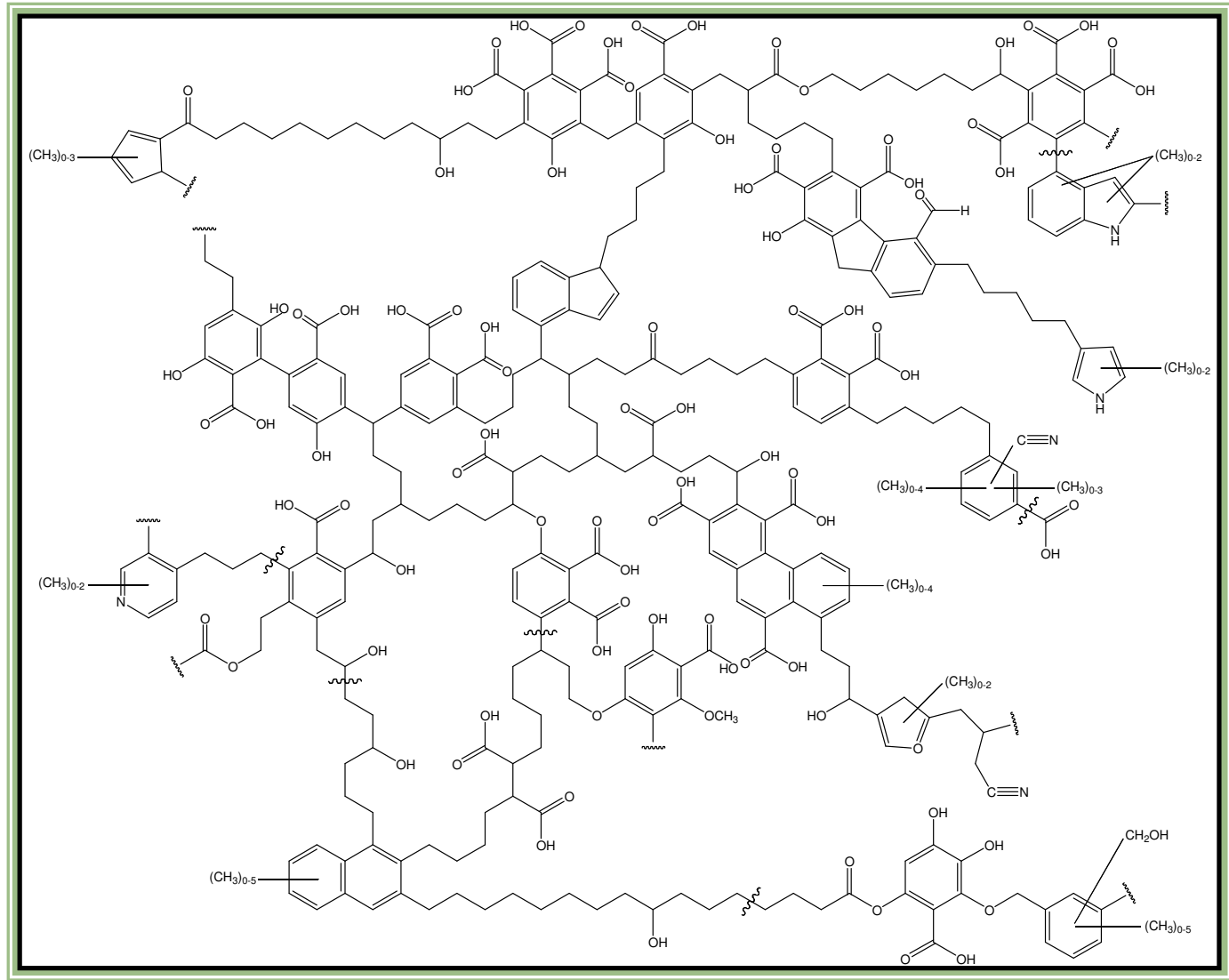

Figura 7: Modelo de estrutura de ácidos húmicos proposto por Schulten e Schnitzer (1993).

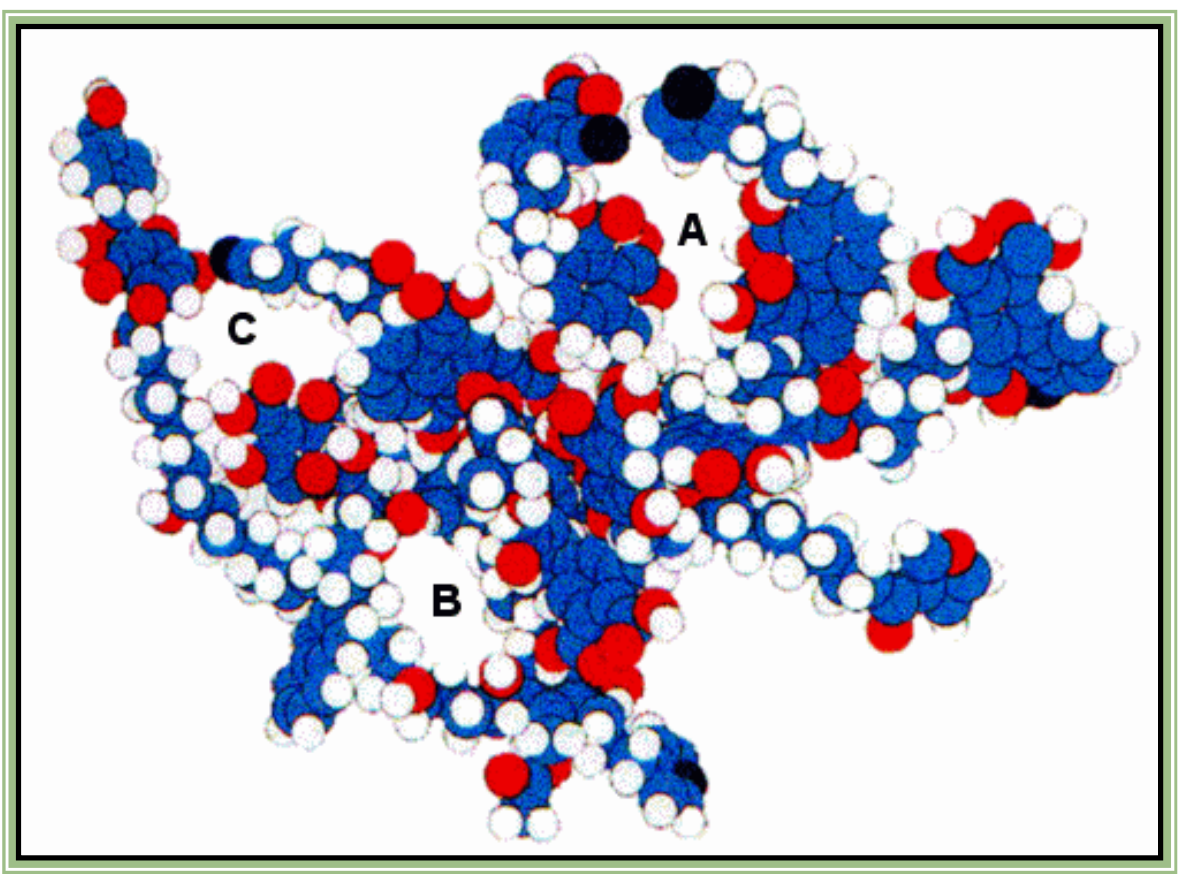

Figura 8: Modelo de estrutura de ácidos húmicos em 3D proposto por Schulten e Schnitzer (1997). Átomos de carbono são representados em azul, hidrogênio em branco, oxigênio em vermelho e nitrogênio em preto. As letras $A, B$ e $C$ indicam os espaços "vazios" presentes na estrutura, capazes de interagir com outros compostos. 


\subsection{Metais: Essencialidade e Toxicidade}

Nas últimas décadas, a urbanização e industrialização têm tornado cada vez mais crítica a questão da contaminação do meio ambiente. Em meio a tantas preocupações, os metais têm contribuído de forma significativa para a poluição de ambientes aquáticos, terrestres e atmosfera, transformando-se em uma nova e perigosa classe de contaminantes, uma vez que a intervenção humana na sua geração e utilização tem causado problemas em escala local e global, levando a um estresse da natureza e produzindo efeitos crônicos à saúde humana (BRAYNER, 1998; LEITE, 2002).

Os metais que chegam aos corpos d'água se complexam com as partículas que compõem o sedimento acumulando-se neste, o qual funciona como reservatório de contaminantes de baixa solubilidade e desempenha importante papel nos processos de assimilação, transporte e deposição para essas espécies químicas. Sendo assim, o sedimento é uma fonte potencial de contaminação primária para os organismos bentônicos e secundária para a coluna d’água (ADAMS, 1995; ZAMBETTA, 2006).

Alguns elementos como magnésio, ferro, zinco, manganês, cobre e cobalto são essenciais para o desenvolvimento das plantas e animais, pois atuam em diversos processos fisiológicos. Entretanto, se apresentarem concentrações elevadas, estes elementos podem se tornar prejudiciais. Por outro lado, outros metais como mercúrio, chumbo, cádmio, cromo e níquel, não têm função biológica conhecida e comumente apresentam toxicidade aos organismos vivos.

O potencial de toxicidade dos metais nos sedimentos e ambientes aquáticos depende de uma variedade de fatores que influenciam a disponibilidade destes para os organismos, incluindo a forma e concentração em que eles se encontram. Por sua vez, a forma em que os metais se encontram varia de acordo com as alterações ambientais, tais como mudanças de $\mathrm{pH}$, teor e composição de matéria orgânica, teor de oxigênio, salinidade entre outros. 
Tabela 3: Concentrações limite de metais totais em solos e sedimentos. Valores em ppm (mgkg ${ }^{-1}$ ) estabelecidos por diferentes fontes ${ }^{1}$.

\begin{tabular}{|c|c|c|c|c|c|c|c|c|c|c|c|c|}
\hline \multirow[t]{2}{*}{ Padrões } & \multicolumn{2}{|c|}{$\begin{array}{c}\text { CETESB } \\
\text { (CETESB, 2005) }\end{array}$} & \multicolumn{3}{|c|}{$\begin{array}{l}\text { Lista Holandesa }{ }^{2}-6530 \\
\text { (CETESB, 1999) }\end{array}$} & \multicolumn{3}{|c|}{$\begin{array}{l}\text { Lista Holandesa }{ }^{3}-6530 \\
\text { (CETESB, 1999) }\end{array}$} & \multicolumn{2}{|c|}{$\begin{array}{l}\text { Canadian Sediment } \\
\text { Quality - SQG } \\
\text { (CCME, 2002) }\end{array}$} & \multirow[t]{2}{*}{$\begin{array}{c}\text { Förstner; } \\
\text { Wittmann, } \\
1981\end{array}$} & \multirow[t]{2}{*}{$\begin{array}{c}\text { Thomas, } \\
1987\end{array}$} \\
\hline & VRQ & VP & VR (S) & VA (T) & VI (I) & VR (S) & VA (T) & VI (I) & ISQG & PEL & & \\
\hline Al & - & - & - & - & - & - & - & - & - & - & - & - \\
\hline Cd & 0,5 & 1,3 & 0,4 & 3,3 & 6,1 & 0,8 & 6,4 & 12 & 0,7 & 4,2 & 0,2 & 6 \\
\hline $\mathbf{P b}$ & 17 & 72 & 50 & 181 & 312 & 85 & 308 & 530 & 30,2 & 112 & 53,8 & 90 \\
\hline Co & 13 & 25 & 4 & 29 & 53 & 20 & 130 & 240 & - & - & - & - \\
\hline $\mathrm{Cu}$ & 35 & 60 & 15 & 47 & 79 & 36 & 113 & 190 & 18,7 & 108 & - & 25 \\
\hline $\mathrm{Cr}$ & 40 & 75 & 50 & 120 & 190 & 100 & 240 & 380 & 52,3 & 160 & 0,3 & 25 \\
\hline $\mathrm{Fe}$ & - & - & - & - & - & - & - & - & - & - & - & 17000 \\
\hline Mn & - & - & - & - & - & - & - & - & - & - & - & 300 \\
\hline $\mathrm{Ni}$ & 13 & 30 & 10 & 35 & 60 & 35 & 123 & 210 & - & - & 5 & 20 \\
\hline $\mathrm{Zn}$ & 60 & 300 & 50 & 154 & 257 & 140 & 430 & 720 & 124 & 271 & 50 & 90 \\
\hline
\end{tabular}

${ }^{1}$ As abreviaturas constam no início deste trabalho, na lista de abreviaturas;

${ }^{2}$ Lista Holandesa - valores de referência para solo com $0 \%$ de matéria orgânica;

${ }^{3}$ Lista Holandesa - valores de referência para solo com $10 \%$ de matéria orgânica. 
A composição do sedimento varia com as condições naturais do local, o que resulta em uma difícil tarefa quando se deseja estabelecer limites para as concentrações de metais totais ao designar se o sedimento está poluído ou não. Alguns valores podem ser demonstrados na tabela 3, de acordo com seus autores.

A Resolução no 357 de 17/03/2005 do Conselho Nacional do Meio Ambiente (CONAMA) que dispõe sobre a classificação dos corpos d'água e diretrizes ambientais para o seu enquadramento, estabelece condições e padrões de lançamento de efluentes para águas salobras da classe 1, a qual engloba as águas do projeto em questão. Assim, são apresentados alguns limites de lançamentos na tabela 4.

Tabela 4: Concentrações limite para lançamento de metais em águas salobras da classe 1 (Resolução no 357 de 17/03/05 do CONAMA).

\begin{tabular}{|cc|}
\hline Padrões & $\begin{array}{c}\text { Águas Salobras }- \text { Classe 1 } \\
\text { Valor máximo }\left(\mathrm{mg} \mathrm{L}^{-1}\right)\end{array}$ \\
\hline Al dissolvido & 0,1 \\
\hline Cd total & 0,005 \\
\hline Pb total & 0,01 \\
\hline Cu dissolvido & 0,005 \\
\hline Cr total & 0,05 \\
\hline Fe dissolvido & 0,3 \\
\hline Mn total & 0,1 \\
\hline Ni total & 0,025 \\
\hline Zn total & 0,09 \\
\hline
\end{tabular}

\subsubsection{Alumínio (Al)}

Metal branco brilhante, leve, dúctil, maleável e resistente à corrosão, o alumínio é o terceiro elemento mais abundante, em peso, na crosta terrestre e encontra-se amplamente disperso na forma de silicatos. Este metal faz parte da composição de um grande número de rochas e pedras preciosas, dentre elas as micas, os feldspatos, a bauxita, as safiras e os rubis. O alumínio é o principal constituinte de um grande número de componentes atmosféricos, 
particularmente de poeira derivada de solos e partículas originadas da combustão de carvão (O’NEILL, 1993; LEE, 1996; CETESB, 2004b).

Em contato com o ar ou em presença de água, o alumínio forma uma fina camada de óxido que o protege de ataques do meio ambiente. No entanto, em contato com outros elementos presentes no ar e na terra, e na presença de oxigênio, pode sofrer reação de combustão e liberar grande quantidade de calor e, ao combinar-se com halogênios ou enxofre, produz haletos e sulfetos de alumínio, respectivamente (O’NEILL, 1993; LEE, 1996).

Em ambientes aquáticos, o alumínio ocorre naturalmente em íons hidratados e complexado como silicatos na forma coloidal, em pequenas e grandes concentrações, respectivamente. O comportamento do alumínio é influenciado pelo $\mathrm{pH}$, pela temperatura e presença de fluoretos, sulfatos, matéria orgânica e outros ligantes. A solubilidade deste elemento é baixa em valores de $\mathrm{pH}$ entre 5,5 e 6, porém em ambientes mais ácidos, como em ambientes profundos e anaeróbios, o alumínio pode ser mais solúvel como os íons $\mathrm{Al}_{2} \mathrm{O}_{3} \mathrm{H}^{2+}$ e $\mathrm{AlOH}^{2+}$, enquanto em ambientes alcalinos forma íons como $\mathrm{HAl}_{2} \mathrm{O}_{4}$. Outro fator que influencia na concentração do alumínio são as chuvas; em estações chuvosas com alta turbidez, há um aumento na concentração deste metal, sendo encontrado em menores quantidades em épocas secas (O'NEILL, 1993; CETESB, 2004b; ANJOS, 2003).

A toxicidade do alumínio é considerada baixa, porém a exposição a altas concentrações pode ser prejudicial à saúde, principalmente quando este está na forma de íons solúveis em água. A intoxicação por este metal tem sido associada à constipação intestinal, cólicas abdominais, anorexia, náuseas, fadiga, alterações do metabolismo do cálcio (raquitismo), alterações neurológicas com graves danos ao tecido cerebral e, em crianças, pode causar hiperatividade e distúrbios do aprendizado. Estudos revelam que o alumínio pode cumprir um importante papel no agravamento do mal de Alzheimer (demência precoce). Não há indicação de carcinogenicidade para o alumínio (CETESB, 2004b). 


\subsubsection{Cádmio (Cd)}

Metal branco azulado, dúctil e maleável, o cádmio é um elemento escasso na crosta terrestre. Suas reservas são raras e geralmente este metal é encontrado na natureza associado ao oxigênio, cloro e principalmente enxofre na forma de sulfeto em minerais de zinco e cádmio, como a esfalerita e a greenockita, respectivamente. A obtenção de cádmio ocorre na maioria das vezes, como subproduto na mineração de zinco e em menor quantidade nas de chumbo e cobre. Quando encontrado em águas naturais, o cádmio pode ser proveniente de descargas de efluentes industriais, principalmente a galvanoplastia, produção de pigmentos, soldas, equipamentos eletrônicos, lubrificantes e acessórios fotográficos. A queima de combustíveis fósseis também consiste em uma fonte de cádmio para o ambiente (O’NEILL, 1993; LEE, 1996; CETESB, 2004b).

De acordo com Smith et al. (1995), a depender dos valores de $\mathrm{pH}$ e o potencial redox (Eh), o cádmio pode apresentar as seguintes formas de estabilidade: 0 cátion $\mathrm{Cd}^{2+}$ e $\mathrm{CdSO}_{4}$ para valores de $\mathrm{pH}$ aproximadamente entre 0 e 2 e ambiente oxidante; CdS e Cd para qualquer valor de $\mathrm{pH}$ e Eh baixo e altamente redutor, respectivamente; $\mathrm{CdCO}_{3}, \mathrm{Cd}(\mathrm{OH})_{2}$ para $\mathrm{pH}$ em uma faixa de aproximadamente 4 a 14 com Eh oxidante (figura 9). A remoção do cádmio em água aumenta com os valores de $\mathrm{pH}$ variando de 6 a 9, mas em $\mathrm{pH}$ abaixo de 6 pouco ou nenhum cádmio é removido. A sorção do cádmio está muitas vezes correlacionada com a capacidade de troca catiônica de minerais argilosos, carbonatados, óxidos e matéria orgânica de solos e sedimentos (ANJOS, 2003; SMITH et al., 1995).

Em ambientes aquáticos, o cádmio está presente em concentrações traço, geralmente inferiores a $1 \mu^{-1}$. No entanto, por ser quimicamente similar ao zinco, o cádmio é absorvido facilmente pelas plantas, o que possibilita sua entrada na cadeia alimentar. Organismos como crustáceos e mariscos são acumuladores naturais de cádmio. Além de alimentos aquáticos contaminados, outras fontes de intoxicação por cádmio podem ser fígados e rins de animais terrestres, farinhas e açúcares refinados, além da fumaça de cigarros que contém elevados teores deste elemento (O’NEILL, 1993). 


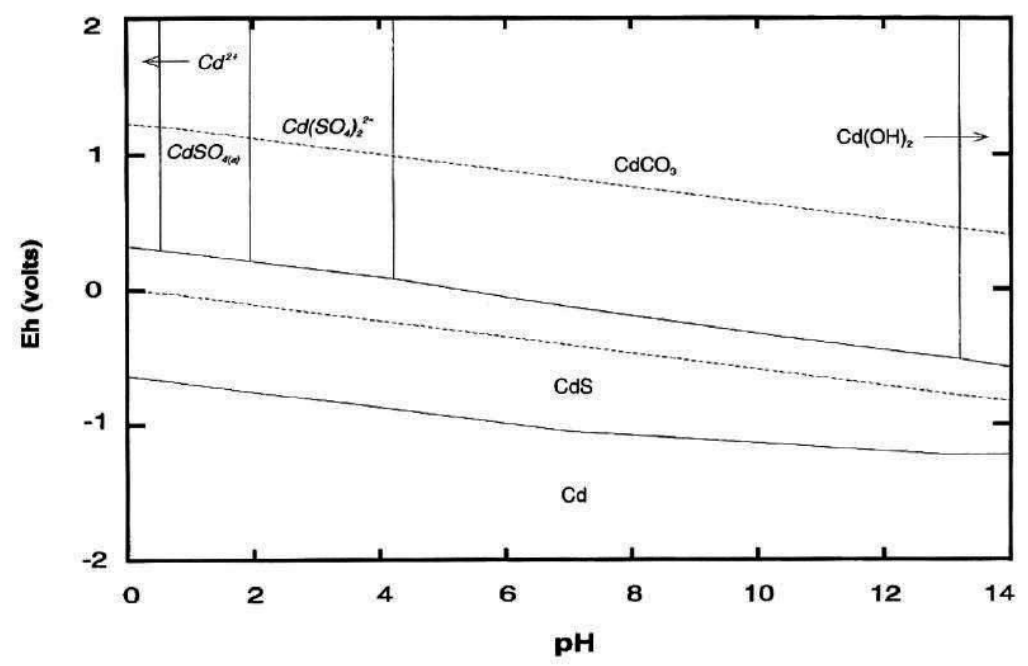

Figura 9: Estabilidade de espécies de cádmio em variações de $\mathrm{pH}$ e potencial redox (extraído de USEPA, 1984 apud SMITH et al., 1995).

O cádmio não apresenta nenhuma qualidade, pelo menos conhecida até o presente, que o torne benéfico ou essencial para os seres vivos. É considerado um metal altamente tóxico que produz efeito crônico, pois se concentra nos rins, no fígado, no pâncreas e na tireóide; e efeito agudo, sendo que uma única dose de $9 \mathrm{~g}$ pode levar à morte. Intoxicações leves podem causar: salivação, fadiga, perda de peso, fraqueza muscular e disfunção sexual. Concentrações elevadas e exposições prolongadas a este metal podem afetar os rins, pulmões, testículos, paredes arteriais, ossos, interferir com muitos sistemas enzimáticos e causar doenças crônicas em idosos, além de causar câncer (CETESB, 2004b).

\subsubsection{Chumbo $(\mathrm{Pb})$}

O chumbo é um metal macio, maleável e pobre condutor de eletricidade, que apresenta coloração branco-azulada, mas se torna acinzentada quando exposto ao ar. Os principais minérios de chumbo são a galena ( $\mathrm{PbS})$, a cerrusita $\left(\mathrm{PbCO}_{3}\right)$ e a anglesita $\left(\mathrm{PbSO}_{4}\right)$. Este elemento foi muito usado no passado para armazenar água e alimentos, como pigmento em tintas e como 
aditivo na gasolina, sendo responsável por inúmeros casos de intoxicação (LEE, 1996; PURVES, 1985; TOMAZELLI, 2003).

Em muitos países o chumbo foi banido de muitas atividades, no entanto ainda pode ser encontrado no tabaco; nas bebidas e alimentos por contaminação da embalagem; na água devido às descargas de efluentes industriais proveniente de indústrias de acumuladores (baterias) ou do uso indevido de tintas, tubulações e acessórios para materiais de construções; além da utilização em eletrodeposição e metalurgia (CETESB, 2004b).

As diversas formas em que se encontra o chumbo em relação às variações de $\mathrm{pH}$ e o potencial redox (Eh) do meio são apresentadas na figura 10. Em condições oxidantes e qualquer faixa de $\mathrm{pH}$, forma-se $\mathrm{O} \mathrm{PbO}_{2}$; em condições oxidantes e $\mathrm{pH}$ entre 0 e 6, forma-se $0 \mathrm{PbSO}_{4}$ e o cátion $\mathrm{Pb}^{2+}$; na interface entre os ambientes oxidante e redutor encontram-se as formas $\mathrm{PbCO}_{3}$ e $\mathrm{Pb}(\mathrm{OH})_{2}$ com valores de $\mathrm{pH}$ de 6 a 10 e de 10 a 14, respectivamente; enquanto que as espécies $\mathrm{PbS}$ e $\mathrm{Pb}$ podem ser estáveis em ambiente redutor e pH variável (ANJOS, 2003; SMITH et al., 1995).

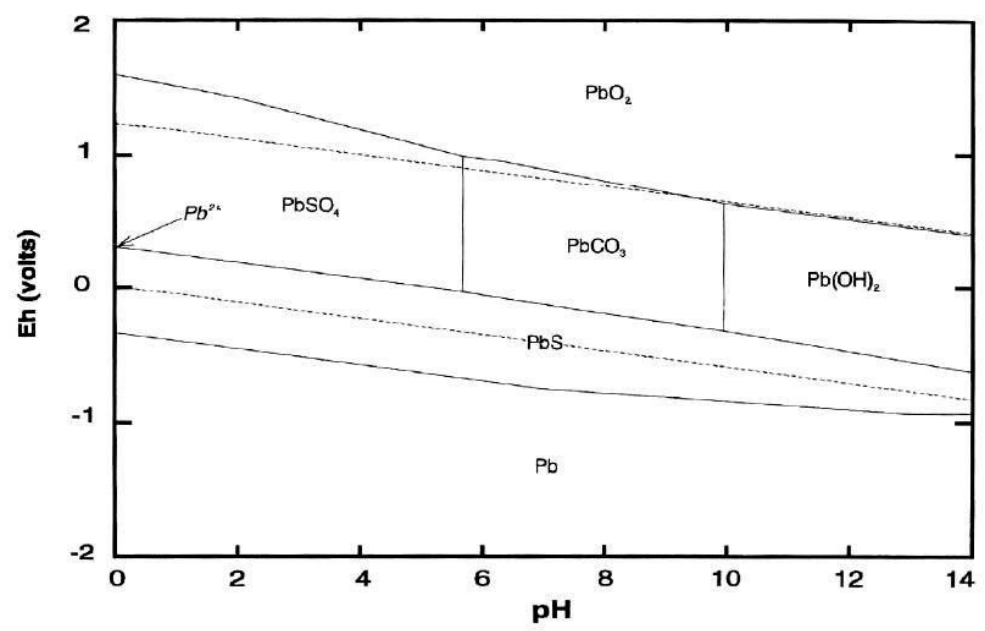

Figura 10: Estabilidade de espécies de chumbo em variações de $\mathrm{pH}$ e potencial redox (extraído de USEPA, 1984 apud SMITH et al., 1995).

Nas águas superficiais, o transporte do chumbo é baixo e sua concentração depende dos valores de $\mathrm{pH}$ e a quantidade de sais dissolvidos. Em valores de $\mathrm{pH}$ acima de 5,4 sua solubilidade pode chegar a $500 \mathrm{\mu gL}^{-1}$ para águas pobres em cálcio e magnésio e a $30 \mathrm{\mu L}^{-1}$ para águas ricas em cálcio e 
magnésio. Nos sedimentos, o destino do chumbo é afetado por processos de adsorção, troca de íons, precipitação, e complexação com a matéria orgânica, a qual é eficaz na fixação deste metal. $O$ chumbo tem afinidade por ligantes orgânicos e forma complexos que aumenta sua mobilidade nos solos e sedimentos de maneira similar ao cádmio. De maneira geral, o chumbo é tem baixa solubilidade e é persistente no meio ambiente (ANJOS, 2003; SMITH et al., 1995).

Muitos efeitos adversos à saúde são atribuídos às altas concentrações de chumbo no corpo, incluindo toxicidade nervosa, renal, endócrina, ossos entre outros. Alguns sintomas da exposição crônica ao chumbo, quando o efeito ocorre no sistema nervoso central, são: tontura, irritabilidade, dor de cabeça, perda de memória, entre outros; e quando o efeito ocorre no sistema periférico o sintoma é a deficiência dos músculos extensores. A intoxicação aguda é caracterizada pela sede intensa, sabor metálico, inflamação gastrintestinal, vômitos e diarréias (CETESB, 2004b).

A toxicidade do chumbo depende da idade e da dose de exposição, a absorção deste metal pelo corpo é muito maior em crianças do que em adultos. $\mathrm{O}$ adulto em geral absorve $10 \%$ do chumbo que passa pelo trato digestivo, enquanto crianças absorvem $50 \%$, sendo a maior parte retida e acumulada no esqueleto, apresentando meia vida de 20 anos. Inicialmente, o chumbo ingerido vai para o sangue, mas em excesso, entra para os tecidos, incluindo os órgãos, particularmente o cérebro e, eventualmente, o chumbo deposita-se nos ossos tomando o lugar do cálcio, devido a similaridade no tamanho de seus íons bivalentes (TOMAZELLI, 2003; ANJOS, 2003).

O chumbo é considerado padrão de potabilidade, de emissão de esgotos e de classificação das águas naturais. Para a potabilidade, o valor máximo permissível é de $0,03 \mathrm{mgL}^{-1}$ pela Portaria 1469 do Ministério da Saúde, o mesmo valor adotado nos Estados Unidos. Em peixes, as doses fatais, no geral, variam de 0,1 a 0,4 $\mathrm{mgL}^{-1}$, embora, em condições experimentais, alguns resistam até $10 \mathrm{mgL}^{-1}$. Outros organismos como moluscos, crustáceos, vermes e sanguessugas, morrem em concentrações superiores a $0,3 \mathrm{mgL}^{-1}$ (CETESB, 2004b). 


\subsubsection{Cobalto (Co)}

O cobalto é um metal branco azulado e lustroso, duro, ferromagnético e pouco abundante na crosta terrestre. Existem muitos minérios contendo cobalto, dentre os principais a cobaltita (CoAsS), a esmaltita ( $\mathrm{CoAs}_{2}$ ) e a linneita $\left(\mathrm{CO}_{3} \mathrm{~S}_{4}\right)$. No entanto, estes minerais são encontrados junto aos minérios de níquel, cobre e poucas vezes de chumbo; razão pela qual o cobalto é obtido como subproduto da extração destes outros metais (LEE, 1996).

Cerca de um terço da produção de cobalto é utilizada na indústria do aço, formando ligas metálicas que encontram empregos importantes em turbinas a jato e em aços rápidos usados na fabricação de ferramentas de corte, devido à dureza deste metal. Outro terço da produção de cobalto é empregado na fabricação de pigmento azul para as indústrias de cerâmica, vidro e tintas. Devido à propriedade ferromagnética, o cobalto é usado em ligas de imãs permanentes, 20 a 30 vezes mais fortes que os imãs de ferro. Além destes, o cobalto também é aplicado em secantes para pinturas, em eletrodos de baterias elétricas, na catálise do petróleo e na medicina, através da produção de pinos e placas para o corpo humano em caso de fraturas e como fonte de radiação gama $\left({ }^{60} \mathrm{Co}\right)$ tratamento de câncer (LEE, 1996).

O cobalto está presente em algumas enzimas e é um elemento essencial, quando em pequenas quantidades, para numerosas formas de vida, incluindo o ser humano. É um importante constituinte do solo fértil e o componente central da vitamina $B_{12}$. Entretanto, assim como em outros metais que são essenciais aos organismos vivos, concentrações altas de cobalto se tornam prejudiciais. $\mathrm{O}$ isótopo ${ }^{60} \mathrm{Co}$ é utilizado na radioterapia no tratamento de câncer e, uma eventual inadequada manipulação ou manutenção das unidades de radioterapia, podem ocasionar uma exposição a esta espécie, que se acumula nos tecidos e provoca o câncer (LEE, 1996). 


\subsubsection{Cobre $(\mathrm{Cu})$}

Metal dúctil, maleável, e excelente condutor térmico e elétrico, o cobre apresenta uma coloração avermelhada. É moderadamente abundante e pode ser encontrado em várias formas minerais como a calcocita $\left(\mathrm{Cu}_{2} \mathrm{~S}\right)$, a malaquita $\left(\mathrm{CuCO}_{3} \cdot \mathrm{Cu}(\mathrm{OH})_{2}\right)$, a cuprita $\left(\mathrm{CuO}_{2}\right)$, a bornita $\left(\mathrm{Cu}_{5} \mathrm{FeSO}_{4}\right)$, a turquesa $\left(\mathrm{CuAl}_{6}\left(\mathrm{PO}_{4}\right)_{4}(\mathrm{OH})_{8} .4 \mathrm{H}_{2} \mathrm{O}\right)$ e a calcopirita $\left(\mathrm{CuFeS}_{2}\right)$, sendo mais comum nesta última. Este metal é muito utilizado na indústria elétrica devido sua elevada condutividade; em tubulações de água por sua inércia química; em diversas ligas metálicas como produção do bronze e moedas; além de ter larga aplicação na agricultura (LEE, 1996).

Em pequenas quantidades, o cobre é um elemento essencial para algumas formas de vida, pois participa de alguns processos enzimáticos em funções vitais; exerce importante papel na síntese da clorofila; além de atuar no organismo humano como catalisador na assimilação do ferro e seu aproveitamento na síntese da hemoglobina, facilitando a cura de anemias. Existem poucos casos que relatam efeitos agudos do cobre, dentre eles: queimação gástrica, náuseas, vômitos, diarréias, lesões no trato gastrintestinal e anemia hemolítica; enquanto o efeito crônico é raramente reportado, com exceção do Mal de Wilson, responsável pelo acúmulo de cobre no fígado, cérebro e rim (QUINAGLIA, 2001; ANJOS, 2003; CETESB, 2004b).

Em ambientes aquáticos, o cobre ocorre naturalmente em concentrações inferiores a $20 \mathrm{\mu gL}^{-1}$, porém, em concentrações elevadas, é prejudicial à saúde e confere sabor às águas, além de ser extremamente nocivo aos peixes. Assim, trutas, carpas, bagres e outras espécies morrem em dosagens de $0,5 \mathrm{mgL}^{-1}$ pela coagulação do muco das brânquias e conseqüente asfixia. As fontes de cobre para o meio ambiente incluem corrosão de tubulações por águas ácidas; efluentes de estações de tratamento de esgotos; uso de compostos de cobre como algicidas aquáticos; escoamento superficial e contaminação da água subterrânea a partir de usos agrícolas do cobre como fungicida e pesticida no tratamento de solos e efluentes; além da precipitação atmosférica de fontes industriais como indústrias de mineração, fundição e refinação (CETESB, 2004b). 
O cobre, juntamente com o chumbo, é considerado um metal de baixa mobilidade e é facilmente retido nos solos e sedimentos por meio de mecanismos de adsorção e troca catiônica. Em ambientes aeróbios e suficientemente alcalinos, $\mathrm{CuCO}_{3}$ é a forma solúvel do cobre que predomina, mas o íon $\mathrm{Cu}^{2+}$ e seus respectivos hidróxidos $\mathrm{CuOH}^{+}$e $\mathrm{Cu}(\mathrm{OH})_{2}$ também são comuns. O cobre forma complexos fortes com os ácidos húmicos, a afinidade deste elemento pelo húmus aumenta à medida que $\mathrm{o} \mathrm{pH}$ aumenta e a força iônica diminui. Já em ambientes anaeróbios e ácidos, o cobre encontra-se mobilizado na forma de sulfetos, CuS (EVANKO; DZOMBAK, 1997).

\subsubsection{Cromo (Cr)}

Metal duro, frágil, resistente à corrosão e de coloração cinza, o cromo é relativamente abundante na crosta terrestre e a cromita $\left(\mathrm{FeCr}_{2} \mathrm{O}_{4}\right)$ é o seu principal minério. Este metal é muito usado em ligas metálicas e na eletrodeposição nas indústrias metalúrgicas, mas também é aplicado em nas indústrias químicas, na produção de tintas e corantes, no curtimento de couro, na produção de fotografias, papel, explosivos dentre outros (LEE, 1996; CETESB, 2004b).

O cromo na forma trivalente juntamente a insulina está envolvido na manutenção do nível correto de glicose no sangue e a ausência deste pode ocasionar em diabetes, portanto, esta forma do metal é essencial ao metabolismo humano e, sua carência, causa doenças. No entanto, quando na forma hexavalente, é tóxico e cancerígeno, podendo causar perfurações no trato respiratório, irritações no trato gastrintestinal, e até ser letal em doses mínimas. Os limites máximos permissíveis no ambiente são estabelecidos basicamente em função do cromo hexavalente (CETESB, 2004b).

Assim como os outros metais, o comportamento do cromo depende das variações do $\mathrm{pH}$ e do potencial redox. Em ambientes aquáticos e condições aeróbias, bem como na presença de óxidos de ferro e manganês, a forma predominante é o cromo(VI). Entretanto, em condições anaeróbias, o cromo(VI) 
pode ser reduzido a cromo(III) pela matéria orgânica do solo, bem como pelos íons $\mathrm{S}^{2-}$ e $\mathrm{Fe}^{2+}$, o que geralmente ocorre em maiores profundidades. As principais espécies do cromo(VI) incluem o cromato $\left(\mathrm{CrO}_{4}{ }^{2-}\right)$ e o dicromato $\left(\mathrm{Cr}_{2} \mathrm{O}_{7}{ }^{2-}\right)$, os quais precipitam na presença de cátions metálicos como $\mathrm{Ba}^{2+}$, $\mathrm{Pb}^{2+}$, e $\mathrm{Ag}^{+}$. Em ambientes com baixos valores de $\mathrm{pH}(<4)$, a forma predominante do cromo é o cromo(III). O cátion $\mathrm{Cr}^{3+}$ forma complexos em solução com as espécies $\mathrm{NH}_{3}, \mathrm{OH}^{-}, \mathrm{Cl}^{-}, \mathrm{F}^{-}, \mathrm{CN}^{-}, \mathrm{SO}_{4}{ }^{2-}$ e ligantes orgânicos solúveis (EVANKO; DZOMBAK, 1997).

O cromo(VI) é a forma mais tóxica do cromo e também a de maior mobilidade, enquanto que a mobilidade do cromo(III) é pequena devido a adsorção em argilas e óxidos de minerais em valores de $\mathrm{pH}$ abaixo de 5 e devido a baixa solubilidade em $\mathrm{pH}$ acima de 5 , onde ocorre a formação do $\mathrm{Cr}(\mathrm{OH})_{3(\mathrm{~s})}$ (CHROTOWSKI et al., 1991). Em geral, a mobilidade do cromo depende das características de sorção do solo, incluindo a proporção de argila e óxido de ferro, bem como a quantidade de matéria orgânica (EVANKO; DZOMBAK, 1997; SMITH et al., 1995).

\subsubsection{Ferro (Fe)}

O ferro puro não é muito duro, é bastante reativo, tem propriedades magnéticas, apresenta coloração cinza prateada e é o quarto elemento mais abundante, em peso, na crosta terrestre. Este metal, dentre outros, é o mais utilizado para a produção do aço e diversas ligas metálicas que são empregados em fábricas de máquinas, ferramentas, veículos de transporte, na construção civil, e outra variedade de aplicações. Os principais minérios de ferro são a hematita $\left(\mathrm{Fe}_{2} \mathrm{O}_{3}\right)$, a magnetita $\left(\mathrm{Fe}_{3} \mathrm{O}_{4}\right)$, a limonita $(\mathrm{FeO}(\mathrm{OH}))$ e a siderita $\left(\mathrm{FeCO}_{3}\right)$, também são encontradas pequenas quantidades de pirita $\left(\mathrm{FeS}_{2}\right)(\mathrm{LEE}, 1996)$.

O ferro está presente no ambiente tanto por processos naturais como devido a fontes antropogênicas, como por exemplo, a contribuição de efluentes industriais, através de indústrias metalúrgicas que desenvolvem atividades de 
remoção da camada oxidada (ferrugem) das peças antes de seu uso, processo conhecido por decapagem, que normalmente é procedida através da passagem da peça em banho ácido.

As mudanças no estado da oxidação do ferro na crosta terrestre são de grande importância para compreender suas propriedades, incluindo a mobilidade. Muitos dos fatores que são importantes para o ferro são também importantes para outros elementos com estados de oxidação variáveis, o manganês por exemplo, é muito similar ao ferro. As estabilidades relativas do ferro (II) e do ferro (III) são tais que apenas pequenas alterações nas condições ambientais naturais podem fazer com que o ferro (II) seja oxidado a ferro (III) ou o ferro (III) seja reduzido a ferro (II), ocorrendo considerável mudança na solubilidade (O'NEILL, 1993).

O ferro é um micronutriente indispensável ao metabolismo dos seres vivos e as diversas formas em que se encontra nos ambientes aquáticos depende das variações nas condições redox, do $\mathrm{pH}$ e temperatura do meio. $\mathrm{Na}$ forma reduzida $\left(\mathrm{Fe}^{2+}\right)$, o ferro torna-se solúvel principalmente sob a forma iônica ou bicarbonato, bem como suspensa, adsorvida em partículas e complexada a substâncias orgânicas. $\mathrm{Na}$ forma oxidada $\left(\mathrm{Fe}^{3+}\right)$, a maior parte do ferro encontra-se precipitado ou complexado na forma de hidróxido de ferro hidratado. $O$ ferro exerce grande influência sobre a ciclagem do fósforo no sistema, principalmente devido à co-precipitação de espécies fosfatadas adsorvidas química ou fisicamente a superfície de partículas de hidróxido de ferro hidratado, que é formado sob condições aeróbias ou através da ação de bactérias ferruginosas (ESTEVES, 1998; OLIVEIRA, 2006).

Em ambientes aquáticos com condições aeróbias e em altos valores de $\mathrm{pH}$, ocorre precipitação de boa parte do ferro, o que diminui sua concentração na coluna d'água e, ao contrário, em condições redutoras e anaeróbias, o ferro encontra-se na sua forma reduzida solúvel, ferro(II), causando o aumento de sua concentração. No entanto, em ambientes ricos em substâncias húmicas, o processo realizado por bactérias que utilizam a matéria orgânica complexada ao ferro, ocasiona a liberação de ferro(II) que é rapidamente oxidado e produz 
hidróxido de ferro(III), que por sua vez, precipita e faz com que a concentração de ferro diminua (ESTEVES, 1998; OLIVEIRA, 2006).

Nas águas tratadas para abastecimento urbano, o emprego de coagulantes a base de ferro provoca elevação em seu teor. O ferro, apesar de não ter alta toxicidade, traz diversos problemas para o abastecimento público de água, pois confere cor e sabor à água, provocando manchas em roupas e utensílios sanitários. Além disso, ocasiona problemas depositando-se em canalizações e gerando ferro-bactérias, provocando a contaminação biológica da água na própria rede de distribuição. Por estes motivos, o ferro constitui-se em padrão de potabilidade, de emissão de esgotos e de classificação das águas naturais, estabelecendo-se a concentração limite de $0,3 \mathrm{mgL}^{-1}$ na Portaria 1469 do Ministério da Saúde. As águas que contêm ferro caracterizamse por apresentar cor elevada e turbidez baixa (CETESB, 2004b).

Pequenas quantidades de ferro são essenciais para a vida, tanto animal, como vegetal, contudo, assim como ocorre em alguns outros casos, é tóxico em quantidades elevadas. Do ponto de vista biológico, o ferro é o mais importante dentre os metais de transição, pois está envolvido em processos como o transporte do oxigênio no sangue (hemoglobina) nos animais; no armazenamento do oxigênio nos tecidos musculares (mioglobina); no transporte de elétrons em plantas, animais e bactérias; na nitrogenase e em diversas outras enzimas (LEE, 1996).

\subsubsection{Manganês (Mn)}

O manganês é um metal duro, mais reativo que seus vizinhos na tabela periódica, apresenta coloração branca acinzentada parecido com o ferro e é o décimo segundo elemento mais abundante, em peso, na crosta terrestre. 0 manganês é produzido em grandes quantidades e, assim como o ferro, também é empregado na indústria do aço e ligas metálicas, além de outras aplicações como em "pilhas secas", na indústria química em tintas e vernizes, 
em fogos de artifício, em fertilizantes e na indústria de cerâmica e vidro. Seu principal minério é a pirolusita $\left(\mathrm{MnO}_{2}\right)$ (LEE, 1996; CETESB, 2004b).

O comportamento do manganês em ambientes aquáticos é muito semelhante ao do ferro, porém sua ocorrência é mais rara. O manganês desenvolve coloração negra na água, predominando os estados de oxidação $\mathrm{Mn}^{2+}$ (forma mais solúvel) e $\mathrm{Mn}^{4+}$ (forma menos solúvel). A concentração de manganês menor que $0,05 \mathrm{mgL}^{-1}$ geralmente é aceitável em mananciais, devido ao fato de não ocorrerem, nesta faixa de concentração, manifestações de manchas negras ou depósitos de seus óxidos nos sistemas de abastecimento de água. Raramente atinge concentrações de $1,0 \mathrm{mgL}^{-1} \mathrm{em}$ águas superficiais naturais e, normalmente, está presente em quantidades de $0,2 \mathrm{mgL}^{-1}$ ou menos (CETESB, 2004b).

Os sulfetos do manganês são muito instáveis, e estes somente são formados quando o total de enxofre dissolvido excede o total de carbonatos por um fator de pelo menos 100. Conseqüentemente, o MnS quase nunca é detectado em ambientes redutores, como por exemplo os manguezais. Sob condições predominantemente anaeróbias, muitas bactérias que oxidam a matéria orgânica e reduzem o ferro(III), também reduzem o manganês(IV), utilizando este como receptor de elétrons. Esta redução ocorre facilmente através dos mecanismos não enzimáticos gerando manganês(II) que é mais solúvel e consequentemente, uma fração significativa deste elemento estaria disponível para as plantas, entretanto, este mecanismo também disponibiliza manganês para a água (LACERDA; RIBEIRO Jr.; GUEIROS, 1999).

O manganês tem importância biológica e é essencial, em quantidades muito pequenas, para o crescimento das plantas, por isso, onde há deficiência de manganês nos solos, ele é adicionado como fertilizantes. Este metal é importante para a fotossíntese e faz parte de um grupo de enzimas denominadas fosfotransferases. O manganês(II) é importante tanto em enzimas animais quanto em enzimas vegetais. Em mamíferos, a enzima arginase é produzida no fígado e converte os produtos nitrogenados do metabolismo em uréia, que por sua vez é levada pelo sangue aos rins, onde é excretada pela urina (LEE, 1996). 


\subsubsection{Níquel ( $\mathrm{Ni})$}

Metal dúctil, maleável, bom condutor térmico e elétrico, o níquel possui coloração branca prateada e é moderadamente abundante na crosta terrestre. Este metal é utilizado em grandes quantidades em uma ampla variedade de ligas, como por exemplo, na fabricação de moedas, imãs, motores, baterias, além do uso em indústrias químicas. Minérios de níquel de importância econômica incluem os sulfetos, geralmente misturados aos sulfetos de ferro e cobre e depósitos aluviais de silicatos e óxidos/hidróxidos. O mineral que se destaca é a pentlandita $\left((\mathrm{Fe}, \mathrm{Ni})_{9} \mathrm{~S}_{8}\right)$, mas o níquel pode ser encontrado em outros minérios como a millerita (NiS), nicolita (NiAs), a pirita arsenical de níquel (NiAsS), entre outros (LEE, 1996).

Estudos recentes demonstram que o níquel é carcinogênico. Não existem muitas referências bibliográficas quanto à toxicidade do níquel, todavia, assim como para outros íons metálicos, é possível mencionar que, em soluções diluídas, estes elementos podem precipitar a secreção da mucosa produzida pelas brânquias dos peixes. Assim, o peixe fica impedido de realizar as trocas gasosas entre a água e os tecidos das brânquias e morre por asfixia.

A maior contribuição para o meio ambiente, pela atividade humana, é a queima de combustíveis fósseis, além dos processos de mineração e fundição do metal, fusão e modelagem de ligas, indústrias de eletrodeposição e, como fontes secundárias, a fabricação de alimentos, artigos de panificadoras, refrigerantes e sorvetes aromatizados. Doses elevadas de níquel podem causar dermatites nos indivíduos mais sensíveis e afetar nervos cardíacos e respiratórios (CETESB, 2004b).

Em solos e sedimentos, o níquel precipita facilmente na superfície dos óxidos. Em ambientes ácidos, este elemento encontra-se ligado ao sulfato e, em meio levemente alcalino ( $\mathrm{pH}$ até 8), encontra-se na forma de carbonato e complexos orgânicos. Em sedimentos com considerável quantidade de matéria orgânica e elevados valores de $\mathrm{pH}$, o níquel pode ser encontrado como complexos orgânicos e ligado a carbonatos, predominando as espécies $\mathrm{NiCO}_{3}$ 
e $\mathrm{NiHCO}_{3}{ }^{+}$, e estes são susceptíveis à absorção pelas plantas e a lixiviação (REIS, 2002).

\subsubsection{Zinco $(\mathrm{Zn})$}

Metal lustroso, dúctil e maleável, o zinco apresenta coloração branca azulada, ocorre na forma livre ou combinada e é moderadamente abundante. Seus minérios mais comuns são smithsonita ou calamina $\left(\mathrm{ZnCO}_{3}\right)$, a zincita $(\mathrm{ZnO})$, a hemorfita $\left(\mathrm{Zn}_{4}(\mathrm{OH})_{2}\left(\mathrm{Si}_{2} \mathrm{O}_{7}\right) \cdot \mathrm{H}_{2} \mathrm{O}\right.$ e a esfarelita ou blenda $(\mathrm{ZnS})$, tendo este último maior importância comercial. O zinco é bastante utilizado em galvanoplastias e ligas metálicas, além de pilhas e baterias, em indústrias de tintas e borrachas, entre outros (LEE, 1996).

O zinco é um elemento essencial e benéfico para o metabolismo humano quando em quantidades adequadas, pois a atividade da insulina e diversos compostos enzimáticos dependem da sua presença e a deficiência deste metal nos animais pode conduzir ao atraso no crescimento. No entanto, se torna prejudicial à saúde quando ingerido em concentrações muito altas, o que é extremamente raro. Assim como outros metais, o zinco pode entrar nos ambientes aquáticos através de processos naturais e antropogênicos, pois este metal é largamente utilizado nas indústrias. Concentrações de zinco acima de $5,0 \mathrm{mgL}^{-1}$ conferem sabor metálico ou adstringente e uma aparência leitosa à água. Os efeitos tóxicos do zinco sobre os peixes e algas são muito conhecidos, a ação dos íons deste metal sobre o sistema respiratório dos peixes é semelhante à do níquel, anteriormente citada. No ser humano, o zinco pode acumular-se em alguns tecidos do organismo, bem como causar distúrbios gastrintestinais e diarréias, porém isso só ocorra em taxas de ingestão diária e elevadas (CETESB, 2004b).

Nas águas superficiais, o zinco ocorre mais comumente na forma de $\mathrm{Zn}^{2+}$, onde forma hidretos iônicos, carbonatos e complexos com compostos orgânicos. A sorção é o destino dominante do zinco em ambientes aquáticos, e ocorre por meio dos óxidos e hidróxidos de ferro e manganês, argilo-minerais e 
matéria orgânica. Em pH abaixo de 7, este metal é facilmente sorvido e apresenta grande mobilidade (ANJOS, 2003).

Em solos e sedimentos com pH próximo de 7, o zinco se hidrolisa e é facilmente adsorvido pela argila, carbonatos ou óxidos. Em condições aeróbias, o $\mathrm{Zn}^{2+}$ [e predominante para $\mathrm{pH}$ ácido e nas condições anaeróbias forma $\mathrm{ZnS}$ em valores de $\mathrm{pH}$ entre 1 e 14. Com a matéria orgânica, o zinco pode formar quelatos juntamente aos os ácidos fúlvicos (fulvatos de zinco) sob uma grande variedade de $\mathrm{pH}$, o que favorece o aumento da sua solubilidade e mobilidade no sistema. (QUINÁGLIA, 2001; ANJOS, 2003).

\subsection{Pesticidas Organoclorados}

Pesticidas são compostos orgânicos ou inorgânicos utilizados principalmente como defensivos agrícolas para a prevenção ou destruição de pragas e doenças, além de encontrar aplicação nas indústrias e em ambientes domésticos e urbanos. Estes compostos são classificados como: inseticidas, fungicidas, herbicidas, rodenticidas, acaricidas e nematocidas, entre outros. Muitos pesticidas são altamente tóxicos ao homem e a outros animais, seja por exposição direta, ou por acumulação no organismo via ingestão de alimentos contaminados (REZENDE, 1999; LARA, 1992).

Dentre os pesticidas, os organoclorados foram usados em grandes quantidades na década de 40, por sua eficiência como defensivos agrícolas e em campanhas de saúde pública, especialmente contra vetores do tifo e da malária. Os compostos organoclorados são hidrocarbonetos clorados que apresentam larga aplicação industrial e estão presentes em pesticidas, solventes, plásticos e outros produtos químicos, mostrando-se muito estáveis e degradando-se lentamente pelos processos naturais, podendo permanecer durante anos no meio ambiente.

Nos ecossistemas aquáticos, muitos organoclorados de alta massa molar causam grandes impactos. Devido à baixa solubilidade em água, esses contaminantes orgânicos se associam aos sedimentos, plantas, peixes, 
plânctons, entre outros, e tendem a se acumular nos tecidos graxos da maioria dos animais. A própria cadeia alimentar tende a aumentar o efeito concentrador dos organoclorados em cada etapa. São compostos relativamente inertes quando comparados a outras classes de pesticidas, pois apresentam alta estabilidade devido às ligações carbono-cloro. Entretanto, são conhecidos por sofrerem desidrocloração, oxidação, desclorinação, rearranjo, hidrólise e reações fotoquímicas (MORAES, 2003; AHMAD et al., 1999; CHAU; AFGHANM, 1982).

Em comum, todos os pesticidas organoclorados são relativamente inertes frente a ácidos e bases, e sob a luz solar sofrem reações químicas formando compostos com estabilidade similar ou maior que os compostos de origem (DINELLI; VICARI; CATIZONE, 1996; WERF; HAYO, 1996). De uma maneira geral, a poluição por compostos organoclorados no ambiente deve-se a descargas de efluentes não tratados, derramamentos acidentais ou intencionais e fontes não pontuais de contaminação, como drenagem urbana e agrícola, o que acarreta o comprometimento da qualidade de águas superficiais e subterrâneas e de solos (MORAES, 2003; WERF; HAYO, 1996).

Por serem persistentes, os compostos organoclorados se tornaram substâncias de interesse internacional, e no ano de 2001, na convenção de Estocolmo, foram tomadas as primeiras providencias em nível mundial do uso e produção destas substâncias, onde inicialmente doze compostos foram selecionados (aldrin, endrin, dieldrin, clordano, DDT, toxafeno, mirex, heptacloro, hexaclorobenzeno, PCB, dioxinas e furanos). Estes compostos compõem uma subclasse conhecida como POP (Poluentes Orgânicos Persistentes), os quais, juntamente com outras substâncias que satisfazem os critérios de persistência e toxicidade, compõem o grupo das STP (Substâncias Tóxicas Persistentes) (OLIVARES, 2006).

No Brasil, a utilização de pesticidas no controle de pragas e na agricultura aumentou nos últimos anos, tomando o lugar de ervas daninhas, que são inimigas naturais. A substituição por compostos sintéticos aumentou a produtividade agrícola na década de 50, no entanto, o uso destes compostos causou uma maior resistência das pragas pelos mesmos e, para manter a alta 
produtividade agrícola, a produção de pesticidas sintéticos aumentava a cada ano por este setor (ALMEIDA, 2004; OLIVARES, 2006).

Assim, o uso descontrolado somado à desinformação sobre os riscos oferecidos por estes compostos resultou em conseqüências imprevisíveis. A população rural foi a mais afetada por estes venenos nas décadas de 60 e 70, onde centenas de pessoas morreram devido à intoxicação por pesticidas. Neste período, os pesticidas clorados foram utilizados para uma variedade de fins, como o controle de insetos na agricultura, transmissores de doenças (malária e dengue), entre outros (ALMEIDA, 2004; OLIVARES, 2006).

A primeira portaria que definiu o uso destes compostos no Brasil foi a portaria no 10/SNVS de 08/03/1985. Nesta portaria, é atribuída à DINAL (Divisão Nacional de Vigilância Sanitária de Alimentos) a elaboração da relação de substâncias com ação tóxica sobre animais ou plantas, cujo registro pode ser autorizado no Brasil em atividades agropecuárias e em produtos domissanitários (ALMEIDA, 2004; OLIVARES, 2006).

A portaria ํㅜ 329/MA de 02/07/1985, proíbe em todo território nacional, a comercialização, uso e a distribuição dos produtos agrotóxicos organoclorados destinados à agropecuária (dentre eles: aldrin, $\mathrm{HCH}$, DDT, endrin, heptacloro, lindano e endossulfan), mas permite o uso de aldrin em iscas formicidas e cupinicidas para florestamento e reflorestamento, em campanhas de saúde pública de combate a vetores de agentes etiológicos de moléstia e o uso emergencial na agricultura (ALMEIDA, 2004; OLIVARES, 2006).

Em 1988, a Portaria no153 de 07/07/1988 alterou a Portaria 329 e autorizou a comercialização, o uso e a distribuição destes compostos, em caráter emergencial na agricultura, além do uso e da distribuição quando destinados exclusivamente à preservação de madeiras, em conformidade com as normas a serem estabelecidas pelo IBDF - Instituto Brasileiro de Desenvolvimento Florestal (ALMEIDA, 2004; OLIVARES, 2006).

A portaria do Ministério da Saúde (no 11/SVS-MS de 08/01/1998) exclui algumas substâncias da relação de substâncias com ação tóxica sobre animais ou plantas, cujo registro pode ser autorizado no Brasil, em atividades agropecuárias e produtos domissanitários, sendo estas: aldrin, $\mathrm{HCH}, \mathrm{DDT}$, endrin, heptacloro, lindano; lembrando que o uso como preservante de madeira 
ainda é permitido para todas as substâncias que se enquadram nesta função (ALMEIDA, 2004; OLIVARES, 2006). 
Tabela 5: Concentrações limites de compostos organoclorados em solos e sedimentos. Valores estabelecidos por diferentes fontes ${ }^{1}$.

\begin{tabular}{|c|c|c|c|c|c|c|c|c|c|c|}
\hline \multirow[t]{2}{*}{ Padrões } & \multicolumn{2}{|c|}{$\begin{array}{c}\text { CETESB } \\
\text { (CETESB, 2005) }\end{array}$} & \multicolumn{3}{|c|}{$\begin{array}{l}\text { Lista Holandesa }{ }^{2}-6530 \\
\text { (CETESB, 1999) }\end{array}$} & \multicolumn{3}{|c|}{$\begin{array}{l}\text { Lista Holandesa }{ }^{3}-6530 \\
\text { (CETESB, 1999) }\end{array}$} & \multicolumn{2}{|c|}{$\begin{array}{c}\text { Canadian Sediment } \\
\text { Quality - SQG } \\
\text { (CCME, 2002) }\end{array}$} \\
\hline & VRQ & VP & VR (S) & VA (T) & VI (I) & VR (S) & VA (T) & VI (I) & ISQG & PEL \\
\hline$\alpha-\mathrm{HCH}$ & - & - & $0,5 \mathrm{ppb}$ & \multirow{4}{*}{$\begin{array}{c}\text { Soma } \\
0,2 \mathrm{ppm}\end{array}$} & \multirow{4}{*}{$\begin{array}{c}\text { Soma } \\
0,4 \mathrm{ppm}\end{array}$} & $2,5 \mathrm{ppb}$ & \multirow{4}{*}{$\begin{array}{l}\text { Soma } \\
1 \text { ppm }\end{array}$} & \multirow{4}{*}{$\begin{array}{l}\text { Soma } \\
2 \text { ppm }\end{array}$} & - & - \\
\hline$\beta-\mathrm{HCH}$ & - & $11 \mathrm{ppb}$ & $0,2 \mathrm{ppb}$ & & & $1 \mathrm{ppb}$ & & & - & - \\
\hline$\gamma-\mathrm{HCH}$ & - & $1 \mathrm{ppb}$ & $0,01 \mathrm{ppb}$ & & & $0,05 \mathrm{ppb}$ & & & $0,32 \mathrm{ppb}$ & $0,99 \mathrm{ppb}$ \\
\hline$\delta-\mathrm{HCH}$ & - & - & - & & & - & & & - & - \\
\hline Heptacloro & - & - & - & - & - & - & - & - & - & - \\
\hline Heptacloro epóxido & - & - & - & - & - & - & - & - & $0,60 \mathrm{ppb}$ & $2,74 \mathrm{ppb}$ \\
\hline$\alpha$-Endosulfan & - & - & - & - & - & - & - & - & - & - \\
\hline$\beta$-Endosulfan & - & - & - & - & - & - & - & - & - & - \\
\hline Endosulfan sulfato & - & - & - & - & - & - & - & - & - & - \\
\hline Aldrin & - & $1,5 \mathrm{ppb}$ & $0,5 \mathrm{ppb}$ & \multirow{5}{*}{$\begin{array}{c}\text { Soma } \\
0,4 \mathrm{ppm}\end{array}$} & \multirow{5}{*}{$\begin{array}{l}\text { Soma } \\
0,8 \mathrm{ppm}\end{array}$} & $2,5 \mathrm{ppb}$ & \multirow{5}{*}{$\begin{array}{l}\text { Soma } \\
2 \text { ppm }\end{array}$} & \multirow{5}{*}{$\begin{array}{l}\text { Soma } \\
4 \text { ppm }\end{array}$} & - & - \\
\hline Dieldrin & - & $43 \mathrm{ppb}$ & $0,1 \mathrm{ppb}$ & & & $0,5 \mathrm{ppb}$ & & & $0,71 \mathrm{ppb}$ & $4,30 \mathrm{ppb}$ \\
\hline Endrin & - & $1 \mathrm{ppb}$ & $0,2 \mathrm{ppb}$ & & & $1 \mathrm{ppb}$ & & & 2,67 ppb & $62,40 \mathrm{ppb}$ \\
\hline Endrin aldeído & - & - & - & & & - & & & - & - \\
\hline Endrin cetona & - & - & - & & & - & & & - & - \\
\hline$p, p-D D D$ & - & $13 \mathrm{ppb}$ & \multirow{3}{*}{$\begin{array}{c}\text { Soma } \\
0,5 \mathrm{ppb}\end{array}$} & \multirow{3}{*}{$\begin{array}{c}\text { Soma } \\
0,4 \text { ppm }\end{array}$} & \multirow{3}{*}{$\begin{array}{c}\text { Soma } \\
0,8 \mathrm{ppm}\end{array}$} & \multirow{3}{*}{$\begin{array}{l}\text { Soma } \\
2,5 \mathrm{ppb}\end{array}$} & \multirow{3}{*}{$\begin{array}{l}\text { Soma } \\
2 \text { ppm }\end{array}$} & \multirow{3}{*}{$\begin{array}{l}\text { Soma } \\
4 \text { ppm }\end{array}$} & 1,22 ppb & 7,81 ppb \\
\hline$p, p-D D E$ & - & $21 \mathrm{ppb}$ & & & & & & & $2,07 \mathrm{ppb}$ & $3,74 \mathrm{ppb}$ \\
\hline p,p-DDT & - & $10 \mathrm{ppb}$ & & & & & & & $1,19 \mathrm{ppb}$ & $4,77 \mathrm{ppb}$ \\
\hline$\alpha$-Clordano & - & - & - & - & - & - & - & - & $26 n n h$ & $79 \mathrm{nnh}$ \\
\hline$\gamma$-Clordano & - & - & - & - & - & - & - & - & 2,26 ppb & 4,79 ppb \\
\hline
\end{tabular}

${ }^{1}$ As abreviaturas constam no início deste trabalho, na lista de abreviaturas;

${ }^{2}$ Lista Holandesa - valores de referência para solo com $0 \%$ de matéria orgânica;

${ }^{3}$ Lista Holandesa - valores de referência para solo com $10 \%$ de matéria orgânica. 


\subsubsection{Ciclodienos}

Diversos hidrocarbonetos cíclicos clorados formam uma classe de compostos conhecida como pesticidas ciclodienos. Entre eles pode-se destacar aldrin, dieldrin, endrin, heptacloro, heptacloro epóxido, clordano, endosulfan, entre outros.

Aldrin (figura 11a) e dieldrin (figura 11b) são inseticidas de estrutura similar, que foram bastante utilizados nas décadas de 50 e 70 em diversos tipos de plantações, como por exemplo, milho e algodão. $\mathrm{O}$ aldrin foi usado no controle de besouros, cupim (ou formiga branca) e outras pragas encontradas em raízes. O dieldrin foi empregado diretamente nos solos e semente, e na saúde pública, para controlar vetores de doenças como mosquitos e moscas. Devido a sua persistência, dieldrin também pode ser encontrado em peixes, frutos do mar, laticínios, carnes gordurosas e raízes (GHISELLI, 2001; ATSDR, 2006, IPCS, 2006).

Estes compostos não ocorrem naturalmente no ambiente e, quando puros, apresentam-se como sólidos brancos de odor suave. Comercialmente, apresentam coloração marrom clara. São solúveis na maioria dos solventes orgânicos (aromáticos, ésteres, cetonas, parafinas e halogenados) e, praticamente insolúveis em água (GHISELLI, 2001; IPCS, 2006).

No organismo e no ambiente (plantas e animais), o aldrin é rapidamente convertido em dieldrin. Este, por sua vez, degrada-se muito lentamente e geralmente é absorvido e estocado pelas plantas ou encontrado nos tecidos que apresentam alto teor de lipídeos (GHISELLI, 2001; ATSDR, 2006; IPCS, 2006).

O pesticida endrin (figura 11c) e seus subprodutos endrin aldeído (figura 11d) e endrin cetona (figura 11e), também são classificados como inseticidas organoclorados. São solúveis na maioria dos solventes orgânicos, principalmente os halogenados e, praticamente insolúveis em água. 
Os pesticidas organoclorados da classe dos drins apresentam toxicidades muito parecidas, afetando o sistema nervoso central, a toxicidade aguda de aldrin e dieldrin resultam em convulsão e morte e a toxicidade crônica pode causar mal-estar, perda de apetite, dores de cabeça, tontura, náusea, vômitos, diarréias, problemas renais, tremores, convulsões seguidas de depressão e falhas respiratórias. O endrin é bastante tóxico para peixes e a toxicidade crônica pode causar convulsões epiléticas, dores de cabeça, tontura, náusea, vômitos, insônia e anorexia (GHISELLI, 2001; ATSDR, 2006; IPCS, 2006).

Os efeitos da exposição prolongada contendo baixos níveis destes compostos não são totalmente conhecidos, mas alguns estudos apontaram sintomas como dores de cabeça, diarréia, vômitos, irritabilidade, movimentos incontroláveis dos músculos, problemas hepáticos, etc. Estudos com animais mostraram que estes compostos afetam também o sistema imunológico, diminuindo a resistência às infecções. A Agência Internacional de Pesquisa sobre o Câncer não classifica o aldrin e o dieldrin como sendo compostos cancerígenos para humanos, podendo ser classificados como potencialmente cancerígenos. Para os compostos endrin cetona e endrin aldeído, embora considerados como subprodutos do endrin, quase nenhuma informação técnica pôde ser encontrada, principalmente com relação às suas toxicidades (GHISELLI, 2001; ATSDR , 2006; IPCS, 2006).

O clordano (figura $11 \mathrm{f}$ e 12), o heptacloro (figura 11g) e o heptacloro epóxido (figura 11h) são inseticidas organoclorados de estruturas relacionadas, o produto de cada um contem entre 10 a $20 \%$ do outro composto. Foram usados desde 1950 para o controle da térmita, em colheitas agriculturas, em gramados, em animais domésticos e para outras finalidades. Seu uso tem sido proibido atualmente ou restringido severamente em muitos países, onde a exposição humana ainda é possível devido a sua persistência no ambiente e a sua ocorrência conseqüente na carne, nos peixes e em outros gêneros alimentícios gordurosos (IPCS, 2006).

O clordano é metabolizado primeiramente ao oxiclordano e, a uma extensão menor, pode também ser metabolizado ao heptacloro. O heptacloro, 
que é também um componente do clordano, é biotransformado em seu epóxido. A exposição acidental ou intencional ao clordano resultou nos sinais do neurotoxicidade e, em alguns casos, a morte.

Os inseticidas e acaricidas endosulfan (figura 11i e 12) e endosulfan sulfato (figura 11j) apresentam expressivas toxicidades em ambientes aquáticos. O endosulfan está sendo bastante utilizado no Manejo Integrado de Pragas (MIP) em soja, bem como em culturas de algodão, cacau e café, tendo seu uso mais recentemente liberado para cana-de-açúcar. Este composto é altamente tóxico aos peixes, promovendo desordens metabólicas e reprodutivas. Seres humanos contaminados por endosulfan possuem os sintomas de irritabilidade, convulsões e desordens neurológicas e, este composto pode ser absorvido através do trato gastrintestinal, por inalação ou pelo contato com a pele (ARAÚJO, 1999).

\subsubsection{DDT e Subprodutos}

O DDT (figura 11k) ocorre naturalmente no ambiente e foi primeiramente sintetizado por Zeidler em 1874, entretanto, começou a ser utilizado apenas em 1939, quando Paul Muller descobriu suas propriedades inseticidas. Durante muitos anos foi utilizado, principalmente pelos EUA, no controle da malaria em áreas militares. Sua estrutura permite várias formas isoméricas e todos os seus isômeros são brancos, cristalinos, não apresentam gosto e em sua maioria são sólidos inodoros (GHISELLI, 2001; IPCS, 2006).

O DDT pode ser facilmente convertido em DDE (figuras 11l) e em DDD (figura $11 \mathrm{~m}$ ) quando em meio alcalino, principalmente em temperaturas acima do seu ponto de fusão e na presença de catalisador ou luz. Nas soluções contendo solventes orgânicos esta conversão é favorecida por bases orgânicas ou alcalinas.

Assim como os drins, o DDT e seus subprodutos afetam principalmente o sistema nervoso central e periférico. A toxicidade crônica ao DDT inclui neuropatia periférica, fraqueza muscular, ansiedade, tensão, medo, perda de 
peso, tremores e anemia. Reações alérgicas também têm sido relatadas aos compostos DDT, além de causarem dores de cabeça, vertigem, sonolência, mal-estar geral, irritabilidade, náusea, perda de apetite e vômitos. Estes sintomas são conseqüências da sua acumulação no tecido adiposo (GHISELLI, 2001; IPCS, 2006).

\subsubsection{Hexaclorociclohexano}

Em algumas regiões do Brasil, no fim da década de 40, 0 hexaclorociclohexano $(\mathrm{HCH}$, figura $11 n)$ foi usado para o controle da doença de Chagas e da malária, mas sua mais ampla aplicação foi na agricultura para o controle de pragas nas plantações de café, algodão e soja. A síntese do $\mathrm{HCH}$ é baseada na adição sucessiva de cloro ao benzeno, tendo como produtos os isômeros $\alpha-\mathrm{HCH}, \beta-\mathrm{HCH}, \delta-\mathrm{HCH}$ e o $\gamma-\mathrm{HCH}$ (figura 12) em diferentes percentuais estequiométricos. $\mathrm{O} \gamma-\mathrm{HCH}$ é o isômero que apresenta maiores propriedades inseticidas, sendo conhecido comercialmente como lindano.

Os $\mathrm{HCH}$ são volatilizados com facilidades na atmosfera, quando aplicados em grandes quantidades nas áreas tropicais. Esses compostos são de grande preocupação, pois se apresentam muito estáveis no meio ambiente sob altas temperaturas. São apolares bem como outros organoclorados, portanto possuem baixa solubilidade em água e são mais encontrados em sedimentos, animais e plantas quando em ecossistemas aquáticos.

Os HCH são possíveis carcinogênicos e a contaminação nos humanos pode ocorrer de forma aguda ou crônica, por meio das vias dérmica, respiratória ou alimentar. São compostos altamente tóxicos, lipofílicos e persistentes, sendo absorvidos e armazenados nos tecidos gordurosos, podendo causar danos ao sistema nervoso central (OLIVEIRA et al., 2003). 
<smiles>ClC1=C(Cl)C2(Cl)C3CCC(C3)C1C2(Cl)Cl</smiles>

(a)

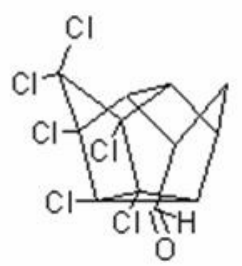

(d)<smiles>ClC1=C(Cl)C2(Cl)C3C(Cl)C=CC3C1(Cl)C2(Cl)Cl</smiles>

(g)<smiles>ClC1=C(Cl)C2(Cl)C3C(C4CC3C4(Cl)Cl)C1C2(Cl)Cl</smiles>

(b)

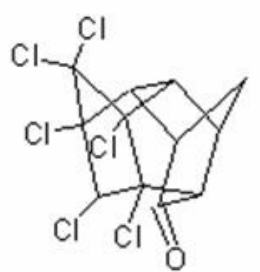

(e)<smiles>ClC1=C(Cl)C2(Cl)C3C4OC4C(Cl)C3C1(Cl)C2(Cl)Cl</smiles>

(h)<smiles>ClC1=C(Cl)C2(Cl)C3C(C4CC3C4(Cl)Cl)C1C2(Cl)Cl</smiles>

(c)<smiles>ClC1C2C3CC(Cl)C(Cl)(C3Cl)C(Cl)(C1Cl)C2(Cl)Cl</smiles>

(f)

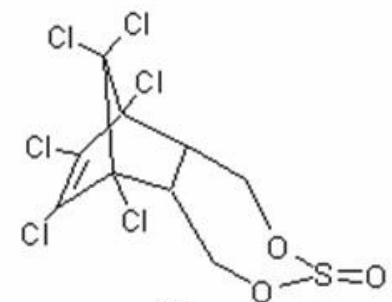

(i)<smiles>O=[SH]1(O)OCC2C(CO[SH](=O)(O)O1)C1(Cl)C(Cl)=C(Cl)C2(Cl)C1(Cl)Cl</smiles><smiles>Clc1ccc(C(c2ccc(Cl)cc2)C(Cl)(Cl)Cl)cc1</smiles>

(k)<smiles>ClC(Cl)=C(c1ccc(Cl)cc1)c1ccc(Cl)cc1</smiles>

(I)<smiles>Clc1ccc(C(c2ccc(Cl)cc2)C(Cl)Cl)cc1</smiles>

(m)

Figura 11: Estruturas dos seguintes compostos organoclorados: (a) Aldrin; (b) Dieldrin; (c) Endrin; (d) Endrin Aldeído; (e) Endrin Cetona; ( $f$ Clordano; (g) Heptacloro; (h) Heptacloro Epóxido; (i) Endosulfan; (j) Endosulfan Sulfato; (k) p,p-DDT; (l) p,p-DDE; (m) p,p-DDD e (n) Hexaclorociclohexano. 
<smiles>ClC1=C(Cl)C2(Cl)C3C(CC(Cl)C3(Cl)Cl)C1(Cl)C2(Cl)Cl</smiles>

$\alpha$-Clordano<smiles>O=S1OCC2C(COS1)C1(Cl)C(Cl)=C(Cl)C2(Cl)C1(Cl)Cl</smiles>

$\alpha$ Endosulfan<smiles>ClC1C(Cl)C2C(Cl)C(Cl)C1C(Cl)C2Cl</smiles>

$\alpha-\mathrm{HCH}$<smiles>ClC1C2C(Cl)C(Cl)C(Cl)(C1Cl)C2Cl</smiles>

$\gamma-\mathrm{HCH}$<smiles>ClC1=C(Cl)C2(Cl)C(Cl)C1(Cl)C1CC3(Cl)C(Cl)=C(Cl)C3(Cl)C12</smiles>

$\beta$-Clordano<smiles>O=S1(=O)OCC2C(COS(=O)(=O)C3(Cl)C(Cl)=C(Cl)C2(Cl)C3(Cl)Cl)O1</smiles>

$\beta$ Endosulfan<smiles></smiles>

$\beta-\mathrm{HCH}$<smiles>ClC1C(Cl)C2C(Cl)C1C2(Cl)Cl</smiles>

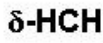

Figura 12: Isômeros de alguns dos compostos organoclorados deste estudo. 


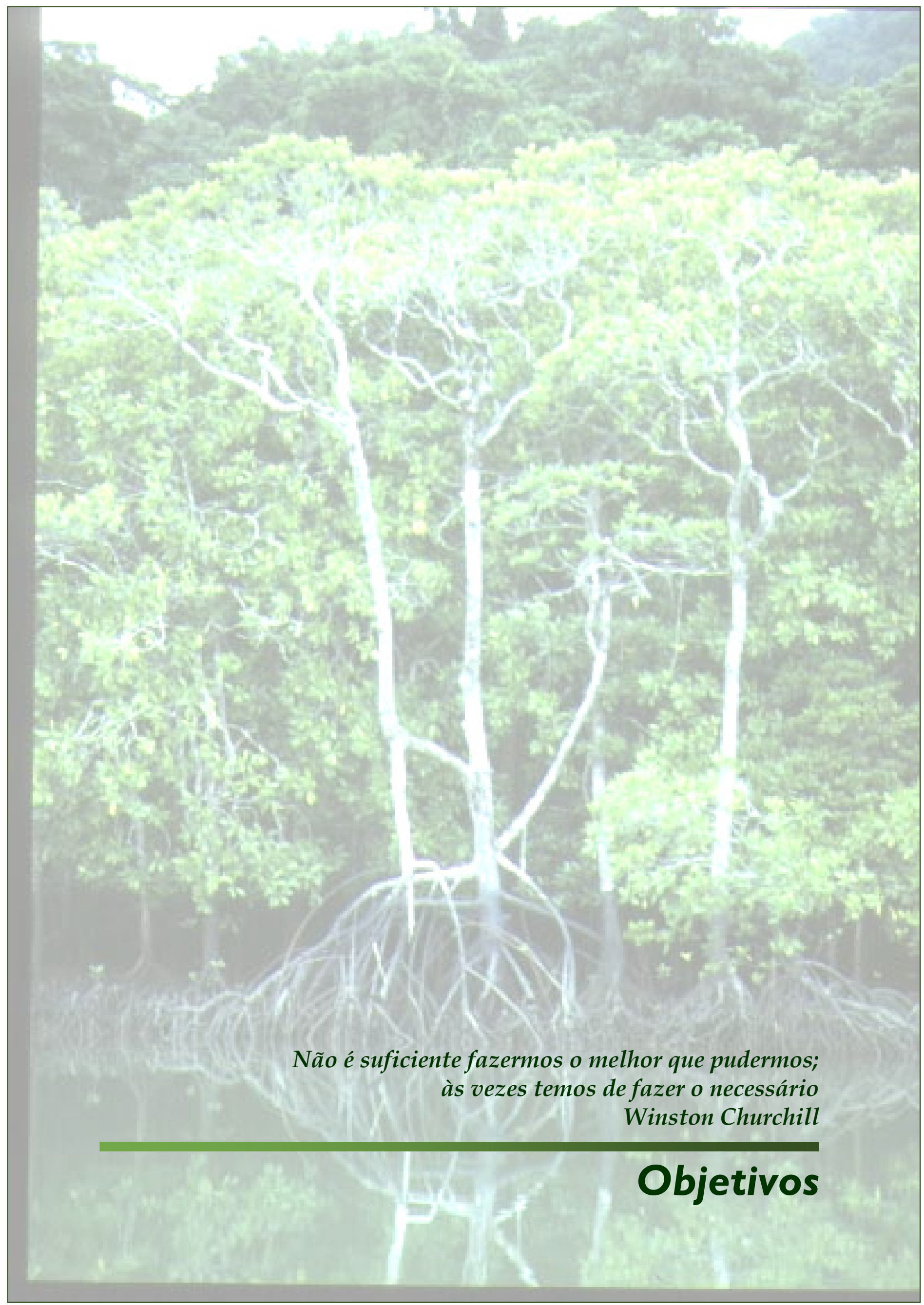




\section{OBJETIVOS}

O presente projeto de pesquisa teve como objetivo diagnosticar áreas de manguezais de duas regiões distintas localizadas no litoral sudeste do estado de São Paulo, no que diz respeito a metais e compostos organoclorados. Uma destas áreas abrange parte dos mangues da Baixada Santista, envolvendo os municípios de São Vicente, Santos, Guarujá e Cubatão, enquanto a outra engloba os mangues do complexo estuarino de Cananéia-Iguape. Dentre os objetivos estão:

1. A determinação da concentração de 10 metais pseudo-totais por ICP-AES em amostras de sedimento, água e plantas dos manguezais citados;

2. A determinação da concentração de 19 pesticidas organoclorados por GCECD em amostras de sedimento e plantas dos manguezais citados;

3. A determinação do teor de ácidos húmicos e do teor de carbono orgânico total em amostras de sedimento dos manguezais citados;

4. A caracterização das amostras de água e sedimento e a relação destes parâmetros com as concentrações dos analitos deste estudo. 


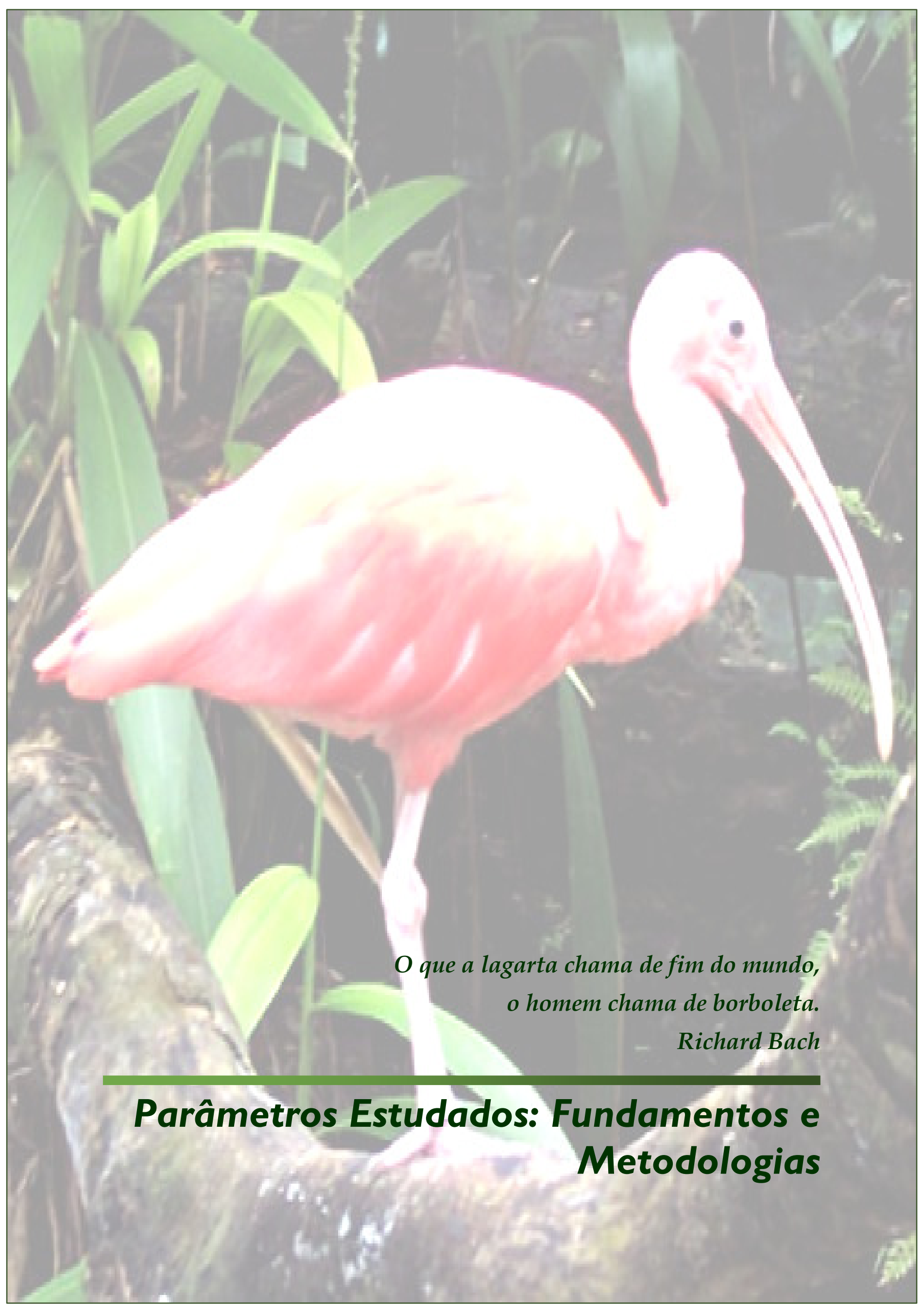




\section{PARÂMETROS ESTUDADOS: FUNDAMENTOS E METODOLOGIAS}

\subsection{Amostragem}

A metodologia utilizada para a realização da investigação de uma área, com a finalidade de estudar uma possível contaminação, é constituída basicamente pela coleta de amostras (solo e/ou água) em pontos estrategicamente posicionados e a realização de análises seguida da interpretação dos resultados pela comparação dos valores de concentração obtidos com os valores estabelecidos em lista de padrões, definida pelo órgão responsável pelo gerenciamento da área em questão (CETESB, 2001b).

A coleta de amostras é feita através de métodos de amostragem selecionados em função das características específicas do meio físico e dos contaminantes em cada área. Além da coleta nos pontos onde ocorre a maior probabilidade de existência de contaminação, devem ser tomadas também amostras onde não ocorra a influência das fontes suspeitas identificadas (CETESB, 2001b).

Amostras de água, sedimento e folhas e raízes de três espécies de mangues (Avicennia schaueriana, Laguncularia racemosa e Rhizophora mangle) foram coletadas em dez pontos distintos, sendo cinco pertencentes ao complexo estuarino da Baixada Santista e cinco pertencentes ao complexo estuarino de Cananéia. Na Baixada Santista as coletas foram realizadas nos dias 08 (pontos 1, 2 e 3) e 09 (pontos 4 e 5) de setembro de 2005 e, em Cananéia, no dia 04 de novembro de 2005. Todas as coletas foram feitas em horário de maré baixa, entre 10 e 12 horas da manhã.

As figuras 13 e 14 mostram algumas características das proximidades dos pontos de coleta, enquanto que as figuras 15 e 16 mostram esquematicamente os pontos de amostragem nos complexos estuarinos da Baixada Santista e de Cananéia respectivamente. A demarcação dos pontos foi feita em função de características circunvizinhas (indústrias, comunidades de palafitas, balsas, etc), as quais poderiam influenciar na concentração e distribuição dos analitos de estudo nos estuários. 
As amostras de sedimento foram coletadas em diversas porções em um mesmo ponto de amostragem, considerando-se a heterogeneidade do local, em uma profundidade de aproximadamente $20 \mathrm{~cm}$, utilizando-se frascos de polietileno (para análise de metais) e vidros âmbar (para análise de organoclorados) com bocas largas e tampas rosqueadas com septos de teflon. As amostras de águas superficiais, assim como para sedimentos, foram coletadas em diversas porções utilizando-se frascos de polietileno com e sem a adição de $\mathrm{HNO}_{3}$ até $\mathrm{pH}<2$ (para metais e caracterização, respectivamente). Por último, as amostras de raízes e folhas de mangues foram coletadas em sacos plásticos do tipo zip (para metais) e folhas de papel alumínio (para organoclorados). Em seguida todo o material devidamente separado e etiquetado, foi preservado em geleiras contendo gelo, conferindo um temperatura de aproximadamente $4{ }^{\circ} \mathrm{C}$ durante o trajeto e, ao chegar no laboratório, foram armazenadas em freezer com temperaturas inferiores a -10 $\stackrel{\circ}{ } \mathrm{C}$. Todas as amostras foram coletadas conforme as recomendações do Manual de Produtos Químicos elaborado pela CETESB (2003).

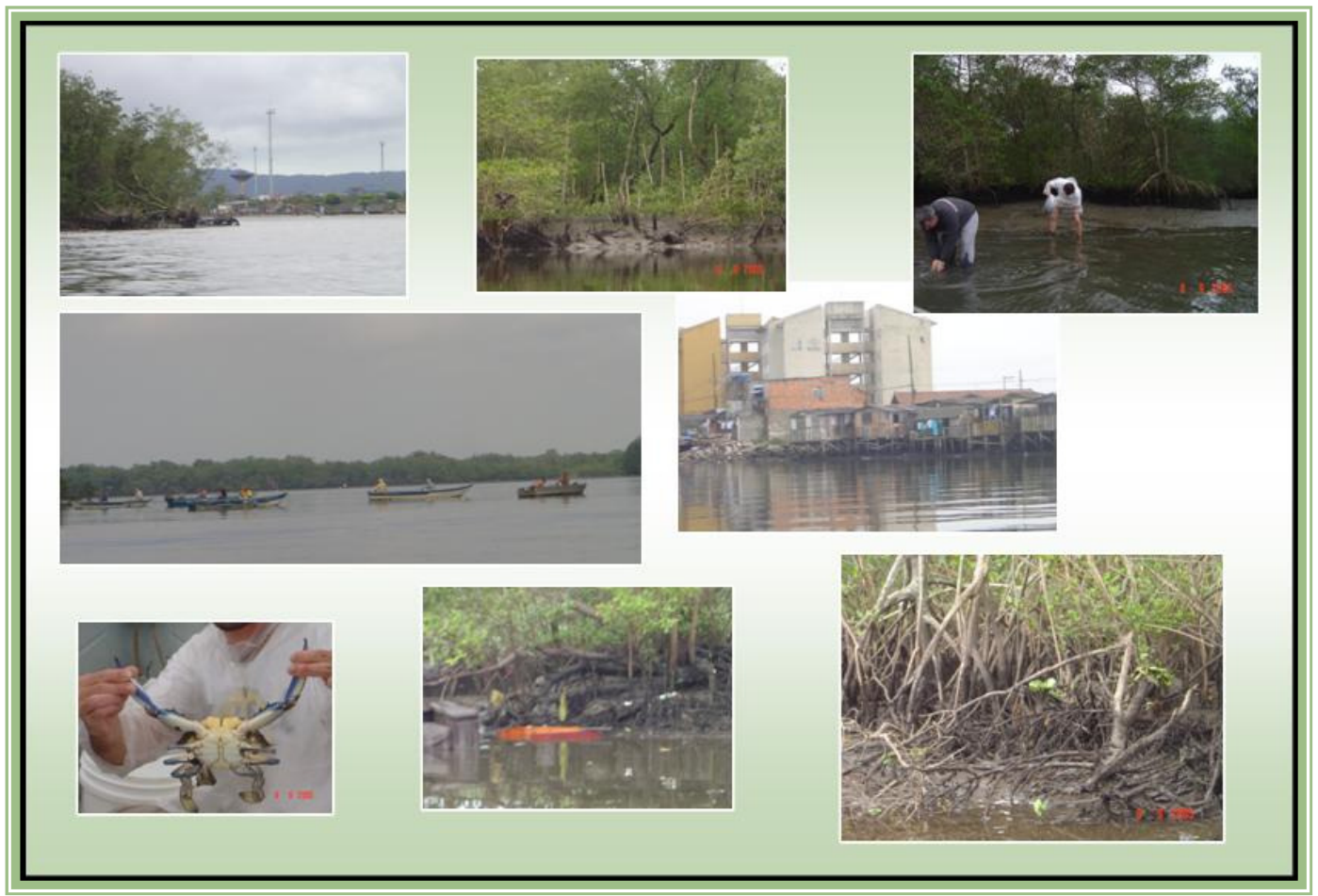

Figura 13: Algumas características das proximidades dos pontos de coleta - Baixada Santista, como: a presença de indústrias, palafitas e a disposição de lixo em contraste com a beleza dos mangues, a fauna e a atividade pesqueira. 


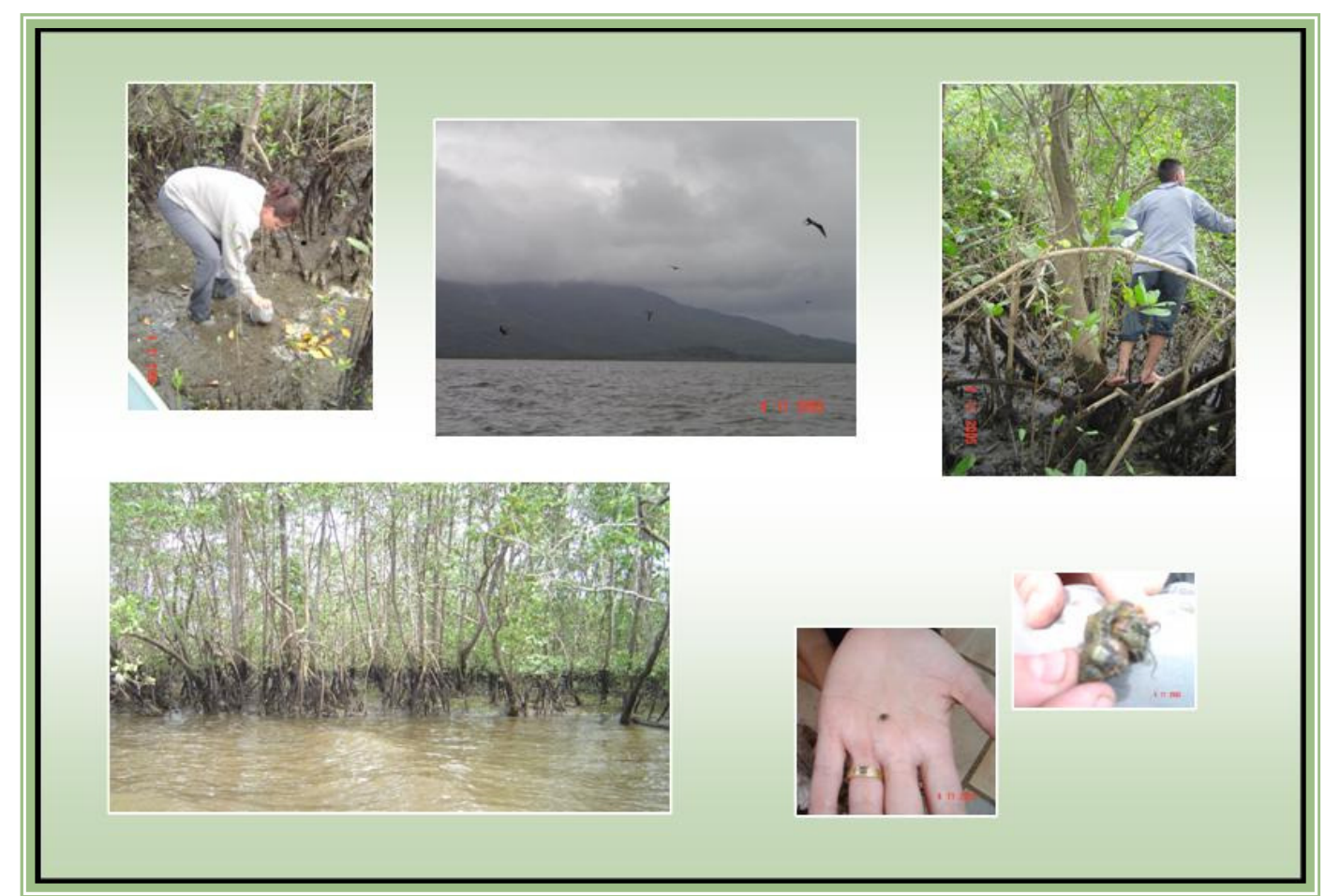

Figura 14: Algumas características das proximidades dos pontos de coleta - Cananéia, como a beleza da fauna e flora.

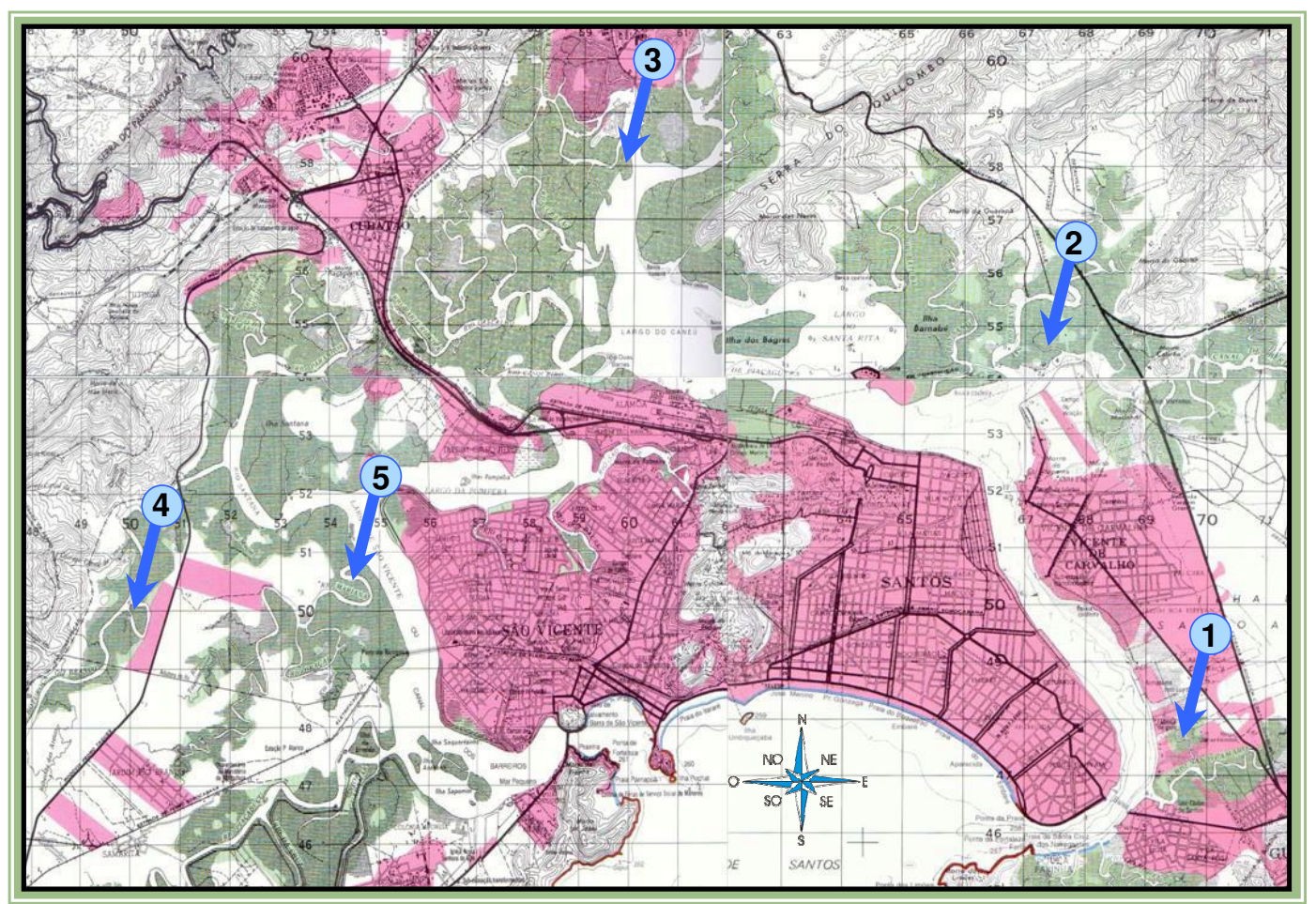

Figura 15: Pontos de coleta na Baixada Santista: (1) 235ㅇ'37,6"S-46ำ16'56,3”O - Guarujá; (2) 235' 58,9 "S-461'8,0"O - Santos; (3) 235'2, 6"S-4622'49,2"O - Cubatão;

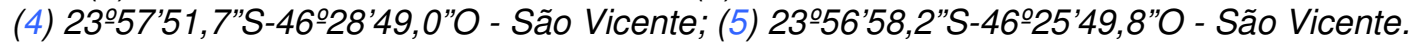




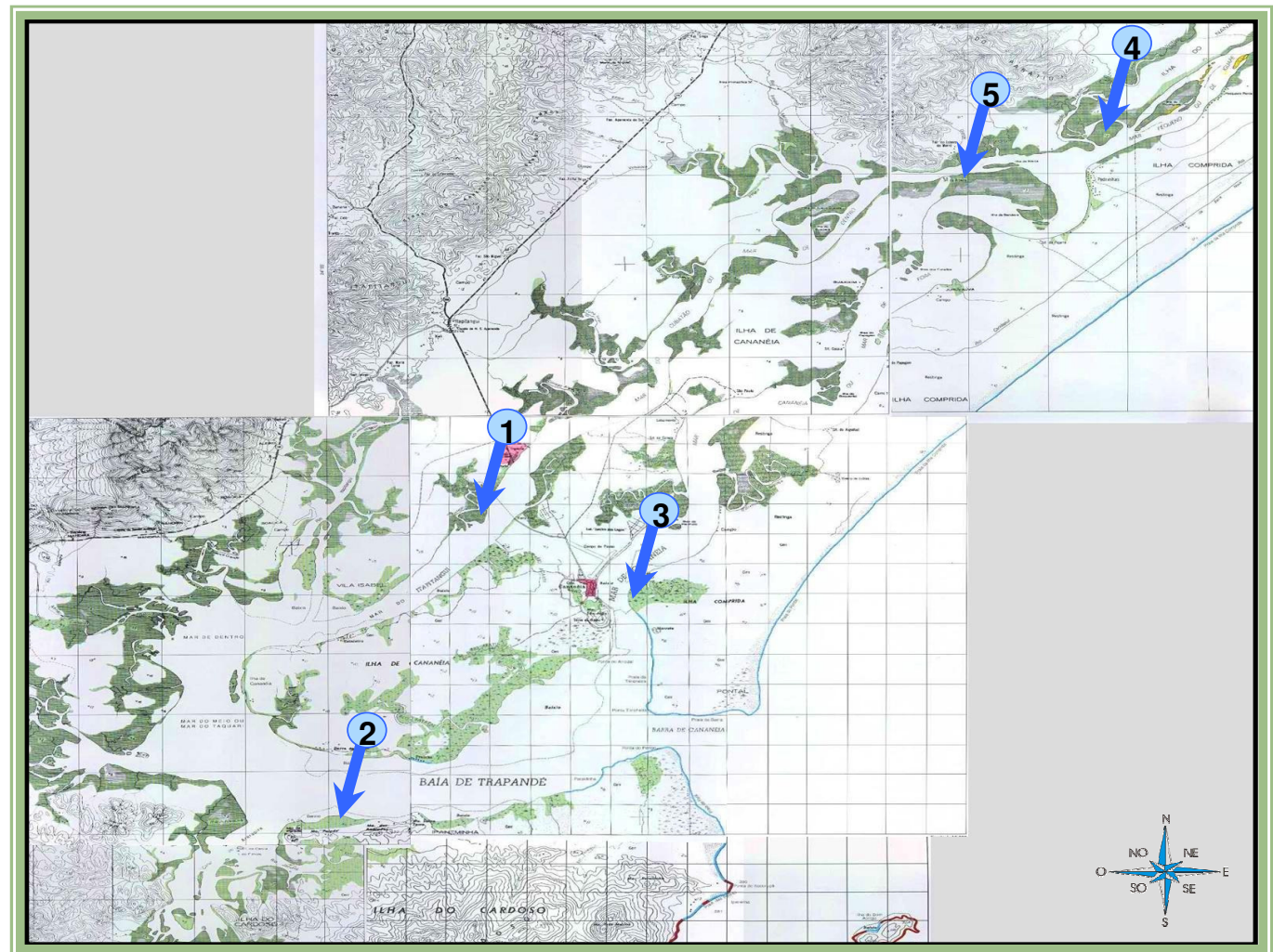

Figura 16: Pontos de coleta no Complexo Estuarino de Cananéia-Iguape:

(1) 2459'34,7"S-475'12,4"O - Cananéia; (2) 254'49,1"S-4759'24,1"O - Ilha do Cardoso;

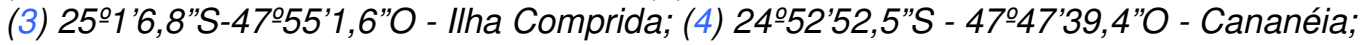

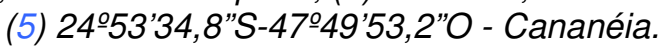

\subsection{Limpeza da Vidraria de Laboratório}

Ao trabalhar com amostras ambientais, pequenas concentrações de interferentes são significativas nos resultados, portanto a limpeza da vidraria se torna uma importante etapa do trabalho, a qual deve ser minuciosa.

Toda a vidraria foi limpa de acordo com o tipo de análise a qual iria se realizar. Assim, para as caracterizações de amostras de água e sedimento, a vidraria utilizada foi imersa em uma solução de detergente extran $2 \%$ pelo período de 24 horas e, em seguida, foi lavada e enxaguada sucessivamente com água corrente (dez vezes), água destilada (três vezes) e água milli-pore (uma vez).

Para a vidraria destinada às análises de compostos organoclorados, o procedimento de limpeza foi o mesmo citado para as caracterizações, no 
entanto com uma etapa a mais, onde a vidraria foi enxaguada com solvente orgânico (hexano). E no que diz respeito a vidraria destinada a determinação de metais, seguiu-se a mesma lavagem até a etapa de enxágüe com água destilada e, na seqüência, o material foi imerso em uma solução de $\mathrm{HNO}_{3} 20$ \% durante três dias e enxaguado posteriormente com água milli-pore. Todo o material foi seco em estufa, com exceção dos volumétricos.

\subsection{Caracterização das amostras de água}

As amostras de águas superficiais foram caracterizadas de acordo com os parâmetros: temperatura, salinidade, $\mathrm{pH}$, oxigênio dissolvido, condutividade e sólidos totais dissolvidos. Todas as determinações foram feitas em triplicatas.

\subsubsection{Temperatura da água $(\mathrm{T})$}

Variações de temperatura são parte do regime climático normal, e corpos d'água naturais apresentam variações sazonais e diurnas, bem como estratificação vertical. A temperatura desempenha um papel importante no meio aquático, condicionando as influências de uma série de parâmetros físicoquímicos como densidade da água, capacidade de saturação do oxigênio dissolvido, $\mathrm{pH}$, condutividade e, é influenciada por fatores tais como latitude, altitude, estação do ano, período do dia, taxa de fluxo e profundidade. Em geral, à medida que a temperatura aumenta, de 0 a $30^{\circ} \mathrm{C}$, a viscosidade, tensão superficial, compressibilidade, calor específico, constante de ionização e calor latente de vaporização diminuem, enquanto a condutividade térmica e a pressão de vapor aumentam. Organismos aquáticos possuem limites de tolerância térmica superior e inferior, temperaturas ótimas para crescimento, temperatura preferida em gradientes térmicos e limitações de temperatura para migração, desova e incubação do ovo (CETESB, 2004b).

No presente trabalho, foram obtidas três leituras para as medidas de temperatura em cada ponto de coleta. As medidas foram realizadas in situ com 
o auxílio do aparelho de campo Water - Checker Horiba, modelo U-10, que consiste em uma sonda com múltiplos sensores.

\subsubsection{Salinidade da água (S)}

As variações na salinidade limitam a colonização do substrato a espécies fisiologicamente adaptadas a diferentes pressões osmóticas. Deve-se ressaltar que há outros fatores muito importantes que interferem na salinidade e que, portanto, precisam ser observados. Valores altos e/ou baixos de salinidade devem ser correlacionados com os índices pluviométricos, a vazão dos rios e canais, a topografia da área de coleta, a temperatura do ar, a insolação, bem como o tempo de exposição da área durante as baixamarés (SCHAEFFER-NOVELLI; CINTRÓN, 1986).

As marés são o principal mecanismo de penetração das águas salinas nos manguezais e essas periódicas inundações tornam o substrato favorável a colonização pela vegetação de mangues, excluindo espécies de plantas que não suportam a presença de sal. A variação na freqüência de inundação do manguezal pelas marés, pode acarretar diferenças nas concentrações de sal e, de um modo geral, as maiores salinidades são encontradas em manguezais mais próximos ao mar e em contraste, menores concentrações em manguezais mais próximos dos rios (FERNANDES; PERIA, 1995; SOARES, 1995).

No entanto, em locais onde a maré chega poucas vezes ou onde há menor influencia de água doce (rios e/ou chuvas), as salinidades podem ser tão elevadas que nem mesmo as plantas de mangue conseguem crescer. Isto ocorre quando as marés, ao atingirem esses locais, levam água e sal e, com a evaporação, aumenta a concentração de sais, agravada por um reduzido aporte de água doce (SOARES, 1995).

Em cada ponto de coleta foram obtidas três leituras para as medidas de salinidade in situ com o auxílio do aparelho de campo Water - Checker Horiba, modelo U-10. 


\subsubsection{Potencial Hidrogeniônico da água $(\mathrm{pH})$}

$\mathrm{O}$ pH é um parâmetro importante em muitos estudos no campo do saneamento ambiental, uma vez que este interfere em diversos equilíbrios químicos que ocorrem naturalmente ou em processos unitários de tratamento de águas. Em ecossistemas aquáticos, determinadas condições de pH podem contribuir para a precipitação de elementos químicos tóxicos como, por exemplo, metais pesados; outras condições podem exercer efeitos sobre as solubilidades de nutrientes disponibilizando ou não estes para as plantas (CETESB, 2004b). Nos manguezais, valores muito baixos pode ser um fator limitante ao desenvolvimento de organismos que necessitem, por exemplo, de carbonato de cálcio para formação de conchas, carapaças, etc. (SCHAEFFERNOVELLI; CINTRÓN, 1986).

Desta forma, as restrições de faixas de $\mathrm{pH}$ são estabelecidas para as diversas classes de águas naturais, tanto de acordo com a legislação federal (Resolução no 357 de 17/03/2005, CONAMA), como pela legislação do Estado de São Paulo (Decreto no 8468/76). Os critérios de proteção à vida aquática fixam o pH entre 6 e 9 . Normalmente, a condição de $\mathrm{pH}$ que corresponde à formação de um ecossistema mais diversificado é a de neutralidade, tanto em meios aeróbios como nos anaeróbios (CETESB, 2004b).

Nas estações de tratamento de águas, são várias as unidades cujo controle envolve as determinações de $\mathrm{pH}$. Sabe-se que as águas ácidas são corrosivas, ao passo que as alcalinas são incrustantes, por isso o pH da água final deve ser controlado, para que os carbonatos presentes sejam equilibrados e não ocorra nenhum dos dois efeitos indesejados mencionados. $\mathrm{O} \mathrm{pH}$ é padrão de potabilidade, de emissão de esgotos e de efluentes líquidos industriais, tanto pela legislação federal quanto pela estadual (CETESB, 2004b).

Para as medidas de $\mathrm{pH}$ na água, foram obtidas três leituras in situ em cada ponto de coleta, utilizando-se o aparelho de campo Water - Checker Horiba, modelo U-10. 


\subsubsection{Oxigênio Dissolvido na água (DO)}

A presença de oxigênio na água é essencial para vários organismos nos processos metabólicos aeróbios, sejam bactérias ou outros grupos responsáveis pela degradação de poluentes nos sistemas aquáticos, os quais utilizam este elemento como receptor de elétrons (ROCHA; ROSA; CARDOSO, 2004). O oxigênio proveniente da atmosfera se dissolve nas águas naturais, devido à diferença de pressão parcial, onde a taxa de introdução deste através da superfície, depende das características hidráulicas, da temperatura e da altitude (CETESB, 2004b; GOLTERMAN; CLYMO; OHNSTAD, 1978).

Outra fonte importante de oxigênio nas águas é a fotossíntese de algas e plantas submersas, um fenômeno que ocorre em águas poluídas ou, mais propriamente, em águas em que a decomposição dos compostos orgânicos lançados levou à liberação de sais minerais no meio, especialmente os de nitrogênio e fósforo, que são utilizados como nutrientes pelas algas. A contribuição fotossintética de oxigênio só é expressiva após grande parte da atividade bacteriana na decomposição da matéria orgânica ter ocorrido, bem como após terem se desenvolvido também os protozoários que, além de decompositores, consomem bactérias clarificando as águas e permitindo a penetração de luz (CETESB, 2004b).

Através da medição do teor de DO, pode-se avaliar os efeitos de resíduos oxidáveis sobre águas receptoras e a eficiência do tratamento dos esgotos durante a oxidação bioquímica, bem como indicar a capacidade de um corpo d'água natural de manter a vida aquática (CETESB, 2004b).

Neste trabalho as medidas de DO foram realizadas através da tomada de três leituras in situ em cada ponto de coleta, utilizando-se o aparelho de campo Water - Checker Horiba, modelo U-10. 


\subsubsection{Condutividade da água (EC)}

A condutividade é a expressão numérica da capacidade que uma determinada amostra de água tem de conduzir a corrente elétrica. A condutividade depende das concentrações iônicas e da temperatura, e indica a quantidade de sais existentes na coluna d'água, representando algumas vezes portanto, uma medida indireta da concentração de poluentes. Em geral, níveis superiores a $100 \mu \mathrm{Scm}^{-1}$ em águas doces indicam ambientes impactados. A condutividade também fornece uma boa indicação das modificações na composição de uma amostra de água, especialmente na sua concentração mineral, mas não fornece nenhuma indicação das quantidades relativas dos vários componentes. À medida que mais sólidos dissolvidos são adicionados, a condutividade da água aumenta e altos valores podem indicar características corrosivas da água (CETESB, 2004b).

Assim como os parâmetros temperatura, salinidade, $\mathrm{pH}$ e oxigênio dissolvido, as medidas de condutividade foram possíveis através da utilização do aparelho de campo Water - Checker Horiba, modelo U-10, onde foram realizadas três leituras in situ em cada ponto de coleta.

\subsubsection{Sólidos Totais Suspensos na água (TSS)}

Os Sólidos Totais Suspensos (TSS) correspondem a soma de minerais, sais, metais, cátions e ânions suspensos na água, em unidades de massa por volume, na maioria das vezes em ppm ou $\mathrm{mgL}^{-1}$. Os sólidos suspensos em água são provenientes de material inorgânico como por exemplo as rochas, porém estes também podem ser fornecidos por fontes como matéria orgânica, plâncton, resíduos industriais, entre outras.

Para determinar os valores de TSS, as amostras de água foram homogeneizadas e, sob temperatura ambiente, tomou-se um volume de 100 $\mathrm{mL}$ e deixou-se evaporar em estufa a uma temperatura de $100^{\circ} \mathrm{C}$. Em seguida, pesou-se e calculou-se a massa dos sólidos presentes. 


\subsection{Caracterização das amostras de sedimento}

As amostras de sedimento foram caracterizadas de acordo com os parâmetros: umidade, $\mathrm{pH}$, matéria orgânica, capacidade de troca catiônica, carbono orgânico total e ácidos húmicos. Todas as determinações foram feitas em triplicatas.

\subsubsection{Teor de Umidade no sedimentos $(\mathrm{H})$}

O comportamento da água no solo é afetado pelo tamanho das partículas e o modo como elas estão arranjadas. O solo é um reservatório natural de água para as plantas e, sua textura, bem como o teor de matéria orgânica e a atividade biológica, afetam significativamente a retenção de água. Em geral, a porosidade total é maior e mais água é retida (ou absorvida) na parte mais superficial do solo, diminuindo a medida que se desce no perfil. A umidade dos sedimentos influencia fatores como $\mathrm{pH}$, salinidade, bem como a disponibilidade de nutrientes e/ou substâncias tóxicas para as plantas (JUHÁSZ, 2005).

A ação das marés varia ao longo das áreas de mangue, isto é, algumas zonas são inundadas diariamente enquanto outras serão atingidas apenas algumas vezes, em determinadas épocas. Isto se dá pelo fato do terreno possuir variações na sua topografia propiciando assim a existência de locais mais baixos (inundados mais vezes pelas marés) e outros mais elevados (alagados com menor freqüência) (SOARES, 1995).

Para determinar o teor de umidade, as amostras foram devidamente pesadas e submetidas à estufa a uma temperatura de $100-110^{\circ} \mathrm{C}$ por 24 horas. Após este período, deixou-se esfriar em ambiente livre de umidade (dessecador) até massa constante. A determinação do teor de umidade foi feita utilizando-se a seguinte equação: 


$$
\% \mathrm{H}_{\left(100-110^{\circ} \mathrm{C}\right)}=\left(\mathbf{P}_{1}-\mathbf{P}_{2}\right) / \mathbf{P}_{1} \times 100
$$

Onde:

$\% \mathrm{H}=$ teor de umidade

$\mathrm{P}_{1}=$ massa da amostra úmida

$\mathrm{P}_{2}=$ massa da amostra seca

\subsubsection{Potencial Hidrogeniônico do sedimento (pH)}

Conforme citado no item 4.3.3, o pH é um importante parâmetro que exerce influencia sobre o meio. Nos sedimentos, pode interferir no potencial de toxicidade dos metais, bem como a disponibilidade destes para os organismos, incluindo a forma e concentração em que eles se encontram.

A determinação do $\mathrm{pH}$ nas amostras de sedimentos foi feita através do método recomendado pelo Manual de Métodos de Análise de Solo da EMBRAPA. Primeiramente deixou-se secar o sedimento a uma temperatura de $40 \stackrel{\circ}{\circ}$ até massa constante (aproximadamente 30 horas). Em seguida, as amostras secas foram maceradas com o auxílio de um pistilo e almofariz, peneiradas em peneira de malha de $250 \mu \mathrm{m}$ de diâmetro e, a cada alíquota de $10 \mathrm{~g}$ foi adicionado $25 \mathrm{~mL}$ de uma solução de $\mathrm{CaCL}_{2}$ 0,01 M. Com agitação ocasional, após 30 minutos, determinou-se o pH da suspensão para cada caso.

\subsubsection{Teor de Matéria Orgânica no sedimento (OM)}

Em ambientes de solos tropicais e subtropicais, tais como os manguezais, a matéria orgânica cumpre um importante papel no fornecimento de nutrientes às plantas, através da formação de complexos. No entanto, como descrito no item 2.1, as substancias que constituem a matéria orgânica também se ligam a compostos tóxicos, o que acarreta muitas vezes em uma preocupação e não uma vantagem. Além destas, a matéria orgânica ainda influencia na infiltração e retenção de água, na aeração e na atividade microbiana (STEVENSON, 1994). Portanto, ao determinar metais e compostos 
organoclorados em sedimentos, é de grande interesse que se determine também a matéria orgânica.

As amostras de sedimento foram secas a uma temperatura de $40{ }^{\circ} \mathrm{C}$ até se obter massa constante, maceradas com o auxilio de um pistilo e almofariz e peneiradas em peneira de malha de $250 \mu \mathrm{m}$ de diâmetro. Após esta etapa, para cada amostra pesaram-se $2 \mathrm{~g}$ do sedimento seco que foram submetidos a uma temperatura de $550{ }^{\circ} \mathrm{C}$ para calcinação em mufla (marca EDGCON 1P1800) durante um período de 4 horas (ALLISON, 1965). E por fim as amostras foram resfriadas em ambiente livre de umidade (dessecador) e pesadas.

$\mathrm{Na}$ calcinação queima-se todo o material orgânico, restando apenas o inorgânico, desta maneira, por diferença de massa, determina-se o teor de matéria orgânica:

$$
\% O M=\left(P_{S}-P_{M}\right) / P_{S} \times 100
$$

Onde:

$\% \mathrm{OM}$ = teor de matéria orgânica.

$\mathrm{P}_{\mathrm{S}}=$ massa inicial.

$P_{M}=$ massa final (após a combustão).

E a determinação do teor de cinza ou o resíduo mineral total (KIEHL, 1985) pode ser feita através do seguinte cálculo:

$\%$ Cinza total $=\left(P_{M} / P_{S}\right) \times 100$ 


\subsubsection{Capacidade de Troca Catiônica do sedimento (CEC)}

A Capacidade de Troca Catiônica (CEC) é definida como a quantidade de cátions adsorvidos reversivelmente por unidade de massa de material seco e expressa a capacidade do solo ou sedimento de trocar cátions. A quantidade destes cátions é fornecida pelo número de cargas positivas (centimol ou milimol) e a massa de solo ou sedimento seca, geralmente $100 \mathrm{~g}$ ou $1 \mathrm{~kg}$. Os valores encontrados para minerais argilosos variam de 1 a $150 \mathrm{cmolkg}^{-1}$, enquanto a CEC para matéria orgânica pode atingir $400 \mathrm{cmolkg}^{-1}$, devido ao grande número de grupos oxigenados, particularmente carboxílicos $(-\mathrm{COOH})$, os quais podem ligar e trocar cátions. Para um solo fértil, são desejados valores elevados de CEC, uma vez que maiores quantidades de cátions podem ser armazenados e disponibilizados para as plantas (ROCHA; ROSA; CARDOSO, 2004).

A capacidade de troca catiônica efetiva pode ser determinada através da soma dos cátions metálicos totais trocáveis e a acidez trocável (JACKSON, 1967). Primeiramente, as amostras de sedimento foram secas a uma temperatura de $40 \stackrel{\circ}{ } \mathrm{C}$ até massa constante, maceradas com o auxilio de um pistilo e almofariz e peneiradas em peneira de malha de $250 \mu \mathrm{m}$ de diâmetro e, em seguida, foram realizadas duas etapas descritas abaixo.

A primeira etapa, a determinação dos cátions metálicos totais trocáveis, tem como finalidade o deslocamento dos cátions metálicos trocáveis dos componentes do solo através da troca com o próton do $\mathrm{CH}_{3} \mathrm{COOH}$. Desta maneira, determina-se a variação de $\mathrm{pH}$ ocorrida, sabendo-se a quantidade de íons $\mathrm{H}^{+}\left(\mathrm{H}_{3} \mathrm{O}^{+}\right)$deslocados. Os cátions trocáveis correspondem à soma dos íons $\mathrm{Ca}^{2+}, \mathrm{Mg}^{2+}, \mathrm{K}^{+}$e $\mathrm{Na}^{+}$.

Nesta etapa, pesaram-se 2,5 g de cada amostra de sedimento seco e adicionaram-se $25 \mathrm{~mL}$ de $\mathrm{CH}_{3} \mathrm{COOH}$ 1,0 M. A suspensão foi agitada durante uma hora em agitador automático (marca Tecnal TE-140) e posteriormente determinou-se o pH, bem como o pH da solução de $\mathrm{CH}_{3} \mathrm{COOH} 1,0 \mathrm{M}$. Para o cálculo dos cátions metálicos totais trocáveis das amostras foi usada a seguinte equação: 


\section{Cations Metálicos Totais Trocáveis $(\mathrm{cmol} / \mathrm{kg})=\left[\mathrm{pH}_{1}-\mathrm{pH}_{2}\right]_{\times} 22$}

Onde:

$\mathrm{pH}_{1}=\mathrm{pH}$ da suspensão.

$\mathrm{pH}_{2}=\mathrm{pH}$ do $\mathrm{CH}_{3} \mathrm{COOH} 1,0 \mathrm{M}$.

22 = constante logarítmica.

Na segunda etapa, a determinação da acidez trocável, adicionaram-se 5 $\mathrm{g}$ de cada amostra de sedimento seco em erlenmeyers $(125 \mathrm{~mL})$ e adicionouse a cada um $50 \mathrm{~mL}$ de uma solução de $\mathrm{KCl}$ 1,0 M. Agitou-se manualmente algumas vezes e deixou-se em repouso durante 30 minutos. Filtrou-se em papel de filtro adicionando-se duas porções de $10 \mathrm{~mL}$ de $\mathrm{KCl} 1,0 \mathrm{M}$. Posteriormente, adicionou-se ao filtrado 6 gotas de fenolftaleína a 0,1\% $\%$ / e titulou-se com uma solução de $\mathrm{NaOH} 0,01 \mathrm{M}$. Pela equação a seguir, determinou-se a acidez trocável:

$$
\text { Acidez trocável }_{(\mathrm{cmol} / \mathrm{kg})}=\left(\mathrm{V}_{\mathrm{x}} \mathrm{C}_{\mathrm{x}} 100\right) / \mathrm{m}
$$

Onde:

$\mathrm{V}=$ volume de $\mathrm{NaOH}$ gasto na titulação $(\mathrm{mL})$.

$\mathrm{C}=$ concentração de $\mathrm{NaOH}\left(\mathrm{molL}^{-1}\right)$.

$\mathrm{m}=$ massa da amostra $(\mathrm{g})$.

A soma dos valores encontrados para os cátions metálicos totais trocáveis e a acidez trocável resulta na determinação da capacidade de troca catiônica. 


\subsubsection{Teor de Carbono Orgânico Total no sedimento (TOC)}

O carbono orgânico é um importante parâmetro de estudo, uma vez que este, se acompanhado ao longo do tempo, é capaz de indicar as alterações da qualidade do solo em função do seu manejo. O carbono orgânico é proveniente basicamente da decomposição de vegetais e animais, com quantidades razoáveis de resíduos microbianos e da microfauna, mas este também pode derivar de fontes externas como despejos de esgotos e indústrias.

Para a determinação do carbono orgânico total, a princípio, as amostras de sedimento foram secas a uma temperatura de $40^{\circ} \mathrm{C}$ até massa constante, maceradas com o auxilio de um pistilo e almofariz e peneiradas em peneira de malha de $250 \mu \mathrm{m}$ de diâmetro e, em seguida, foram realizadas duas etapas: a determinação do carbono total e a do carbono inorgânico. Todas as medidas foram realizadas utilizando-se o equipamento TOC Analyser, modelo TOC-V, acoplado ao Solid Sample Module, modelo SSM-5000 A, com detector de combustão, ambos da marca Shimadzu.

$\mathrm{Na}$ primeira etapa, o carbono total é determinado pela oxidação do carbono orgânico e inorgânico quando se submete a amostra a uma temperatura de $900 \stackrel{\circ}{\circ}$. Para tal determinação, foram construídas curvas analíticas utilizando como padrão o biftalato de potássio $\left(\mathrm{HOCOC}{ }_{6} \mathrm{H}_{4} \mathrm{COOK}\right)$ e, em seguida, $100 \mathrm{mg}$ de cada amostra de sedimento seco foram submetidas para análise.

$\mathrm{Na}$ segunda etapa, onde é realizada a determinação do carbono inorgânico, utilizou-se carbonato de sódio anidro $\left(\mathrm{Na}_{2} \mathrm{CO}_{3}\right)$ acidificado com $\mathrm{H}_{3} \mathrm{PO}_{4}$ como padrão para as curvas analíticas e, aplicou-se uma temperatura de $200{ }^{\circ} \mathrm{C}$ para a oxidação e liberação de $\mathrm{CO}_{2}$. Na seqüência, submeteu-se, nas mesmas condições, $100 \mathrm{mg}$ de cada amostra de sedimento seco para análise. Assim, subtraindo-se os valores encontrados para carbono inorgânico dos valores encontrados para o carbono total, se obtiveram os valores de carbono orgânico nas amostras. 


\subsubsection{Teor de Ácidos Húmicos no sedimento (HA)}

A extração dos ácidos húmicos foi realizada segundo adaptação do procedimento recomendado pela Sociedade Internacional de Substâncias Húmicas (SWIFT, 1996).

Primeiramente, as amostras de sedimento foram secas em estufa a 40 ${ }^{\circ} \mathrm{C}$ até massa constante, trituradas com auxílio de pistilo e almofariz e peneiradas em peneira de malha de $250 \mu \mathrm{m}$. Para cada caso foram adicionados cerca de $50 \mathrm{~g}$ da amostra seca e peneirada em um béquer (de $1 \mathrm{~L}$ ) e acrescentou-se $500 \mathrm{~mL}$ de solução de $\mathrm{NaOH}$ 0,1 M. A mistura foi então agitada em um agitador automático (marca Quimis) por um período de 4 horas e submetida à centrifugação (marca Hitachi, modelo himacCR20B2) de 4000 rpm durante 15 minutos para se obter uma suspensão contendo os ácidos húmicos e fúlvicos, uma vez que estes são solúveis em meio alcalino.

Após se obter e separar a suspensão, adicionou-se solução de $\mathrm{HCl}$ 0,1 $\mathrm{M}$ até $\mathrm{pH}<2$ e reservou-se a mistura sob refrigeração por alguns minutos. Desta maneira, ao precipitar os ácidos húmicos, filtrou-se em papel de filtro e lavou-se o material retido no filtro com água milli-pore gelada para a retirada de impurezas. Após seco, pesou-se o filtrado e calculou-se o teor de ácidos húmicos nas amostras de sedimento.

\subsection{Preparo de amostras para determinação de metais}

As amostras in natura de sedimento e plantas foram todas secas em estufa a uma temperatura de $40^{\circ} \mathrm{C}$ até se obter massa constante, maceradas com o auxilio de um pistilo e almofariz e, no caso de sedimentos, peneiradas em peneira de malha de $250 \mu \mathrm{m}$ de diâmetro. Para a extração dos analitos de interesse (metais), as amostras foram submetidas à digestão ácida utilizandose um bloco digestor da marca Marconi, modelo MA850. Todas as extrações foram feitas em triplicatas. 


\subsubsection{Digestão Ácida de amostras de sedimento e raízes e folhas de mangues para a determinação de $\mathrm{Al}, \mathrm{Cd}, \mathrm{Pb}, \mathrm{Co}, \mathrm{Cu}, \mathrm{Cr}$, Fe, Mn, Ni e Zn}

O procedimento para a digestão ácida de amostras de sedimento e raízes e folhas de mangues segue uma adaptação do método 3050B da Environmental Protection Agency (EPA).

Em um tubo digestor, adicionou-se $0,5 \mathrm{~g}$ da amostra seca e somou-se um volume de $10 \mathrm{~mL}$ de $\mathrm{HNO}_{3}$ concentrado. Após 16 horas, elevou-se a temperatura do bloco digestor a $95^{\circ} \mathrm{C}\left( \pm 5^{\circ} \mathrm{C}\right)$ e permitiu-se o refluxo por 30 minutos. Resfriou-se e adicionou-se $5 \mathrm{~mL}$ de $\mathrm{HNO}_{3}$ concentrado e, novamente sob refluxo na mesma temperatura, evaporou-se a mistura a aproximadamente $5 \mathrm{~mL}$. Após resfriamento, adicionaram-se 3 alíquotas de $3 \mathrm{~mL}$ de $\mathrm{H}_{2} \mathrm{O}_{2} 30 \%$ cada. Em cada adição de peróxido, retornou-se o tubo digestor ao aquecimento permitindo a completa reação sem que houvesse efervescência em excesso. Deixou-se evaporar novamente até se obter aproximadamente $5 \mathrm{~mL}$ da mistura e, após resfriar, adicionou-se $10 \mathrm{~mL}$ de $\mathrm{HCl}$ concentrado e retornou-se ao refluxo por 20 minutos. Após a digestão, adicionou-se água milli-pore completando o volume para $50 \mathrm{~mL}$ com o auxilio de um balão volumétrico e filtrou-se a mistura em papel de filtro, estando esta pronta para análise por ICPAES.

\subsubsection{Digestão Ácida de amostras de água para a determinação de} $\mathrm{Al}, \mathrm{Cd}, \mathrm{Pb}, \mathrm{Co}, \mathrm{Cu}, \mathrm{Cr}, \mathrm{Fe}, \mathrm{Mn}$, Ni e $\mathrm{Zn}$

O procedimento para a digestão ácida de amostras de água segue uma adaptação do método 3005A da Environmental Protection Agency (EPA).

Adicionou-se ao tubo digestor $100 \mathrm{~mL}$ da amostra de água e somou-se um volume de $5 \mathrm{~mL}$ de $\mathrm{HNO}_{3}$ concentrado e $10 \mathrm{~mL}$ de $\mathrm{HCl}$ concentrado. Após 16 horas, elevou-se a temperatura do bloco digestor a $95^{\circ} \mathrm{C}\left( \pm 5^{\circ} \mathrm{C}\right)$ e permitiu-se o refluxo até o volume da mistura ser reduzido a aproximadamente 
$15 \mathrm{~mL}$. Resfriou-se a mistura, adicionou-se água milli-pore completando o volume para $50 \mathrm{~mL}$ com o auxilio de um balão volumétrico e, filtrou-se em papel de filtro, estando esta pronta para análise por ICP-AES.

\subsection{Determinação de metais por ICP-AES}

Após realizadas as etapas de extração, os metais pseudo-totais presentes nas amostras foram determinados através de Espectrometria de Emissão Atômica com Fonte de Plasma Indutivamente Acoplado (ICP-AES). Para tal, utilizou-se um equipamento da marca Perkin Elmer, modelo Optima 3000:

\subsubsection{Espectrometria de Emissão Atômica com Fonte de Plasma Indutivamente Acoplado (ICP-AES)}

Historicamente, a espectrometria de emissão atômica baseou-se na atomização e excitação por chama, arco elétrico e centelha elétrica, todos esses métodos continuam tendo aplicações importantes na análise de elementos metálicos. Atualmente, entretanto, fontes de plasma têm se tornado o método mais importante e largamente utilizado para a espectroscopia de emissão atômica (SKOOG, 2002).

Por definição, plasma é uma mistura gasosa condutora de eletricidade que contém uma concentração significativa de cátions e elétrons. Em um plasma de argônio, freqüentemente, empregado em análises por emissão, os íons argônio e elétrons são as principais espécies condutoras, embora os cátions da amostra também estejam presentes em menor quantidade. Os íons argônio, uma vez formados em um plasma, são capazes de absorver energia suficiente para manter a temperatura em um nível no qual ionizações adicionais sustentam o plasma indefinidamente; temperaturas maiores que $10.000 \mathrm{~K}$ são encontradas. Três tipos de plasma de alta temperatura são encontrados: 
plasma indutivamente acoplado (ICP), plasma corrente contínua (DCP) e plasma induzido por microondas (MIP) (SKOOG, 2002).

A espectrometria de emissão atômica com plasma indutivamente acoplado (ICP-AES) é uma técnica que usa plasma de argônio como fonte de excitação. O plasma de argônio é formado pela ação do campo magnético da bobina, sobre o argônio, na tocha. A tocha consiste de tubos concêntricos com fluxo de argônio independentes para cada um. O topo da tocha é centrado de uma bobina de radiofreqüência $(R F)$, que é a fonte de energia do sistema. Depois da ignição, o plasma é propagado indutivamente com o campo gerado na bobina de radiofreqüência (BOSTELMANN, 2006).

A Figura 17 representa o esquema da tocha (quartzo) que é a configuração que sustenta o plasma, circundada por uma bobina de indução (resfriada a água ou ar) através da qual uma energia de 2 a $3 \mathrm{~kW}$ é fornecida, sendo o gerador de freqüência de 27 ou 40 MHz (LEMES, 2001). A amostra é introduzida dentro de uma câmara de mistura, onde é direcionada até o tubo central da tocha do ICP-AES (BEATY; KERBER, 1993; BACCAN, 1994, BOSTELMANN, 2006).

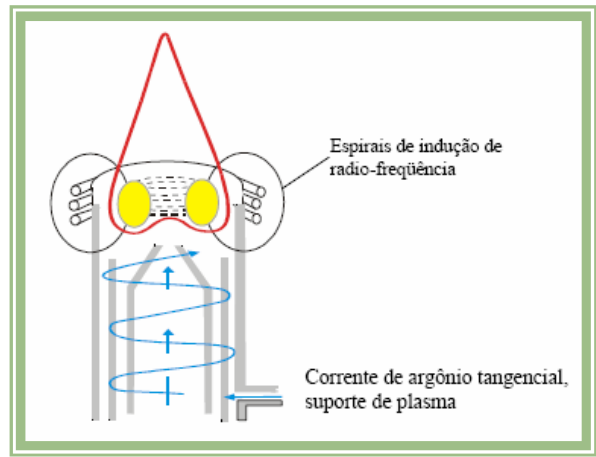

Figura 17: Diagrama esquemático de uma fonte de plasma de argônio (extraído de LEMES, 2001).

A amostra em solução, por meio da nebulização, transforma-se em aerossol o qual após a dessolvatação passa a partícula seca que, por volatilização-dissociação, vai para a forma de vapores atômicos iônicos, os quais são excitados na forma de átomos-íons. O mecanismo de excitação é 
colisional. A tendência dos elétrons excitados é de voltarem ao estado fundamental e assim devolvem a energia de emissão, onde os comprimentos de onda são característicos de cada elemento (Figura 18) e a intensidade da linha do espectro de emissão é proporcional à concentração do elemento em determinação (OLIVEIRA, 1998; LEMES, 2001).

\section{Processo de Emissão Atômica}

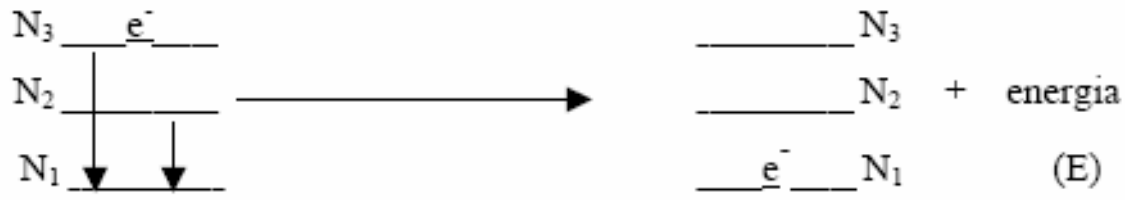

Estado Excitado

Estado Fundamental

Figura 18: Representação da emissão atômica (extraído de LEMES, 2001)

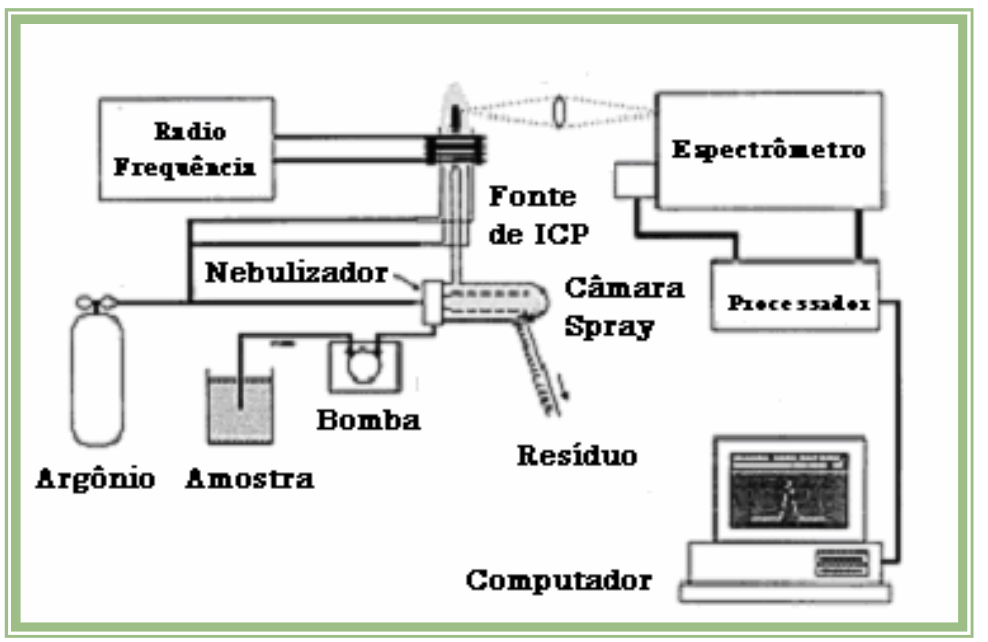

Figura 19: Esquema dos principais componentes de um ICP-AES (adaptado de BEATY; KERBER, 1993).

A técnica de ICP-AES aplica-se a um grande número de metais, principalmente para os chamados refratários (que formam óxidos estáveis e não se decompõem facilmente com a temperatura da chama). É uma técnica amplamente utilizada em análise ambiental por suas características (YABE, 1995; CHARLES; FREDEEN, 1997; GATTI, 1997; DANTAS, 1999; SANTOS, 1999; LEME, 2001): 
- É uma técnica multielementar rápida que permite a determinação simultânea de seus constituintes maiores, menores e traço;

- Embora a sensibilidade da técnica para muitos dos elementos comumente determinados não seja muito baixa, por exemplo, $\mathrm{Cu}, \mathrm{Cd}, \mathrm{Ni}, \mathrm{Pb}, \mathrm{Zn}$, não existe grande diferença quando comparada a técnica Espectrométrica de Absorção Atômica (AAS), porém ela é muito sensível para elementos metálicos refratários (por exemplo $\mathrm{V}, \mathrm{Be}$ ) bem como para alguns metálicos como B e P;

- A baixa vulnerabilidade do ICP-AES para os interferentes interelementares, faz com que a calibração para uma variedade de materiais ambientais seja muito mais fácil do que para a técnica de Espectrometria de Absorção Atômica.

\subsubsection{Condições espectrométricas}

O equipamento utilizado nas análises de metais disponibiliza recursos em seu programa que permitem a escolha criteriosa das linhas de emissão a serem utilizadas para cada elemento. A determinação dos metais foi possível através do método do gráfico analítico, utilizando-se soluções padrões multielementares em concentrações distintas para cada metal e acidificadas com $\mathrm{HNO}_{3}$ (2\%), a fim de se aproximar das condições reais tal qual se aplicou às amostras (tabela 6). As condições de operação seguem abaixo:

Fluxo dos gases:

- Gás refrigerante $\mathrm{Ar}: 15 \mathrm{Lmin}^{-1}$

- Gás auxiliar Ar: $0.5 \mathrm{Lmin}^{-1}$

- Gás nebulizador Ar: $0.8 \mathrm{Lmin}^{-1}$

Potência do plasma: $1300 \mathrm{~W}$

Fluxo de amostra: $1 \mathrm{mLmin}^{-1}$ 
Tabela 6: Condições espectrométricas de análise.

\begin{tabular}{ccc}
\hline Metal & $\begin{array}{c}\text { Faixa de Concentração } \\
\left(\mathbf{m g L}^{-1}\right)\end{array}$ & $\begin{array}{c}\lambda^{1} \\
(\mathbf{n m})\end{array}$ \\
\hline $\mathbf{A l}$ & 0,$0 ; 5,0 ; 20 ; 35 ; 50$ & 308,215 \\
\hline $\mathbf{C d}$ & 0,$0 ; 0,1 ; 0,3 ; 0,5 ; 0,8$ & 214,438 \\
\hline $\mathbf{P b}$ & 0,$0 ; 1,0 ; 3,0 ; 5,0 ; 8,0$ & 220,353 \\
\hline $\mathbf{C o}$ & 0,$0 ; 0,5 ; 1,5 ; 3,0 ; 4,0$ & 228,616 \\
\hline $\mathbf{C u}$ & 0,$0 ; 1,0 ; 3,0 ; 5,0 ; 8,0$ & 324,754 \\
\hline $\mathbf{C r}$ & 0,$0 ; 0,5 ; 1,5 ; 3,0 ; 4,0$ & 205,560 \\
\hline $\mathbf{F e}$ & 0,$0 ; 5,0 ; 20 ; 35 ; 50$ & 238,204 \\
\hline $\mathbf{M n}$ & 0,$0 ; 0,5 ; 1,0 ; 1,5 ; 2,0$ & 257,610 \\
\hline $\mathbf{N i}$ & 0,$0 ; 0,5 ; 1,5 ; 3,0 ; 4,0$ & 232,003 \\
\hline $\mathbf{Z n}$ & 0,$0 ; 0,1 ; 0,3 ; 0,5 ; 0,6$ & 213,856 \\
\hline
\end{tabular}

${ }^{1} \lambda$ é o comprimento de onda em que se realizou a determinação.

\subsubsection{Limite de Detecção e Limite de Quantificação}

O limite de detecção (LOD) expressa a menor quantidade de um analito que pode ser detectada por um determinado método analítico, no entanto, não quantificada como um valor exato. Segundo Thompson (1987), o LOD do instrumento é definido como a concentração do analito que fornece uma resposta igual a três vezes o valor do desvio padrão do branco, o qual foi obtido através de cinco leituras simultâneas de água milli-pore acidificada com $\mathrm{HNO}_{3} 2 \%$. No entanto, alguns valores de limites de detecção são muito "otimistas", assim, com uma maior segurança, foram utilizados valores de limites de quantificação (LOQ), que correspondem à menor quantidade de um analito que pode ser quantificada com exatidão e fidelidade determinada, os quais fornecem uma resposta igual a seis vezes o valor do desvio padrão da leitura do branco.

\subsubsection{Quantificação dos metais pseudo-totais}

Os gráficos analíticos são representados pela equação da reta ou regressão linear $(y=a+b x)$, onde a concentração de cada analito é dada pela equação (SANTOS, 1999): 


$$
\text { Ir }=a_{0}+a_{1 \times} C
$$

Onde:

Ir = intensidade relativa da emissão do analito

$\mathrm{C}=$ concentração do analito $\left(\mathrm{mgL}^{-1}\right)$

$\mathrm{a}_{\mathrm{o}}=$ coeficiente linear da regressão

$\mathrm{a}_{1}=$ coeficiente angular da regressão

\subsection{Preparo de amostras para a determinação de compostos organoclorados}

A maioria das amostras reais requer várias etapas antes da medida da concentração do analito de interesse em um instrumento. Neste trabalho, para determinar pesticidas organoclorados em amostras de sedimento e raízes e folhas de mangues através de cromatografia gasosa com detector de captura de elétrons, os analitos foram primeiramente extraídos das amostras através da utilização do método Soxhlet seguido do Clean-up (extração em fase sólida) e Fluxo de Nitrogênio para pré concentração da amostra.

\subsubsection{Extração Soxhlet}

O método de extração utilizado para os compostos organoclorados foi o método clássico de Soxhlet (figura 20). Este método consiste no tratamento sucessivo e intermitente da amostra imersa em um solvente puro (éter de petróleo, éter dietílico ou n-hexano), graças à sifonagem e subseqüente condensação do solvente aquecido dentro do balão que está na base do aparelho.

As mais notáveis vantagens que o método de Soxhlet apresenta são: a amostra está sempre em contato com o solvente, havendo sua constante renovação; a temperatura do sistema mantém-se relativamente alta, visto que o calor aplicado para o processo de evaporação é constante; é uma metodologia 
muito simples que não requer treinamento especializado e que possibilita a extração de uma quantidade maior de óleo em relação a outros métodos, sem a necessidade de filtração da miscela após o término da extração, pois a amostra esteve envolta no cartucho durante todo o procedimento. (BRUM, 2004)

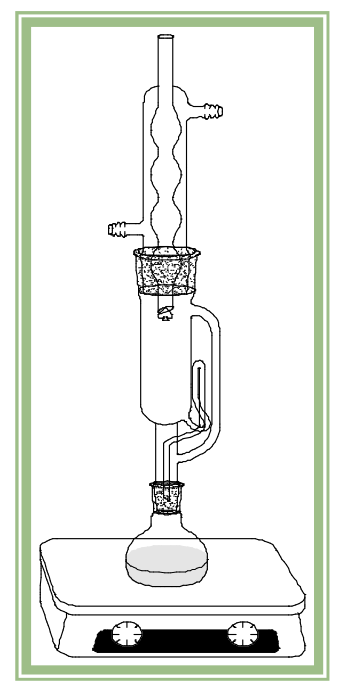

Figura 20: Extrator Soxhlet.

Apesar dos inconvenientes que o método de Soxhlet apresenta, como 0 longo tempo requerido de extração e o grande volume de solvente utilizado, é recomendado pelas Normas Analíticas do Instituto Adolfo Lutz..

Conforme procedimento adaptado do método 3540 da Environmental Protection Agency (EPA), utilizou-se $150 \mathrm{~mL}$ de solvente hexano como extrator a cada alíquota de $10 \mathrm{~g}$ de amostra in natura, tanto para sedimento como para raízes e folhas de mangues. Cada extração durou 12 horas e, após este período, a amostra foi submetida a um roto evaporador (marca Fisatom, modelo 802D) a $50 \mathrm{rpm}$ em uma temperatura de $40 \stackrel{\circ}{\mathrm{C}}$ até se obter aproximadamente $5 \mathrm{~mL}$ de extrato, o qual adicionou-se cerca de $1 \mathrm{~g}$ de sulfato de sódio anidro $\left(\mathrm{Na}_{2} \mathrm{SO}_{4}\right)$, previamente calcinado a $600{ }^{\circ} \mathrm{C}$ por duas horas, para etapa posterior. 


\subsubsection{Clean-up - Extração em Fase Sólida (SPE): isolamento da matriz}

A etapa de clean-up é fundamental para se eliminar compostos provenientes da matriz e presentes no extrato os quais podem interferir com o método analítico a ser utilizado.

A técnica empregada no clean-up das amostras foi a extração em fase sólida (SPE) (figura 21). Esta é uma técnica de separação líquido-sólido baseada nos mecanismo de separação da cromatografia líquida clássica. Do ponto de vista prático a SPE comporta-se como uma cromatografia líquida, empregando-se em uma pequena coluna aberta, usualmente denominada cartucho de extração, a qual contém a fase sólida. A solução contendo o analito de interesse é colocada no topo superior do cartucho e aspirada com um pequeno vácuo ou pressionada levemente com uma seringa de forma a penetrar no cartucho. Após a fase líquida contendo os compostos de interesse ser drenada, o analito que ainda se encontra retido pode ser eluído com um pequeno volume de solvente (LANÇAS, 2004a).

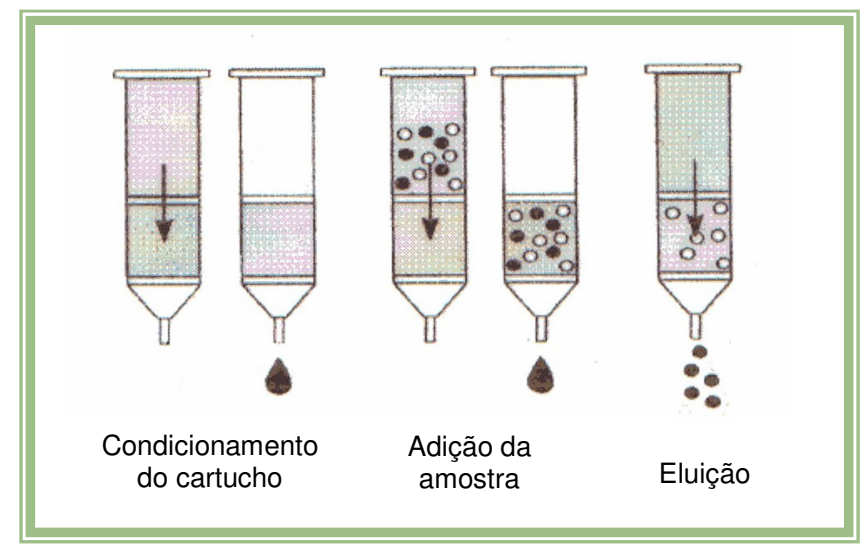

Figura 21: Principais etapas em SPE, visando o isolamento de um analito.

No presente trabalho, se utilizou como fase estácionária (sólida) $2 \mathrm{~cm}$ (em um cartucho de $5 \mathrm{~mL}$ ) de Florisil $\left(\mathrm{Mg}_{2} \mathrm{SiO}_{3}\right)$, o qual foi previamente calcinado em $650^{\circ} \mathrm{C}$ por 12 horas, armazenado em dessecador e, a cada aplicação, ativado em estufa a $130 \stackrel{\circ}{\circ}$ por 5 horas. Realizando-se então o 
clean-up da amostra obtida na etapa anterior (item 3.4.1), com $15 \mathrm{~mL}$ de solvente hexano como eluente. Após esta etapa, o extrato resultante foi préconcentrado a um volume de $1 \mathrm{~mL}$ para análise, utilizando-se para tal um fluxo de $\mathrm{N}_{2}$ até a secura do extrato e a reconstituição em solvente hexano.

\subsection{Determinação de compostos organoclorados por GC-ECD}

Após realizadas as etapas de extração, os compostos organoclorados presentes nas amostras de sedimento e raízes e folhas de mangues foram determinados através de Cromatografia Gasosa, utilizando um cromatógrafo a gás da marca Hewlett Packard, modelo HP-5890 com injetor split, acoplado a um detector de captura de elétrons.

\subsubsection{Cromatografia Gasosa (GC)}

A cromatografia é um método físico-químico de separação dos componentes de uma mistura que constitui de duas fases em contato íntimo: uma que permanece estacionária e outra que se move através desta. A cromatografia gasosa (GC) é usada para substâncias que apresentam a fase móvel líquida ou gasosa e a fase estacionária sólida ou líquida.

A GC tem um ótimo poder de resolução, tornando possível muitas vezes, a análise de dezenas de substâncias em uma única amostra. Dependendo do tipo de amostra, o detector empregado consegue detectar cerca de $10^{-12} \mathrm{~g}$. É importante salientar ainda que a GC é excelente como técnica quantitativa, sendo possível a obtenção de dados quantitativos em concentrações que variam de picogramas a miligramas (CIOLA, 1985; COLLINS; BRAGA; BONATO, 1990).

A amostra, através de um sistema de injeção, é introduzida em uma coluna contendo a fase estacionária e, com o uso de temperatura adequada no local de injeção e na coluna, a amostra é vaporizada e arrastada por uma 
corrente de gás que passa continuamente pela coluna (figura 22). De acordo com as propriedades das substâncias contidas na amostra e as da fase estacionária, estas substâncias são retidas por tempos determinados e chegam à saída da coluna em tempos diferentes. O uso de um detector adequado na saída da coluna torna possível a detecção e quantificação destas substâncias (COLLINS; BRAGA; BONATO, 1990).

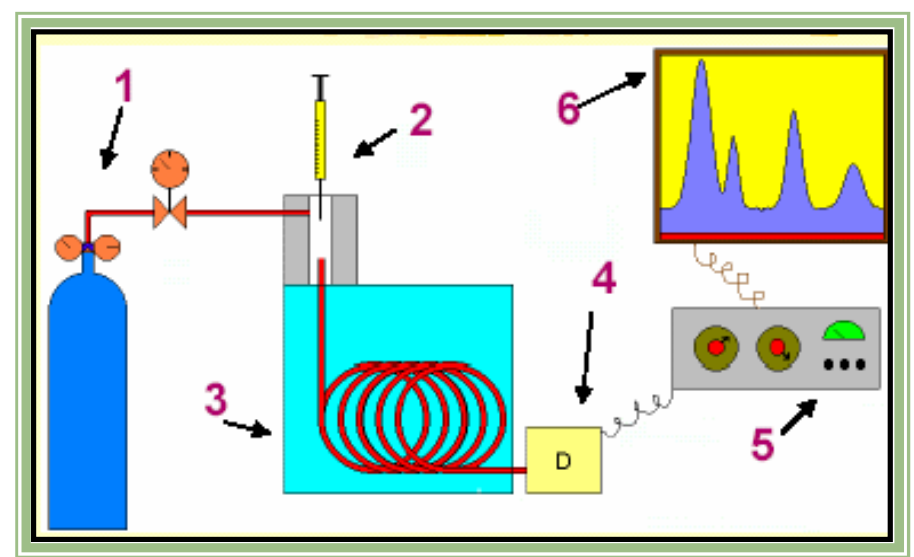

Figura 22: Esquema de Cromatografia a Gás: (1) Reservatório de Gás e Controles de Vazão/Pressão; (2) Injetor (Vaporizador) de Amostra;(3) Coluna Cromatográfica e Forno da Coluna; (4) Detector; (5) Eletrônica de Tratamento (Amplificação) de Sinal; (6) Registro de Sinal (Registrador ou Computador).

A GC pode ser empregada em análises de compostos voláteis e estáveis termicamente, caso contrário ela apresenta alguns inconvenientes, como a necessidade de formar derivados com estas características, o que nem sempre é viável. A análise cromatográfica isoladamente é rápida, entretanto, na maioria das vezes, há necessidade de etapas de preparação da amostra para não ocorrer interferência durante a análise e contaminação da coluna cromatográfica, sendo estas etapas muitas vezes longas e complexas.

Por serem compostos voláteis e por conterem grupos halogenados $\left(\mathrm{Cl}^{-}\right)$, os pesticidas organoclorados geralmente são analisados por cromatografia gasosa com detector de captura de elétrons (GC-ECD). 


\subsubsection{Detector de Captura de Elétrons (ECD)}

Em um sistema de cromatografia em fase gasosa o detector é, sem dúvida, o principal responsável pela quantidade mínima de substância a ser detectada, enquanto cabe, em princípio, à coluna a responsabilidade de estabelecer a quantidade máxima. Dentre as diversas características desejáveis para um bom detector, as principais são: seletividade elevada, baixo nível de ruído, resposta, ampla faixa de linearidade e quantidade mínima detectada. Devido a essas características desejáveis, o detector utilizado na análise foi o Detector por Captura de Elétrons (ECD).

O detector por captura eletrônica (figura 23) tem seu funcionamento baseado na captura de elétrons pela amostra, elétrons estes gerados pela ionização do gás de arraste por uma fonte radioativa (LANÇAS, 1993).

A medida em que o gás de arraste (geralmente nitrogênio) flui através do detector, uma lâmina contendo fonte radioativa $\left({ }^{3} \mathrm{H}\right.$ ou $\left.{ }^{63} \mathrm{Ni}\right)$ ioniza as moléculas do gás e forma elétrons lentos. Os elétrons são atraídos para o anodo, o qual se encontra com uma ddp de +90 volts em relação ao catodo. Como conseqüência, este fluxo de elétrons irá gerar uma corrente constante também conhecida como corrente padrão (cerca de $10^{-8} \mathrm{~A}$ ). Uma molécula contendo grupos que apresentam afinidade por elétrons sendo eluida da coluna junto com o gás de arraste, ao passar pelo detector irá capturar os elétrons livres produzidos na ionização do gás de arraste. Como conseqüência, isto irá diminuir a corrente e ocasionar o aparecimento de um pico negativo (na prática observa-se picos positivos regulares, uma vez que a polaridade do registrador é invertida) (LANÇAS, 1993).

Os elétrons coletados após a ionização do gás de arraste pela fonte radioativa, ao serem capturados pela amostra irão gerar um sinal elétrico. Este sinal é enviado a um eletrômetro que o amplifica e registra o cromatograma. 


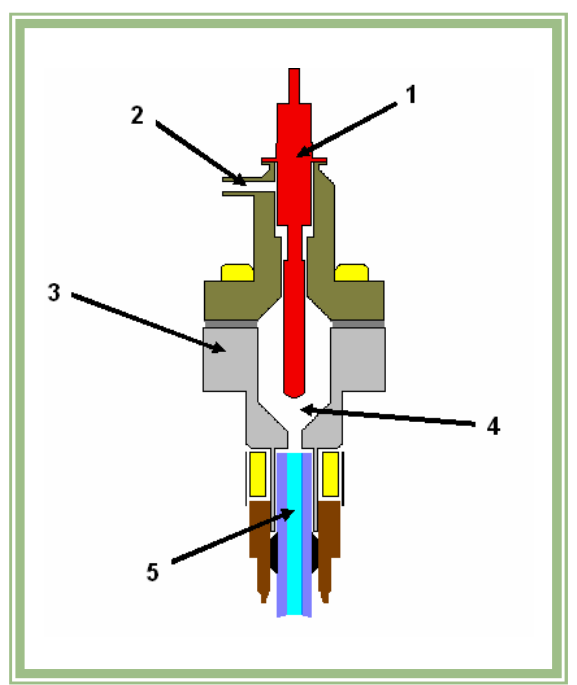

Figura 23: Esquema do Detector de Captura de Elétrons (ECD): (1) Anodo - fonte radioativa $\beta$; (2) Saída de gases; (3) Catodo; (4) Cavidade; (5) Coluna Cromatográfica.

O ECD é um detector seletivo, sensível e não destrutivo. Tem sido empregado no estudo de haletos de alquila, nitrilos, nitratos, carbonilas conjugadas e compostos organometálicos. É bastante insensível à presença de hidrocarbonetos, álcoois, cetonas e várias outras classes de compostos orgânicos, daí ser usado com sucesso no estudo de compostos presentes ao nível de traços, tais como resíduos agrotóxicos em alimentos. A tabela 7 ilustra a resposta relativa do ECD para várias classes de compostos (LANÇAS, 1993).

Tabela 7: Resposta relativa do detector ECD à algumas classes de compostos.

\begin{tabular}{lc}
\hline Classe & Resposta relativa \\
\hline Hidrocarbonetos & 1 \\
\hline Ésteres e éteres & 10 \\
\hline Aminas, cetonas e álcoois & $10^{2}$ \\
\hline Monocloro e monofluor & $10^{3}$ \\
\hline Dicloro e difluor & $10^{3}$ \\
\hline Monobromo & $10^{3}$ \\
\hline Tricloro & $10^{4}$ \\
\hline Anidridos & $10^{4}$ \\
\hline Monoiodo e dibromo & $10^{5}$ \\
\hline Policloro e polifluor & $10^{5}$ \\
\hline Diiodo e tribromo & $10^{6}$ \\
\hline
\end{tabular}




\subsubsection{Condições Cromatográficas}

A coluna utilizada para a separação foi uma coluna capilar de sílica fundida (SBP-5) de $30 \mathrm{~m}$ de comprimento e diâmetro interno de 0,25 mm com a parede interna recoberta por um filme de 0,25 $\mu \mathrm{m}$. Para a determinação dos analitos injetou-se $1 \mu \mathrm{L}$ de amostra, sob as seguintes condições:

Fluxo dos gases:

- Gás de arraste $\mathrm{H}_{2}: 1 \mathrm{~mL} / \mathrm{min}$

- Gás auxiliar $\mathrm{N}_{2}: 1 \mathrm{~mL} / \mathrm{min}$

Temperatura:

- Injetor: $270 \stackrel{\circ}{\mathrm{C}}$

- Detector: $320^{\circ} \mathrm{C}$

- Coluna: $170 \stackrel{\circ}{\mathrm{C}}-1 \mathrm{~min}$

$2{ }^{\circ} \mathrm{C} / \mathrm{min}$ até $176{ }^{\circ} \mathrm{C}-11 \mathrm{~min}$

$2{ }^{\circ} \mathrm{C} / \mathrm{min}$ até $196{ }^{\circ} \mathrm{C}-1 \mathrm{~min}$

$6{ }^{\circ} \mathrm{C} / \mathrm{min}$ até $250^{\circ} \mathrm{C}-10 \mathrm{~min}$

- Injetor split 1:13

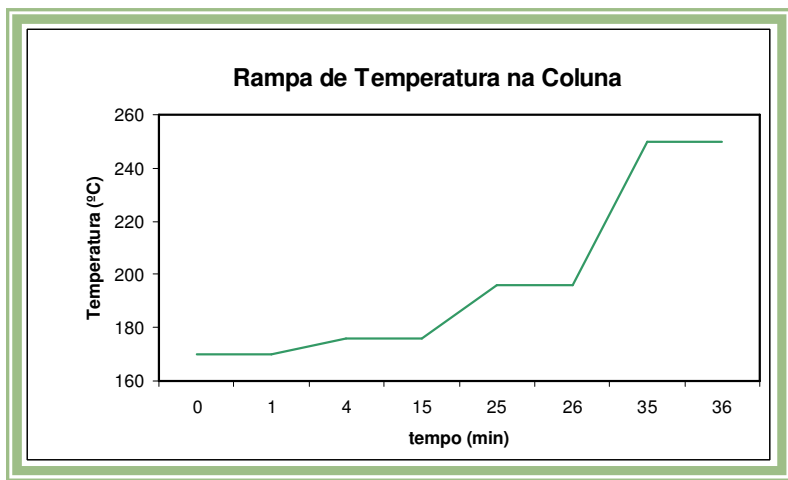

Figura 24: Rampa de Temperatura para a separação dos compostos organoclorados.

\subsubsection{Limite de Detecção e Limite de Quantificação}

Conforme definição descrita no item 4.6.3, o limite de detecção (LOD) expressa a menor quantidade de um analito que pode ser detectada, enquanto que o limite de quantificação (LOQ) expressa a menor quantidade de um 
analito que pode ser quantificada com exatidão e fidelidade. Nesta etapa, os LOD e LOQ foram determinados com base na definição da International Union of Pure and Applied Chemistry (IUPAC), através dos gráficos de calibração de cada composto (LONG; WINWFORDER, 1983; KRULL; SWARTZ, 1998), segundo as equações 9 e 10:

$$
\begin{aligned}
& L O D=3,3 \times \mathrm{S} / \mathrm{a} \\
& L O Q=10 \times \mathrm{S} / \mathrm{a}
\end{aligned}
$$

Onde:

$\mathrm{S}=$ desvio padrão da menor concentração obtida

$a=$ coeficiente angular da reta $(y=a x+b)$

\subsubsection{Avaliação do Método}

Para a análise quantitativa, o método pode ser avaliado através da interpretação estatística dos resultados obtidos nos cromatogramas, onde alguns parâmetros como Recuperação, Exatidão, Precisão e Linearidade foram determinados, podendo demonstrar diferentes formas de erros introduzidos nas análises.

- Recuperação

A recuperação é uma medida de eficiência do processo de isolamento do analito de interesse da matriz na qual se encontra presente (Lanças, 2004b), e pode ser determinada pela relação:

$$
\text { Recuperação(\%) = (valor obtido/valor adicionado) } \times 100
$$


Desta maneira, adicionou-se $1 \mathrm{~mL}$ da solução padrão dos 19 compostos organoclorados com concentração conhecida em $10 \mathrm{~g}$ de solo, previamente calcinado, utilizado como matriz e, em seguida, submeteu-se aos mesmos procedimentos de extração e determinação em GC-ECD tal qual as amostras. Esse procedimento foi realizado para três níveis de concentração (1, 10 e 50 ppb) e em quintuplicata cada um. Assim, foi possível determinar a porcentagem de recuperação do método, bem como a exatidão e precisão.

- Exatidão

A exatidão expressa a concordância entre o valor encontrado e o valor aceito como verdadeiro e pode ser determinada por intermédio do uso de uma amostra certificada com concentração do analito conhecida. Após a extração do analito e injeção no cromatógrafo, a resposta obtida é comparada com aquela dada pela análise do padrão de referência dissolvido em um solvente puro (Lanças, 2004b).

$$
\text { Exatidão }=\left\{1-\left[\left(V_{r}-V_{d}\right) / V_{r}\right]\right\} \times 100
$$

Onde:

$\mathrm{V}_{\mathrm{r}}=$ valor real de concentração

$\mathrm{V}_{\mathrm{d}}=$ valor de concentração determinado pelo método aplicado

- Precisão

A precisão é a expressão da concordância entre vários resultados analíticos obtidos para uma mesma amostra, ou seja, a capacidade de repetir (em condições experimentais muito próximas) um resultado analítico, e esta pode ser determinada em condições de repetibilidade ou reprodutibilidade. A precisão tem sido medida por meio do desvio padrão ou do coeficiente de variação (Lanças, 2004b). 


$$
\begin{gathered}
S=\left\{\left[\Sigma(x-\bar{x})^{2}\right] /(n-1)\right\}^{1 / 2} \\
C V=(S / \bar{x}) \times 100
\end{gathered}
$$

Onde:

$\mathrm{S}=$ desvio padrão

$\mathrm{X}=$ valor medido $\mathrm{e} \overline{\mathrm{x}}=$ média dos valores medidos

$\mathrm{n}=$ número de medidas

$\mathrm{CV}=$ coeficiente de variação ou desvio padrão relativo

- Linearidade

A linearidade é a resposta obtida em função da concentração do analito, a qual deve ser estudada em um intervalo de concentração apropriado. $\mathrm{Na}$ prática, a linearidade é determinada através de gráficos de calibração que relacionam a resposta do equipamento de análise em função de várias concentrações do analito de estudo. O número mínimo de pontos geralmente aceito nos gráficos de calibração para a obtenção da equação da função $(y=a+$ $b x)$ varia entre 5 e 6 e o coeficiente de correlação $\left(R^{2}\right)$ deve apresentar valor acima de 0,99 para ser satisfatório (ANVISA, 2003). No presente trabalho, foram construídos gráficos de calibração utilizando um padrão de 19 compostos organoclorados nas concentrações 0,$0 ; 0,5 ; 1 ; 2 ; 10$ e 50 ppb.

\subsubsection{Quantificação dos compostos organoclorados}

A quantificação do analito durante os estudos de recuperação é, geralmente, feita por métodos do padrão externo ou do padrão interno. $O$ método do padrão externo é mais simples, rápido e barato, apesar de estar muitas vezes sujeito a erros (Lanças, 2004b). No presente trabalho adotou-se a padronização externa, na qual se utilizou a linearidade dos compostos através dos gráficos de calibração (relação: concentração/área - constante) para os cálculos das concentrações dos analitos nas amostras reais. 


\subsection{Destino dos Resíduos de Laboratório}

No presente trabalho, para a realização de todos os procedimentos, buscou-se seguir as normas das Boas Práticas de Laboratório (GLP), que consiste na utilização do sistema de qualidade à organização e às condições sob as quais os estudos em laboratório e no campo são planejados, realizados, monitorados, registrados, relatados e arquivados (Handbook Good Laboratory Practice). Portanto, os resíduos gerados no projeto foram rotulados conforme as normas e encaminhados ao Laboratório de Resíduos Químicos do Instituto de Química de São Carlos - USP para posterior tratamento. 


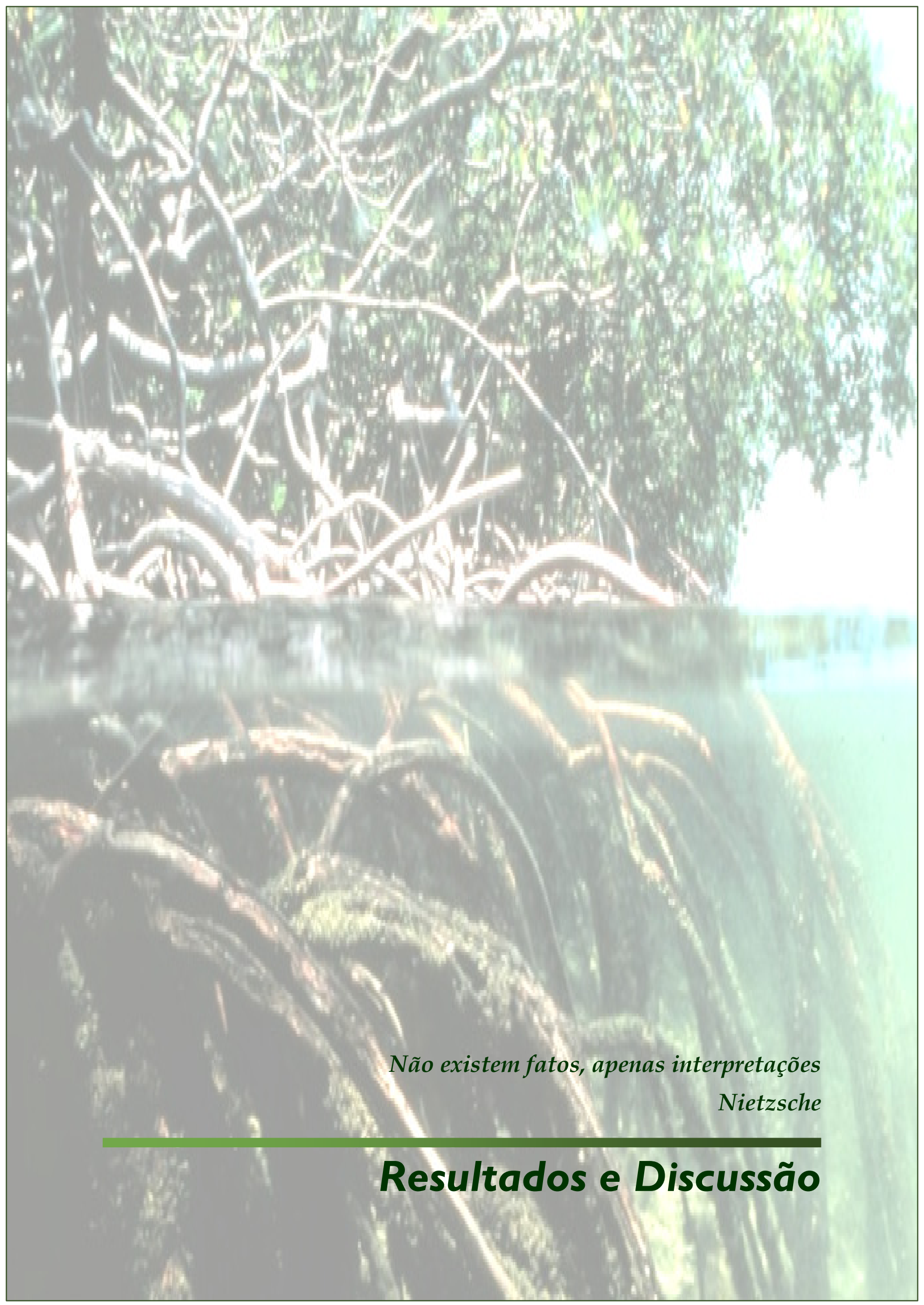




\section{RESULTADOS E DISCUSSÃO}

A princípio, é interessante revelar a aparência nas embocaduras dos manguezais citados. Independente dos resultados analíticos obtidos, o que se pode observar tanto na região da Baixada Santista como em Cananéia, é que estes são ecossistemas ricos em uma variedade de espécies de aves, crustáceos, moluscos, peixes e insetos. A atividade pesqueira é intensa, seja ela esportiva ou profissional. Grandes bancos de lodo podem ser notados durante a maré baixa, principalmente na região da Baixada Santista.

No complexo estuarino da Baixada Santista, ainda foi possível verificar que alguns locais apresentaram, em contraste com a imensa beleza natural, grande quantidade de resíduos sólidos, tais como embalagens de plásticos, sofás boiando, pneus entre outros. Em um dos trajetos durante a realização das coletas, nosso barco foi surpreendido por um pneu que se prendeu ao motor, quase prejudicando nosso trabalho. Além disso, as palafitas também são bem evidentes, onde nos causou a impressão da falta de controle na descarga de esgotos.

Já no complexo estuarino de Cananéia, pudemos ser acompanhados por golfinhos durante parte do trajeto na realização das coletas, no entanto, nas proximidades de pontes e balsas também foi possível observar a presença de resíduos despejados inadequadamente, embora em menor quantidade quando comparado com a região da Baixada Santista.

\subsection{Caracterização das amostras de água}

De acordo com a Resolução nํ 357 de 17/03/2005 do CONAMA, corpos d'água que apresentam salinidade entre 0,5 e 30\% são denominados como águas salobras. Os resultados obtidos para salinidade condizem com essa definição, com exceção do ponto 4 da Baixada Santista e do ponto 4 de Cananéia. No entanto, neste trabalho foi considerada apenas a definição salobra, uma vez que os valores de salinidade variam muito de acordo com a 
periodicidade de inundações e marés. Observando os valores obtidos para a salinidade na tabela 8 e comparando estes com a localização dos pontos de coleta mostrados nas figuras 15 e 16, verificou-se que quanto mais próximo do mar, maiores são esses valores, o que era de se esperar.

Tabela 8: Caracterização das amostras de água'.

\begin{tabular}{|c|c|c|c|c|c|c|}
\hline \multirow[t]{2}{*}{ Amostra } & \multicolumn{6}{|c|}{$\begin{array}{l}\text { Parâmetros estudados nas amostras de água coletadas em duas áreas de } \\
\text { manguezais do litoral do estado de São Paulo, a Baixada Santista (W1 a W5) } \\
\text { nos dias } 08 \text { e 09/09/2005 e Cananéia (CW1 a CW5) no dia 04/11/2005 }\end{array}$} \\
\hline & $\begin{array}{c}T \\
\left({ }^{\circ} \mathrm{C}\right)\end{array}$ & $\begin{array}{c}\mathbf{S} \\
(\%)\end{array}$ & $\mathrm{pH}$ & $\begin{array}{c}\mathrm{DO} \\
\left(\mathrm{mgL}^{-1}\right)\end{array}$ & $\begin{array}{c}E C \\
\left(\mathrm{mScm}^{-1}\right)\end{array}$ & $\begin{array}{l}\text { TDS } \\
\left(\mathrm{gL}^{-1}\right)\end{array}$ \\
\hline W1 & $23,33 \pm 0,12$ & $2,41 \pm 0,00$ & $7,07 \pm 0,02$ & $4,68 \pm 0,31$ & $37,80 \pm 0,00$ & $35,87 \pm 0,15$ \\
\hline W2 & $23,70 \pm 0,00$ & $2,19 \pm 0,00$ & $7,37 \pm 0,14$ & $6,10 \pm 0,39$ & $34,60 \pm 0,10$ & $31,96 \pm 0,12$ \\
\hline W3 & $23,13 \pm 0,06$ & $1,13 \pm 0,00$ & $7,15 \pm 0,08$ & $6,31 \pm 0,41$ & $18,93 \pm 0,06$ & $16,46 \pm 0,06$ \\
\hline W4 & $22,40 \pm 0,00$ & $0,07 \pm 0,00$ & $7,22 \pm 0,30$ & $6,34 \pm 0,66$ & $1,65 \pm 0,01$ & $0,99 \pm 0,04$ \\
\hline W5 & $23,30 \pm 0,00$ & $1,84 \pm 0,00$ & $6,35 \pm 0,36$ & $6,35 \pm 0,62$ & $29,47 \pm 0,15$ & $27,49 \pm 0,40$ \\
\hline CW1 & $23,70 \pm 0,00$ & $1,69 \pm 0,01$ & $6,87 \pm 0,16$ & $6,58 \pm 0,26$ & $27,23 \pm 0,12$ & $25,03 \pm 0,32$ \\
\hline CW2 & $24,20 \pm 0,00$ & $1,78 \pm 0,01$ & $7,05 \pm 0,24$ & $6,81 \pm 0,47$ & $28,57 \pm 0,23$ & $26,29 \pm 0,07$ \\
\hline CW3 & $27,50 \pm 0,26$ & $1,18 \pm 0,01$ & $7,21 \pm 0,10$ & $7,07 \pm 0,32$ & $19,57 \pm 0,15$ & $17,11 \pm 0,17$ \\
\hline CW4 & $24,53 \pm 0,06$ & $0,07 \pm 0,00$ & $7,82 \pm 0,18$ & $7,69 \pm 0,35$ & $1,65 \pm 0,02$ & $1,09 \pm 0,02$ \\
\hline CW5 & $24,03 \pm 0,06$ & $0,52 \pm 0,00$ & $6,74 \pm 0,20$ & $8,11 \pm 0,22$ & $9,41 \pm 0,09$ & $6,59 \pm 0,10$ \\
\hline
\end{tabular}

${ }^{1}$ As abreviaturas constam no início deste trabalho, na lista de abreviaturas.

Ainda conforme a Resolução no 357, águas salobras devem apresentar valores de $\mathrm{pH}$ entre 6,5 e 8,5 e oxigênio dissolvido acima de $5 \mathrm{mgL}^{-1}$ para condições de boa qualidade. De acordo com os resultados obtidos na tabela 8 para estes parâmetros, é possível afirmar que, em sua maioria, os valores estão dentro das exigências, com uma pequena discordância para os pontos 5 e 1 da Baixada Santista que apresentaram pH igual a 6,35 e DO igual a 4,68 $\mathrm{mgL}^{-1}$, respectivamente.

Não foram encontrados limites estabelecidos para valores de condutividade e sólidos totais dissolvidos para as amostras de águas salobras, apenas para águas doces. No entanto, uma relação entre valores de salinidade, sólidos totais dissolvidos e condutividade pode ser observada nas 
figuras 25 e 26, quando se compara os pontos de coleta na Baixada Santista e Cananéia, respectivamente.

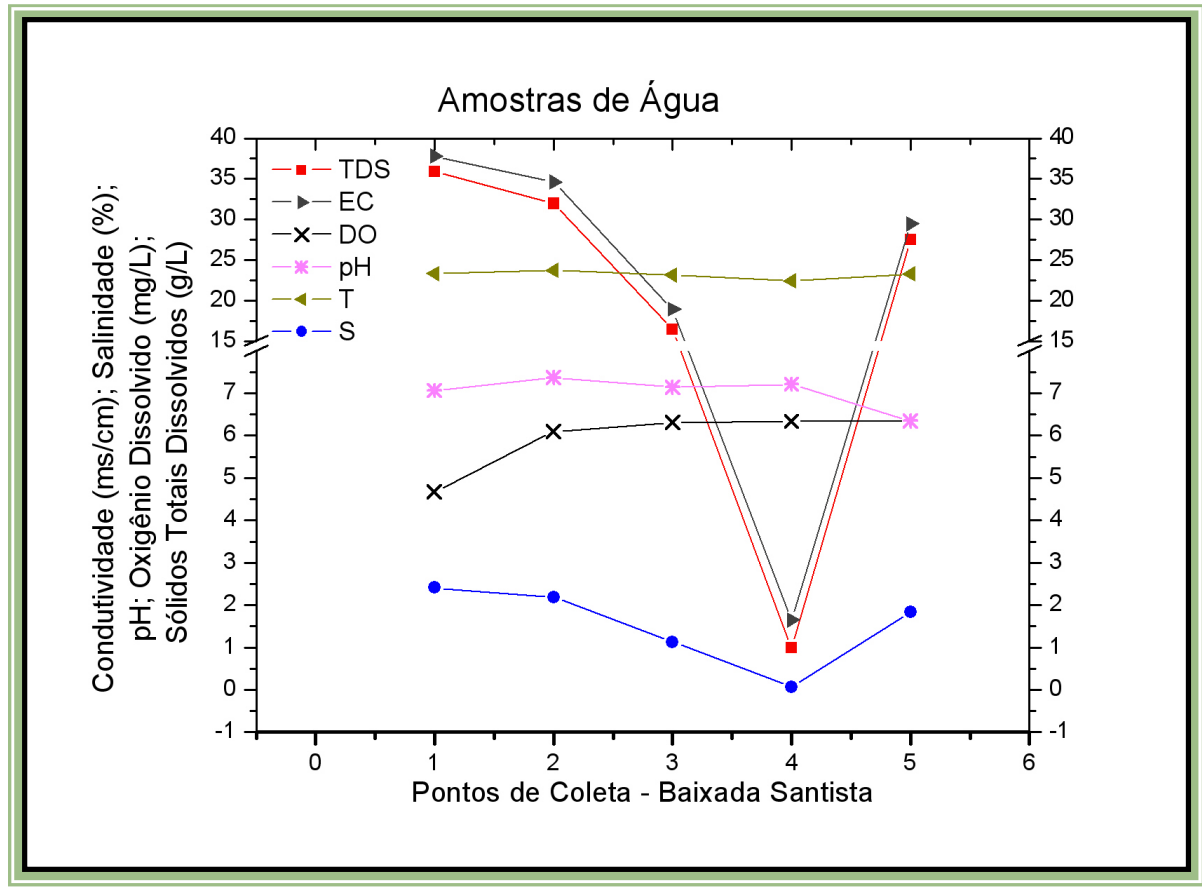

Figura 25: Gráfico de comparação dos parâmetros estudados em amostras de água em cinco pontos de coleta do complexo estuarino da Baixada Santista.

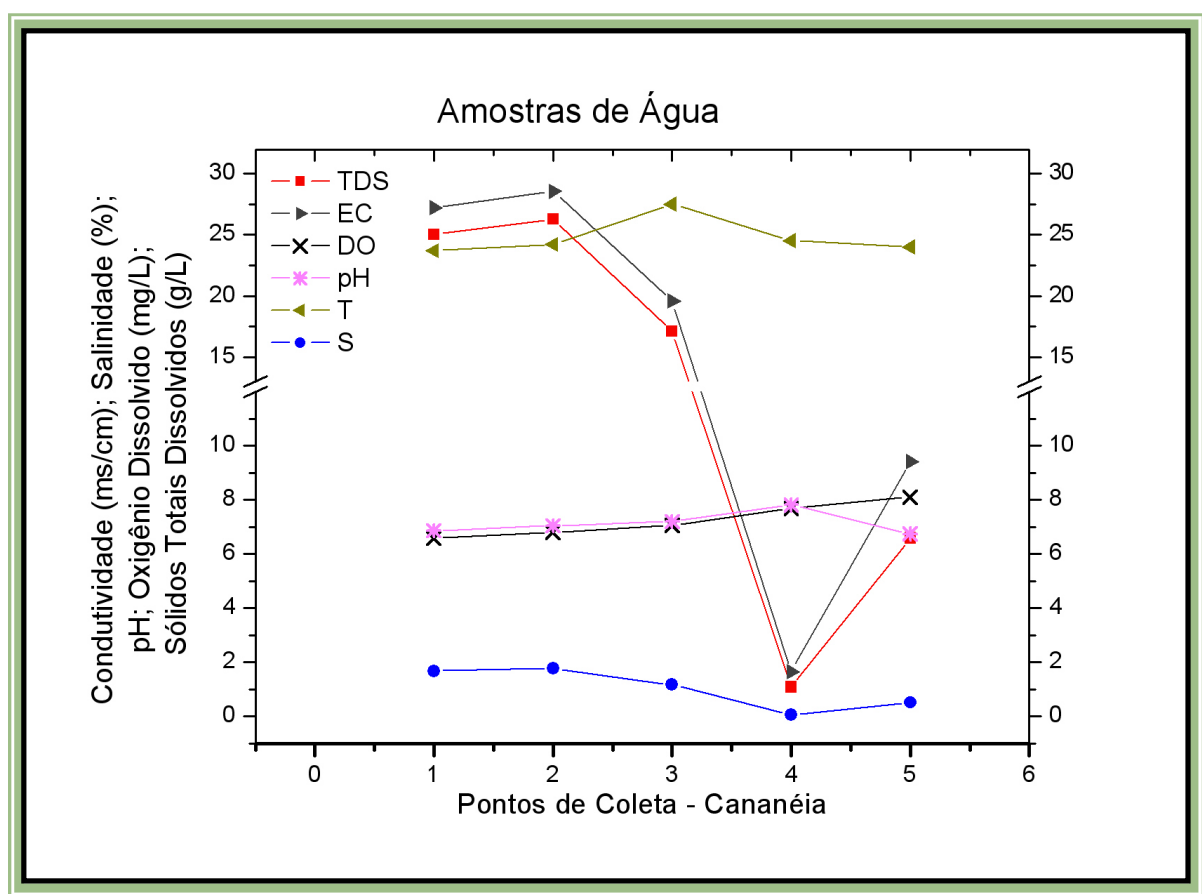

Figura 26: Gráfico de comparação dos parâmetros estudados em amostras de água em cinco pontos de coleta do complexo estuarino de Cananéia. 


\subsection{Caracterização das amostras de sedimento}

Os parâmetros obtidos para a caracterização das amostras de sedimentos estão apresentados na tabela 9.

Tabela 9: Caracterização das amostras de sedimento'.

\begin{tabular}{ccccccc}
\hline \multirow{2}{*}{ Amostra } & \multicolumn{5}{c}{ Parâmetros estudados nas amostras de sedimento } \\
\cline { 2 - 7 } & $\begin{array}{c}\text { OM } \\
\text { (\%) }\end{array}$ & $\begin{array}{c}\text { HA } \\
\text { (\%) }\end{array}$ & pH & $\begin{array}{c}\text { CEC } \\
\left(\mathbf{c m o l k g}^{-1}\right)\end{array}$ & $\begin{array}{c}\text { TOC } \\
\left.\text { (mgkg }^{-1}\right)\end{array}$ & $\begin{array}{c}\mathbf{H} \\
(\%)\end{array}$ \\
\hline S1 & $7,70 \pm 0,90$ & $1,03 \pm 0,04$ & $4,67 \pm 0,08$ & $5,37 \pm 0,74$ & $21,17 \pm 0,65$ & $42,89 \pm 1,54$ \\
\hline S2 & $7,06 \pm 0,40$ & $1,57 \pm 0,09$ & $6,75 \pm 0,04$ & $9,03 \pm 0,84$ & $28,71 \pm 2,60$ & $44,11 \pm 0,32$ \\
\hline S3 & $2,18 \pm 0,33$ & $0,24 \pm 0,02$ & $7,01 \pm 0,10$ & $4,47 \pm 0,21$ & $2,14 \pm 0,19$ & $27,15 \pm 0,40$ \\
\hline S4 & $13,47 \pm 0,87$ & $3,28 \pm 0,13$ & $5,81 \pm 0,04$ & $12,28 \pm 0,52$ & $59,22 \pm 2,86$ & $54,56 \pm 1,30$ \\
\hline S5 & $24,90 \pm 0,84$ & $3,09 \pm 0,23$ & $6,45 \pm 0,04$ & $18,29 \pm 1,40$ & $65,39 \pm 0,77$ & $72,62 \pm 0,23$ \\
\hline CS1 & $10,51 \pm 0,86$ & $1,62 \pm 0,18$ & $6,09 \pm 0,01$ & $11,28 \pm 0,46$ & $24,84 \pm 1,25$ & $51,84 \pm 6,85$ \\
\hline CS2 & $2,43 \pm 0,67$ & $0,69 \pm 0,04$ & $7,61 \pm 0,03$ & $5,21 \pm 0,13$ & $5,40 \pm 0,18$ & $28,60 \pm 0,64$ \\
\hline CS3 & $3,05 \pm 1,03$ & $0,62 \pm 0,13$ & $7,71 \pm 0,09$ & $7,21 \pm 0,25$ & $6,18 \pm 0,10$ & $32,30 \pm 4,10$ \\
\hline CS4 & $10,84 \pm 0,72$ & $1,96 \pm 0,11$ & $5,13 \pm 0,04$ & $11,97 \pm 0,14$ & $27,90 \pm 1,41$ & $54,53 \pm 1,25$ \\
\hline CS5 & $19,96 \pm 1,14$ & $3,78 \pm 0,28$ & $6,38 \pm 0,05$ & $17,62 \pm 1,10$ & $56,08 \pm 2,06$ & $62,08 \pm 1,08$ \\
\hline \hline
\end{tabular}

${ }^{1}$ As abreviaturas constam no início deste trabalho, na lista de abreviaturas.

O teor de umidade nos sedimentos de manguezais varia de acordo com a ação das marés, entretanto, este parâmetro influencia na disponibilidade de nutrientes e/ou substâncias tóxicas para as plantas, podendo estar relacionado com a capacidade de troca catiônica, o que pode ser observado nos resultados obtidos através das figuras 27 e 28 para a Baixada Santista e Cananéia, respectivamente.

Os valores de $\mathrm{pH}$ encontrados denominam estes sedimentos como levemente ácidos, porém, estes valores também sofrem variação pelas marés. Um ecossistema mais diversificado tanto em meio aeróbio como anaeróbio, corresponde a valores de $\mathrm{pH}$ próximos da neutralidade $(\mathrm{pH}=7)$ e os critérios de proteção à vida aquática estabelecem valores de $\mathrm{pH}$ entre 6 e 9. Sendo assim, os pontos 1 e 4 da Baixada Santista e 4 de Cananéia podem estar comprometidos se permanecerem nos valores encontrados. 


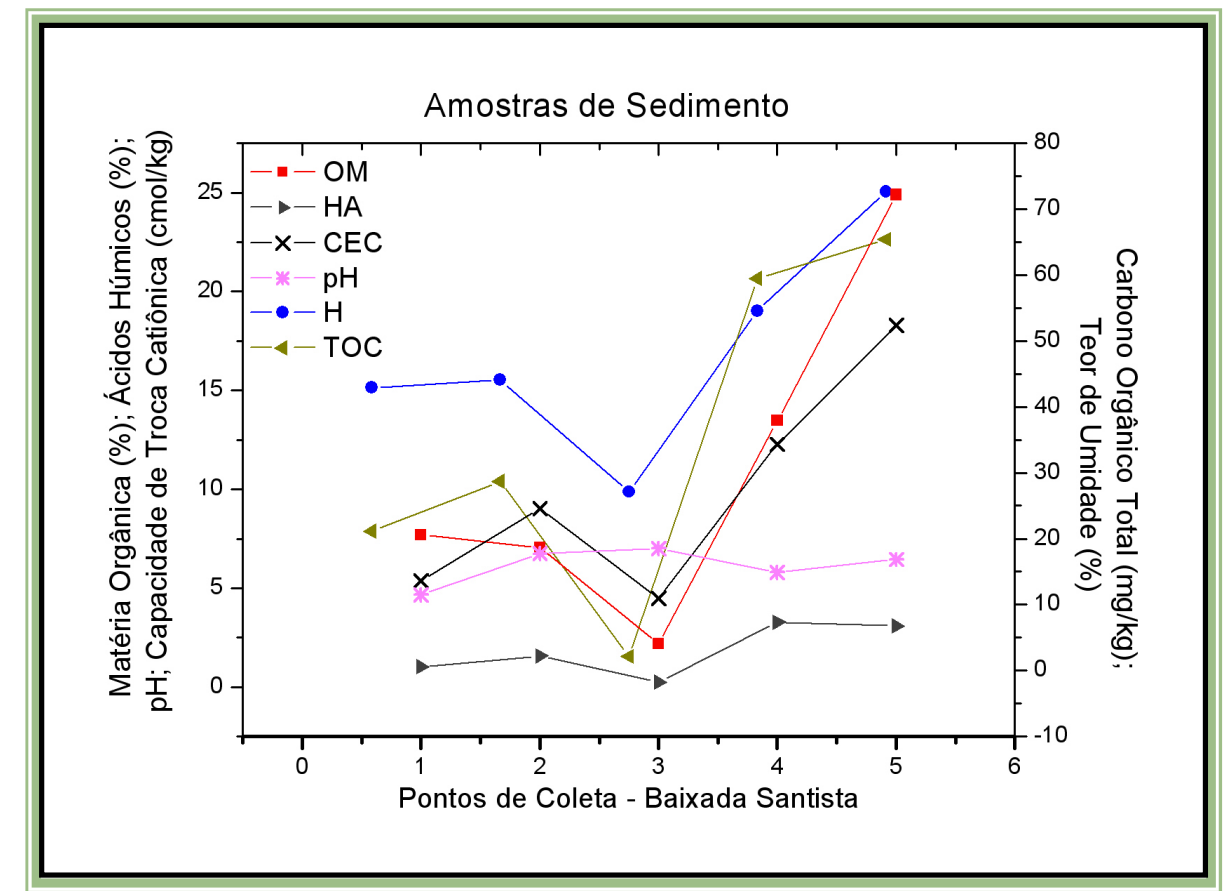

Figura 27: Gráfico de comparação dos parâmetros estudados em amostras de sedimento em cinco pontos de coleta do complexo estuarino da Baixada Santista.

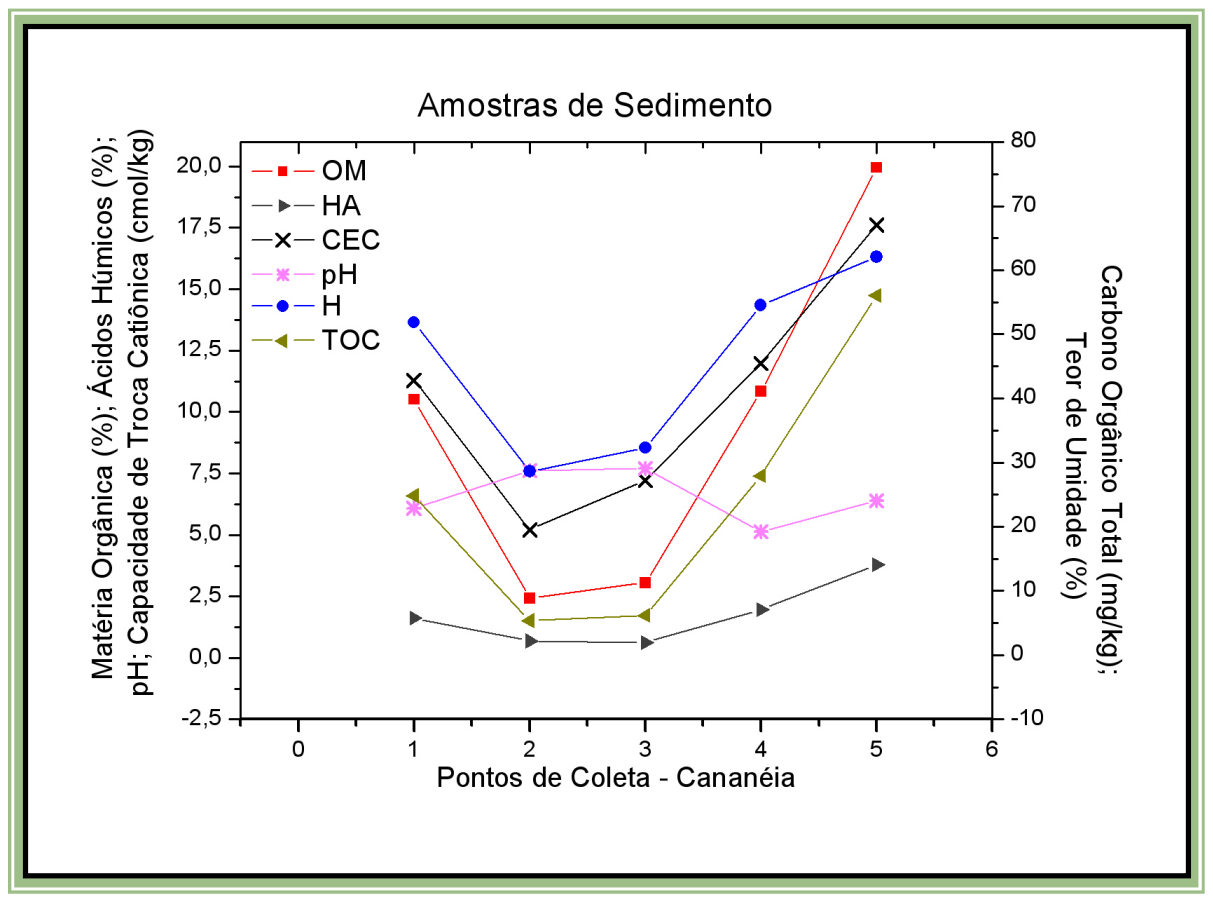

Figura 28: Gráfico de comparação dos parâmetros estudados em amostras de sedimento em cinco pontos de coleta do complexo estuarino de Cananéia. 
Com exceção do ponto 3 da Baixada Santista, os valores de capacidade de troca catiônica determinados na amostras de sedimento mostraram-se elevados, levando em consideração que valores acima de $5 \mathrm{cmolkg}^{-1}$ são citados como elevados pela literatura consultada. Através dos gráficos 27 e 28 é possível evidenciar uma relação entre a CEC e a matéria orgânica, o que leva a uma interpretação de que, com exceção do ponto 1 da Baixada Santista, a CEC pode ser proveniente da matéria orgânica.

A matéria orgânica variou muito nas amostras estudadas. As coletas foram realizadas nas embocaduras dos manguezais e a tendência é aumentar os valores de OM quando se adentra nestes ecossistemas. A OM também influencia na infiltração e retenção de água, o que pode ser verificado nas figuras 27 e 28 através da relação com a umidade, com exceção do ponto 1 da Baixada Santista.

Os teores de ácidos húmicos nas amostras de sedimentos apresentaram correlação direta com a umidade, a CEC, a OM e os teores de carbono orgânico total, com exceção do ponto 5 da Baixada Santista e do ponto 3 de Cananéia, que desviaram um pouco do esperado. Já os teores de carbono orgânico total, se mostraram em conformidade com o esperado ao se observar sua relação com os outros parâmetros exibidos nos gráficos apresentados nas figuras 27 e 28.

\subsection{Determinação de metais pseudo-totais em amostras de água, sedimento e folhas e raízes de mangues}

A determinação de metais pseudo-totais foi feita por ICP-AES e, conforme descrito no item 4.6.2, foram construídos gráficos de calibração com 5 concentrações distintas para cada metal, o que pode ser observado através da figura 29. 


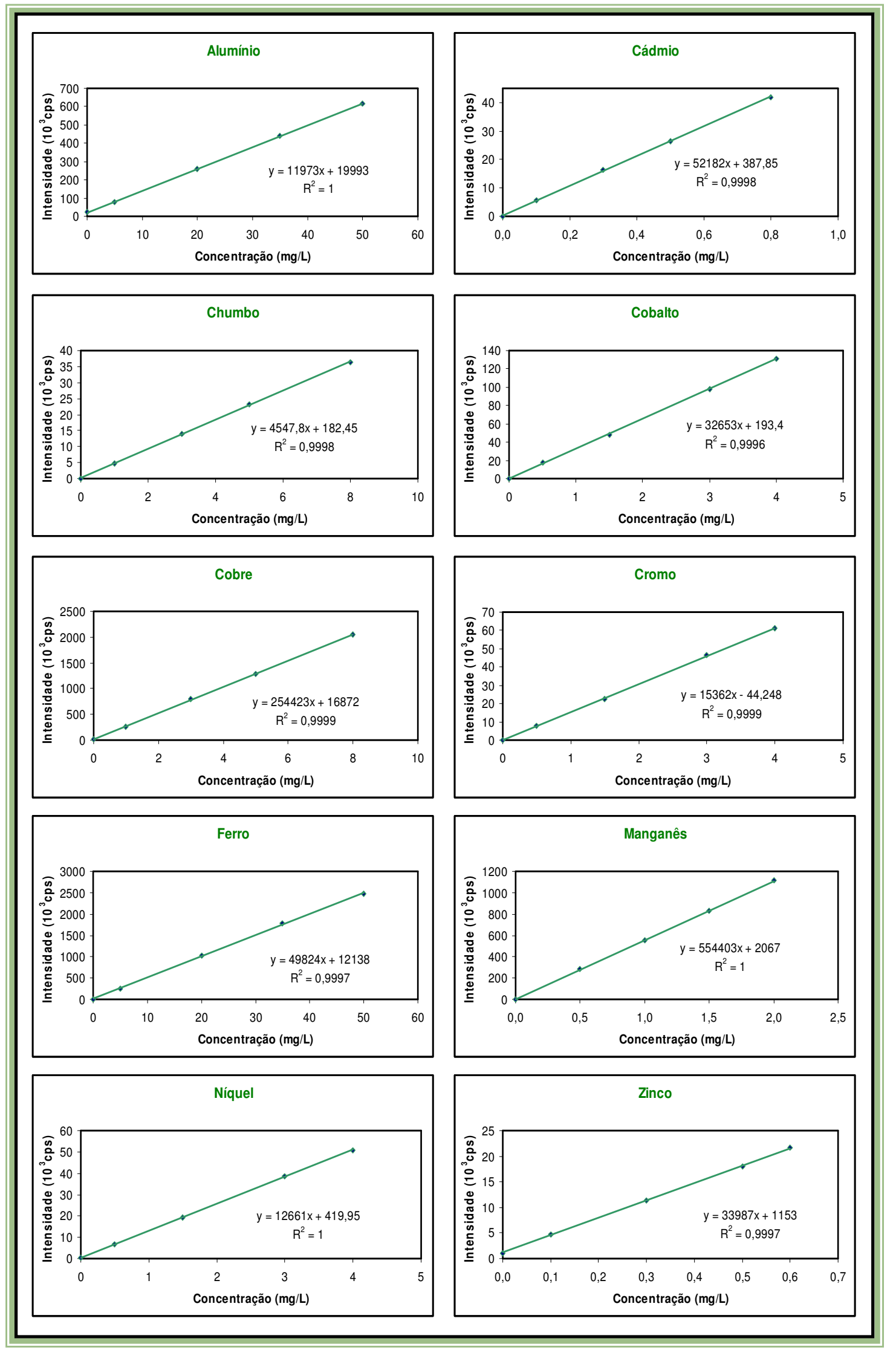

Figura 29: Gráficos de Calibração para a determinação de metais por ICP-AES. 
De acordo com a Resolução nํ 899 de 29/05/2003 da Agencia Nacional de Vigilância Sanitária (ANVISA), o critério mínimo aceitável para o coeficiente de correlação $\left(R^{2}\right)$ deve ser 0,99 . Sendo assim, pode ser observado na tabela 10 que os resultados são satisfatórios para este critério. Os valores de LOD e LOQ também podem ser observados na tabela 10 e, de acordo com os limites de tolerância estabelecidos por diferentes fontes consideradas neste trabalho, os LOD e LOQ encontrados são satisfatórios.

Tabela 10: Valores de $L O D$ e $L O Q$ encontrados e limites máximos permissíveis para metais a serem considerados neste estudo'.

\begin{tabular}{cccccccc}
\hline Metal & LOD & LOQ & $\begin{array}{c}\text { VRQ } \\
\text { (CETESB, } \\
\text { 2005) } \\
\text { (mgkg }\end{array}$ & $\begin{array}{c}\text { Lista } \\
\text { Holandesa } \\
\text { VR (S) }\end{array}$ & $\begin{array}{c}\text { Lista } \\
\text { Holandesa } \\
\text { VR (S) }\end{array}$ & $\begin{array}{c}\text { Canadian } \\
\text { Sediment } \\
\text { Quality } \\
\text { ISQG }\end{array}$ & $\begin{array}{c}\text { VMP } \\
\text { (CONAMA, } \\
\text { Res. 357) }\end{array}$ \\
\hline $\mathbf{A l}$ & 0,037 & 0,073 & - & - & - & - & 0,1 \\
\hline $\mathbf{C d}$ & 0,002 & 0,003 & 0,5 & 0,4 & 0,8 & 0,7 & 0,005 \\
\hline $\mathbf{P b}$ & 0,007 & 0,015 & 17 & 50 & 85 & 30,2 & 0,01 \\
\hline $\mathbf{C o}$ & 0,002 & 0,003 & 13 & 4 & 20 & - & - \\
\hline $\mathbf{C u}$ & 0,003 & 0,006 & 35 & 15 & 36 & 18,7 & 0,005 \\
\hline $\mathbf{C r}$ & 0,003 & 0,005 & 40 & 50 & 100 & 52,3 & 0,05 \\
\hline $\mathbf{F e}$ & 0,001 & 0,003 & - & - & - & - & 0,3 \\
\hline $\mathbf{M n}$ & 0,002 & 0,003 & - & - & - & - & 0,1 \\
\hline $\mathbf{N i}$ & 0,008 & 0,016 & 13 & 10 & 35 & - & 0,025 \\
\hline $\mathbf{Z n}$ & 0,003 & 0,005 & 60 & 50 & 140 & 124 & 0,09 \\
\hline
\end{tabular}

\footnotetext{
${ }^{1}$ As abreviaturas constam no início deste trabalho, na lista de abreviaturas;

${ }^{2}$ Lista Holandesa - valores de referência para solo com $0 \%$ de matéria orgânica;

${ }^{3}$ Lista Holandesa - valores de referência para solo com $10 \%$ de matéria orgânica.
}

Neste trabalho foram considerados como valores de referência de qualidade para os sedimentos, os valores estabelecidos pela CETESB, pela Lista Holandesa e pelo Canadian Sediment Quality Guidelines (tabela 10). A Lista Holandesa nos confere valores para solos isentos de matéria orgânica distintos dos valores de referencia para solos que contém $10 \%$ de matéria orgânica, assim, para os pontos 3 da Baixada Santista ( $O M=2,18$ \%) e 2 e 3 de Cananéia ( $\mathrm{MO}=2,43 \%$ e 3,05\%, respectivamente) foram considerados os 
valores estabelecidos para solos com $0 \%$ de OM, enquanto que para os outros pontos de coleta considerou-se os valores estabelecidos para solos com $10 \%$ de OM.

Para as amostras de água, os limites de tolerância considerados foram obtidos da Resolução no 357 do CONAMA. Entretanto, deve-se ressaltar que para os metais $\mathrm{Al}$, $\mathrm{Cu}$ e $\mathrm{Fe}$, os valores estabelecidos correspondem a parte dissolvida do metal, enquanto que neste trabalho quantificou-se metais pseudototais.

A tabela 11 mostra as concentrações de metais pseudo-totais nas amostras de sedimento e água dos complexos estuarinos estudados. Os resultados encontrados para as amostras de sedimento mostraram-se, em sua maioria, abaixo dos limites estabelecidos nas legislações consideradas, porém, deve-se considerar que para os metais $\mathrm{Al}, \mathrm{Fe}$ e $\mathrm{Mn}$ não há limites estabelecidos pelos órgãos competentes. Ainda assim, de acordo com a CETESB, o ponto 5 da Baixada Santista apresenta altas concentrações para 0 $\mathrm{Pb}$ e $\mathrm{Zn}$, enquanto que no ponto 5 de Cananéia se observa altas concentrações de $\mathrm{Pb}$. Apesar disso, estes valores estão abaixo dos valores estabelecidos pelo Canadian Sediment Quality Guidelines, a qual é a única legislação em questão que se aplica a sedimentos, enquanto que as outras se referem a solos.

Nas amostras de água, podem ser observados valores acima do estabelecido pelas legislações para os metais $\mathrm{Cr}$, Mn e $\mathrm{Zn}$ em alguns pontos de coleta (tabela 11), bem como para o $\mathrm{Al}$ e Fe ao considerar tais metais dissolvidos, uma vez que não há limites estabelecidos para estes em sua totalidade. 
Tabela 11: Concentrações de metais pseudo-totais encontradas em amostras de sedimento e água dos complexos estuarinos estudados ${ }^{1}$.

\begin{tabular}{|c|c|c|c|c|c|c|c|c|c|c|}
\hline \multirow{2}{*}{ Amostra } & \multicolumn{10}{|c|}{ Concentração de metais pseudo-totais em amostras de sedimento (mgkg de massa seca) e água (mgL $\left.{ }^{-1}\right)$} \\
\hline & Al & Cd & $\mathrm{Pb}$ & Co & $\mathrm{Cu}$ & $\mathrm{Cr}$ & $\mathrm{Fe}$ & Mn & $\mathrm{Ni}$ & $\mathrm{Zn}$ \\
\hline S1 & $13912,09 \pm 407,78$ & ND & $7,96 \pm 0,42$ & $4,89 \pm 0,10$ & $4,23 \pm 0,41$ & $15,06 \pm 0,56$ & $13911,85 \pm 238,35$ & $132,86 \pm 5,53$ & $1,88 \pm 0,10$ & $56,91 \pm 2,21$ \\
\hline S2 & $12689,86 \pm 102,53$ & ND & $9,85 \pm 0,48$ & $3,86 \pm 0,15$ & $5,76 \pm 0,29$ & $14,28 \pm 0,25$ & $10916,45 \pm 135,12$ & $84,05 \pm 2,09$ & $2,13 \pm 0,90$ & $39,17 \pm 0,71$ \\
\hline S3 & $10687,07 \pm 257,53$ & ND & $3,82 \pm 0,30$ & $5,01 \pm 0,20$ & $4,58 \pm 0,48$ & $14,39 \pm 1,24$ & $10353,68 \pm 62,81$ & $96,82 \pm 1,85$ & $6,10 \pm 0,60$ & $33,82 \pm 2,33$ \\
\hline S4 & $19683,43 \pm 1025,13$ & ND & $10,36 \pm 0,84$ & $4,05 \pm 0,17$ & $6,19 \pm 0,76$ & $20,00 \pm 2,25$ & $16315,83 \pm 697,60$ & $81,41 \pm 7,17$ & $1,73 \pm 0,21$ & $49,71 \pm 4,83$ \\
\hline S5 & $43557,36 \pm 1511,29$ & $0,30 \pm 0,00$ & $22,15 \pm 1,27$ & $9,66 \pm 0,25$ & $13,44 \pm 0,60$ & $39,27 \pm 1,00$ & $30626,72 \pm 1039,87$ & $407,70 \pm 10,02$ & $6,59 \pm 0,40$ & $75,50 \pm 2,09$ \\
\hline CS1 & $5971,57 \pm 391,19$ & ND & $3,93 \pm 0,16$ & $2,34 \pm 0,18$ & $2,53 \pm 0,35$ & $14,36 \pm 1,04$ & $3674,45 \pm 220,31$ & $34,63 \pm 1,35$ & $1,65 \pm 0,12$ & $27,07 \pm 2,96$ \\
\hline CS2 & $4762,29 \pm 367,28$ & ND & $3,56 \pm 0,21$ & $2,46 \pm 0,12$ & $2,73 \pm 0,30$ & $11,81 \pm 0,25$ & $3244,08 \pm 129,86$ & $59,75 \pm 1,54$ & $0,70 \pm 0,10$ & $18,57 \pm 1,33$ \\
\hline CS3 & $5508,48 \pm 169,33$ & ND & $4,03 \pm 0,26$ & $2,39 \pm 0,12$ & $1,29 \pm 0,09$ & $9,74 \pm 0,50$ & $3955,54 \pm 324,34$ & $53,28 \pm 1,65$ & $0,33 \pm 0,06$ & $15,54 \pm 0,81$ \\
\hline CS4 & $7611,70 \pm 513,84$ & ND & $10,18 \pm 0,78$ & $3,29 \pm 0,16$ & $3,02 \pm 0,20$ & $10,45 \pm 1,22$ & $7829,36 \pm 621,46$ & $57,04 \pm 2,60$ & ND & $20,60 \pm 0,67$ \\
\hline CS5 & $22183,97 \pm 722,34$ & ND & $25,01 \pm 1,17$ & $5,62 \pm 0,46$ & $10,01 \pm 0,22$ & $21,48 \pm 1,57$ & $18824,31 \pm 243,90$ & $112,42 \pm 4,24$ & $0,79 \pm 0,10$ & $42,45 \pm 1,25$ \\
\hline W1 & $12,33 \pm 0,26$ & ND & ND & ND & ND & $0,01 \pm 0,00$ & $3,28 \pm 0,30$ & $0,10 \pm 0,00$ & ND & $0,02 \pm 0,00$ \\
\hline W2 & $6,07 \pm 0,32$ & ND & ND & ND & ND & $0,01 \pm 0,00$ & $1,58 \pm 0,16$ & $0,07 \pm 0,00$ & ND & $0,04 \pm 0,00$ \\
\hline W3 & $3,06 \pm 0,38$ & ND & ND & ND & ND & $0,01 \pm 0,00$ & $0,61 \pm 0,04$ & $0,04 \pm 0,00$ & ND & $0,03 \pm 0,00$ \\
\hline W4 & $5,41 \pm 0,44$ & ND & ND & ND & ND & $0,02 \pm 0,00$ & $0,54 \pm 0,05$ & $0,04 \pm 0,00$ & ND & $0,03 \pm 0,00$ \\
\hline W5 & $1,97 \pm 0,07$ & ND & ND & ND & ND & $0,07 \pm 0,01$ & $0,46 \pm 0,07$ & $0,05 \pm 0,00$ & ND & $0,03 \pm 0,00$ \\
\hline CW1 & $5,50 \pm 0,11$ & ND & ND & ND & ND & $0,07 \pm 0,01$ & $0,84 \pm 0,06$ & $0,02 \pm 0,00$ & ND & $0,01 \pm 0,00$ \\
\hline CW2 & $9,20 \pm 0,71$ & ND & ND & ND & ND & $0,04 \pm 0,00$ & $2,59 \pm 0,23$ & $0,06 \pm 0,01$ & ND & $0,03 \pm 0,00$ \\
\hline CW3 & $16,97 \pm 1,35$ & ND & ND & ND & ND & $0,02 \pm 0,00$ & $5,16 \pm 0,22$ & $0,16 \pm 0,01$ & ND & $0,10 \pm 0,01$ \\
\hline CW4 & $5,24 \pm 0,30$ & ND & ND & ND & ND & $0,03 \pm 0,00$ & $2,26 \pm 0,12$ & $0,05 \pm 0,00$ & ND & $0,04 \pm 0,00$ \\
\hline CW5 & $8,48 \pm 0,55$ & ND & ND & ND & ND & $0,02 \pm 0,00$ & $2,92 \pm 0,11$ & $0,05 \pm 0,00$ & ND & $0,04 \pm 0,01$ \\
\hline
\end{tabular}

${ }^{1}$ As abreviaturas constam no início deste trabalho, na lista de abreviaturas.

: Valores acima de VRQ - CETESB

: Valores acima de VR(S) - Lista Holandesa

: Valores acima de ISQG - Canadian Sediment Quality Guidelines

: Valores acima de VMP - CONAMA 
Tabela 12: Concentrações de metais pseudo-totais encontradas em amostras de folhas de mangues dos complexos estuarinos estudados'.

\begin{tabular}{|c|c|c|c|c|c|c|c|c|c|c|}
\hline \multirow{2}{*}{ Amostra } & \multicolumn{10}{|c|}{ Concentração de metais pseudo-totais em amostras de folhas de mangue $\left(\mathrm{mgkg}^{-1}\right)$} \\
\hline & Al & Cd & $\mathbf{P b}$ & Co & $\mathrm{Cu}$ & $\mathrm{Cr}$ & $\mathrm{Fe}$ & Mn & $\mathrm{Ni}$ & Zn \\
\hline FA1 & $169,49 \pm 14,07$ & ND & $1,68 \pm 0,20$ & $0,46 \pm 0,06$ & $7,10 \pm 0,35$ & $1,78 \pm 0,11$ & $175,35 \pm 14,36$ & $128,16 \pm 2,37$ & ND & $33,18 \pm 3,31$ \\
\hline FL1 & $171,15 \pm 5,83$ & ND & ND & ND & $1,19 \pm 0,10$ & ND & $128,56 \pm 7,96$ & $44,96 \pm 4,44$ & $5,12 \pm 1,78$ & $10,24 \pm 0,34$ \\
\hline FA2 & $1131,10 \pm 85,87$ & ND & $1,66 \pm 0,11$ & $0,43 \pm 0,06$ & $1,56 \pm 0,35$ & $2,26 \pm, 031$ & $582,10 \pm 42,69$ & $110,16 \pm 5,10$ & ND & $37,41 \pm 2,58$ \\
\hline FL2 & $324,81 \pm 6,00$ & ND & ND & ND & ND & ND & $184,60 \pm 15,56$ & $44,21 \pm 3,13$ & $5,50 \pm 126$ & $7,52 \pm 0,90$ \\
\hline FR2 & $184,70 \pm 17,97$ & ND & ND & ND & ND & ND & $82,69 \pm 6,97$ & $298,91 \pm 22,12$ & $5,19 \pm 0,17$ & $3,73 \pm 0,52$ \\
\hline FA3 & $193,71 \pm 8,89$ & ND & $1,19 \pm 0,10$ & $0,36 \pm 0,06$ & $2,93 \pm 0,20$ & $1,81 \pm 0,11$ & $785,05 \pm 40,06$ & $114,30 \pm 3,64$ & ND & $19,36 \pm 2,37$ \\
\hline FL3 & $109,53 \pm 7,77$ & ND & ND & ND & ND & ND & $209,58 \pm 16,00$ & $29,86 \pm 1,07$ & $5,98 \pm 1,20$ & $5,98 \pm 0,40$ \\
\hline FR3 & $140,13 \pm 5,28$ & ND & ND & ND & $3,07 \pm 0,26$ & ND & $274,24 \pm 22,15$ & $224,74 \pm 17,93$ & $5,42 \pm 0,53$ & $4,46 \pm 0,31$ \\
\hline FA4 & $120,20 \pm 4,87$ & ND & $0,40 \pm 0,10$ & $0,23 \pm 0,06$ & $0,70 \pm 0,10$ & $1,53 \pm 0,15$ & $225,99 \pm 10,60$ & $64,74 \pm 0,40$ & ND & $21,40 \pm 2,39$ \\
\hline FL4 & $119,83 \pm 4,45$ & ND & ND & ND & ND & ND & $142,92 \pm 6,41$ & $35,95 \pm 1,25$ & $5,97 \pm 0,69$ & $12,71 \pm 0,84$ \\
\hline FR4 & $130,84 \pm 5,49$ & ND & ND & ND & ND & ND & $74,91 \pm 5,17$ & $191,33 \pm 4,98$ & $5,33 \pm 0,64$ & $3,58 \pm 0,25$ \\
\hline FA5 & $178,19 \pm 3,15$ & ND & $0,59 \pm 0,10$ & $0,33 \pm 0,06$ & $3,58 \pm 0,15$ & $1,64 \pm 0,15$ & $271,72 \pm 22,09$ & $131,59 \pm 2,54$ & ND & $22,51 \pm 2,15$ \\
\hline FL5 & $129,38 \pm 3,39$ & ND & ND & ND & ND & ND & $151,06 \pm 13,66$ & $44,05 \pm 2,32$ & $5,93 \pm 0,20$ & $11,42 \pm 0,74$ \\
\hline FR5 & $181,97 \pm 14,22$ & ND & ND & ND & ND & ND & $114,32 \pm 7,63$ & $223,11 \pm 6,08$ & $5,06 \pm 0,37$ & $3,84 \pm 0,18$ \\
\hline CFA1 & $93,73 \pm 4,36$ & ND & ND & ND & $0,63 \pm 0,05$ & ND & $35,14 \pm 2,72$ & $126,46 \pm 6,99$ & $3,95 \pm 0,38$ & $6,34 \pm 0,41$ \\
\hline CFL1 & $196,89 \pm 10,96$ & ND & ND & ND & ND & ND & $75,68 \pm 1,42$ & $23,96 \pm 0,13$ & $2,73 \pm 0,26$ & $8,55 \pm 0,56$ \\
\hline CFR1 & $71,80 \pm 5,64$ & ND & ND & ND & ND & ND & $16,11 \pm 1,06$ & $127,97 \pm 11,66$ & $1,72 \pm 0,06$ & $1,96 \pm 0,12$ \\
\hline CFA2 & $90,01 \pm 8,65$ & ND & ND & ND & ND & ND & $47,78 \pm 2,45$ & $102,67 \pm 3,93$ & $4,30 \pm 0,35$ & $9,83 \pm 0,47$ \\
\hline CFL2 & $274,09 \pm 7,55$ & ND & ND & ND & ND & ND & $148,58 \pm 7,06$ & $24,96 \pm 0,72$ & $2,91 \pm 0,04$ & $6,50 \pm 0,28$ \\
\hline CFR2 & $88,34 \pm 4,67$ & ND & ND & ND & ND & ND & $27,07 \pm 1,65$ & $128,39 \pm 5,58$ & $1,59 \pm 0,11$ & $2,28 \pm 0,10$ \\
\hline CFA3 & $123,45 \pm 8,51$ & ND & ND & ND & $2,57 \pm 0,10$ & ND & $116,83 \pm 8,39$ & $163,55 \pm 9,19$ & $3,49 \pm 0,48$ & $13,49 \pm 0,22$ \\
\hline CFL3 & $139,41 \pm 6,74$ & ND & ND & ND & ND & ND & $68,81 \pm 4,99$ & $30,32 \pm 1,62$ & $2,93 \pm 0,16$ & $9,36 \pm 0,51$ \\
\hline CFR3 & $125,02 \pm 3,49$ & ND & ND & ND & ND & ND & $42,82 \pm 0,78$ & $394,97 \pm 17,81$ & $1,45 \pm 0,14$ & $1,06 \pm 0,03$ \\
\hline CFL4 & $196,07 \pm 11,28$ & ND & ND & ND & ND & ND & $232,74 \pm 14,20$ & $77,91 \pm 2,77$ & $2,95 \pm 0,17$ & $15,60 \pm 1,21$ \\
\hline CFR4 & $81,41 \pm 4,76$ & ND & ND & ND & ND & ND & $23,74 \pm 1,03$ & $523,49 \pm 5,28$ & $1,61 \pm 0,12$ & $1,45 \pm 0,21$ \\
\hline CFA5 & $100,24 \pm 2,65$ & ND & ND & ND & $0,23 \pm 0,06$ & ND & $55,22 \pm 5,68$ & $105,67 \pm 1,90$ & $3,79 \pm 0,33$ & $16,06 \pm 0,73$ \\
\hline CFL5 & $78,34 \pm 4,40$ & ND & ND & ND & ND & ND & $155,11 \pm 10,37$ & $71,44 \pm 2,13$ & $2,99 \pm 0,30$ & $13,73 \pm 0,18$ \\
\hline CFR5 & $97,05 \pm 9,59$ & ND & ND & ND & ND & ND & $41,98 \pm 2,77$ & $387,73 \pm 13,75$ & $1,68 \pm 0,00$ & $2,19 \pm 0,08$ \\
\hline
\end{tabular}

${ }^{1}$ As abreviaturas constam no início deste trabalho, na lista de abreviaturas. 
Tabela 13: Concentrações de metais pseudo-totais encontradas em amostras de raízes de mangues dos complexos estuarinos estudados'.

\begin{tabular}{|c|c|c|c|c|c|c|c|c|c|c|}
\hline \multirow{2}{*}{ Amostra } & \multicolumn{10}{|c|}{ Concentração de metais pseudo-totais em amostras de raízes de mangue $\left(\mathrm{mgkg}^{-1}\right)$} \\
\hline & Al & Cd & $\mathrm{Pb}$ & Co & $\mathrm{Cu}$ & $\mathrm{Cr}$ & $\mathrm{Fe}$ & Mn & $\mathrm{Ni}$ & Zn \\
\hline RA1 & $2443,89 \pm 69,99$ & ND & ND & ND & $4,24 \pm 0,22$ & $1,09 \pm 0,11$ & $1525,86 \pm 158,32$ & $136,77 \pm 5,56$ & $2,32 \pm 0,27$ & $12,12 \pm 0,81$ \\
\hline RL1 & $102,14 \pm 8,88$ & ND & ND & ND & ND & ND & $8,67 \pm 0,40$ & $29,83 \pm 1,65$ & $1,29 \pm 0,10$ & $1,02 \pm 0,06$ \\
\hline RA2 & $2318,12 \pm 54,42$ & ND & ND & ND & $0,69 \pm 0,10$ & $1,19 \pm 0,19$ & $1599,49 \pm 90,61$ & $139,46 \pm 6,70$ & $2,14 \pm 0,17$ & $13,38 \pm 1,46$ \\
\hline RL2 & $3861,65 \pm 85,42$ & ND & ND & ND & $2,94 \pm 0,16$ & $1,58 \pm 0,09$ & $2557,54 \pm 228,89$ & $341,28 \pm 12,36$ & $3,17 \pm 0,21$ & $14,32 \pm 0,61$ \\
\hline RR2 & $1467,25 \pm 41,92$ & ND & ND & ND & $1,55 \pm 0,05$ & ND & $973,30 \pm 26,22$ & $152,96 \pm 2,18$ & $0,92 \pm 0,05$ & $7,63 \pm 1,19$ \\
\hline RA3 & $3338,64 \pm 92,29$ & ND & ND & $0,92 \pm 0,05$ & $4,61 \pm 0,10$ & $1,84 \pm 0,14$ & $2606,78 \pm 114,82$ & $903,09 \pm 25,02$ & $2,90 \pm 0,09$ & $16,87 \pm 0,59$ \\
\hline RL3 & $880,57 \pm 23,77$ & ND & ND & ND & ND & ND & $709,16 \pm 38,73$ & $58,03 \pm 2,56$ & $2,42 \pm 0,16$ & $7,92 \pm 0,70$ \\
\hline RR3 & $1584,98 \pm 22,24$ & ND & ND & $0,13 \pm 0,06$ & $3,53 \pm 0,21$ & ND & $1255,20 \pm 68,14$ & $478,07 \pm 48,68$ & $1,84 \pm 0,10$ & $11,30 \pm 0,73$ \\
\hline RA4 & $4217,16 \pm 145,12$ & ND & ND & ND & $1,49 \pm 0,10$ & $0,56 \pm 0,06$ & $2615,73 \pm 123,79$ & $69,07 \pm 4,75$ & $1,58 \pm 0,09$ & $19,25 \pm 1,04$ \\
\hline RL4 & $8751,76 \pm 323,45$ & ND & ND & $0,13 \pm 0,06$ & $2,22 \pm 0,15$ & $3,15 \pm 0,25$ & $4387,64 \pm 126,00$ & $126,45 \pm 1,56$ & $1,29 \pm 0,10$ & $16,00 \pm 0,81$ \\
\hline RR4 & $1270,69 \pm 52,97$ & ND & ND & ND & $0,46 \pm 0,15$ & ND & $778,53 \pm 72,98$ & $151,95 \pm 4,27$ & $0,76 \pm 0,06$ & $8,89 \pm 0,54$ \\
\hline RA5 & $4106,77 \pm 148,91$ & ND & ND & ND & $4,65 \pm 0,07$ & $1,81 \pm 0,01$ & $2799,43 \pm 80,84$ & $180,92 \pm 6,49$ & $2,01 \pm 0,07$ & $19,18 \pm 1,01$ \\
\hline RL5 & $3869,80 \pm 182,11$ & ND & ND & ND & $3,70 \pm 0,07$ & $1,98 \pm 0,09$ & $2409,41 \pm 211,23$ & $256,06 \pm 12,77$ & $1,22 \pm 0,06$ & $15,14 \pm 1,40$ \\
\hline RR5 & $904,28 \pm 41,21$ & ND & ND & ND & ND & ND & $501,83 \pm 21,75$ & $41,79 \pm 1,80$ & $0,86 \pm 0,06$ & $6,81 \pm 0,61$ \\
\hline CRA1 & $1307,03 \pm 9,71$ & ND & ND & ND & $0,66 \pm 0,05$ & ND & $578,92 \pm 28,28$ & $41,00 \pm 3,03$ & $0,50 \pm 0,10$ & $13,64 \pm 1,00$ \\
\hline CRL1 & $683,76 \pm 38,06$ & ND & ND & ND & ND & ND & $379,13 \pm 15,07$ & $31,63 \pm 3,04$ & ND & $5,40 \pm 0,23$ \\
\hline CRR1 & $383,11 \pm 13,23$ & ND & ND & ND & ND & ND & $193,40 \pm 12,72$ & $24,47 \pm 1,80$ & ND & $3,71 \pm 0,15$ \\
\hline CRA2 & $1343,06 \pm 125,14$ & ND & ND & ND & $0,46 \pm 0,06$ & ND & $925,83 \pm 78,07$ & $45,92 \pm 4,37$ & $0,60 \pm 0,10$ & $8,42 \pm 0,41$ \\
\hline CRL2 & $1698,71 \pm 41,22$ & ND & ND & $1,42 \pm 0,14$ & $0,82 \pm 0,06$ & $1,52 \pm 0,10$ & $1896,59 \pm 46,65$ & $105,58 \pm 6,53$ & ND & $8,91 \pm 0,53$ \\
\hline CRR2 & $457,87 \pm 23,49$ & ND & ND & ND & ND & ND & $501,46 \pm 9,65$ & $56,80 \pm 4,96$ & ND & $2,91 \pm 0,17$ \\
\hline CRA3 & $2165,68 \pm 89,10$ & ND & ND & ND & $2,52 \pm 0,05$ & $0,60 \pm 0,10$ & $1317,87 \pm 59,72$ & $115,89 \pm 5,93$ & $0,66 \pm 0,06$ & $8,71 \pm 0,25$ \\
\hline CRL3 & $1228,20 \pm 32,94$ & ND & ND & ND & $2,55 \pm 0,15$ & $1,82 \pm 0,05$ & $681,00 \pm 12,03$ & $76,07 \pm 4,58$ & $0,99 \pm 0,10$ & $3,28 \pm 0,29$ \\
\hline CRR3 & $1131,29 \pm 60,08$ & ND & ND & ND & $0,73 \pm 0,06$ & $1,88 \pm 0,09$ & $773,07 \pm 48,02$ & $76,75 \pm 4,65$ & ND & $3,73 \pm 0,30$ \\
\hline CRL4 & $2094,53 \pm 96,22$ & ND & ND & ND & $1,58 \pm 0,09$ & $3,17 \pm 0,10$ & $2097,96 \pm 128,29$ & $56,36 \pm 2,80$ & ND & $3,23 \pm 0,20$ \\
\hline CRR4 & $562,75 \pm 46,59$ & ND & ND & ND & $1,13 \pm 0,15$ & $1,19 \pm 0,10$ & $272,61 \pm 19,98$ & $47,49 \pm 2,94$ & ND & $2,59 \pm 0,10$ \\
\hline CRA5 & $2283,39 \pm 81,68$ & ND & ND & ND & $3,35 \pm 0,08$ & $0,10 \pm 0,00$ & $1338,70 \pm 39,58$ & $156,70 \pm 12,88$ & $0,33 \pm 0,06$ & $16,86 \pm 1,32$ \\
\hline CRL5 & $2772,58 \pm 23,03$ & ND & ND & ND & $3,62 \pm 0,17$ & $2,44 \pm 0,15$ & $2390,70 \pm 114,29$ & $44,86 \pm 2,55$ & ND & $7,54 \pm 0,31$ \\
\hline CRR5 & $1179,96 \pm 91,13$ & ND & ND & ND & $1,29 \pm 0,10$ & $2,11 \pm 0,15$ & $741,26 \pm 35,14$ & $32,52 \pm 1,20$ & ND & $2,35 \pm 0,12$ \\
\hline
\end{tabular}

${ }^{1}$ As abreviaturas constam no início deste trabalho, na lista de abreviaturas. 
As tabelas 12 e 13 exibem os valores de concentrações de metais pseudo-totais obtidos para as amostras de folhas e raízes das três espécies de mangue estudadas, respectivamente. Não foram observados valores de concentrações para as espécies Rhizophora mangle no ponto 1 da Baixada Santista e para a Avicennia schaueriana no ponto 4 de Cananéia, uma vez que não houve determinação alguma nestes casos, devido a ausência destas plantas nas proximidades dos referentes pontos de coleta.

Não foram encontradas legislações específicas para as plantas de mangue, conferindo uma impossibilidade de comparação dos resultados obtidos com valores de referência para as concentrações de metais. No entanto, pode ser observada a presença de metais como $\mathrm{Pb}$ e $\mathrm{Cr}$ em algumas amostras de folhas dos mangues estudados (tabela 12), o que pode acarretar em um risco para estas plantas e para as espécies que delas se alimentam.

$\mathrm{Na}$ tentativa de comparar o comportamento dos metais, uns com os outros, em pontos de coleta distintos, segue abaixo uma seqüência de gráficos com os resultados obtidos.

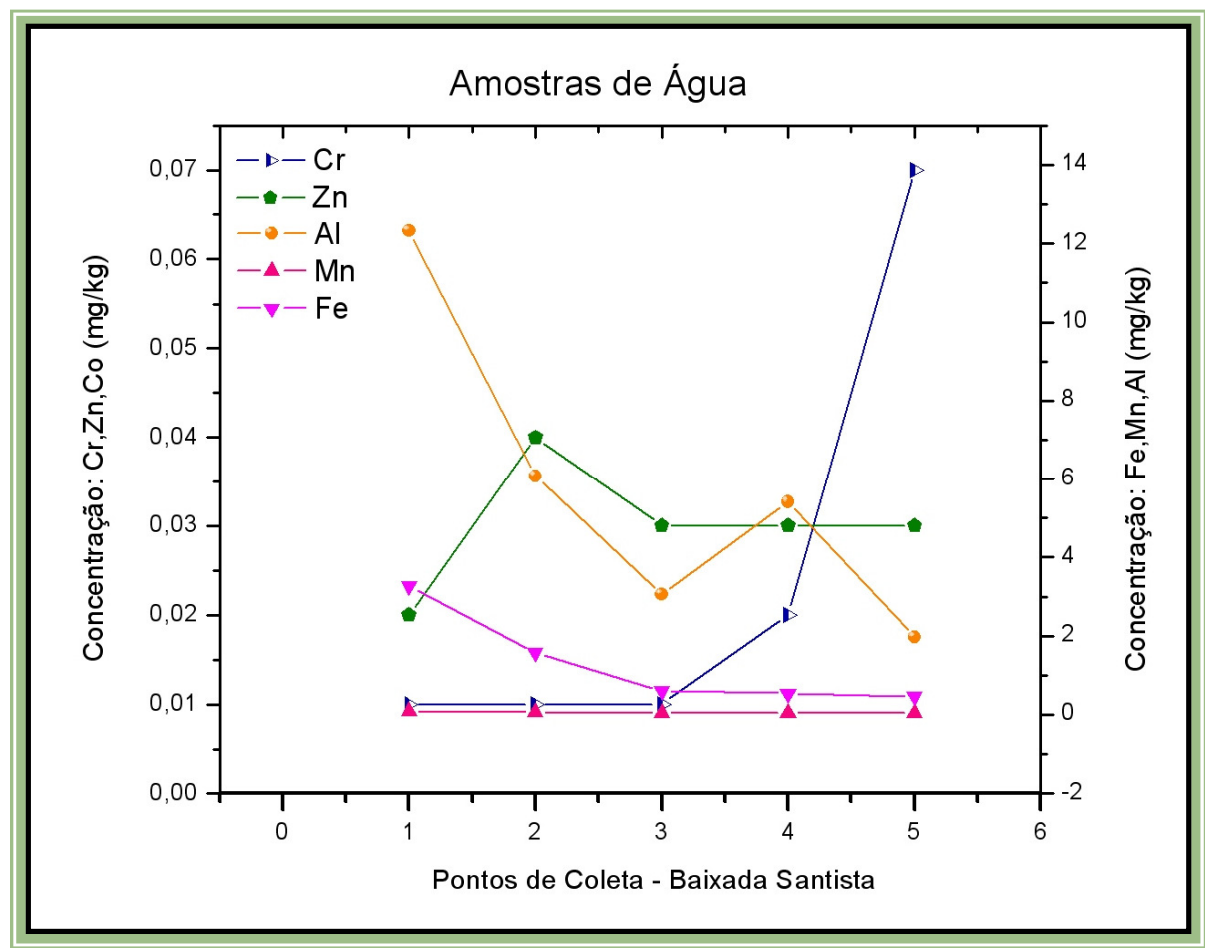

Figura 30: Gráfico de comparação das concentrações de metais pseudo-totais em amostras de água em cinco pontos de coleta do complexo estuarino da Baixada Santista. 
Nas amostras de água do complexo estuarino da Baixada Santista, em geral, não foi destacada uma correlação direta nos resultados obtidos, porém foram feitas algumas observações como, por exemplo, para o metal Al que demonstrou ter maior concentração no ponto 1, exatamente como o esperado, uma vez que este oferece o menor $\mathrm{pH}$ dentre os outros (figura 30). Nas amostras de água da região de Cananéia, entretanto, com exceção do $\mathrm{Cr}$, os metais encontrados apresentaram o mesmo comportamento (figura 31). Ainda assim, não se notou alguma relação direta destes com os parâmetros determinados na caracterização das amostras de água, exceto o ponto 3 que apresenta maior temperatura e maior quantidade de metais também.

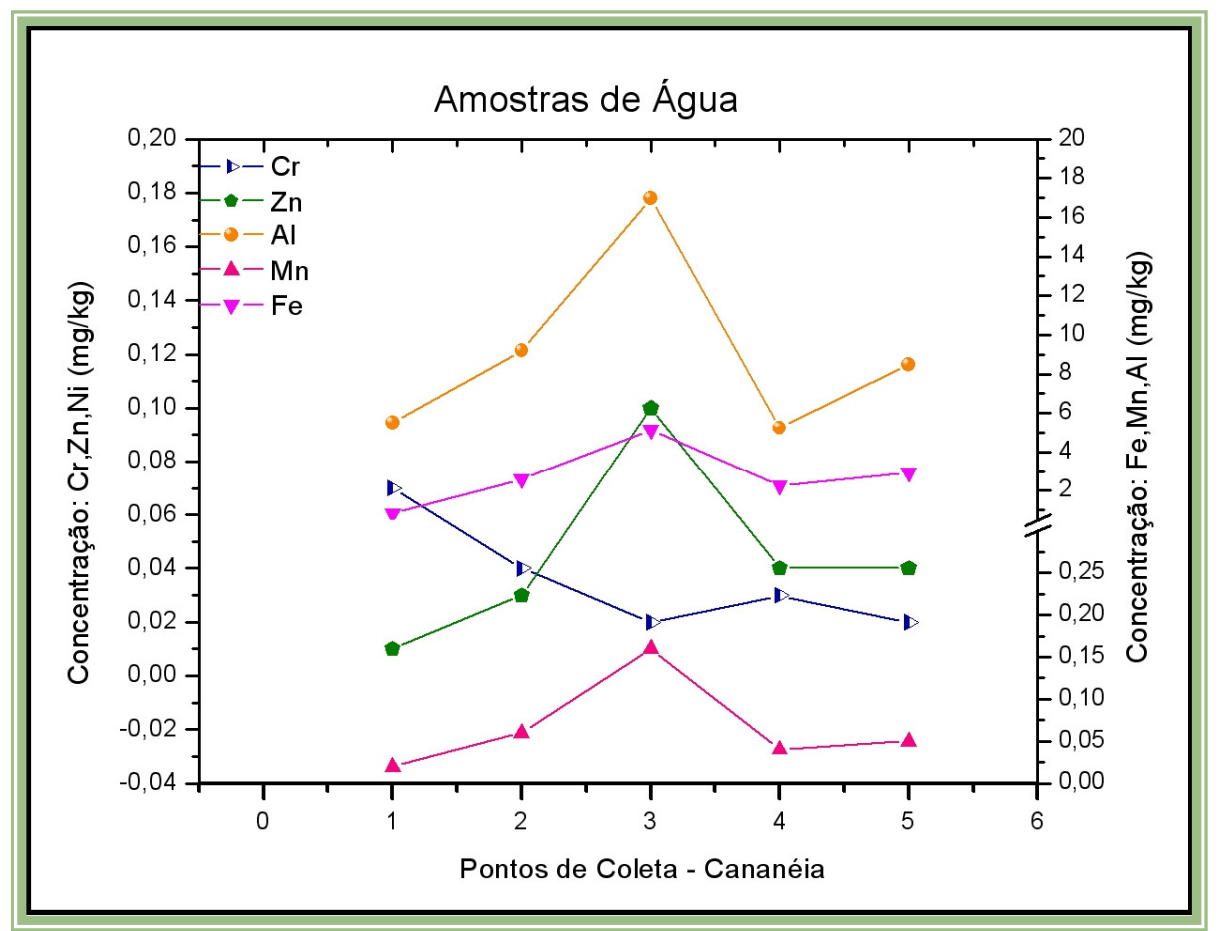

Figura 31: Gráfico de comparação das concentrações de metais pseudo-totais em amostras de água em cinco pontos de coleta do complexo estuarino de Cananéia.

As amostras de sedimento da Baixada Santista apresentaram resultados coincidentes para alguns metais, onde o comportamento de $\mathrm{Zn}, \mathrm{Fe}, \mathrm{Al}, \mathrm{Cr}$, Co e $\mathrm{Mn}$ estão diretamente relacionados com a $\mathrm{OM}$, bem como os metais $\mathrm{Pb}$ e $\mathrm{Cu}$ que estão diretamente relacionados com a CEC. No entanto, a OM e a CEC estão diretamente relacionadas nos pontos 2, 3, 4 e 5, discordando apenas no ponto 1 de coleta. 


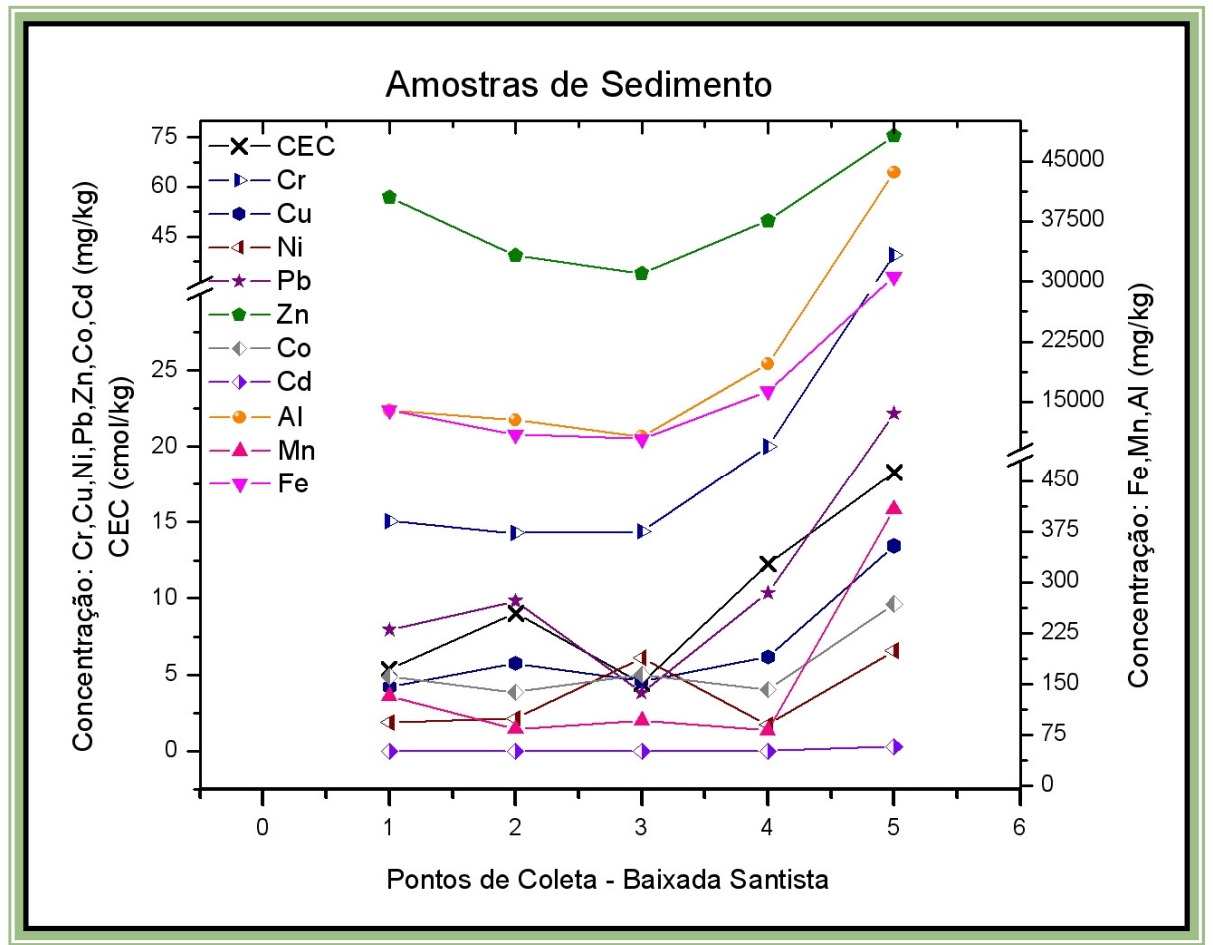

Figura 32: Gráfico de comparação das concentrações de metais pseudo-totais em amostras de sedimento em cinco pontos de coleta do complexo estuarino da Baixada Santista.

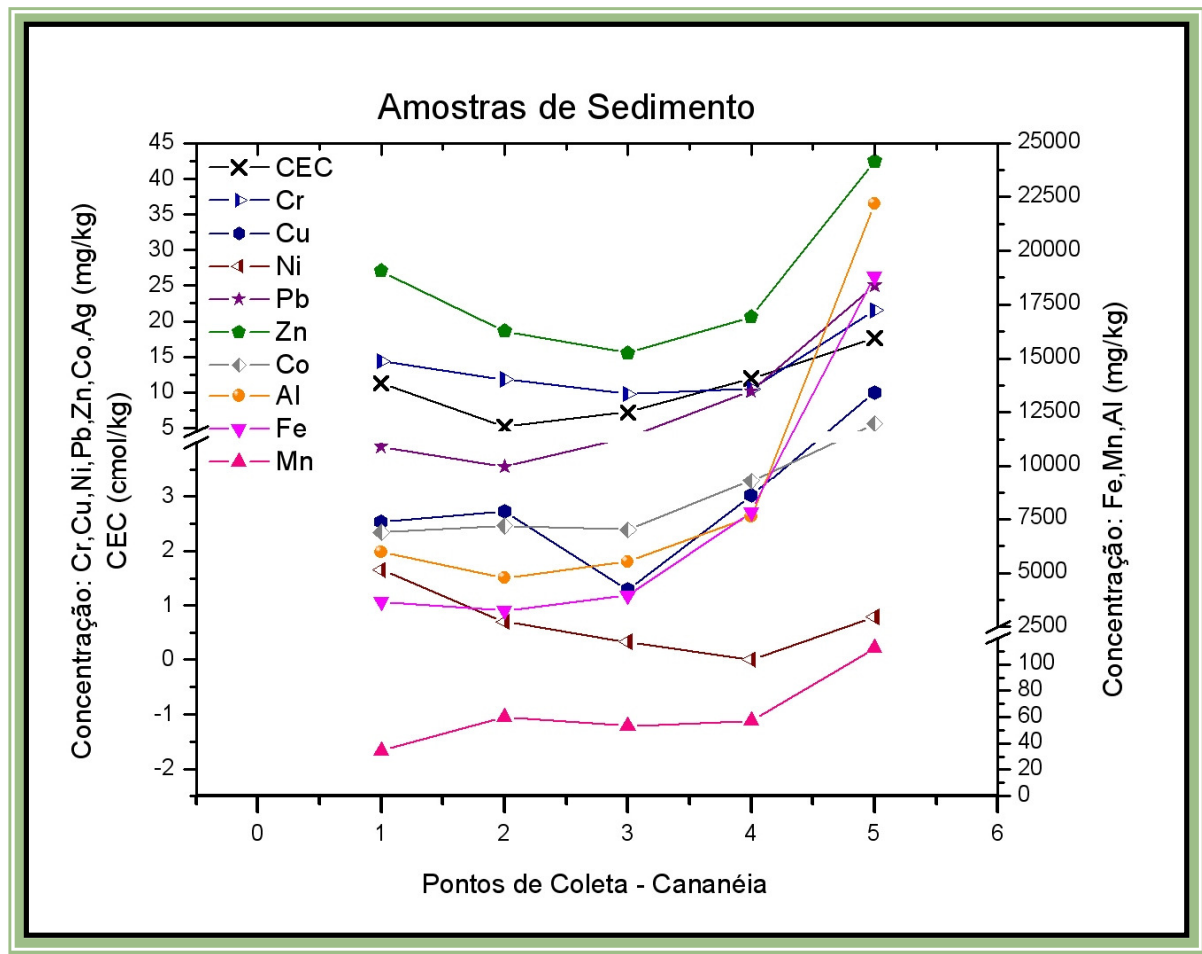

Figura 33: Gráfico de comparação das concentrações de metais pseudo-totais em amostras de sedimento em cinco pontos de coleta do complexo estuarino de Cananéia. 
Na região de Cananéia, as amostras de sedimento apresentaram metais com comportamento similar a $\mathrm{OM}$ e a CEC, como o Al, Fe e Pb. Para os outros metais presentes, foi possível observar que ocorreram algumas pequenas variações dos resultados esperados ao se comparar com os parâmetros estudados, como por exemplo os pontos 1 e 3, entretanto, de maneira geral, foram obtidos resultados semelhantes, o que pode ser visto na figura 33.

Nos gráficos que representam as concentrações de metais pseudo-totais em folhas e raízes de mangues, foi possível observar que, embora alguns metais distintos se comportem da mesma maneira em uma matriz, seja ela folha ou raiz, não há como generalizar a relação destes com as características do sedimento, pois ocorre uma notável aleatoriedade nos resultados, tanto na região da Baixada Santista como na região de Cananéia, o que pode ser visto nas figuras 34 à 45 .

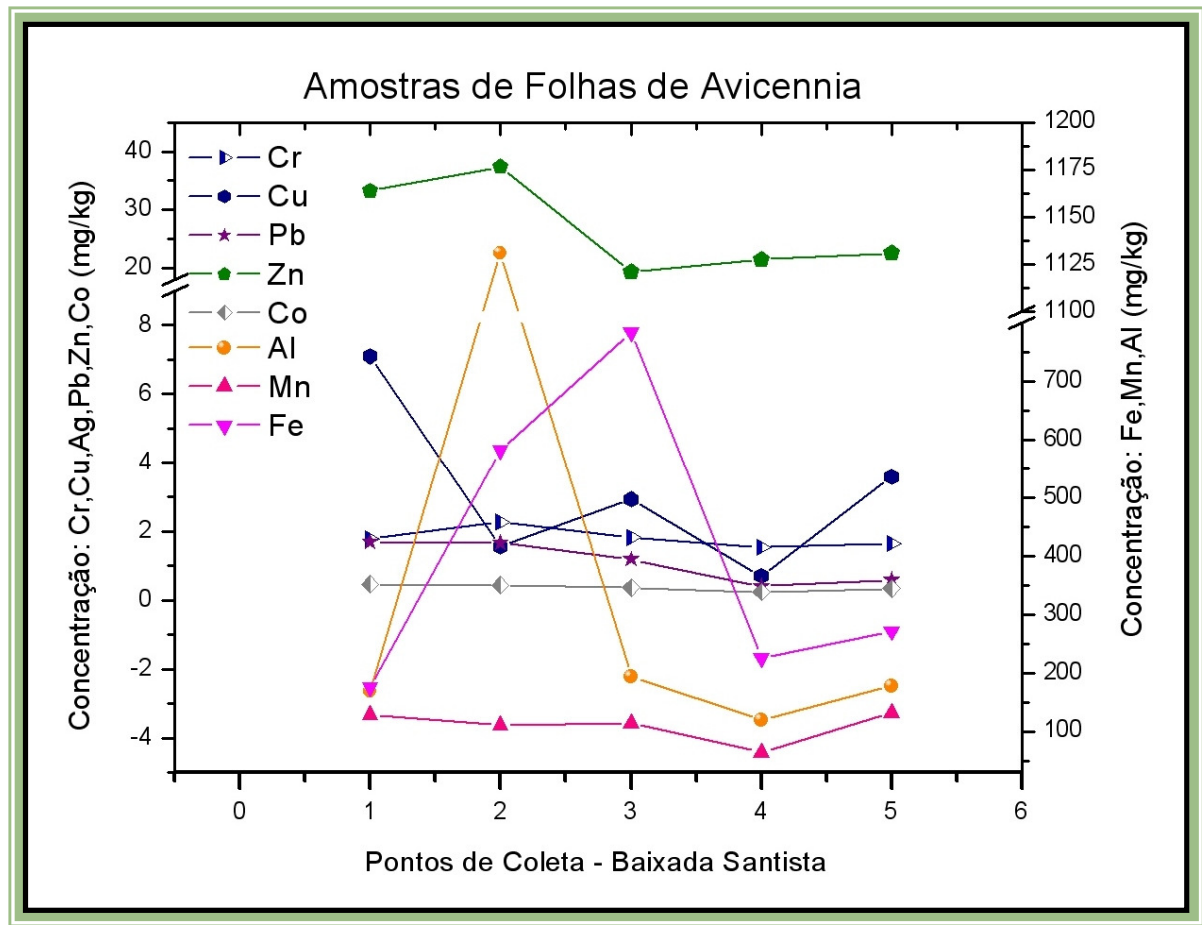

Figura 34: Gráfico de comparação das concentrações de metais pseudo-totais em amostras de folhas de Avicennia schaueriana (mangue preto) em cinco pontos de coleta do complexo estuarino da Baixada Santista. 


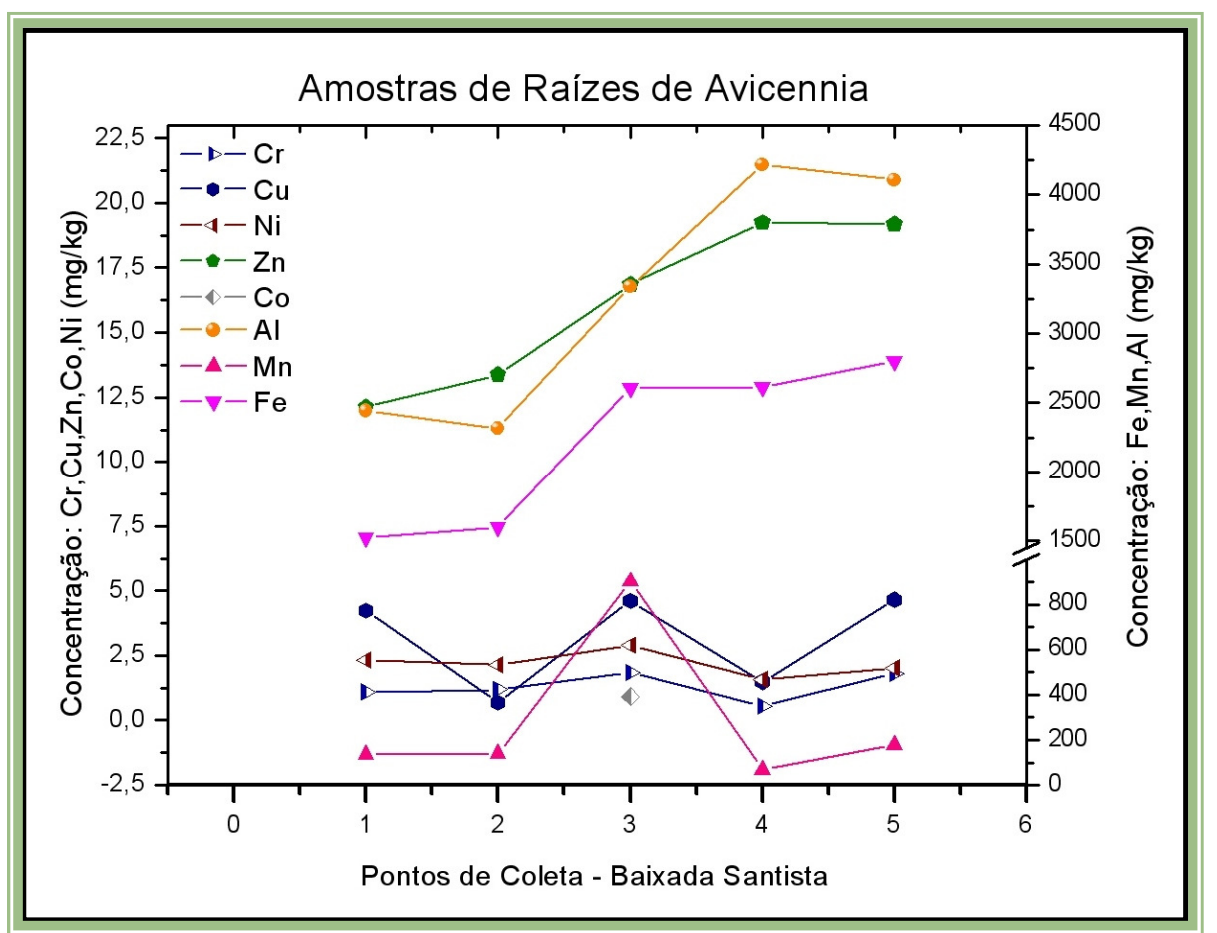

Figura 35: Gráfico de comparação das concentrações de metais pseudo-totais em amostras de raízes de Avicennia schaueriana (mangue preto) em cinco pontos de coleta do complexo estuarino da Baixada Santista.

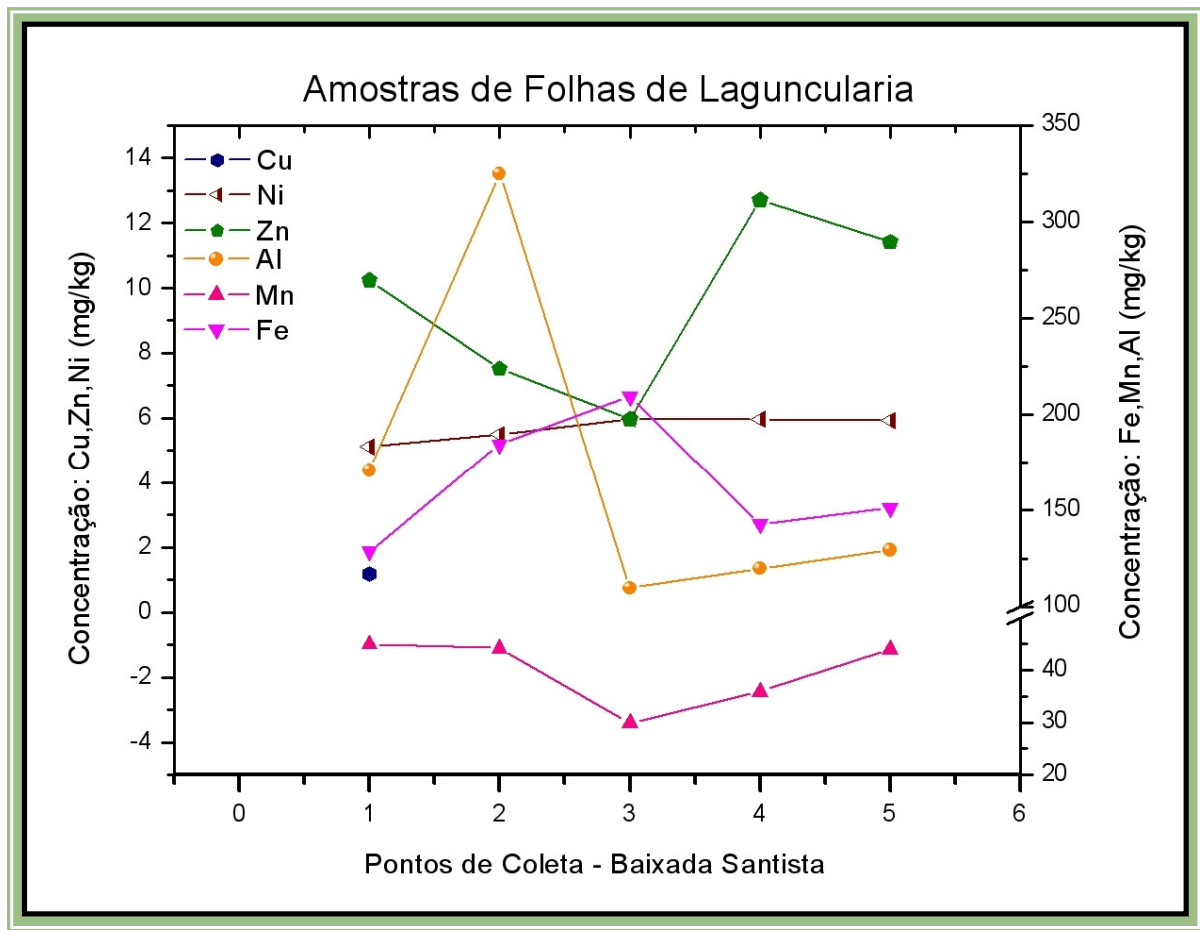

Figura 36: Gráfico de comparação das concentrações de metais pseudo-totais em amostras de folhas de Laguncularia racemosa (mangue branco) em cinco pontos de coleta do complexo estuarino da Baixada Santista. 


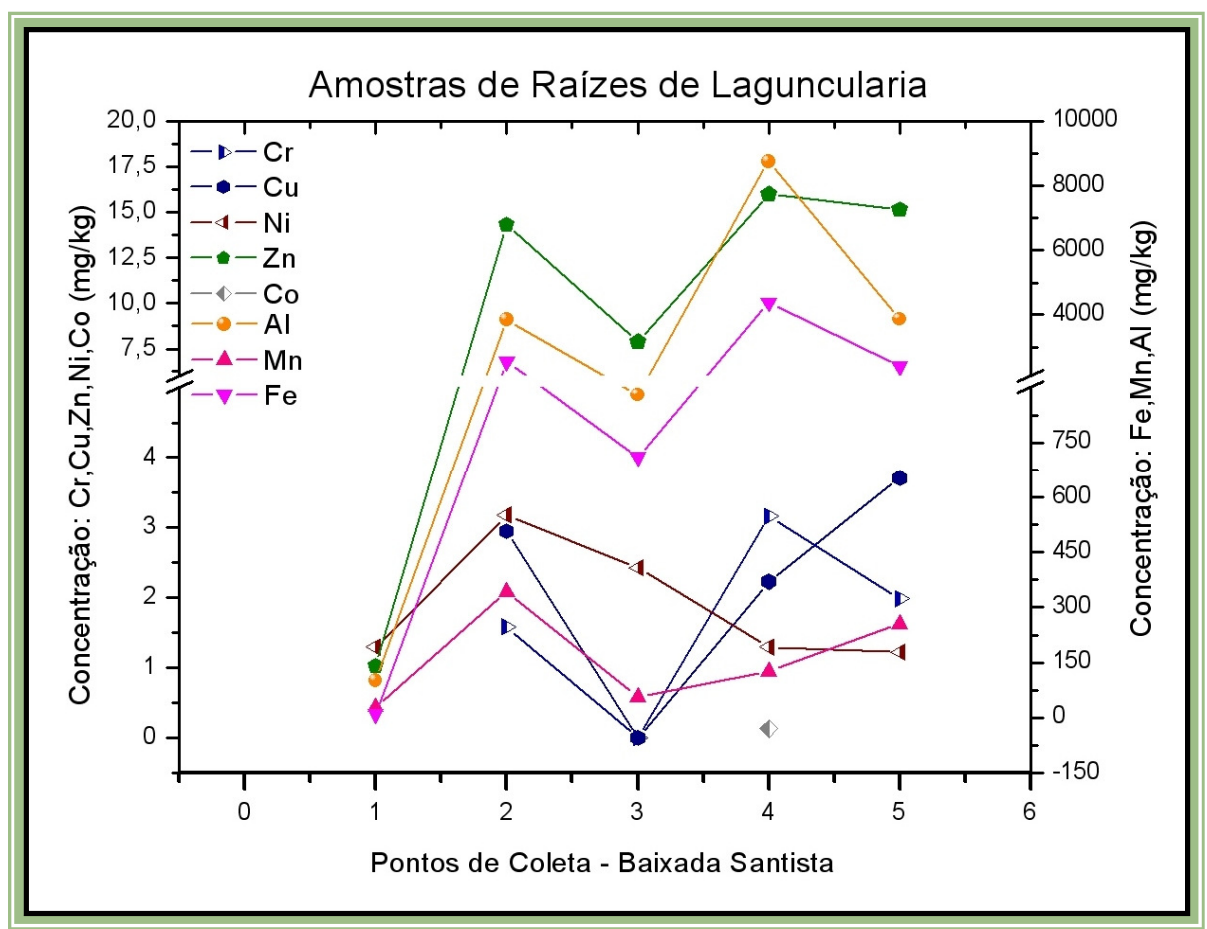

Figura 37: Gráfico de comparação das concentrações de metais pseudo-totais em amostras de raízes de Laguncularia racemosa (mangue branco) em cinco pontos de coleta do complexo estuarino da Baixada Santista.

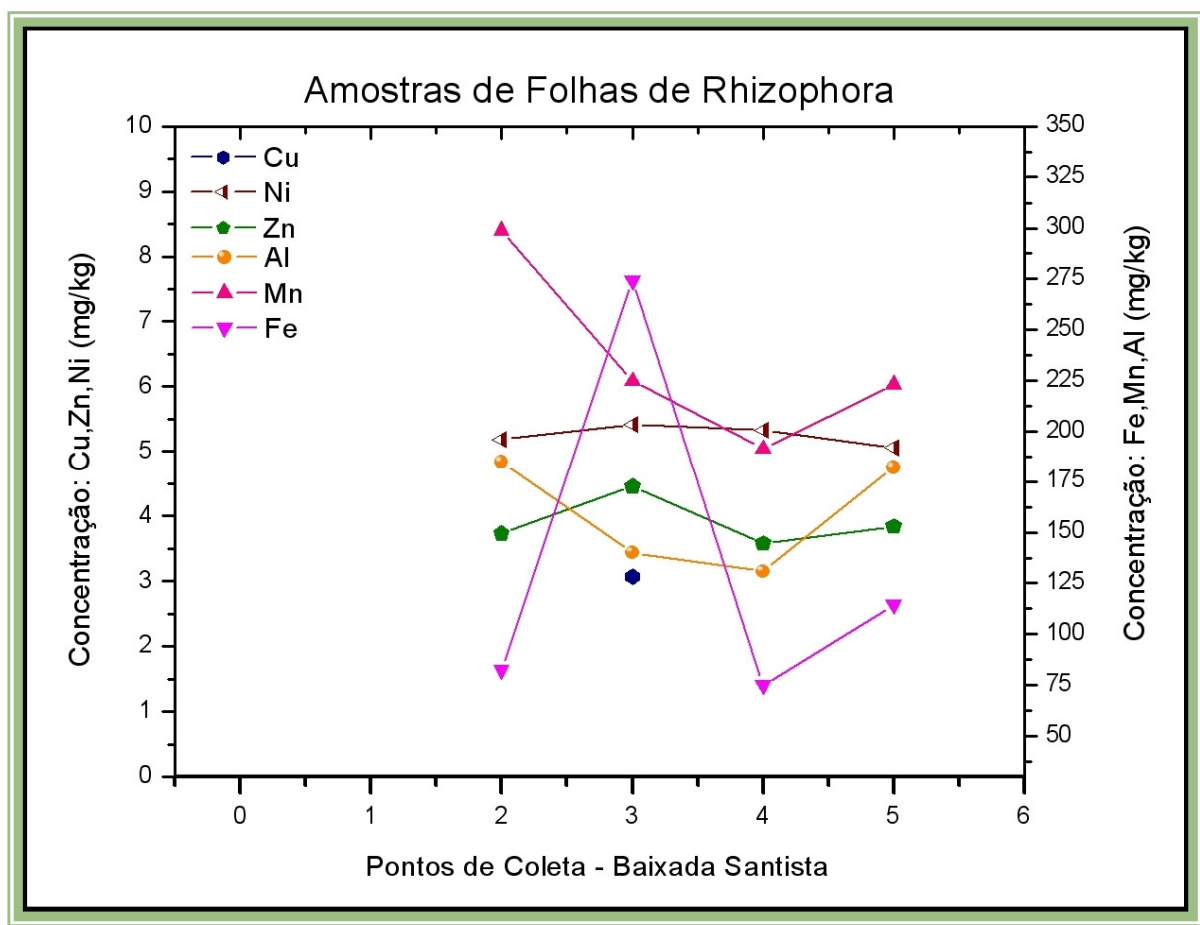

Figura 38: Gráfico de comparação das concentrações de metais pseudo-totais em amostras de folhas de Rhizophora mangle (mangue vermelho) em quatro pontos de coleta do complexo estuarino da Baixada Santista. 


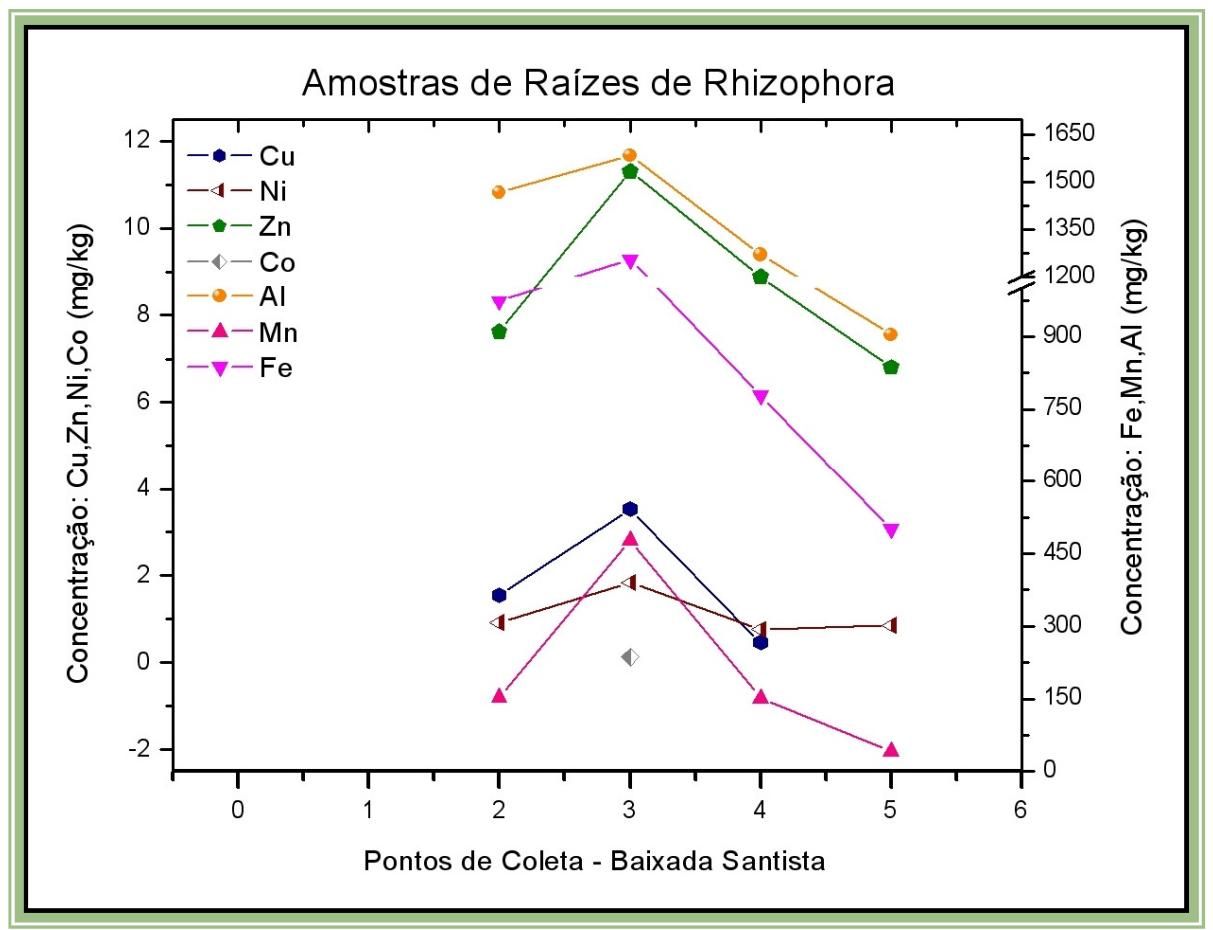

Figura 39: Gráfico de comparação das concentrações de metais pseudo-totais em amostras de raízes de Rhizophora mangle (mangue vermelho) em quatro pontos de coleta do complexo estuarino da Baixada Santista.

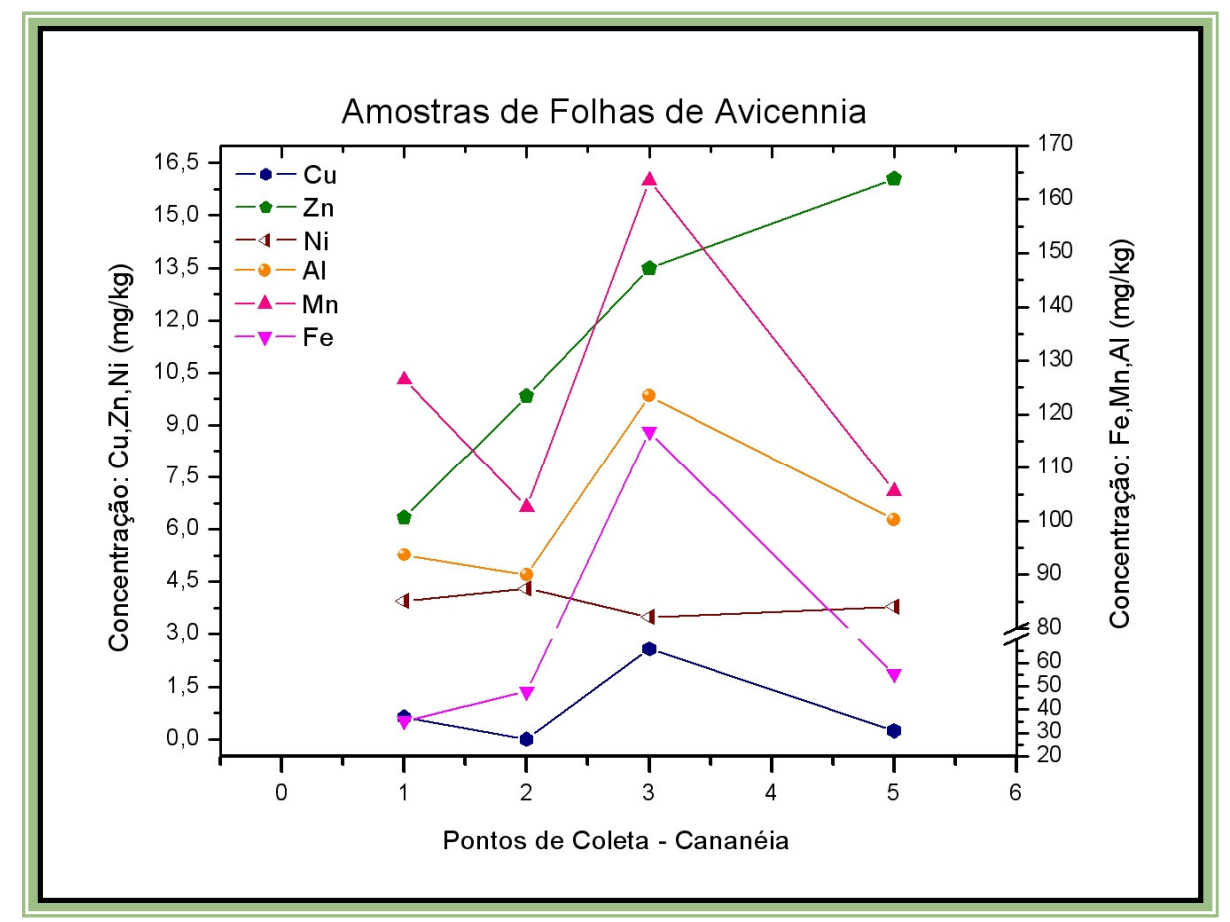

Figura 40: Gráfico de comparação das concentrações de metais pseudo-totais em amostras de folhas de Avicennia schaueriana (mangue preto) em quatro pontos de coleta do complexo estuarino de Cananéia. 


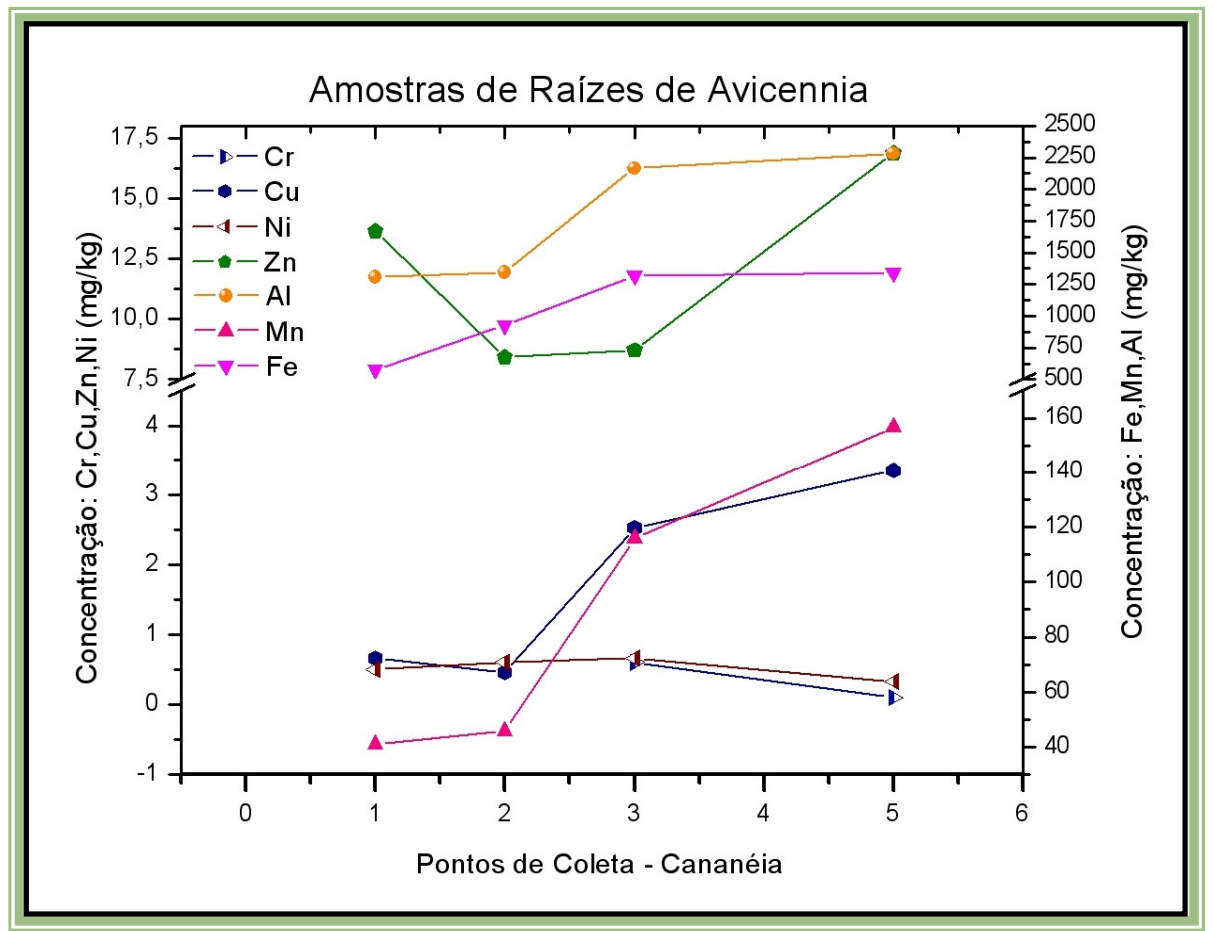

Figura 41: Gráfico de comparação das concentrações de metais pseudo-totais em amostras de raízes de Avicennia schaueriana (mangue preto) em quatro pontos de coleta do complexo estuarino de Cananéia.

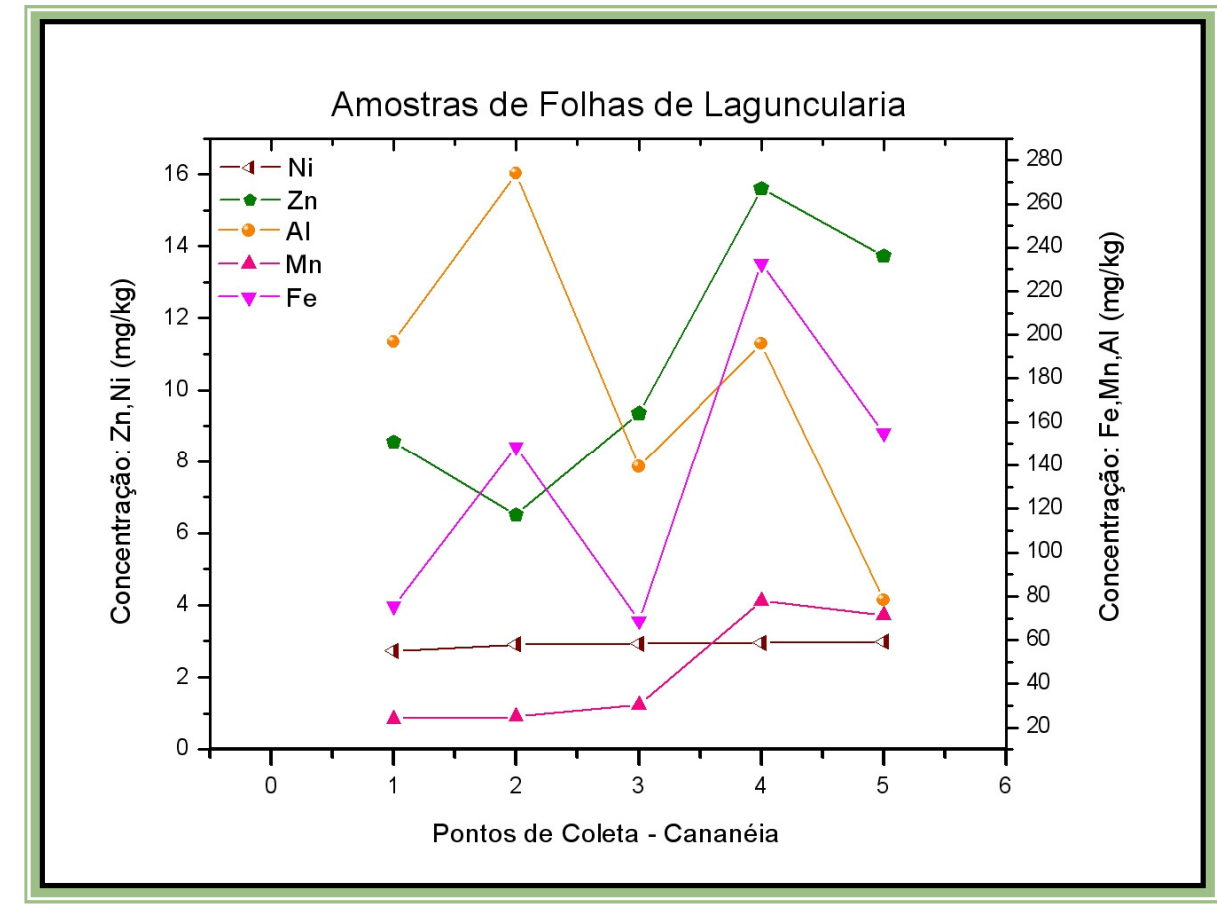

Figura 42: Gráfico de comparação das concentrações de metais pseudo-totais em amostras de folhas de Laguncularia racemosa (mangue branco) em cinco pontos de coleta do complexo estuarino de Cananéia. 


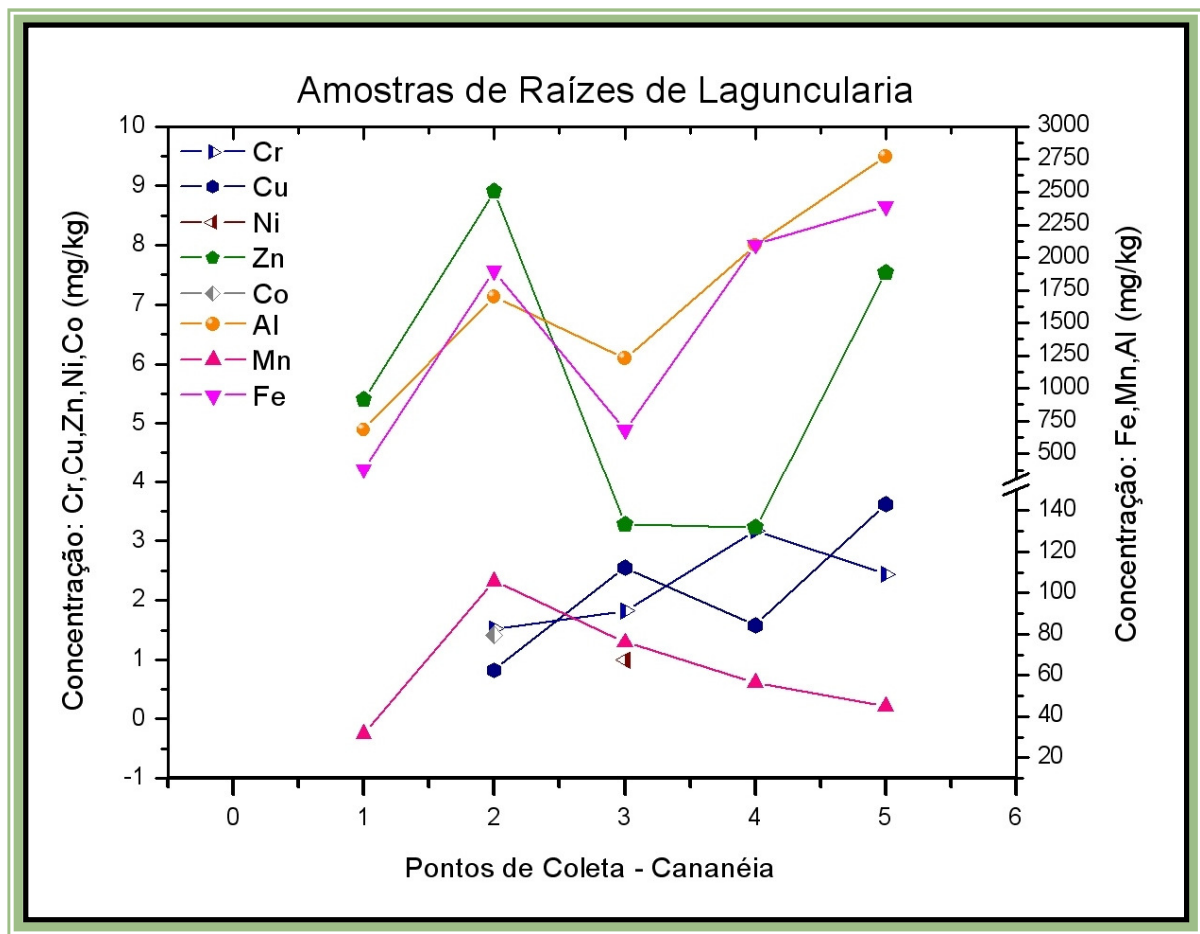

Figura 43: Gráfico de comparação das concentrações de metais pseudo-totais em amostras de raízes de Laguncularia racemosa (mangue branco) em cinco pontos de coleta do complexo estuarino de Cananéia.

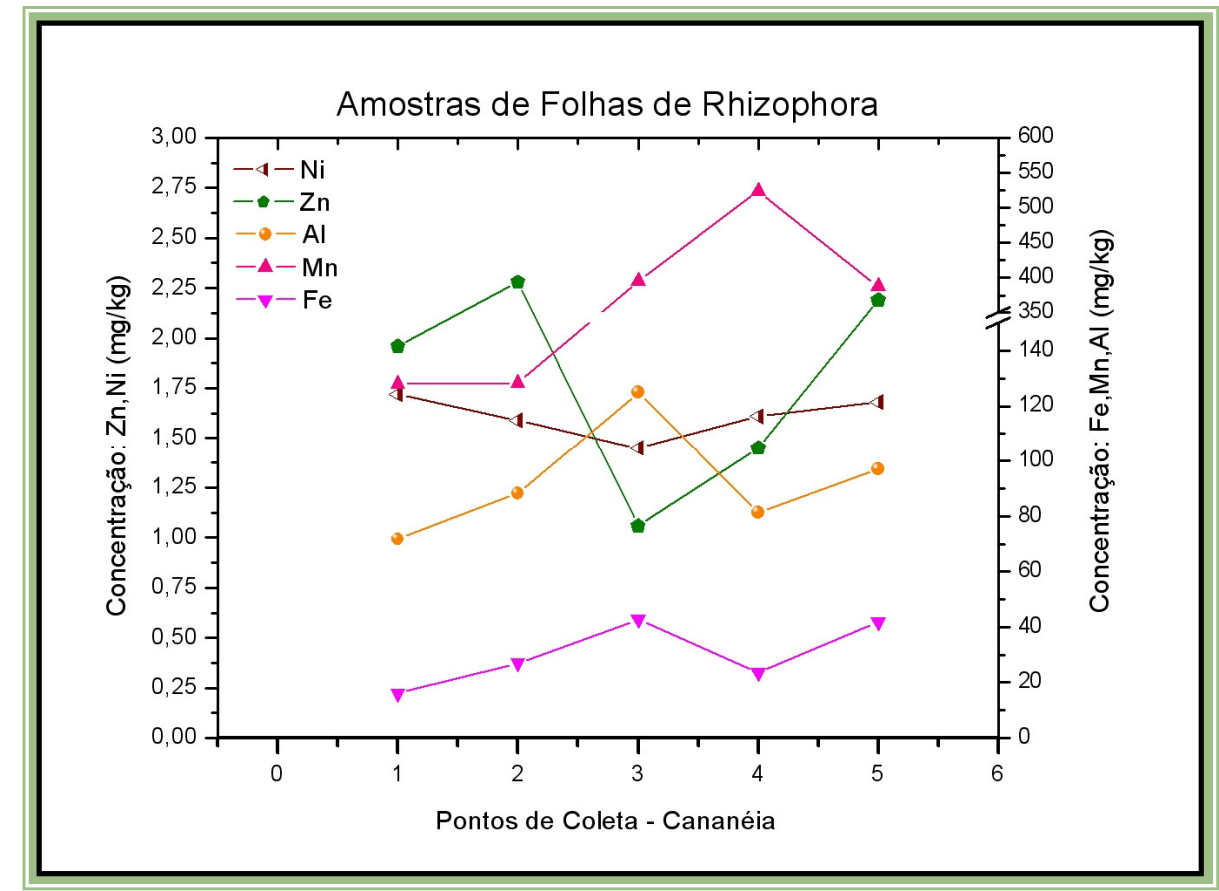

Figura 44: Gráfico de comparação das concentrações de metais pseudo-totais em amostras de folhas de Rhizophora mangle (mangue vermelho) em cinco pontos de coleta do complexo estuarino de Cananéia. 


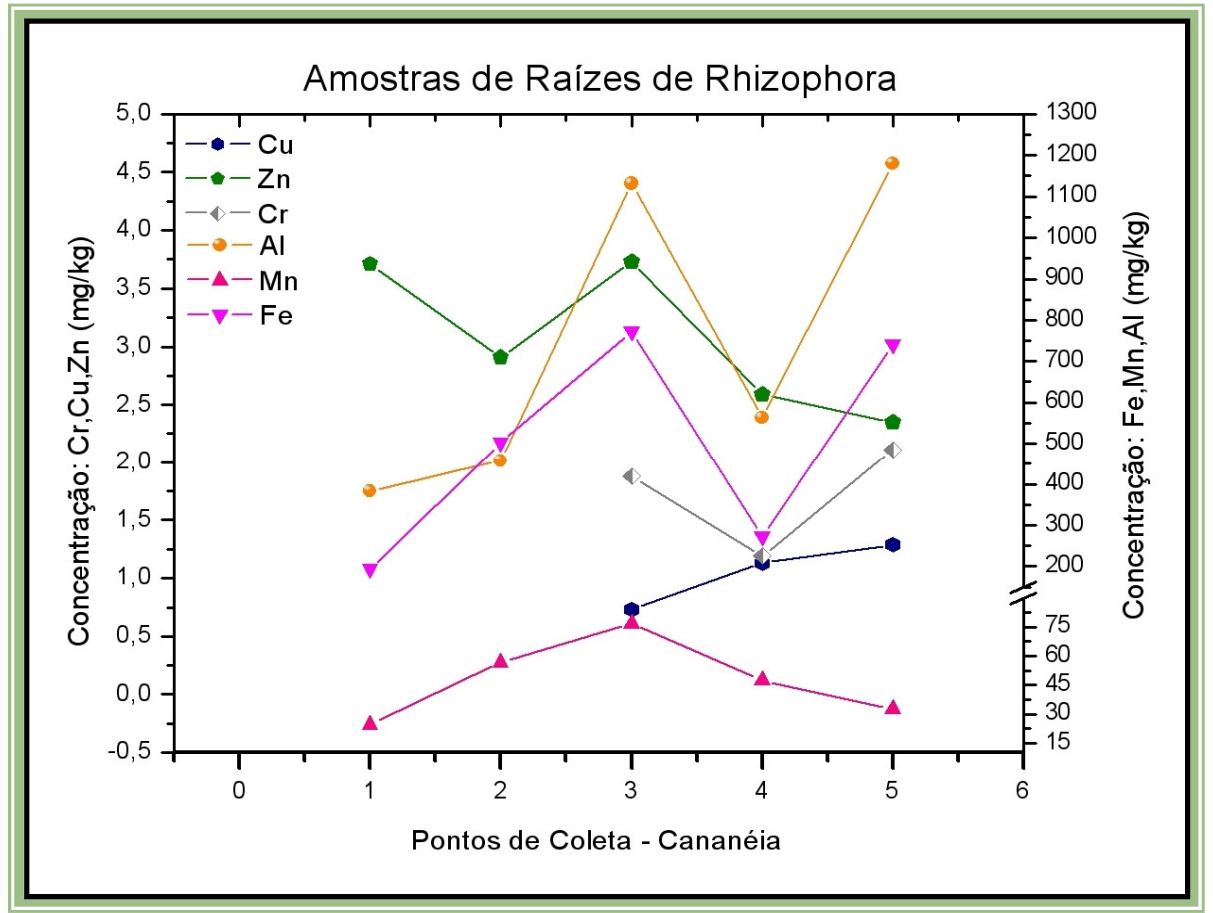

Figura 45: Gráfico de comparação das concentrações de metais pseudo-totais em amostras de raízes de Rhizophora mangle (mangue vermelho) em cinco pontos de coleta do complexo estuarino de Cananéia.

Ainda na discussão dos resultados para a análise de metais, o passo seguinte deste trabalho foi relacionar os resultados obtidos em diferentes matrizes num só ponto de coleta. Desta maneira, iniciando no ponto 1 da Baixada Santista, foi possível observar através dos gráficos apresentados nas figuras $46 \mathrm{a}$ e $46 \mathrm{~b}$ que, de uma maneira geral, os metais se concentram no sedimento. $\mathrm{Na}$ figura $46 \mathrm{a}$ se observa que há mais $\mathrm{Cr}$ e $\mathrm{Pb}$ do que $\mathrm{Co}$ e $\mathrm{Cu}$ presentes, apesar disto, as amostras de folhas e raízes de mangue apresentam maior concentração de $\mathrm{Cu}$ ao invés de $\mathrm{Pb}$ por exemplo.

Fazendo a mesma comparação no ponto 2 de coleta (figura 47a), foi possível observar semelhança em relação ao sedimento, entretanto, nas folhas da espécie Avicennia schaueriana há maior concentração de $\mathrm{Cr}$ e $\mathrm{Pb}$ em contraste com o $\mathrm{Co}$ e o $\mathrm{Cu}$, acompanhando o sedimento. Desta forma, a disponibilidade de diferentes metais para estas espécies de mangue pode acarretar em uma troca de nutrientes por compostos potencialmente tóxicos. $\mathrm{O}$ mesmo raciocínio segue para os outros pontos de coleta mostrados em seguida. 
Ao estudar os gráficos apresentados nas figuras $46 \mathrm{~b}$ e $47 \mathrm{~b}$, pode-se deduzir que, em geral, as plantas seguem uma correlação entre os metais $\mathrm{Mn}$, Fe e Al similar ao sedimento.

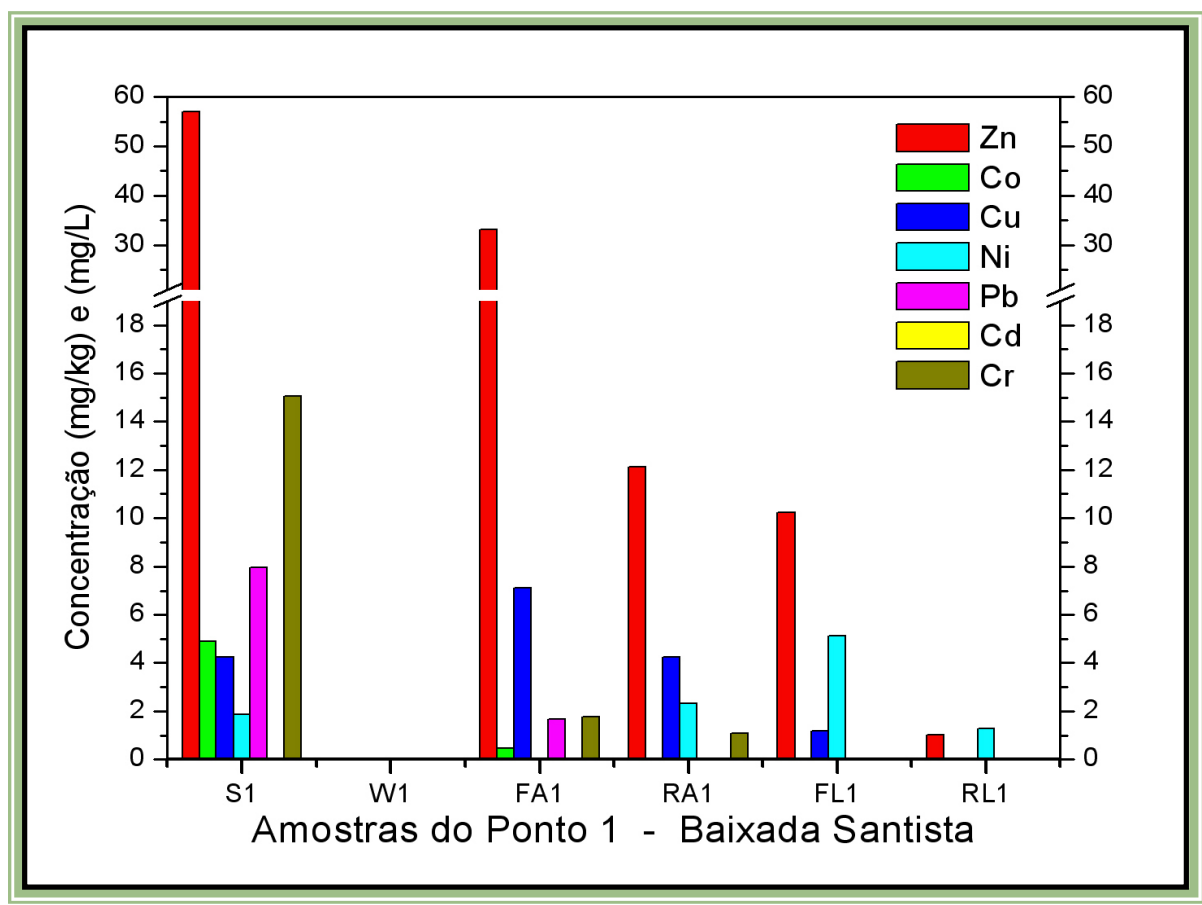

Figura 46a: Gráfico de comparação das concentrações de metais pseudo-totais em diferentes matrizes do ponto 1 do complexo estuarino da Baixada Santista.

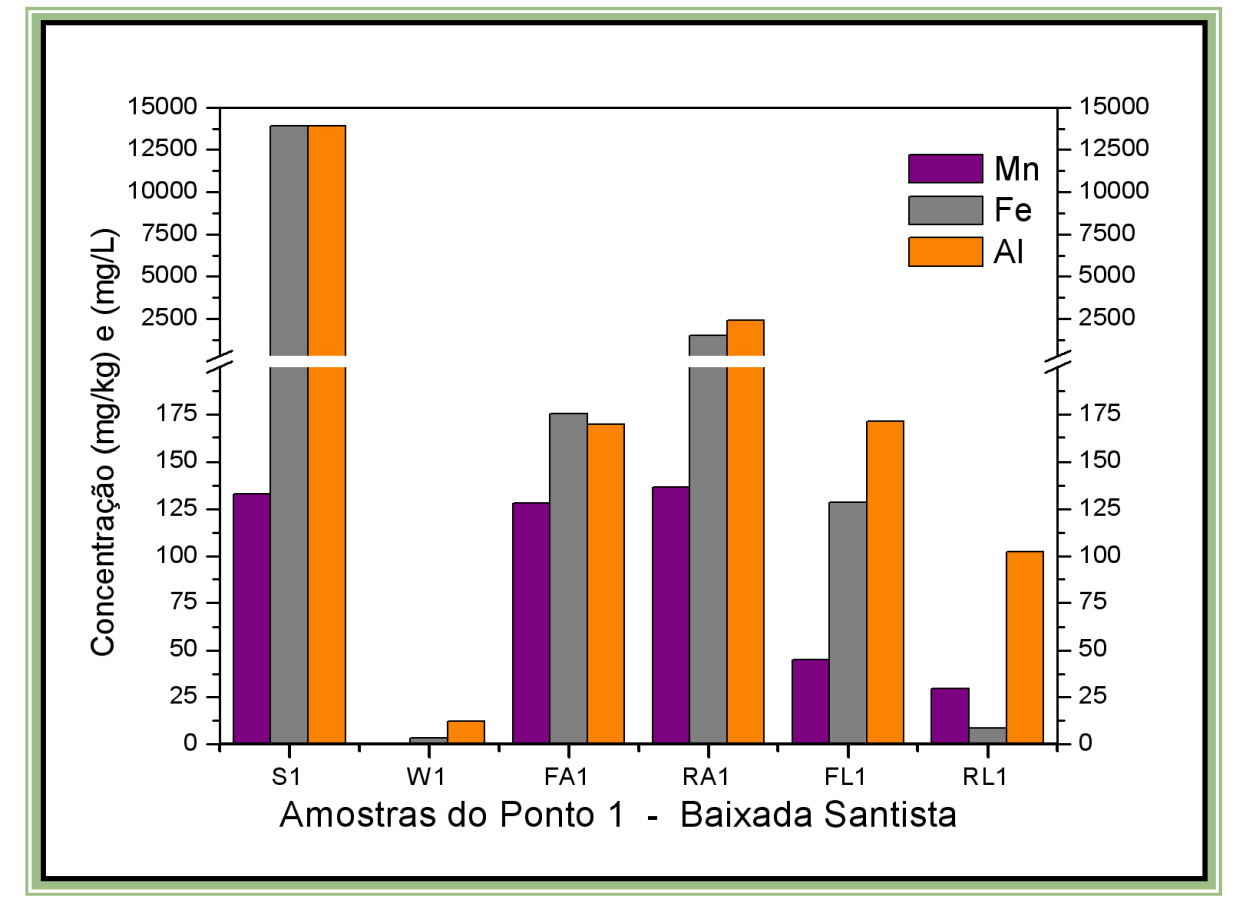

Figura 46b: Gráfico de comparação das concentrações de metais pseudo-totais em diferentes matrizes do ponto 1 do complexo estuarino da Baixada Santista. 
Nos diferentes pontos de coleta da Baixada Santista, foi possível observar um comportamento similar para o Zn presente nas folhas e raízes de mangues, bem como para o $\mathrm{Ni}$. Na relação folha-raiz da espécie Avicennia shaueriana observa-se que o Zn está mais presente nas folhas, o contrário do que ocorre com as espécies Laguncularia racemosa e Rhizophora mangle, que apresentam maior quantidade deste metal nas raízes. No caso do $\mathrm{Ni}$, este nem aparece nas folhas de Avicennia, marcando presença apenas em suas raízes, porém para as espécies Laguncularia e Rhizophora, o Ni se mostra em maior quantidade nas folhas do que nas raízes. Desta forma, estas características podem ser um indicativo que para alguns metais, independente da disponibilidade no sedimento, as plantas de mangue podem apresentar preferências.

Outra observação curiosa é o comportamento do Mn nas folhas de Rhizophora, que apresenta maior quantidade do que o esperado nos pontos 2 (figura 47b), 4 (figura 49b) e 5 (figura 50b), se considerarmos o comportamento deste metal em relação ao Al e Fe nas amostras de sedimento.

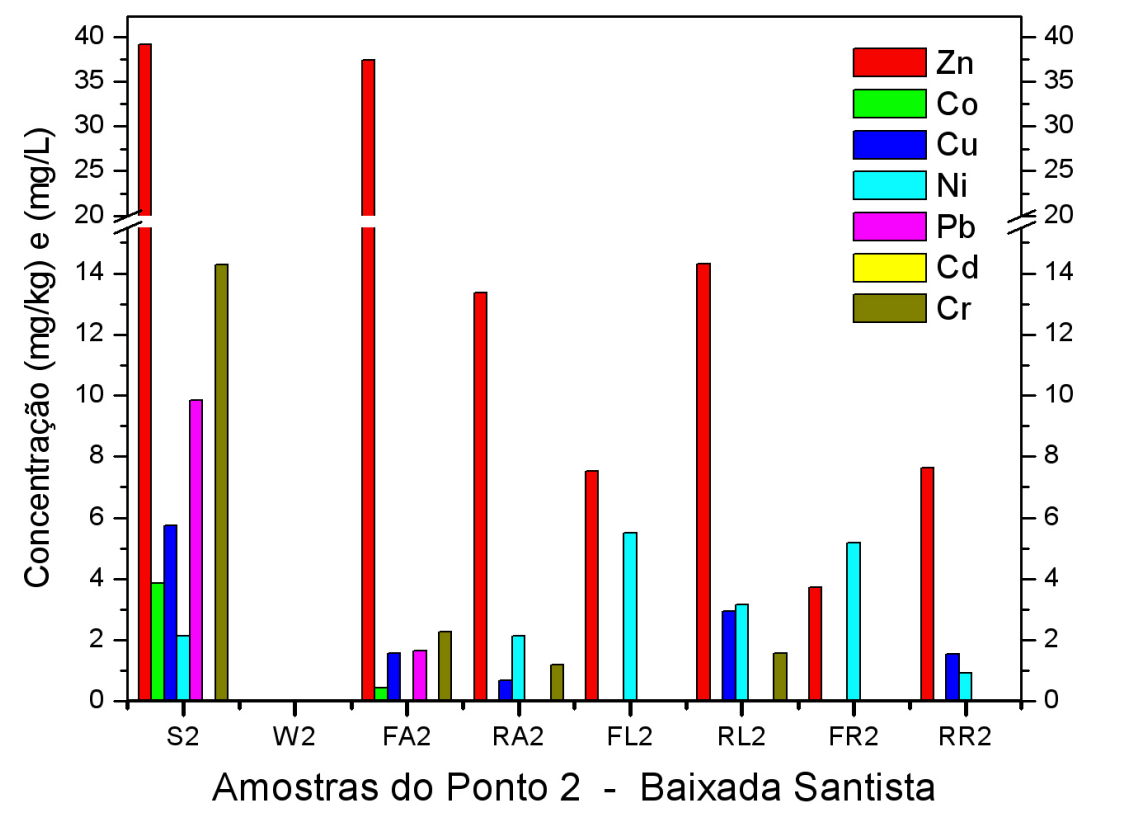

Figura 47a: Gráfico de comparação das concentrações de metais pseudo-totais em diferentes matrizes do ponto 2 do complexo estuarino da Baixada Santista. 


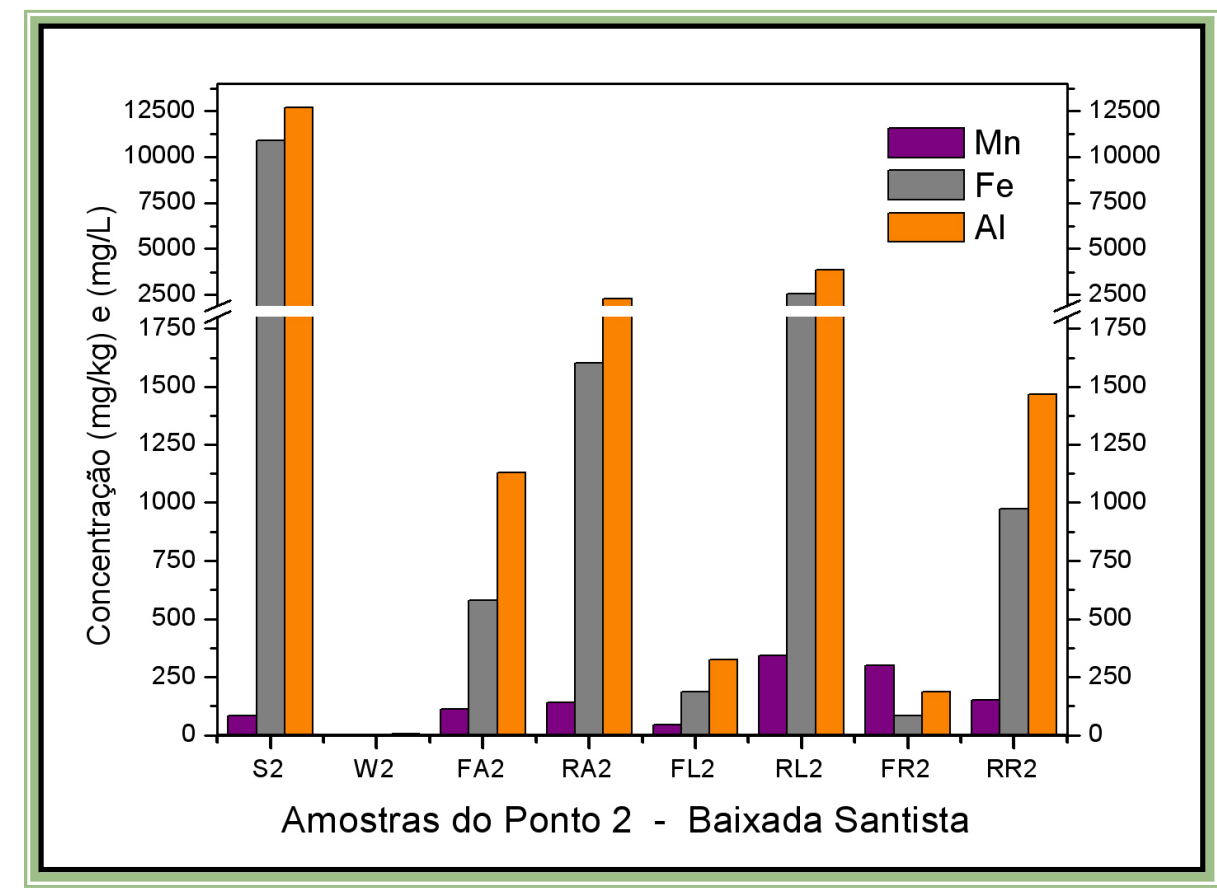

Figura 47b: Gráfico de comparação das concentrações de metais pseudo-totais em diferentes matrizes do ponto 2 do complexo estuarino da Baixada Santista.

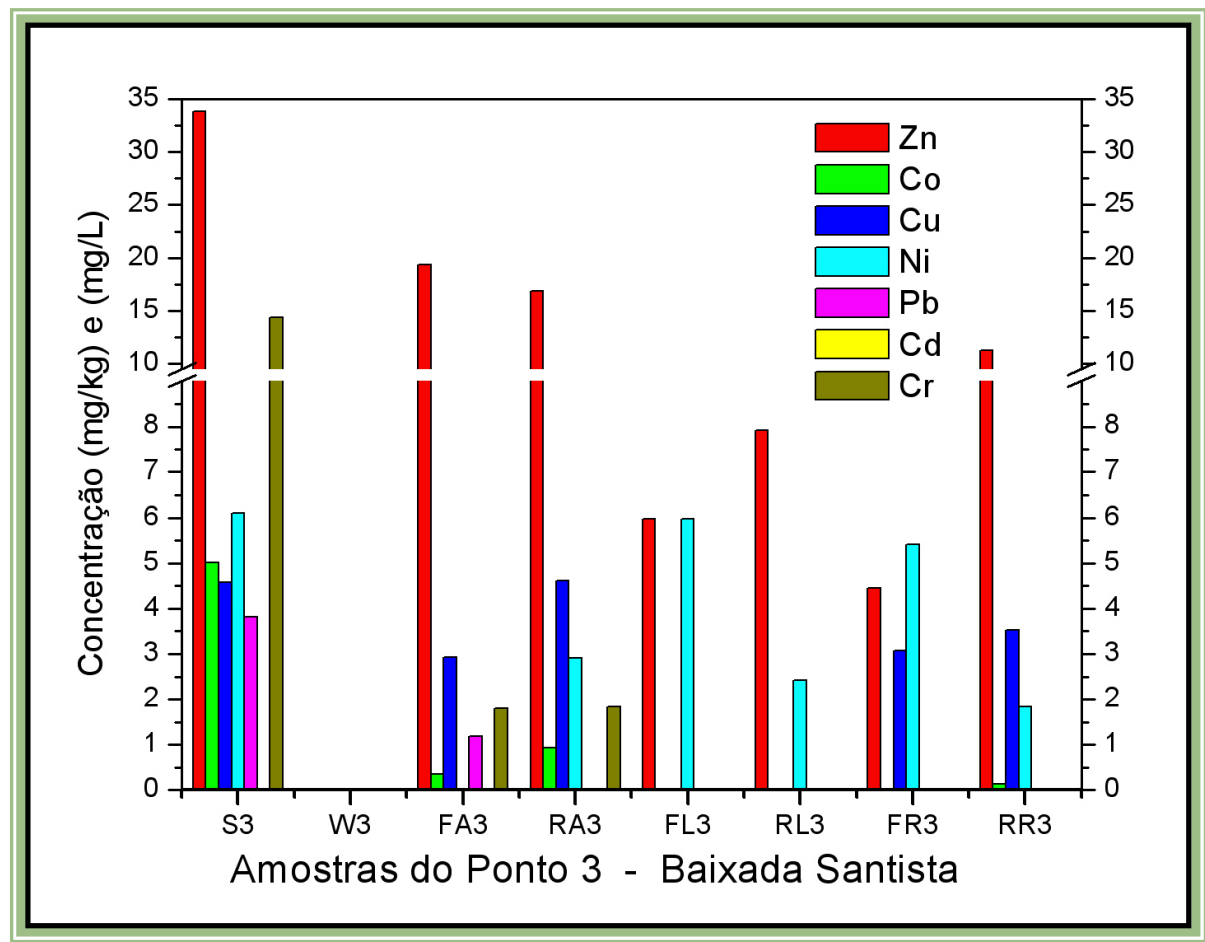

Figura 48a: Gráfico de comparação das concentrações de metais pseudo-totais em diferentes matrizes do ponto 3 do complexo estuarino da Baixada Santista. 


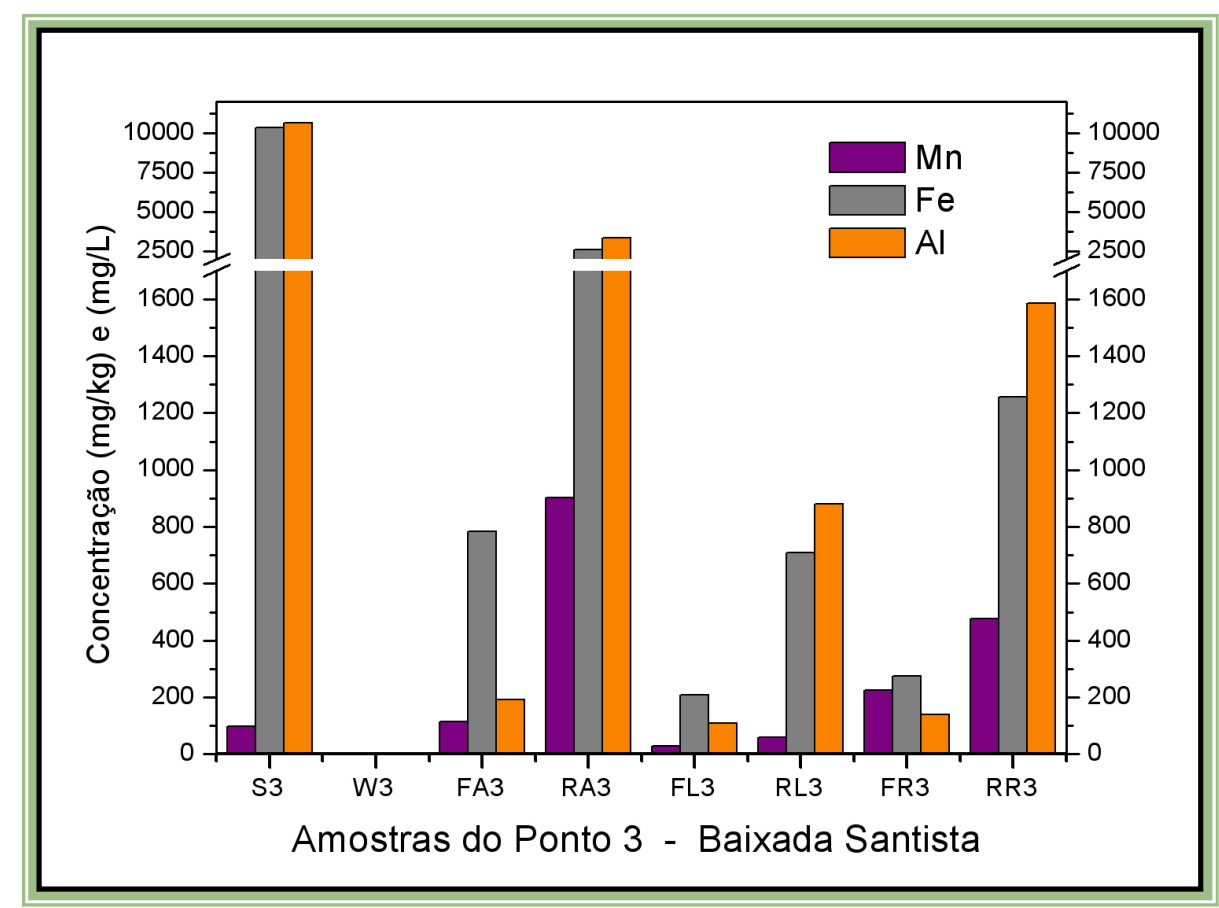

Figura 48b: Gráfico de comparação das concentrações de metais pseudo-totais em diferentes matrizes do ponto 3 do complexo estuarino da Baixada Santista.

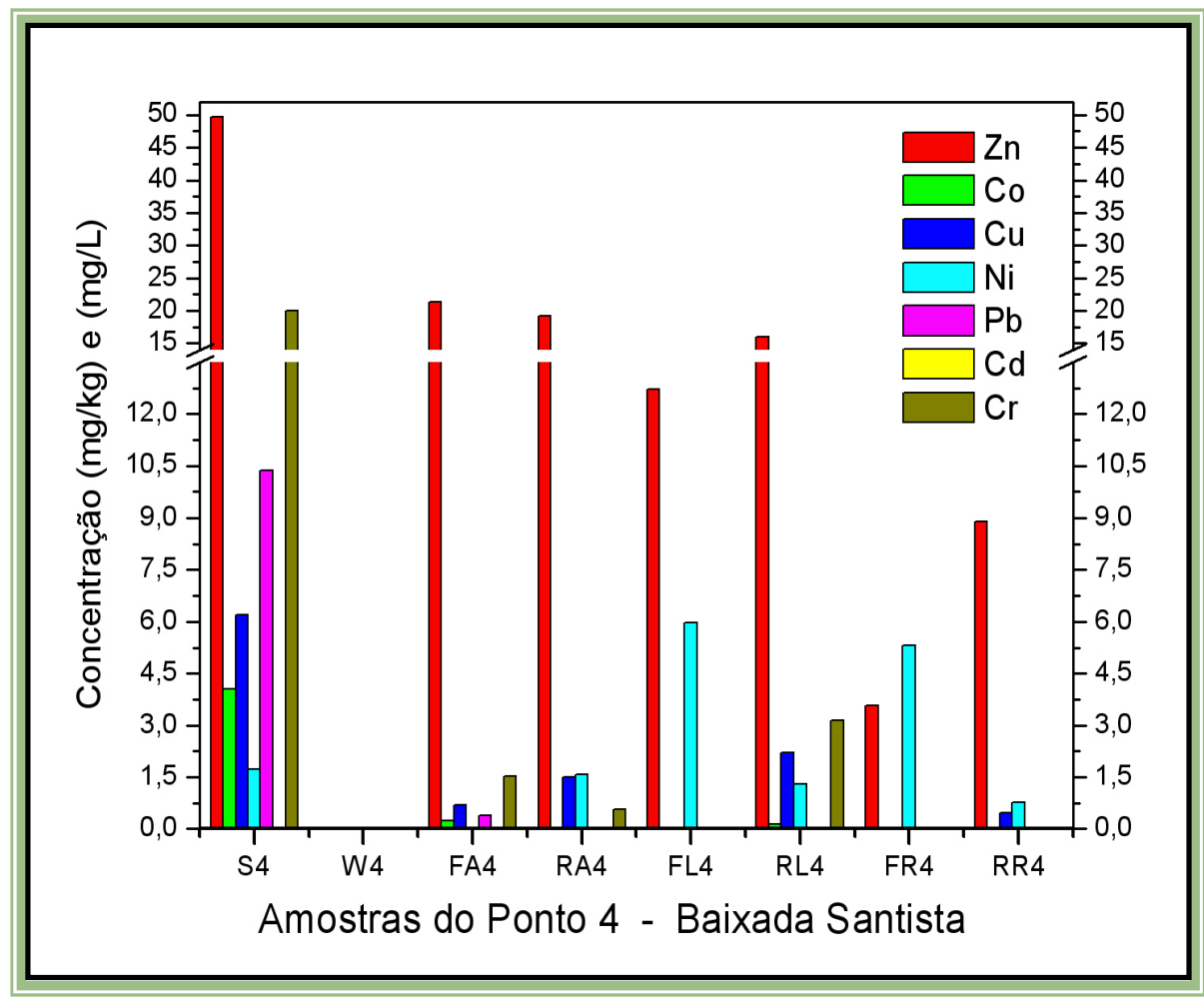

Figura 49a: Gráfico de comparação das concentrações de metais pseudo-totais em diferentes matrizes do ponto 4 do complexo estuarino da Baixada Santista. 


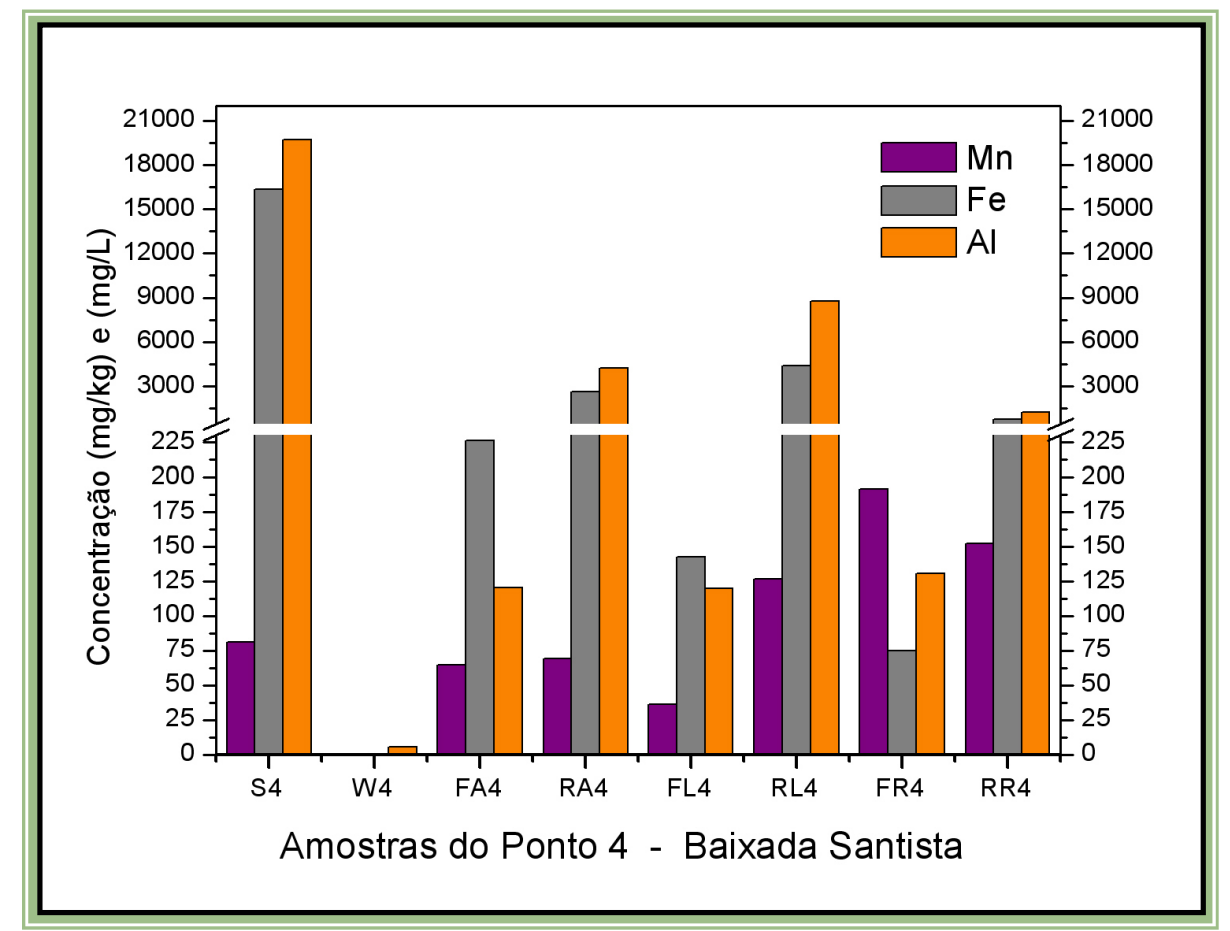

Figura 49b: Gráfico de comparação das concentrações de metais pseudo-totais em diferentes matrizes do ponto 4 do complexo estuarino da Baixada Santista.

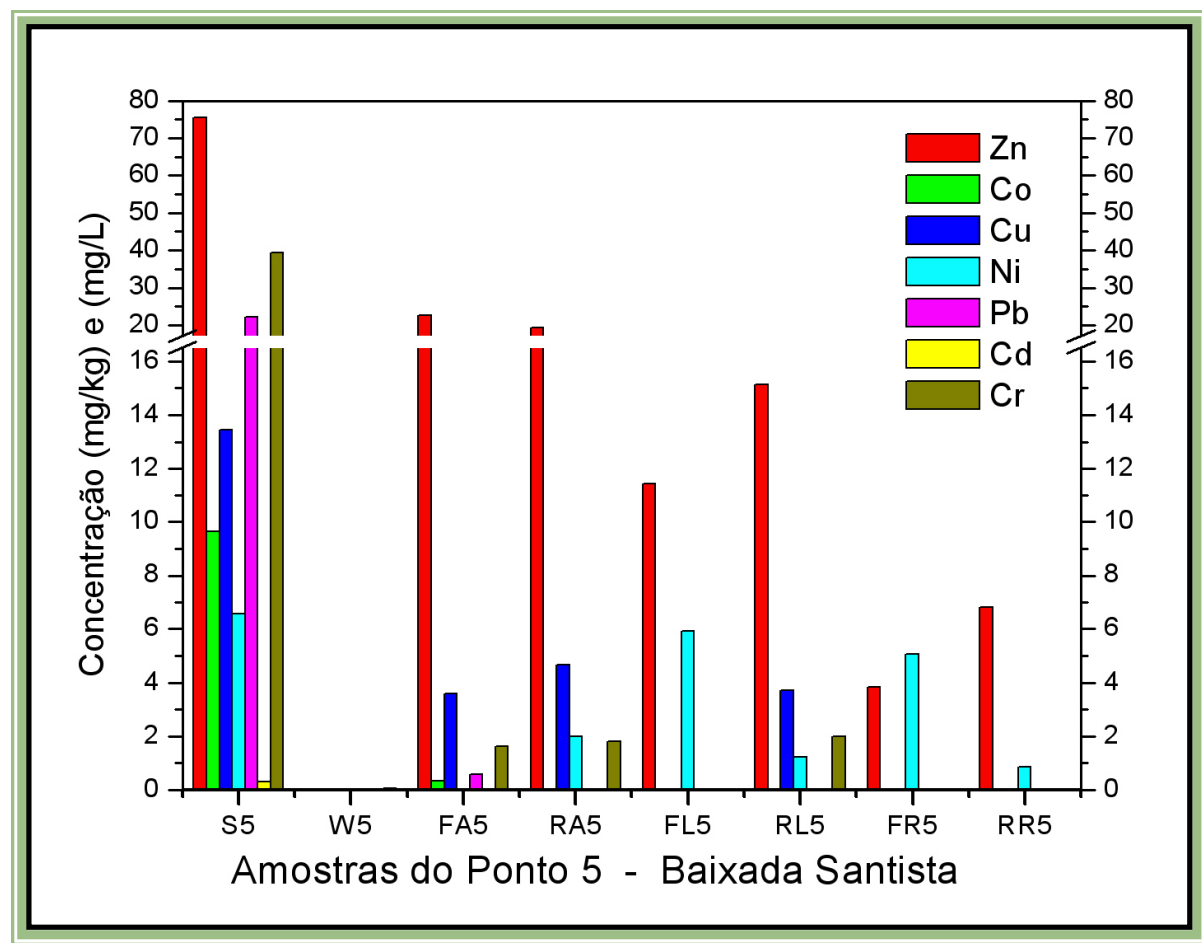

Figura 50a: Gráfico de comparação das concentrações de metais pseudo-totais em diferentes matrizes do ponto 5 do complexo estuarino da Baixada Santista. 


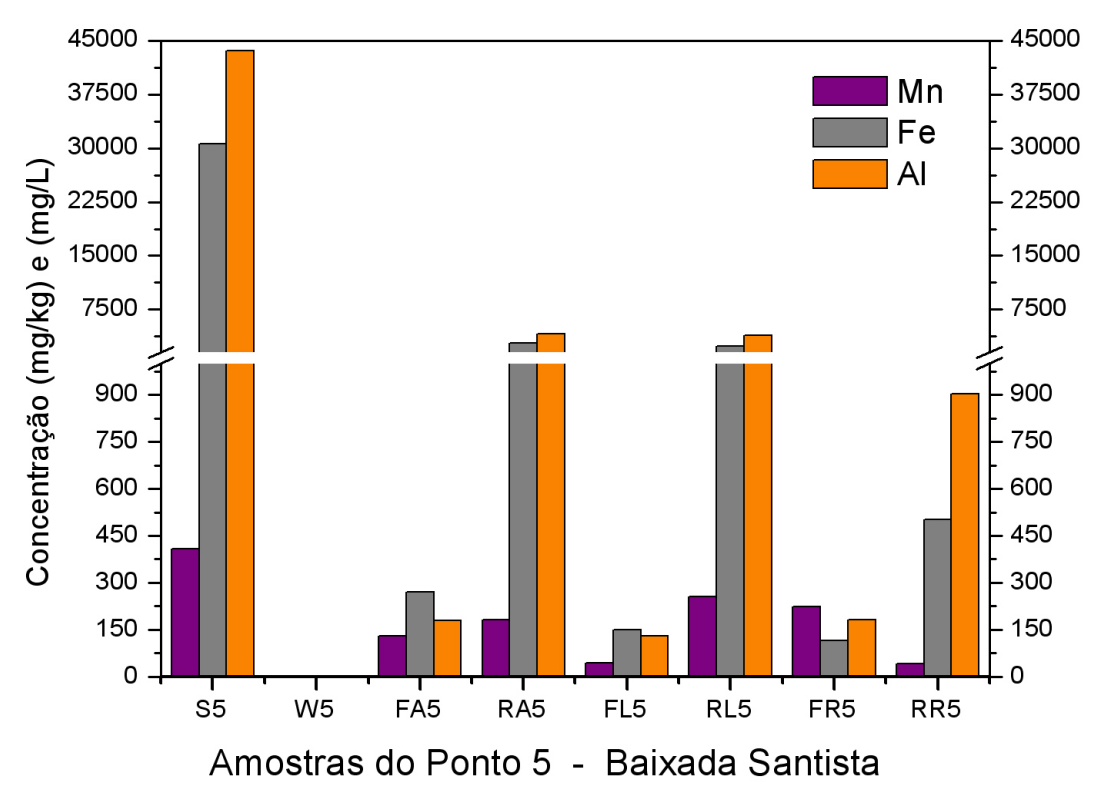

Figura 50b: Gráfico de comparação das concentrações de metais pseudo-totais em diferentes matrizes do ponto 5 do complexo estuarino da Baixada Santista.

Assim como para região da Baixada Santista, no complexo estuarino de Cananéia a presença de $\mathrm{Pb}$ e $\mathrm{Cr}$ é mais marcante do que o Co e o $\mathrm{Cu}$ nas amostras de sedimento. No entanto, não foi observado a presença de $\mathrm{Pb}$ nas amostras de folhas e raízes de mangue, enquanto o $\mathrm{Cr}$, apesar de aparecer em algumas amostras, não segue a mesma regra que sedimentos.

O metal $\mathrm{Ni}$ que se mostrou ausente nas folhas de Avicennia nas amostras da Baixada Santista, agora marca presença nestas matrizes na região de Cananéia, além do metal Zn que não segue a mesma correlação feita para as amostras da Baixada Santista. O metal Mn se mostrou em destaque nas amostras de folhas de Avicennia e de Rhizophora, observações estas que podem ser feitas através das figuras 51 a 55 . 


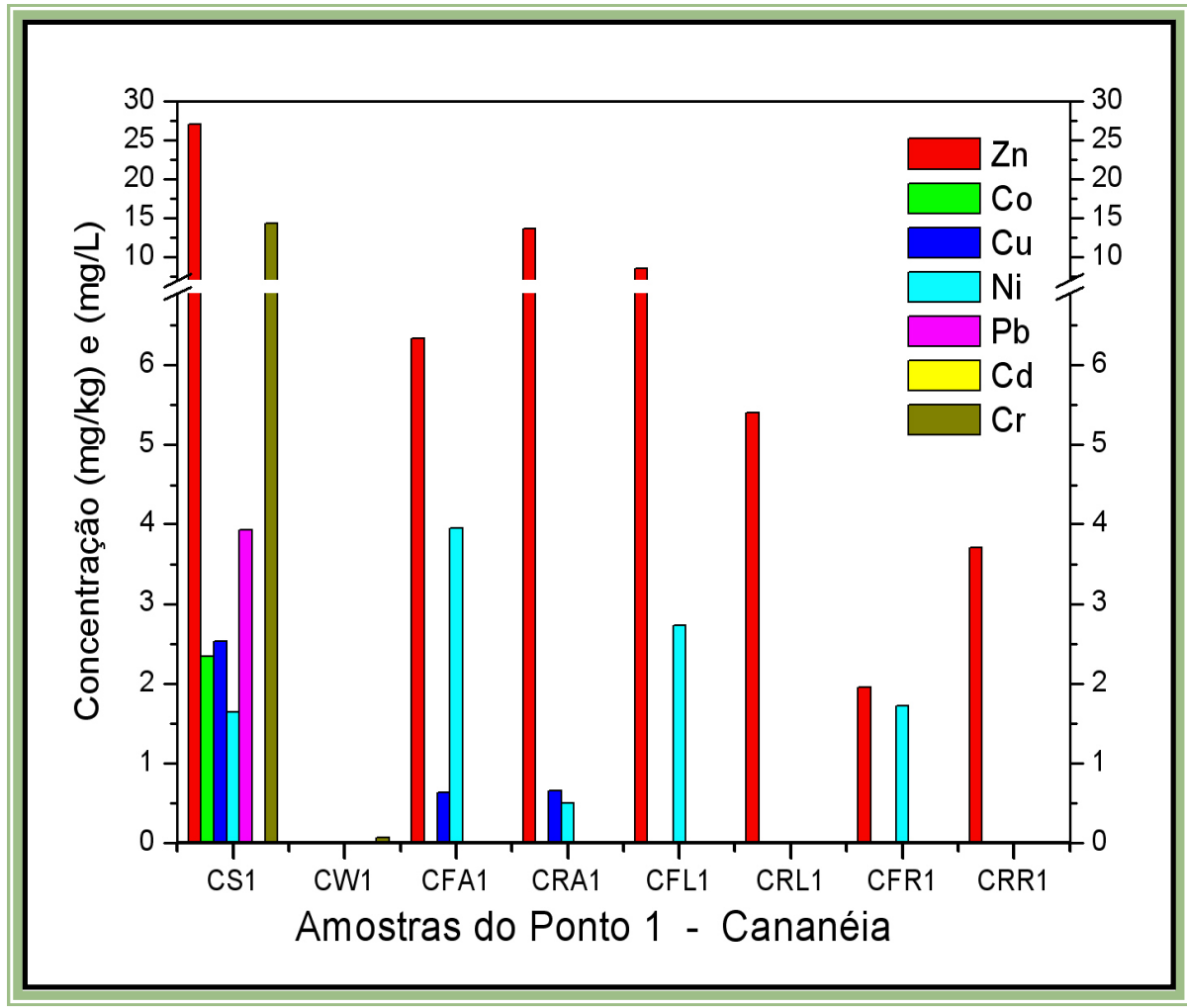

Figura 51a: Gráfico de comparação das concentrações de metais pseudo-totais em diferentes matrizes do ponto 1 do complexo estuarino de Cananéia.

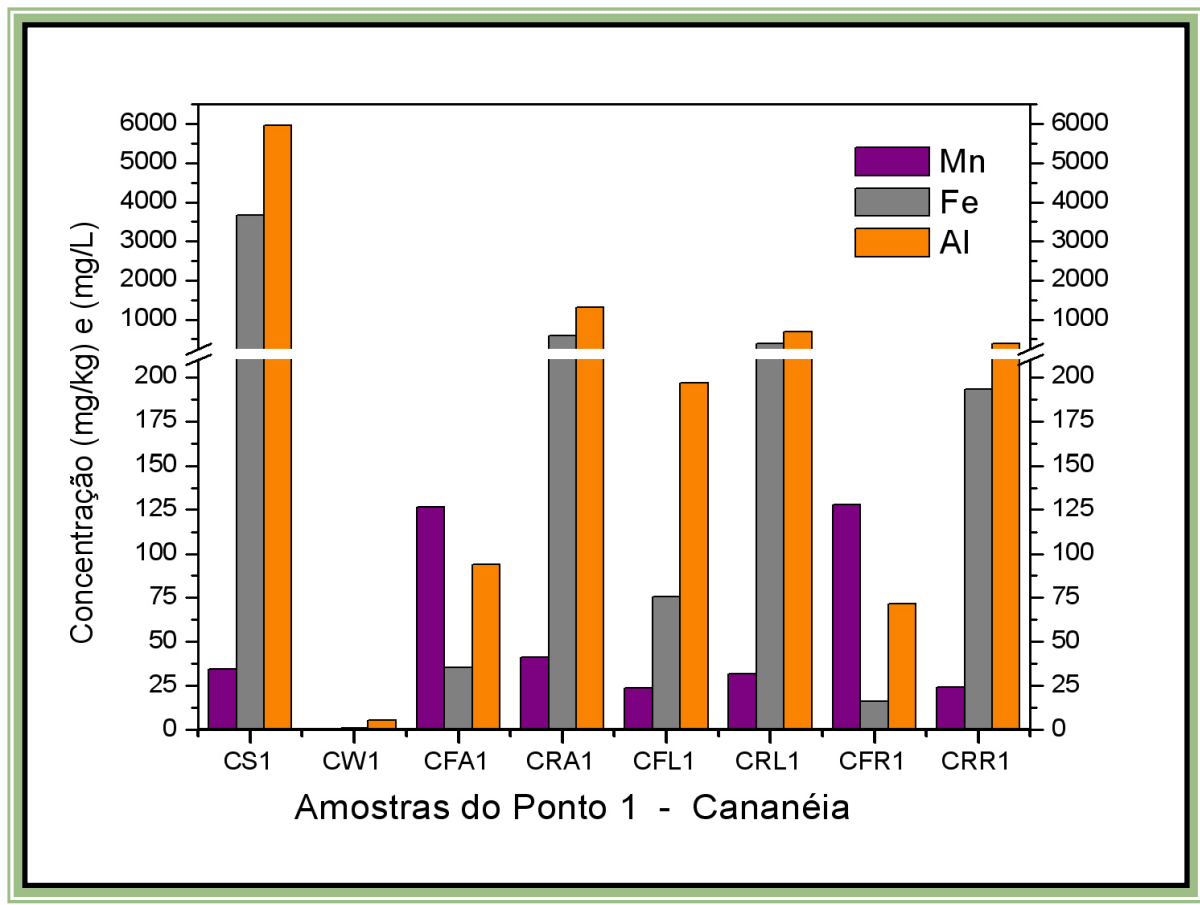

Figura 51b: Gráfico de comparação das concentrações de metais pseudo-totais em diferentes matrizes do ponto 1 do complexo estuarino de Cananéia. 


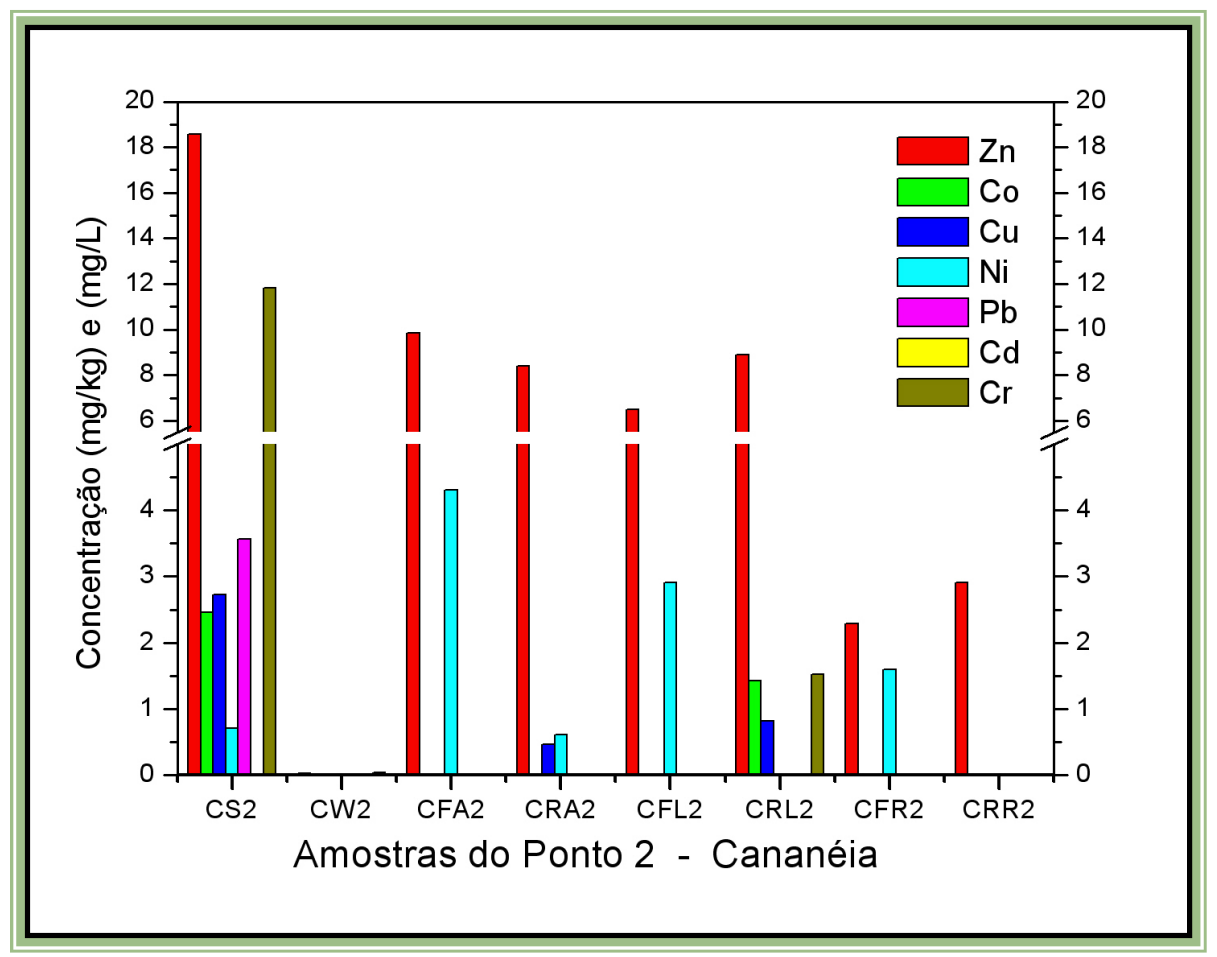

Figura 52a: Gráfico de comparação das concentrações de metais pseudo-totais em diferentes matrizes do ponto 2 do complexo estuarino de Cananéia.

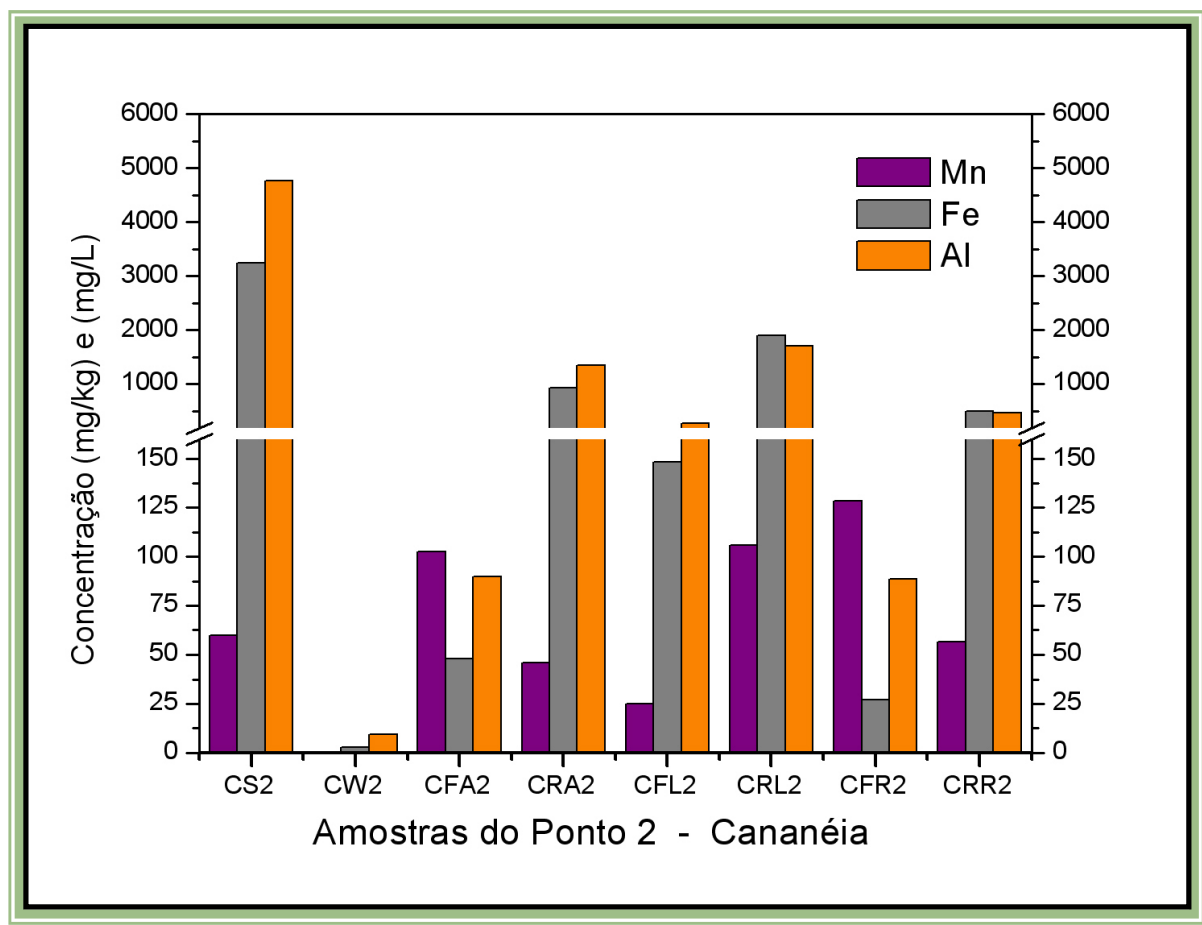

Figura 52b: Gráfico de comparação das concentrações de metais pseudo-totais em diferentes matrizes do ponto 2 do complexo estuarino de Cananéia. 


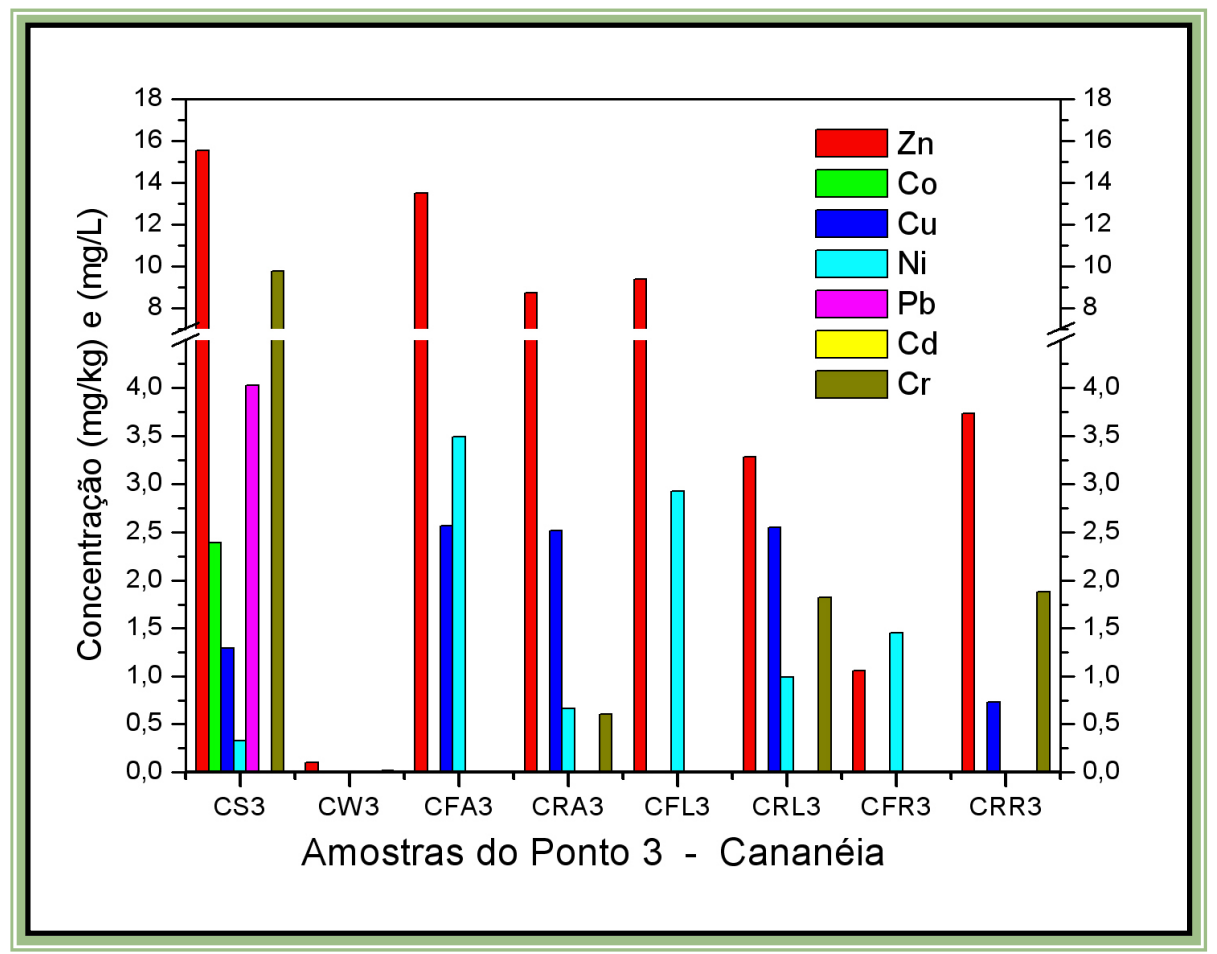

Figura 53a: Gráfico de comparação das concentrações de metais pseudo-totais em diferentes matrizes do ponto 3 do complexo estuarino de Cananéia.

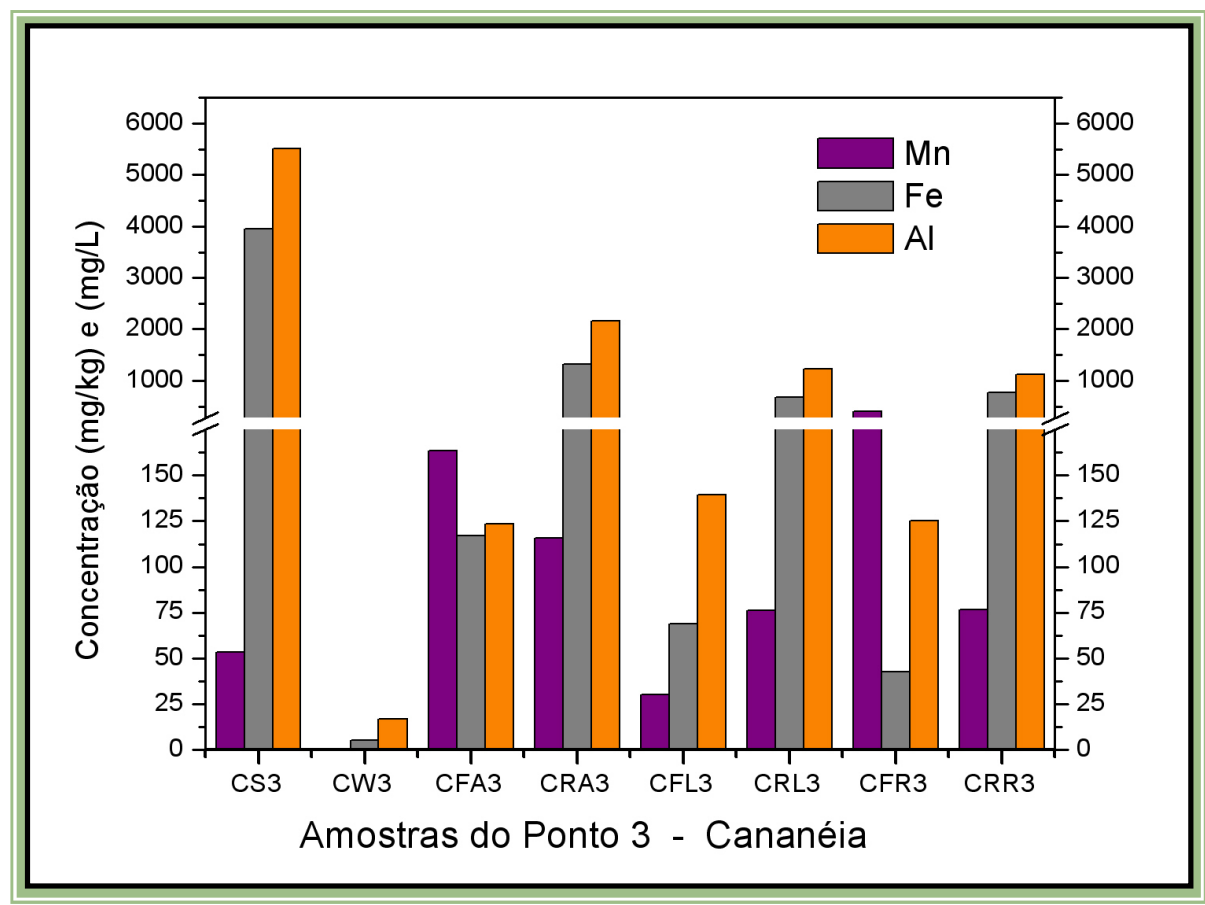

Figura 53b: Gráfico de comparação das concentrações de metais pseudo-totais em diferentes matrizes do ponto 3 do complexo estuarino de Cananéia. 


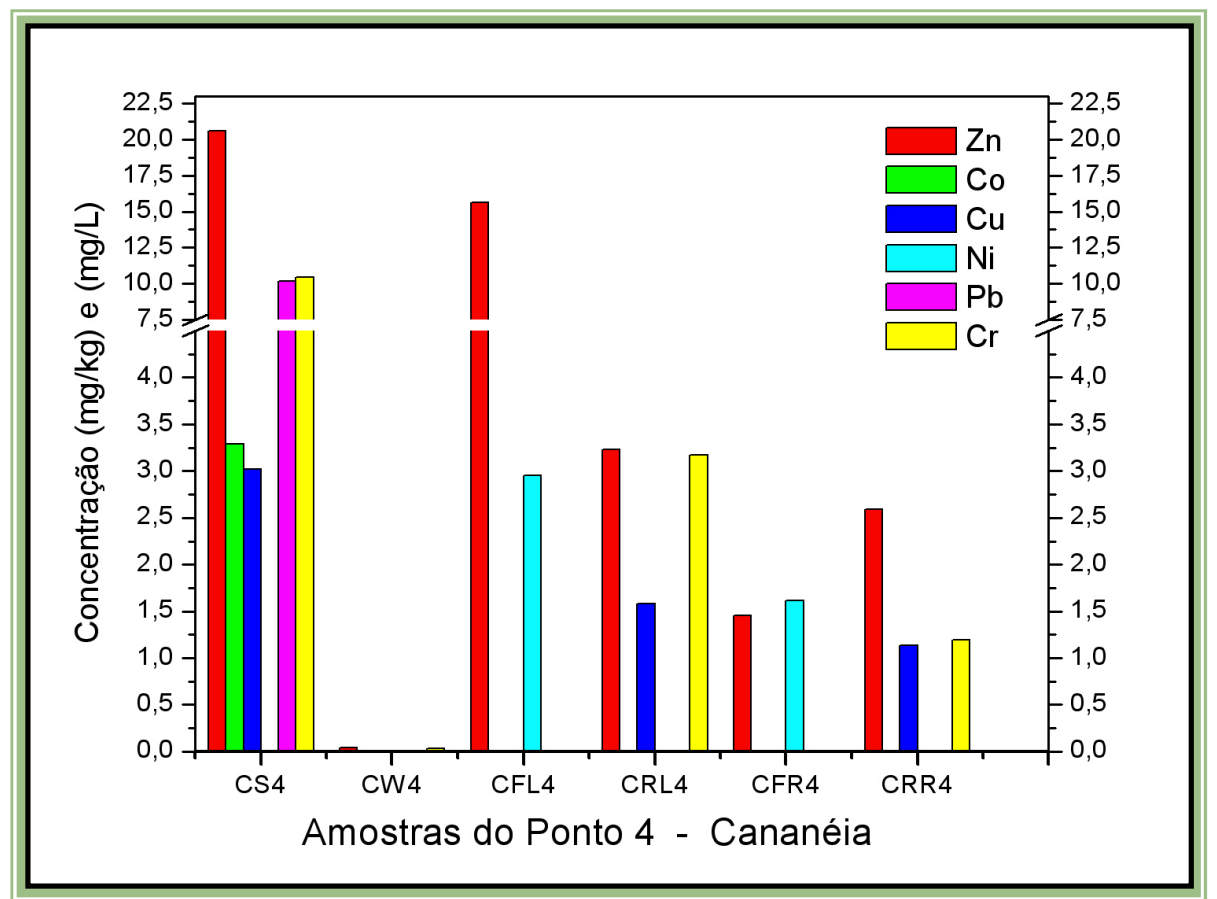

Figura 54a: Gráfico de comparação das concentrações de metais pseudo-totais em diferentes matrizes do ponto 4 do complexo estuarino de Cananéia.

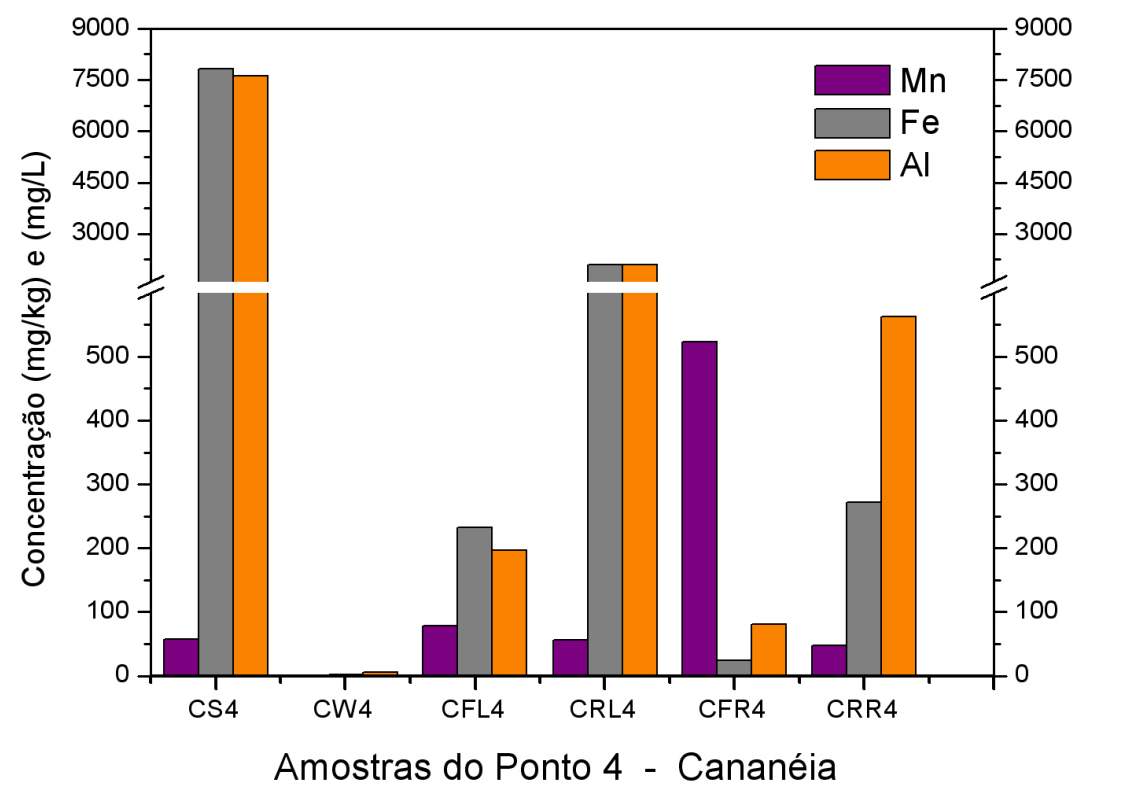

Figura 54b: Gráfico de comparação das concentrações de metais pseudo-totais em diferentes matrizes do ponto 4 do complexo estuarino de Cananéia. 


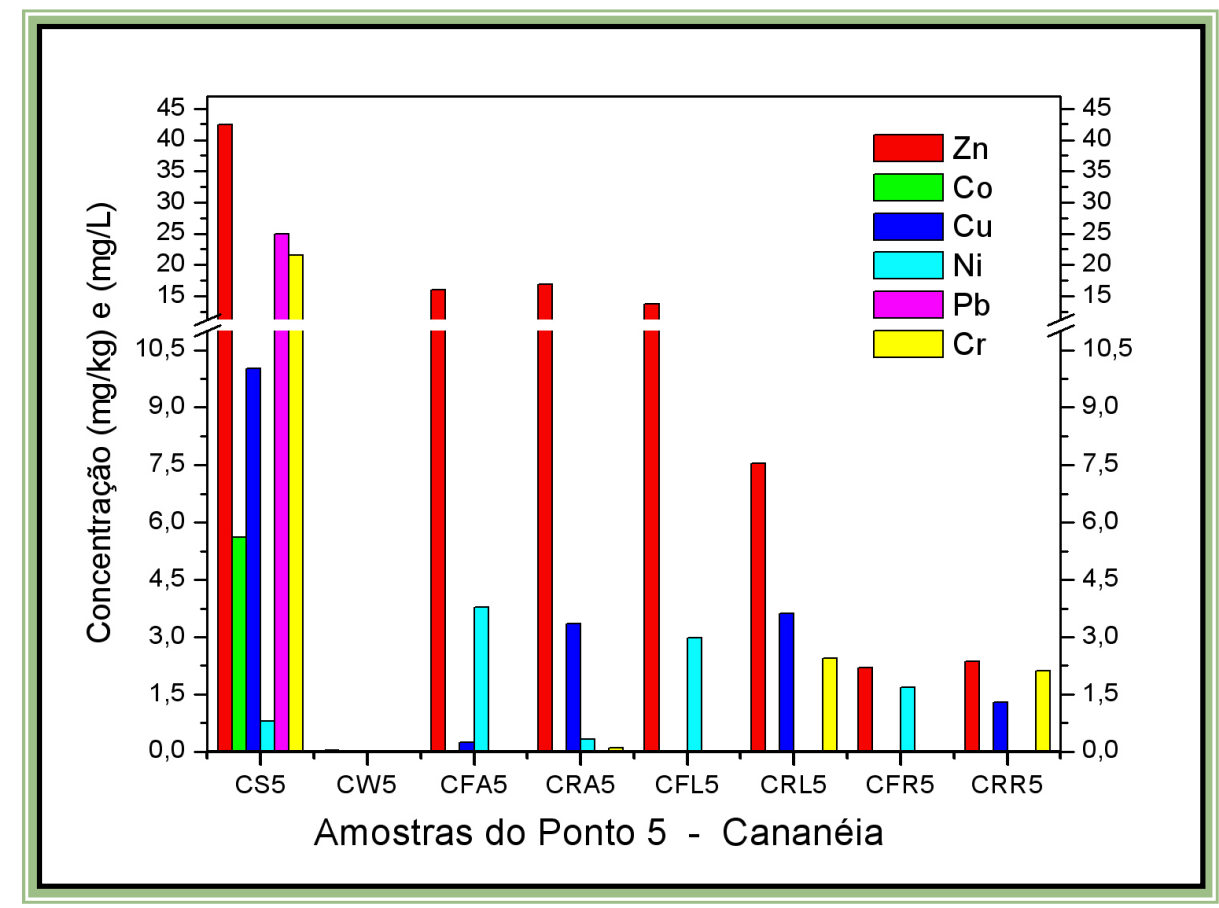

Figura 55a: Gráfico de comparação das concentrações de metais pseudo-totais em diferentes matrizes do ponto 5 do complexo estuarino de Cananéia.

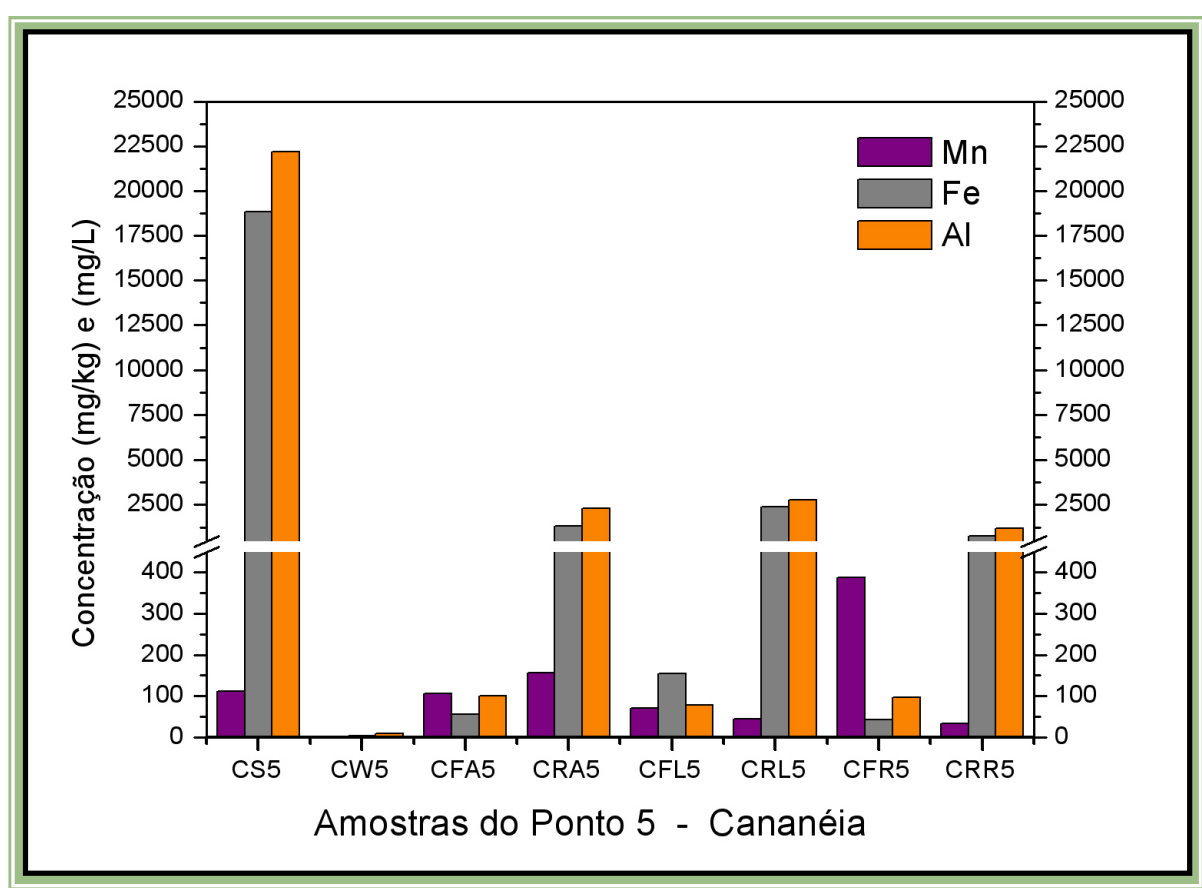

Figura 55b: Gráfico de comparação das concentrações de metais pseudo-totais em diferentes matrizes do ponto 5 do complexo estuarino de Cananéia. 


\subsection{Determinação de compostos organoclorados em amostras de sedimento e folhas e raízes de mangues}

A determinação de compostos organoclorados foi feita por GC-ECD, nas condições descritas no item 4.8.3, onde se utilizou o método do padrão externo e construiu-se gráficos de calibração com 5 concentrações distintas.

O cromatograma de separação dos 19 compostos estudados com seus devidos tempos de retenção pode ser observado na figura 56, enquanto os gráficos de calibração são apresentados nas figuras 57a e 57b.

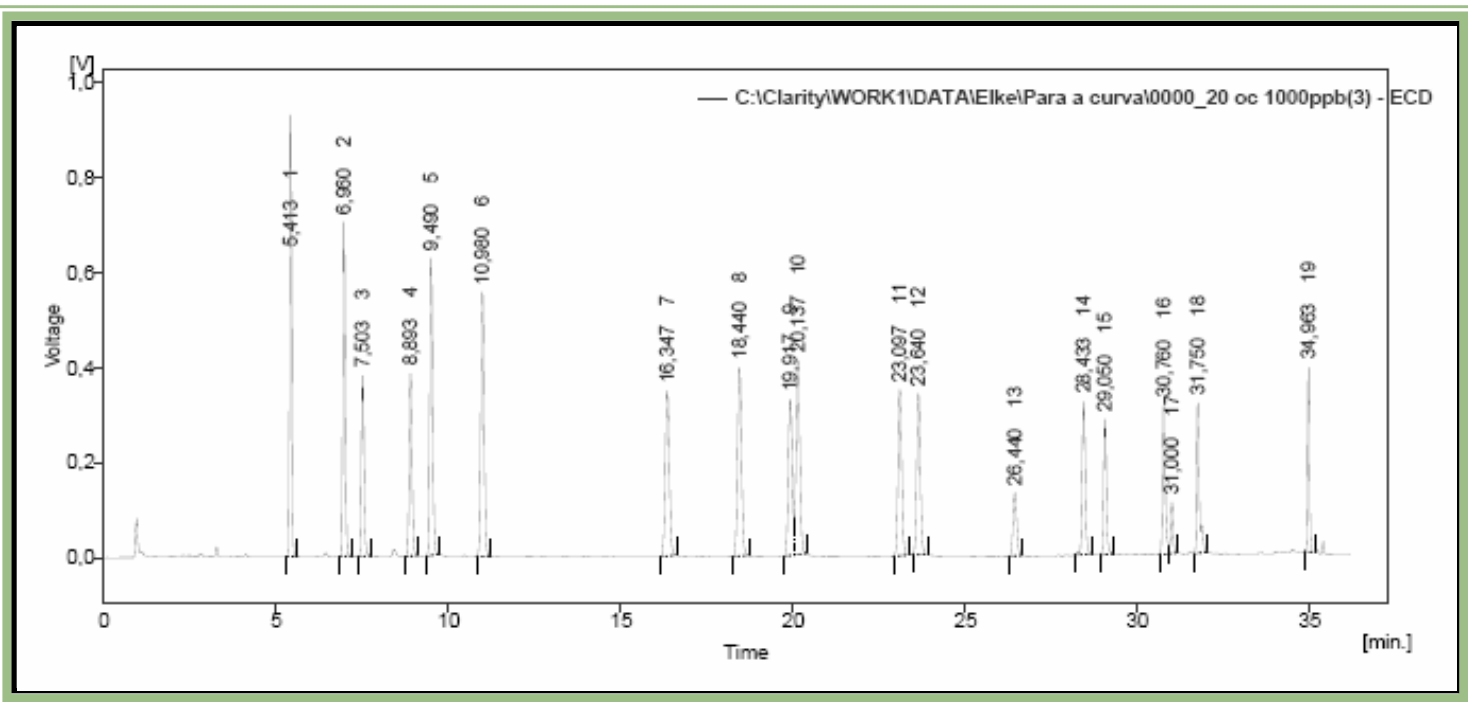

Figura 56: Cromatograma da separação de 19 compostos organoclorados: (1) $\alpha-\mathrm{HCH}$; (2) $\gamma$ $\mathrm{HCH}$; (3) $\beta$-HCH; (4) Heptacloro; (5) $\delta$ - $\mathrm{HCH}$; (6)Aldrin; (7) Heptacloro epóxido; (8) $\gamma$-Clordano; (9) $\alpha$-Endusulfan; (10) $\alpha$-Clordano; (11) Dieldrin; (12) $p, p$-DDE; (13) Endrin; (14) $\beta$-Endosulfan; (15) p,p-DDD; (16) Endrin aldeído; (17) p,p-DDT; (18) Endosulfan sulfato; (19) Endrin cetona. 


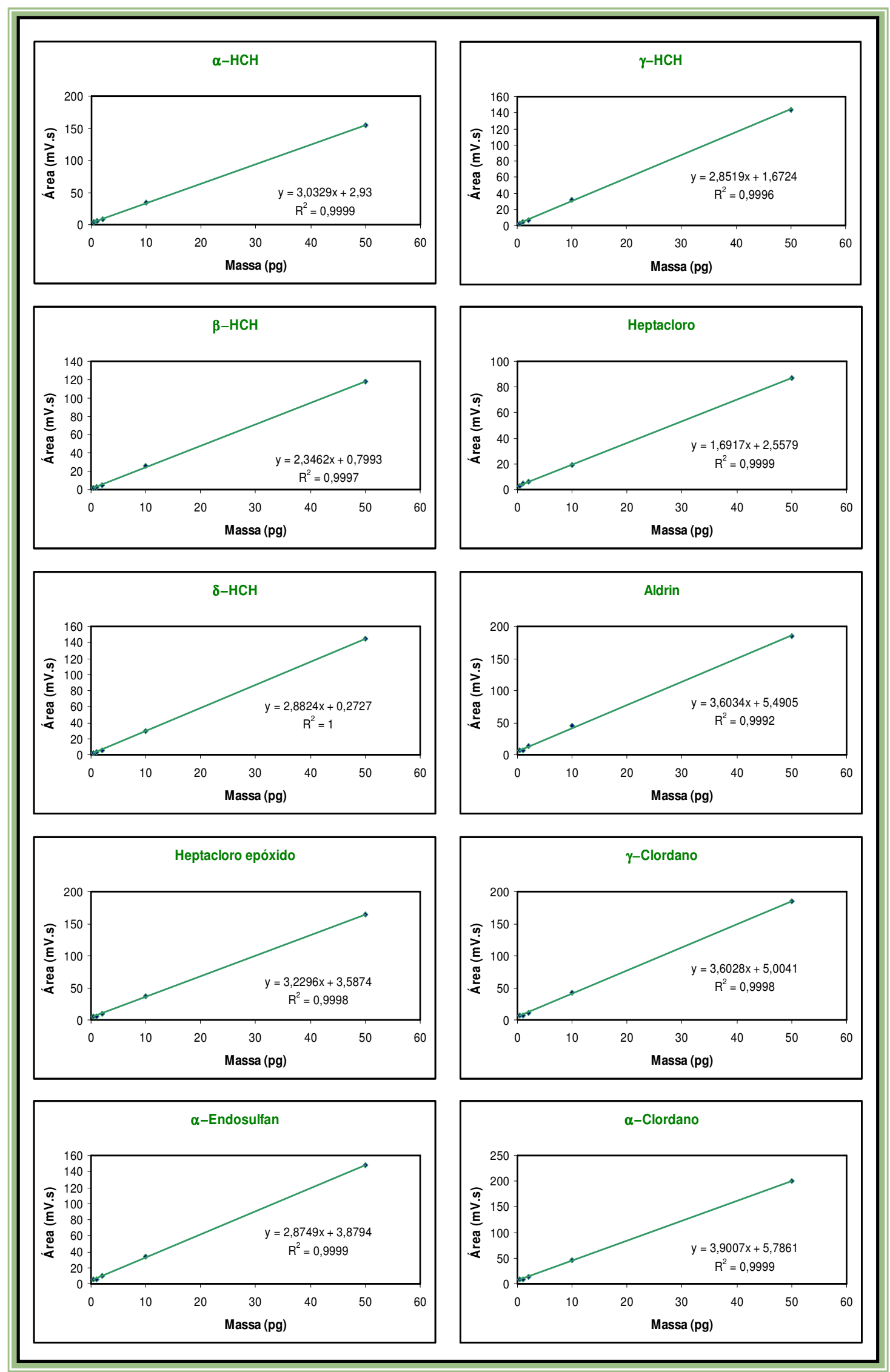

Figura 57a: Gráficos de Calibração para a determinação de organoclorados por GC-ECD. 


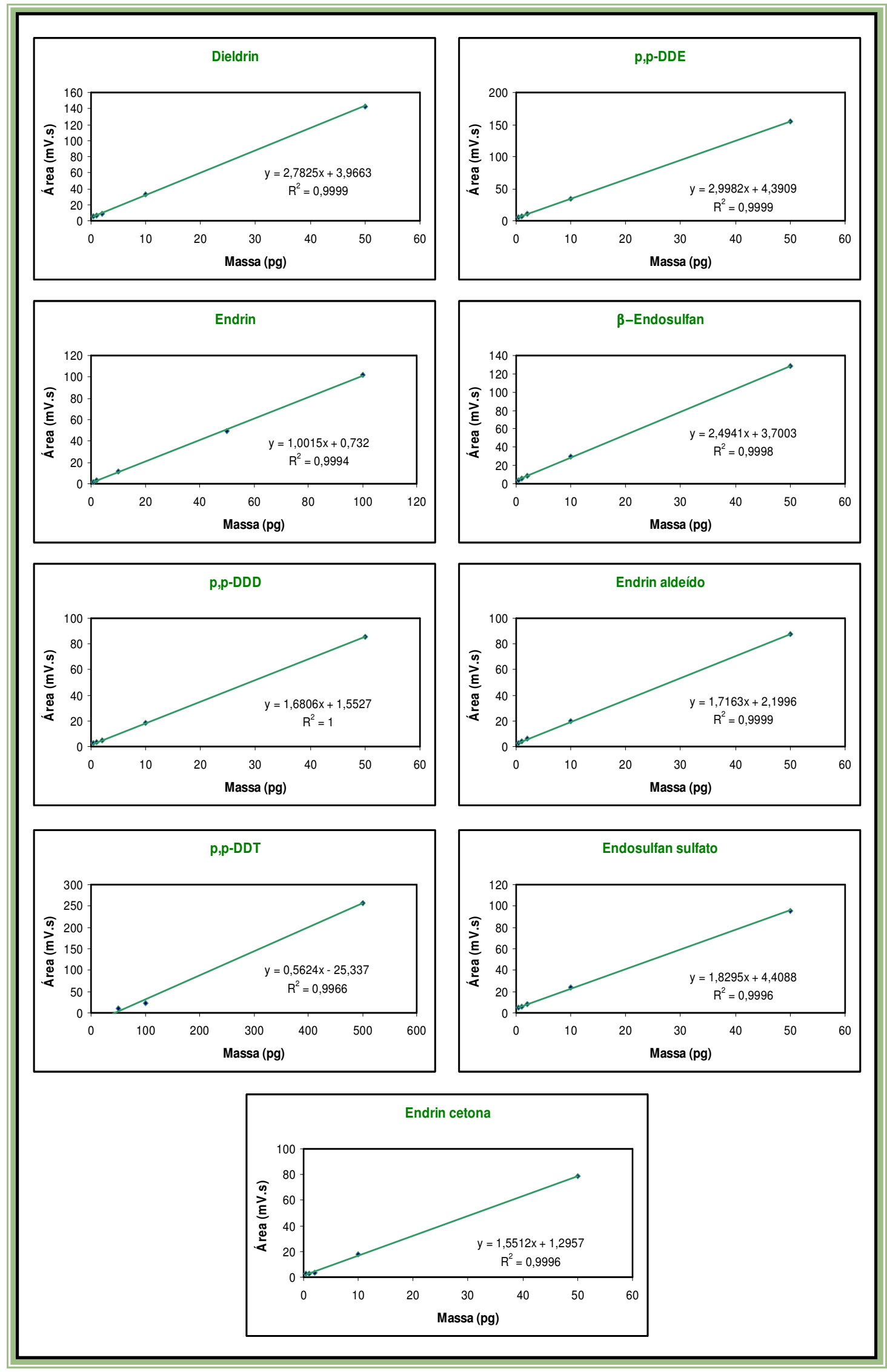

Figura 57b: Gráficos de Calibração para a determinação de organoclorados por GC-ECD. 
Os limites de detecção e quantificação se mostraram satisfatórios para a maioria dos compostos quando comparados com os limites de tolerância estabelecidos por diferentes fontes, conforme mostrados na tabela 14, tendo como exceções o endrin e principalmente o p,p-DDT.

Como citado anteriormente, a Lista Holandesa apresenta duas referências distintas, dependendo da proporção de matéria orgânica no sedimento, assim, para os pontos 3 da Baixada Santista e 2 e 3 de Cananéia, considerou-se a lista para sedimentos isentos de $\mathrm{OM}$, enquanto que para os outros pontos foram considerados os valores para sedimentos com $10 \%$ de OM. No entanto, ao observar a tabela 14, é notável a ausência de limites de tolerância para muitos pesticidas organoclorados, os quais não foi possível comparar com os resultados obtidos.

$\mathrm{Na}$ avaliação do método estabelecido neste trabalho, é possível verificar através dos resultados obtidos na tabela 15 que os valores do coeficiente de correlação $\left(R^{2}\right)$ são satisfatórios $(>0,99)$ de acordo com a Resolução no 899 da ANVISA. No entanto, para o p,p-DDT, observando a figura 57b, foi possível notar que o gráfico de calibração só contém 3 pontos de concentrações, que por sua vez são muito elevadas, o que resultou em um alto valor de LOQ. Desta maneira, os resultados para este composto são ignorados neste trabalho.

O segundo parâmetro estudado na avaliação do método foi a recuperação, a qual se mostrou satisfatória para os compostos: $\alpha-\mathrm{HCH}$ (média de 92,9\%); $\gamma-\mathrm{HCH}$ (média de 71,8 \%); heptacloro (média de 100,8\%); aldrin (média de $94 \%$ ); dieldrin (média de 73,5 \%); p,p-DDD (média de 87,2 \%); p,pDDE (média de $108 \%$ ); $\alpha$-clordano (média de 100,5 \%) e $\gamma$-clordano (média de $102,7 \%$ ) e insatisfatória para os outros compostos, uma vez que valores de recuperação dentro da faixa de 70 \% a 120 \% são aceitos, segundo Lanças (2004b). 
Tabela 14: Valores de $L O D$ e $L O Q$ encontrados e limites máximos permissíveis para pesticidas organoclorados a serem considerados neste estudo ${ }^{1}$.

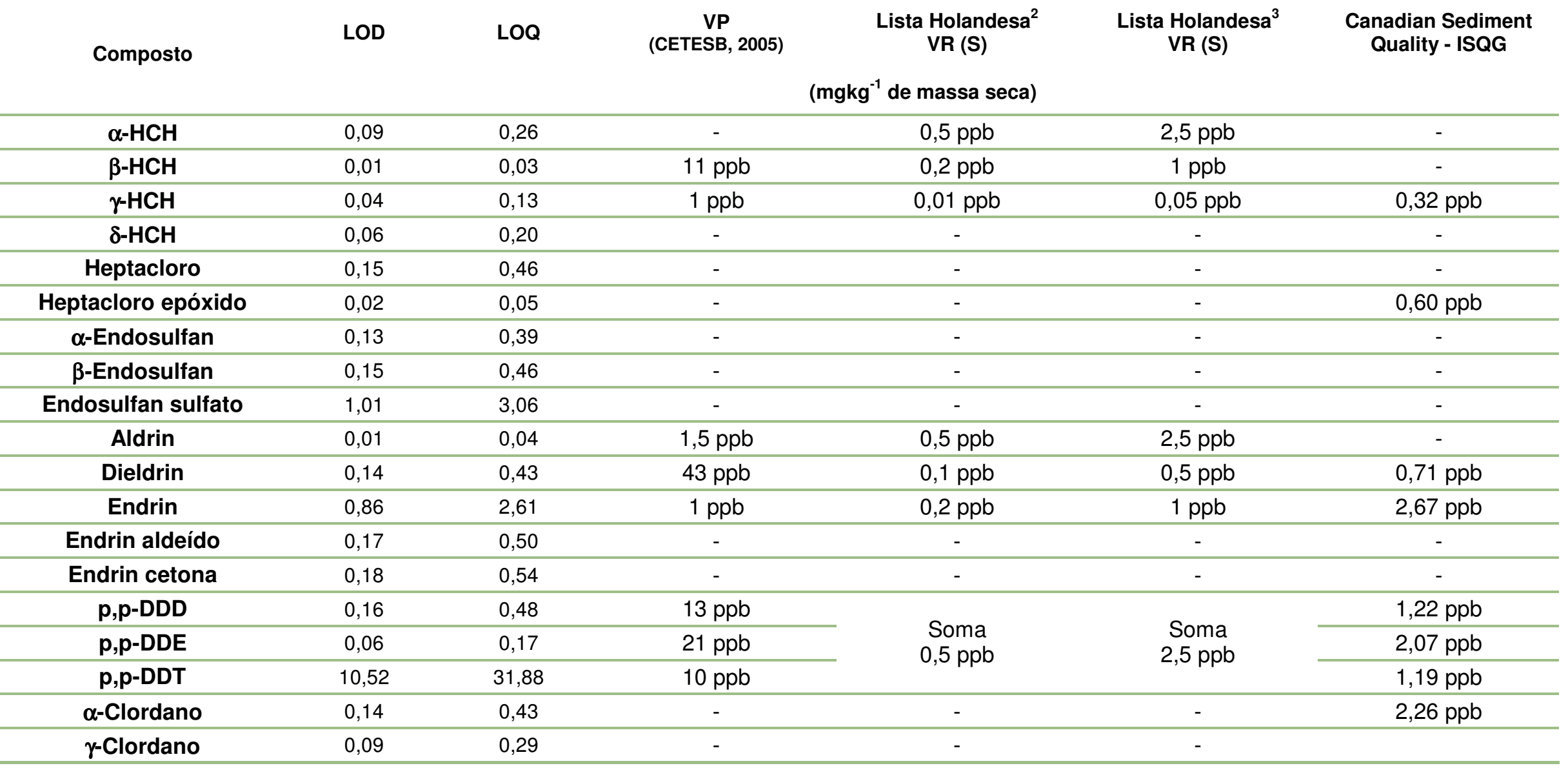

${ }^{1}$ As abreviaturas constam no início deste trabalho, na lista de abreviaturas;

${ }^{2}$ Lista Holandesa - valores de referência para solo com $0 \%$ de matéria orgânica;

${ }^{3}$ Lista Holandesa - valores de referência para solo com $10 \%$ de matéria orgânica. 
Tabela 15: Valores de $R^{2}$ encontrados e avaliação, em diferentes concentrações, do método utilizado para determinar compostos organoclorados ${ }^{1}$.

\begin{tabular}{|c|c|c|c|c|c|c|c|c|c|c|c|c|c|}
\hline \multirow[b]{2}{*}{ Composto } & \multirow{2}{*}{$\mathbf{R}^{2}$} & \multicolumn{4}{|c|}{$C=1 \mathrm{ngg}^{-1}$} & \multicolumn{4}{|c|}{$C=10 \mathrm{ngg}^{-1}$} & \multicolumn{4}{|c|}{$C=50 \mathrm{ngg}^{-1}$} \\
\hline & & $\begin{array}{l}\operatorname{Rec} \\
(\%)\end{array}$ & $\begin{array}{c}\text { Exat } \\
(\%)\end{array}$ & $\mathbf{S}$ & $\begin{array}{l}\text { CV } \\
(\%)\end{array}$ & $\begin{array}{l}\operatorname{Rec} \\
(\%)\end{array}$ & $\begin{array}{l}\text { Exat } \\
(\%)\end{array}$ & $\mathbf{S}$ & $\begin{array}{l}\text { CV } \\
\text { (\%) }\end{array}$ & $\begin{array}{l}\text { Rec } \\
(\%)\end{array}$ & $\begin{array}{l}\text { Exat } \\
(\%)\end{array}$ & $\mathbf{S}$ & $\begin{array}{l}\text { CV } \\
\text { (\%) }\end{array}$ \\
\hline$\alpha-\mathrm{HCH}$ & 0,9999 & 97,5 & 101,0 & 2,603 & 2,669 & 91,8 & 91,5 & 0,326 & 0,355 & 89,5 & 100,5 & 1,099 & 1,228 \\
\hline$\beta-\mathrm{HCH}$ & 09997 & 45,7 & 47,1 & 1,340 & 2,930 & 45,2 & 44,7 & 1,046 & 2,314 & 43,5 & 43,1 & 1,484 & 3,415 \\
\hline$\gamma-\mathrm{HCH}$ & 0,9996 & 72,9 & 76,7 & 3,620 & 4,964 & 71,6 & 71,1 & 3,529 & 4,930 & 71,0 & 74,9 & 4,736 & 6,667 \\
\hline$\delta-\mathrm{HCH}$ & 1,0 & 43,7 & 43,9 & 1,186 & 2,715 & 43,6 & 43,5 & 1,134 & 2,601 & 45,8 & 50,0 & 2,157 & 4,710 \\
\hline Heptacloro & 0,9999 & 105,3 & 104,9 & 5,365 & 5,093 & 100,8 & 100,8 & 4,618 & 4,584 & 96,2 & 103,2 & 6,409 & 6,665 \\
\hline Heptacloro epóxido & 0,9998 & 48,2 & 45,1 & 3,218 & 6,672 & 47,7 & 46,4 & 2,383 & 4,998 & 49,4 & 49,5 & 1,508 & 3,052 \\
\hline$\alpha$-Endosulfan & 0,9999 & 38,4 & 31,3 & 0,399 & 1,040 & 37,7 & 35,9 & 3,641 & 9,668 & 33,3 & 33,3 & 1,296 & 3,896 \\
\hline$\beta$-Endosulfan & 0,9998 & 34,8 & 26,7 & 1,499 & 4,312 & 31,6 & 29,5 & 0,771 & 2,438 & 30,7 & 30,6 & 1,753 & 5,720 \\
\hline Endosulfan sulfato & 0,9996 & 48,7 & 39,4 & 2,002 & 4,108 & 44,1 & 41,3 & 1,898 & 4,309 & 45,6 & 46,9 & 0,936 & 2,051 \\
\hline Aldrin & 0,9992 & 97,3 & 117,1 & 1,483 & 1,523 & 90,6 & 90,0 & 0,509 & 0,562 & 94,2 & 96,1 & 3,523 & 3,739 \\
\hline Dieldrin & 0,9999 & 72,5 & 71,3 & 5,440 & 7,501 & 75,3 & 74,5 & 4,983 & 6,615 & 72,7 & 73,8 & 3,168 & 4,356 \\
\hline Endrin & 0,9994 & 26,4 & 22,2 & 0,777 & 2,944 & 25,9 & 22,6 & 1,026 & 3,958 & 29,2 & 28,5 & 0,666 & 2,285 \\
\hline Endrin aldeído & 0,9999 & 39,5 & 40,0 & 2,895 & 7,320 & 36,8 & 35,1 & 1,535 & 4,173 & 40,2 & 39,2 & 1925 & 4,784 \\
\hline Endrin cetona & 0,9996 & 31,2 & 60,6 & 1,792 & 5,743 & 29,8 & 28,6 & 1,472 & 4,938 & 33,2 & 36,9 & 0,386 & 1,162 \\
\hline p,p-DDD & 1,0 & 84,5 & 83,8 & 2,049 & 2,426 & 82,2 & 81,8 & 3,815 & 4,643 & 94,8 & 103,1 & 4,984 & 5,260 \\
\hline p,p-DDE & 0,9999 & 119,8 & 119,8 & 7,994 & 6,672 & 104,1 & 104,3 & 5,045 & 4,846 & 100,2 & 93,8 & 4,504 & 4,498 \\
\hline p,p-DDT & 0,9966 & - & - & - & - & - & - & - & - & - & - & - & - \\
\hline$\alpha$-Clordano & 0,9999 & 109,1 & 113,3 & 5,145 & 4,714 & 97,7 & 97,5 & 2,317 & 2,372 & 94,7 & 96,5 & 1,151 & 1,215 \\
\hline$\gamma$-Clordano & 0,9998 & 113,7 & 120,8 & 9,658 & 8,494 & 100,5 & 100,4 & 3,691 & 3,672 & 94,0 & 94,5 & 1,928 & 2,051 \\
\hline
\end{tabular}

\footnotetext{
${ }^{1}$ As abreviaturas constam no início deste trabalho, na lista de abreviaturas.
} 
O parâmetro exatidão também se mostrou satisfatório para os compostos: $\alpha-\mathrm{HCH}$ (média de 97,7\%); heptacloro (média de $103 \%$ ); aldrin (média de 101,1\%); p,p-DDD (média de 89,6 \%); p,p-DDE (média de $106 \%$ ); $\alpha$-clordano (média de 102,4 \%) e $\gamma$-clordano (média de 105,2\%), uma vez que estes apresentaram desvios dentro dos valores (<20 \%) recomendados pela Resolução no 899 da ANVISA. No entanto, para os outros compostos a exatidão foi insatisfatória, até mesmo para os compostos $\gamma-\mathrm{HCH}$ (média de 74,2 \%) e dieldrin (média de 73,2 \%), que apresentaram boa recuperação.

De acordo com a Resolução no 899 da ANVISA, a precisão, através dos valores de desvio padrão e do coeficiente de variação, se mostrou satisfatória para todos os compostos, com exceção do p,p-DDT que não teve seus resultados considerados.

A tabela 16 mostra os resultados obtidos para as concentrações de compostos organoclorados em amostras de sedimento das regiões de estudo. É possível observar que na maioria dos resultados, os compostos organoclorados presentes estão muito acima dos limites de tolerância das legislações consideradas.

De uma forma geral, os limites de tolerância indicados pelo Canadian Sediment Quality Guidelines (que se refere a sedimentos) estão abaixo dos valores de referência de qualidade para solos da CETESB. Sendo assim, compostos que apresentam concentrações acima dos valores de referência considerados pela CETESB estão muito além dos limites estabelecidos pelo Canadian Sediment Quality Guidelines.

É importante ressaltar ainda que, deve ser levado em consideração os valores de recuperação, portanto, compostos como o $\beta-\mathrm{HCH}$ e o heptacloro epóxido que apresentaram baixos valores de recuperação (médias de 44,8 \% e $48,4 \%$, respectivamente), e concentrações nas amostras acima dos limites estabelecidos pelas legislações, indicam que estas estão contaminadas, uma vez que os valores reais podem estar ainda acima dos obtidos. 
Tabela 16: Concentrações de pesticidas organoclorados encontradas em amostras de sedimento dos complexos estuarinos estudados ${ }^{1}$.

Concentração de compostos organoclorados em amostras de sedimento $\left(\mathrm{ngg}^{-1}\right)$

\begin{tabular}{|c|c|c|c|c|c|c|c|c|c|c|c|c|c|c|c|c|c|c|c|}
\hline 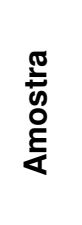 & $\begin{array}{l}\frac{1}{0} \\
\frac{1}{d}\end{array}$ & $\begin{array}{l}\frac{T}{U} \\
\frac{1}{a} \\
0\end{array}$ & $\begin{array}{l}\frac{T}{U} \\
\frac{1}{d}\end{array}$ & $\begin{array}{l}\text { T } \\
\text { T⿱宀 } \\
\dot{1}\end{array}$ & $\begin{array}{l}\text { 은 } \\
\frac{0}{0} \\
\frac{\pi}{0} \\
\frac{0}{0}\end{array}$ & 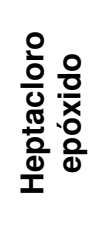 & 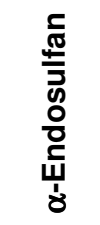 & 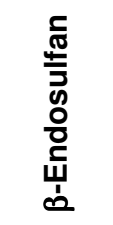 & 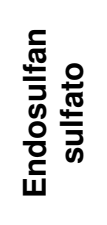 & $\frac{\mathfrak{c}}{\frac{5}{0}}$ & $\frac{\text { 든 }}{\frac{0}{0}}$ & $\frac{\mathfrak{c}}{\frac{5}{0}}$ & 든 응 & 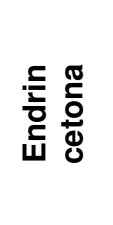 & $\begin{array}{l}\text { 음 } \\
\frac{1}{\alpha} \\
\frac{0}{2}\end{array}$ & 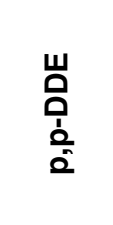 & $\begin{array}{l}5 \\
\frac{\circ}{2} \\
\frac{2}{2}\end{array}$ & $\begin{array}{l}\frac{0}{1} \\
\frac{\pi}{0} \\
\frac{0}{0} \\
\frac{1}{8}\end{array}$ & $\begin{array}{l}\frac{0}{\frac{1}{0}} \\
\frac{0}{0} \\
\frac{0}{0} \\
\frac{1}{x}\end{array}$ \\
\hline s1 & $<L O D$ & ND & 2,71 & 0,20 & 0,74 & ND & ND & $<L O Q$ & 3,17 & $<L O D$ & $<L O D$ & ND & 9,95 & ND & 3,64 & $<L O D$ & ND & $<L O D$ & $<L O Q$ \\
\hline S2 & 14,01 & 5,46 & 14,15 & ND & 8,81 & ND & 4,71 & ND & $<L O D$ & 7,91 & ND & ND & 0,55 & ND & 1,62 & 1,51 & ND & 4,79 & 10,01 \\
\hline S3 & ND & 0,09 & 2,65 & $<L O D$ & $<L O Q$ & $<L O D$ & 2,71 & 0,71 & $<L O Q$ & 0,09 & ND & $<L O D$ & 2,70 & 7,41 & 1,02 & ND & ND & 2,61 & ND \\
\hline S4 & ND & 9,63 & 14,36 & 4,99 & 20,17 & 6,40 & 3,01 & 2,45 & 12,87 & 6,93 & ND & ND & 9,85 & 43,78 & 10,24 & ND & ND & 2,63 & ND \\
\hline S5 & ND & 25,24 & 39,43 & $<L O Q$ & 54,40 & 10,33 & 34,46 & ND & 8,91 & $<L O Q$ & ND & ND & 18,17 & ND & ND & ND & ND & 13,95 & 12,33 \\
\hline CS1 & ND & 17,12 & 22,37 & ND & 42,59 & 5,89 & ND & 10,00 & 22,78 & ND & ND & ND & ND & ND & 8,26 & ND & ND & 13,78 & ND \\
\hline CS2 & ND & ND & 7,17 & ND & ND & ND & 0,59 & ND & $<L O D$ & 1,32 & ND & ND & $<L O D$ & ND & ND & ND & ND & 0,65 & ND \\
\hline CS3 & ND & 8,32 & 11,70 & ND & 20,35 & 2,71 & ND & ND & 7,21 & 7,51 & ND & ND & ND & ND & 9,22 & ND & ND & 7,11 & ND \\
\hline CS4 & ND & 17,82 & 22,38 & ND & 43,03 & 7,13 & ND & 2,07 & 8,91 & ND & ND & ND & ND & ND & ND & ND & ND & 13,91 & 10,54 \\
\hline CS5 & 0,35 & ND & 2,32 & ND & $<L O D$ & ND & ND & ND & 54,78 & $<L O D$ & ND & ND & ND & ND & ND & ND & ND & 5,75 & ND \\
\hline
\end{tabular}

${ }^{1}$ As abreviaturas constam no início deste trabalho, na lista de abreviaturas.

: Valores acima de VRQ - CETESB

: Valores acima de VR(S) - Lista Holandesa

: Valores acima de ISQG - Canadian Sediment Quality Guidelines 
Compostos como o endrin cetona, por exemplo, que confere uma concentração igual a 43,78 ppb no ponto 4 da Baixada santista, e o endosulfan sulfato que tem como resultado 54,78 ppb no ponto 5 de Cananéia, não apresentam limites de tolerância nas legislações em questão. Desta forma, verifica-se a importância de se estabelecer valores máximos permissíveis para estes e outros compostos organoclorados potencialmente tóxicos, uma vez que os mesmos não são compostos naturais nos ecossistemas de manguezais.

O lindano, $\gamma-\mathrm{HCH}$, que apresentou recuperação aceitável (média de $71,8 \%$ ) se mostrou presente em todos os pontos de coleta com concentrações entre 2 e 39 vezes acima dos limites estabelecidos pela CETESB e 7 a 197 vezes acima dos limites de tolerância do Canadian Sediment Quality Guidelines. Esta substância é altamente tóxica e bioacumulativa, onde altas concentrações podem causar efeitos prejudiciais à vida em ambientes aquáticos.

Para as amostras de folhas e raízes de mangues não há legislação específica que determine limites de tolerância para pesticidas clorados. No entanto, sabe-se que não faz parte da fisiologia destas espécies qualquer quantidade destes compostos, de tal maneira que não se espera a presença dos mesmos, ao contrário do que demonstraram os resultados nas tabelas 17 , 18,19 e 20.

Alguns pontos de coleta ainda resultaram em valores de concentração elevados para determinados compostos nas plantas de manguezais, se considerarmos as legislações estabelecidas para solos e sedimentos. A amostra de raiz Avicennia Schaueriana do ponto 4 da Baixada Santista por exemplo, apresentou 12,36 ppb de $\gamma-\mathrm{HCH}, 21,88$ ppb de endrin aldeído e 61,73 ppb de a-clordano, além de outros compostos. Outros exemplos são as amostras de folhas de Rhizophora Mangle no ponto 2 da Baixada Santista que apresentou 34,43 ppb de heptacloro e 14,03 ppb de dieldrin. Em adição a estas informações, é claro, deve-se considerar os valores obtidos para recuperação. 
Tabela 17: Concentrações de pesticidas organoclorados encontradas em amostras de folhas de mangues do complexo estuarino da Baixada Santista ${ }^{1}$.

Concentração de compostos organoclorados em amostras de folhas de mangues $\left(\mathrm{ngg}^{-1}\right)$

\begin{tabular}{|c|c|c|c|c|c|c|c|c|c|c|c|c|c|c|c|c|c|c|c|}
\hline 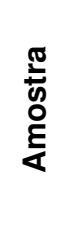 & $\begin{array}{l}\frac{1}{0} \\
\frac{1}{1} \\
\delta\end{array}$ & $\begin{array}{l}\frac{I}{0} \\
\text { T⿱ } \\
\dot{a}\end{array}$ & $\begin{array}{l}\frac{1}{0} \\
\frac{1}{d} \\
\frac{1}{d}\end{array}$ & 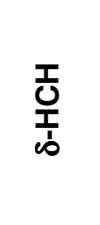 & $\begin{array}{l}\frac{0}{0} \\
\frac{0}{U} \\
\frac{\pi}{0} \\
\frac{0}{0} \\
\text { I }\end{array}$ & $\begin{array}{l}\text { 인 응 } \\
\frac{0}{0} \\
\frac{0}{x} \\
\frac{\pi}{0} \\
\frac{0}{0} \\
\frac{0}{1}\end{array}$ & $\begin{array}{l}\frac{5}{\pi} \\
\frac{\pi}{5} \\
\frac{0}{0} \\
\frac{0}{0} \\
\frac{1}{4} \\
\grave{1}\end{array}$ & 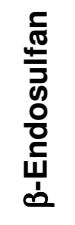 & 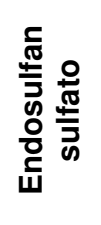 & $\frac{5}{\frac{5}{0}}$ & $\begin{array}{l}\frac{.}{\frac{1}{2}} \\
\frac{0}{0} \\
\frac{0}{0}\end{array}$ & 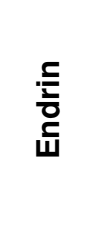 & $\begin{array}{l}\text { 은 응 } \\
\text { 는 음 }\end{array}$ & 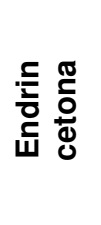 & 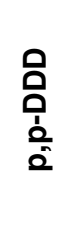 & 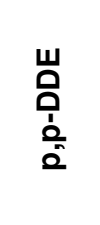 & 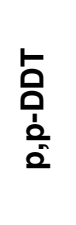 & $\begin{array}{l}\text { 음 } \\
\frac{\pi}{0} \\
\frac{0}{0} \\
\frac{0}{0} \\
\frac{1}{0}\end{array}$ & $\begin{array}{l}\text { 은 } \\
\frac{\pi}{0} \\
\frac{0}{0} \\
\frac{1}{1}\end{array}$ \\
\hline FA1 & ND & ND & 1,15 & ND & $<L O D$ & ND & ND & ND & ND & 0,31 & ND & ND & ND & ND & ND & $<$ LOD & ND & ND & $<L O D$ \\
\hline FL1 & ND & ND & 1,06 & ND & 0,62 & ND & ND & ND & ND & ND & ND & ND & ND & 0,99 & ND & ND & ND & ND & ND \\
\hline FA2 & ND & ND & 2,49 & 0,32 & 1,73 & ND & ND & ND & $<L O D$ & 0,17 & ND & $<$ LOD & 3,82 & 2,88 & ND & ND & ND & $<\mathrm{LOQ}$ & ND \\
\hline FL2 & ND & ND & 1,31 & ND & 0,61 & ND & ND & ND & ND & $<L O D$ & ND & ND & ND & ND & ND & ND & ND & $<$ LOD & ND \\
\hline FR2 & 5,71 & ND & 1,11 & ND & 34,43 & ND & ND & ND & ND & $<L O Q$ & 14,03 & ND & ND & ND & ND & ND & ND & $<$ LOD & $<L O Q$ \\
\hline FA3 & ND & ND & 1,49 & ND & 5,95 & ND & ND & ND & ND & 3,40 & ND & ND & 0,67 & ND & ND & ND & ND & ND & ND \\
\hline FL3 & ND & ND & 1,32 & ND & $<L O Q$ & ND & ND & ND & ND & ND & ND & ND & ND & ND & ND & ND & ND & ND & ND \\
\hline FR3 & ND & ND & $<L O D$ & ND & ND & ND & ND & ND & ND & ND & ND & ND & ND & ND & ND & ND & ND & ND & ND \\
\hline FA4 & 0,49 & 0,31 & 5,56 & 1,26 & 5,10 & ND & ND & ND & $<L O D$ & $<L O D$ & 0,69 & 3,14 & 1,58 & ND & ND & ND & ND & 5,12 & ND \\
\hline FL4 & ND & ND & 1,13 & $<L O Q$ & 0,59 & ND & ND & ND & ND & ND & ND & ND & ND & 1,60 & ND & ND & ND & ND & ND \\
\hline FR4 & $<\mathrm{LOD}$ & 1,29 & 0,69 & ND & $<L O Q$ & ND & ND & ND & ND & $<L O D$ & ND & ND & ND & ND & ND & ND & ND & ND & ND \\
\hline FA5 & $<\mathrm{LOD}$ & ND & ND & $<L O Q$ & ND & ND & ND & ND & ND & ND & ND & ND & ND & ND & ND & $<$ LOD & ND & ND & ND \\
\hline FL5 & ND & ND & ND & 0,64 & $<L O Q$ & ND & ND & ND & ND & ND & ND & ND & ND & ND & ND & ND & ND & ND & ND \\
\hline FR5 & 2,62 & ND & ND & ND & 0,54 & ND & ND & ND & ND & 1,44 & ND & ND & ND & ND & ND & ND & ND & ND & ND \\
\hline
\end{tabular}

${ }^{1}$ As abreviaturas constam no início deste trabalho, na lista de abreviaturas. 
Tabela 18: Concentrações de pesticidas organoclorados encontradas em amostras de folhas de mangues do complexo estuarino de Cananéia'.

Concentração de compostos organoclorados em amostras de folhas de mangues $\left(\mathrm{ngg}^{-1}\right)$

\begin{tabular}{|c|c|c|c|c|c|c|c|c|c|c|c|c|c|c|c|c|c|c|c|}
\hline $\begin{array}{l}\frac{\pi}{5} \\
\frac{0}{0} \\
\stackrel{2}{\alpha}\end{array}$ & $\begin{array}{l}\frac{1}{0} \\
\frac{1}{d}\end{array}$ & $\begin{array}{l}\frac{I}{0} \\
\frac{T}{b} \\
\dot{a}\end{array}$ & $\begin{array}{l}\frac{T}{U} \\
\frac{1}{d}\end{array}$ & 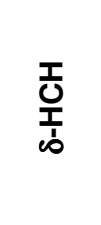 & $\begin{array}{l}\text { 은 } \\
\frac{0}{0} \\
\frac{\pi}{0} \\
\frac{0}{0} \\
\frac{1}{1}\end{array}$ & 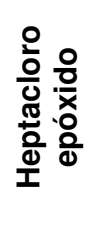 & 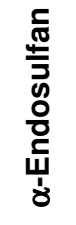 & 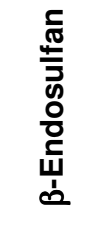 & 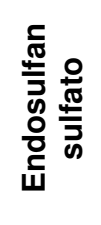 & $\frac{5}{\frac{5}{2}}$ & $\begin{array}{l}\frac{5}{2} \\
\frac{0}{0} \\
\square\end{array}$ & 元 & 돟 응 & 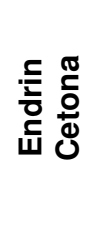 & 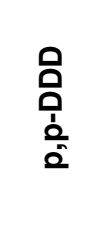 & 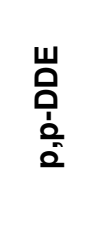 & $\begin{array}{l}\text { 号 } \\
\text { ò } \\
\text { on }\end{array}$ & $\begin{array}{l}\frac{0}{\frac{1}{0}} \\
\frac{1}{0} \\
\frac{0}{0} \\
\frac{1}{0}\end{array}$ & $\begin{array}{l}\frac{0}{\frac{1}{0}} \\
\frac{\pi}{0} \\
\frac{0}{0} \\
\frac{1}{1}\end{array}$ \\
\hline CFA1 & ND & ND & $<L O D$ & ND & 4,62 & ND & ND & ND & ND & 0,07 & ND & ND & ND & ND & ND & 1,22 & ND & ND & 2,45 \\
\hline CFL1 & $<L O D$ & ND & 1,29 & ND & 1,98 & ND & ND & ND & ND & ND & ND & ND & ND & ND & 1,21 & ND & ND & ND & ND \\
\hline CFR1 & ND & ND & $<L O D$ & $<L O Q$ & ND & ND & ND & ND & ND & ND & ND & ND & $<L O D$ & 2,08 & ND & ND & ND & ND & ND \\
\hline CFA2 & 0,56 & ND & 0,71 & ND & 0,85 & ND & ND & $<L O D$ & ND & 3,21 & ND & ND & ND & ND & $<L O D$ & 0,98 & ND & $<$ LOD & $<\mathrm{LOD}$ \\
\hline CFL2 & $<L O D$ & ND & 1,07 & ND & ND & ND & ND & ND & ND & ND & ND & ND & ND & ND & ND & ND & ND & ND & $<L O D$ \\
\hline CFR2 & ND & ND & $<L O D$ & ND & 1,11 & ND & ND & ND & ND & ND & ND & ND & ND & ND & ND & ND & ND & ND & ND \\
\hline CFA3 & 0,78 & ND & 0,68 & ND & ND & ND & ND & ND & ND & $<L O D$ & ND & ND & ND & ND & 1,01 & 1,76 & ND & ND & ND \\
\hline CFL3 & 0,80 & ND & 3,77 & ND & 1,34 & ND & ND & ND & ND & $<L O D$ & ND & ND & 1,94 & ND & ND & 1,51 & ND & ND & $<\mathrm{LOD}$ \\
\hline CFR3 & ND & ND & ND & ND & ND & ND & ND & ND & ND & 1,06 & ND & ND & ND & 3,25 & ND & ND & ND & ND & ND \\
\hline CFL4 & ND & ND & 0,25 & ND & $<L O D$ & ND & ND & ND & ND & $<L O D$ & ND & ND & ND & ND & ND & ND & ND & $<$ LOD & ND \\
\hline CFR4 & ND & ND & $<L O D$ & ND & ND & ND & ND & ND & ND & ND & ND & ND & ND & ND & ND & 0,55 & ND & ND & ND \\
\hline CFA5 & ND & ND & ND & 0,46 & ND & ND & ND & ND & ND & ND & ND & ND & ND & ND & ND & ND & ND & ND & ND \\
\hline CFL5 & ND & ND & 0,95 & ND & ND & ND & ND & ND & ND & ND & ND & ND & ND & ND & ND & ND & ND & ND & ND \\
\hline CFR5 & 0,60 & 4,66 & 1,08 & ND & 2,31 & ND & ND & ND & ND & 1,40 & 0,51 & ND & ND & ND & ND & ND & ND & $<L O D$ & ND \\
\hline
\end{tabular}

${ }^{1}$ As abreviaturas constam no início deste trabalho, na lista de abreviaturas. 
Tabela 19: Concentrações de pesticidas organoclorados encontradas em amostras de raízes de mangues do complexo estuarino da Baixada Santista'.

Concentração de compostos organoclorados em amostras de raízes de mangues (ngg ${ }^{-1}$ )

\begin{tabular}{|c|c|c|c|c|c|c|c|c|c|c|c|c|c|c|c|c|c|c|c|}
\hline 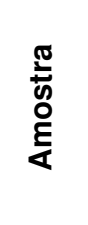 & $\begin{array}{l}\frac{1}{0} \\
\frac{1}{d}\end{array}$ & $\begin{array}{l}\frac{I}{0} \\
\frac{T}{b} \\
\dot{a}\end{array}$ & $\begin{array}{l}\frac{T}{U} \\
\frac{1}{d}\end{array}$ & 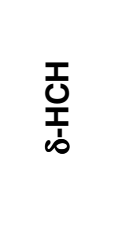 & 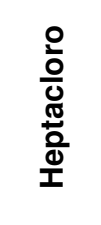 & 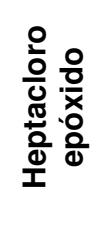 & 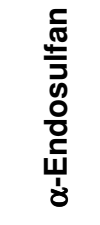 & 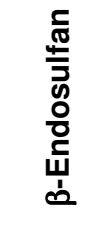 & 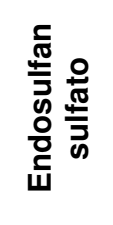 & $\frac{\text { 듬 }}{\frac{3}{4}}$ & 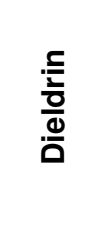 & 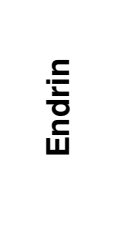 & $\begin{array}{l}\text { 옿 } \frac{0}{0} \\
\text { 뜸 }\end{array}$ & 돓 & 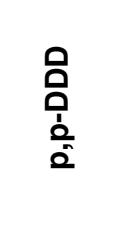 & 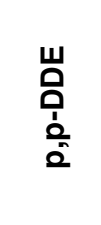 & 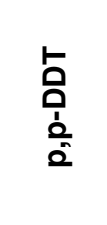 & $\begin{array}{l}\frac{0}{\frac{1}{0}} \\
\frac{1}{0} \\
\frac{0}{0} \\
\frac{1}{0}\end{array}$ & $\begin{array}{l}\frac{0}{c} \\
\frac{\pi}{0} \\
\text { 흔 } \\
\frac{1}{1}\end{array}$ \\
\hline RA1 & 0,70 & 0,71 & 1,07 & 1,30 & 0,59 & ND & 4,39 & 2,11 & ND & 1,41 & ND & ND & ND & ND & 0,93 & 0,68 & ND & ND & 7,46 \\
\hline RL1 & ND & ND & ND & ND & $<L O D$ & ND & ND & ND & ND & $<L O D$ & ND & ND & 0,56 & ND & ND & ND & ND & ND & ND \\
\hline RA2 & 0,70 & 3,38 & 3,00 & ND & 0,92 & 0,16 & $<\mathrm{LOQ}$ & ND & ND & $<L O D$ & ND & ND & ND & ND & 1,42 & $<L O Q$ & ND & $<L O Q$ & $<\mathrm{LOD}$ \\
\hline RL2 & $<L O D$ & ND & 1,20 & 0,30 & 0,66 & ND & 0,53 & ND & $<\mathrm{LOQ}$ & 0,93 & ND & 5,08 & ND & 15,73 & $<L O D$ & ND & ND & 3,83 & $<\mathrm{LOD}$ \\
\hline RR2 & ND & ND & 0,33 & $<L O Q$ & 2,95 & ND & ND & ND & ND & 0,41 & ND & ND & ND & ND & ND & ND & ND & ND & $<L O D$ \\
\hline RA3 & $<L O Q$ & 0,09 & 1,83 & ND & 2,56 & ND & $<L O D$ & ND & ND & 0,17 & ND & 3,05 & $<L O D$ & 1,87 & $<L O Q$ & 0,75 & $<L O Q$ & $<L O D$ & $<L O Q$ \\
\hline RL3 & ND & ND & ND & ND & ND & ND & ND & ND & ND & ND & ND & ND & ND & ND & ND & ND & ND & ND & ND \\
\hline RR3 & ND & ND & 0,79 & ND & ND & ND & ND & ND & ND & 0,24 & ND & ND & ND & ND & ND & ND & ND & ND & ND \\
\hline RA4 & 1,61 & 0,90 & 12,36 & 0,28 & 4,46 & $<L O D$ & ND & $<L O D$ & ND & 2,22 & ND & ND & 21,88 & 0,83 & 1,01 & 1,19 & ND & 61,75 & 1,23 \\
\hline RL4 & $<L O D$ & ND & 1,12 & ND & 0,80 & ND & $<L O D$ & ND & ND & ND & ND & ND & ND & ND & ND & ND & ND & ND & ND \\
\hline RR4 & ND & ND & ND & ND & ND & ND & ND & ND & ND & $<L O D$ & ND & ND & ND & ND & ND & ND & ND & ND & ND \\
\hline RA5 & $<L O D$ & ND & 0,38 & $<L O Q$ & ND & ND & $<L O D$ & ND & ND & ND & ND & $<L O D$ & $<L O D$ & ND & ND & $<L O D$ & ND & $<L O D$ & $<L O D$ \\
\hline RL5 & $<L O D$ & ND & 0,39 & ND & ND & ND & 0,64 & ND & ND & ND & $<L O D$ & $<$ LOD & ND & $<L O Q$ & ND & ND & ND & ND & ND \\
\hline RR5 & ND & ND & $<L O Q$ & ND & ND & ND & ND & ND & ND & ND & ND & ND & ND & ND & ND & ND & ND & ND & ND \\
\hline
\end{tabular}

${ }^{1}$ As abreviaturas constam no início deste trabalho, na lista de abreviaturas. 
Tabela 20: Concentrações de pesticidas organoclorados encontradas em amostras de raízes de mangues do complexo estuarino de Cananéia1.

Concentração de compostos organoclorados em amostras de raízes de mangues $\left(\mathrm{ngg}^{-1}\right)$

\begin{tabular}{|c|c|c|c|c|c|c|c|c|c|c|c|c|c|c|c|c|c|c|c|}
\hline $\begin{array}{l}\frac{\pi}{5} \\
\frac{0}{0} \\
\frac{1}{4}\end{array}$ & $\begin{array}{l}\frac{T}{0} \\
\frac{1}{d}\end{array}$ & $\begin{array}{l}\text { I } \\
\text { T⿱亠𧘇 } \\
\dot{b}\end{array}$ & $\begin{array}{l}\frac{T}{U} \\
\frac{1}{d}\end{array}$ & $\begin{array}{l}T \\
\frac{1}{1} \\
\dot{1}\end{array}$ & $\begin{array}{l}\text { 은 } \\
\frac{0}{0} \\
\frac{\pi}{0} \\
\frac{0}{0} \\
\frac{1}{1}\end{array}$ & 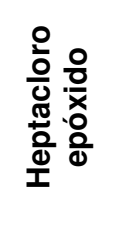 & 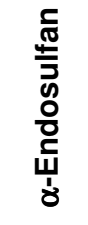 & 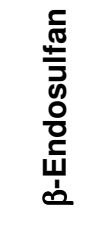 & 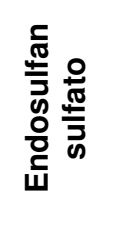 & $\frac{\mathfrak{n}}{\frac{0}{\alpha}}$ & $\frac{\text { 든 }}{\frac{0}{0}}$ & 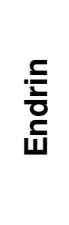 & 돈응 & 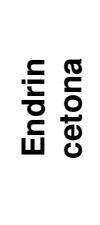 & $\begin{array}{l}0 \\
\frac{0}{0} \\
\frac{2}{2}\end{array}$ & 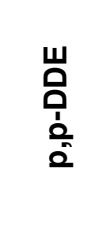 & 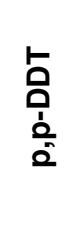 & 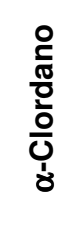 & 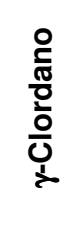 \\
\hline CRA1 & $<L O D$ & ND & ND & ND & $<$ LOD & ND & ND & 3,99 & $<L O D$ & ND & ND & ND & ND & 3,02 & ND & ND & ND & ND & ND \\
\hline CRL1 & 1,25 & ND & ND & ND & ND & ND & ND & ND & ND & ND & ND & ND & ND & ND & ND & ND & ND & ND & ND \\
\hline CRR1 & ND & ND & ND & ND & ND & ND & ND & ND & ND & $<L O D$ & ND & ND & ND & ND & ND & ND & ND & ND & ND \\
\hline CRA2 & ND & ND & ND & ND & ND & ND & ND & ND & ND & ND & ND & ND & ND & $<L O Q$ & ND & ND & ND & ND & ND \\
\hline CRL2 & 0,53 & ND & ND & ND & ND & ND & 0,74 & $<L O D$ & ND & ND & ND & ND & ND & ND & ND & $<L O Q$ & ND & ND & ND \\
\hline CRR2 & ND & 0,26 & ND & ND & ND & ND & $\mathrm{ND}$ & ND & ND & ND & ND & ND & ND & ND & ND & ND & ND & ND & ND \\
\hline CRA3 & ND & ND & ND & ND & ND & ND & ND & ND & ND & ND & ND & ND & ND & ND & ND & ND & ND & ND & ND \\
\hline CRL3 & ND & ND & ND & ND & ND & ND & ND & ND & ND & ND & ND & ND & 1,41 & ND & ND & ND & ND & ND & ND \\
\hline CRR3 & $<L O D$ & 0,74 & ND & ND & $<L O Q$ & ND & ND & ND & ND & $<L O D$ & ND & ND & ND & ND & ND & ND & ND & ND & ND \\
\hline CRL4 & ND & ND & ND & ND & ND & ND & ND & $<L O D$ & ND & ND & ND & ND & ND & ND & ND & ND & ND & ND & ND \\
\hline CRR4 & ND & ND & ND & ND & ND & ND & ND & ND & ND & 0,84 & ND & ND & ND & ND & ND & ND & ND & ND & ND \\
\hline CRA5 & ND & ND & ND & ND & ND & ND & ND & ND & ND & ND & ND & ND & ND & ND & ND & ND & ND & ND & ND \\
\hline CRL5 & ND & ND & ND & ND & ND & ND & ND & ND & ND & ND & ND & ND & ND & ND & ND & ND & ND & ND & ND \\
\hline CRR5 & ND & ND & ND & ND & ND & $<L O D$ & $\mathrm{ND}$ & ND & ND & ND & ND & ND & ND & ND & ND & ND & ND & ND & ND \\
\hline
\end{tabular}

${ }^{1}$ As abreviaturas constam no início deste trabalho, na lista de abreviaturas. 
Analisando os gráficos de comparação entre as concentrações de organoclorados nas amostras de sedimento para os diferentes pontos de coleta nas duas regiões de estudo (Figuras 58 e 59), foi possível observar que de uma forma geral, exceto em alguns casos, os resultados obtidos correspondem ao comportamento da OM e CEC, conforme o esperado.

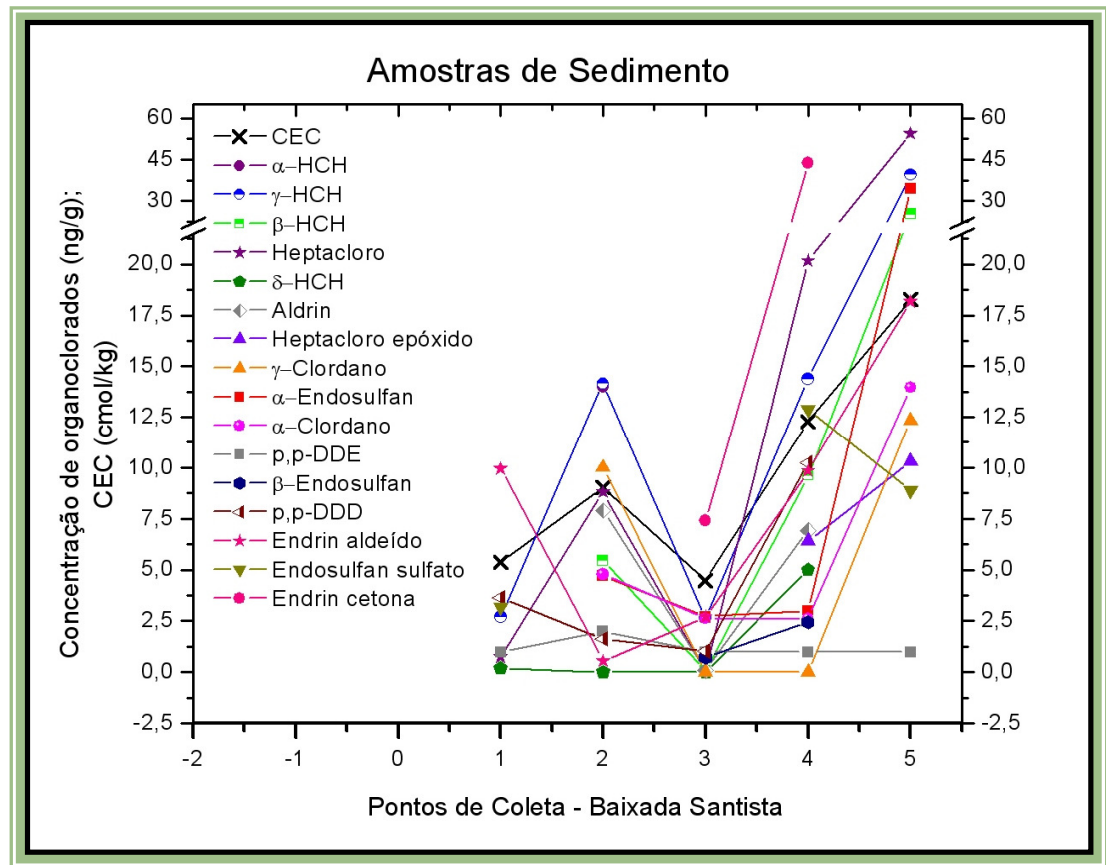

Figura 58: Gráfico de comparação das concentrações de organoclorados em amostras de sedimento em cinco pontos de coleta do complexo estuarino da Baixada Santista.

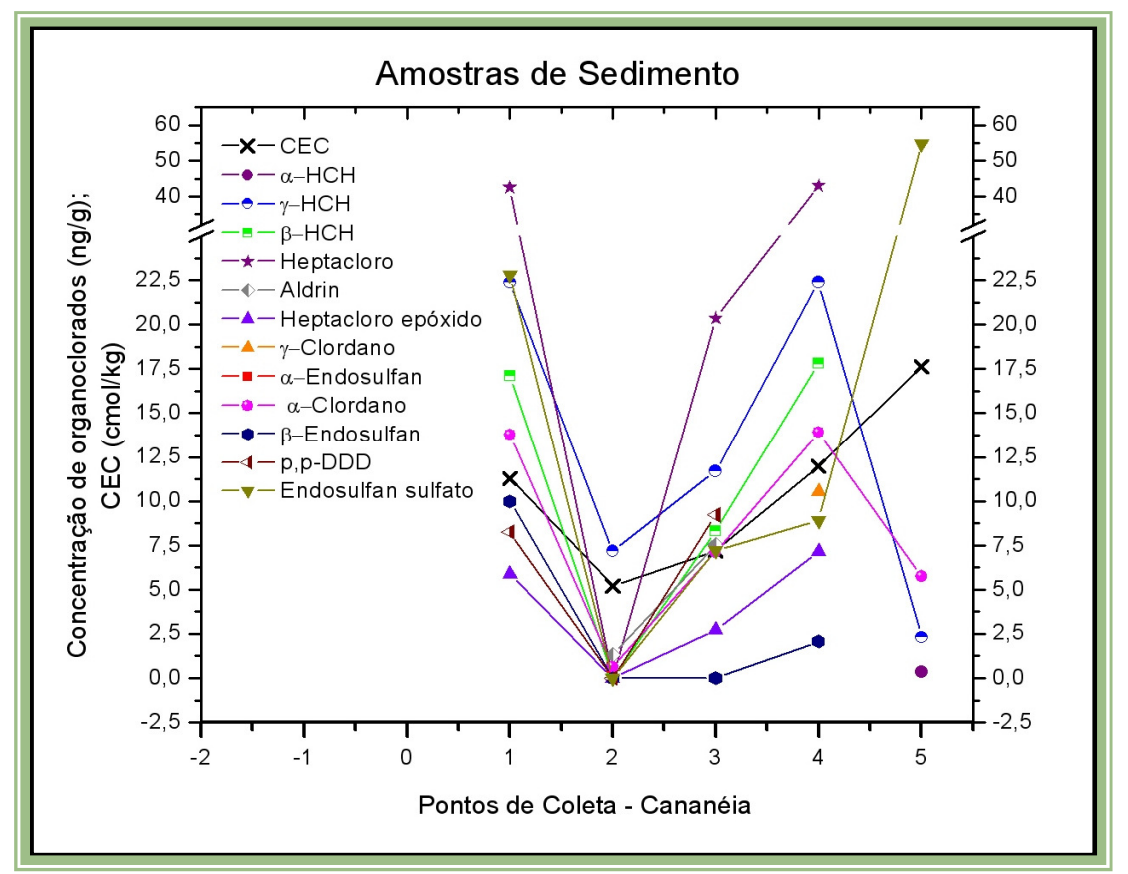

Figura 59: Gráfico de comparação das concentrações de organoclorados em amostras de sedimento em cinco pontos de coleta do complexo estuarino de Cananéia. 
Nas amostras de folhas e raízes de mangue, apenas alguns compostos apresentaram comportamento semelhante enquanto que outros se mostraram ausentes (figuras 60 a 71), embora não seja uma regra.

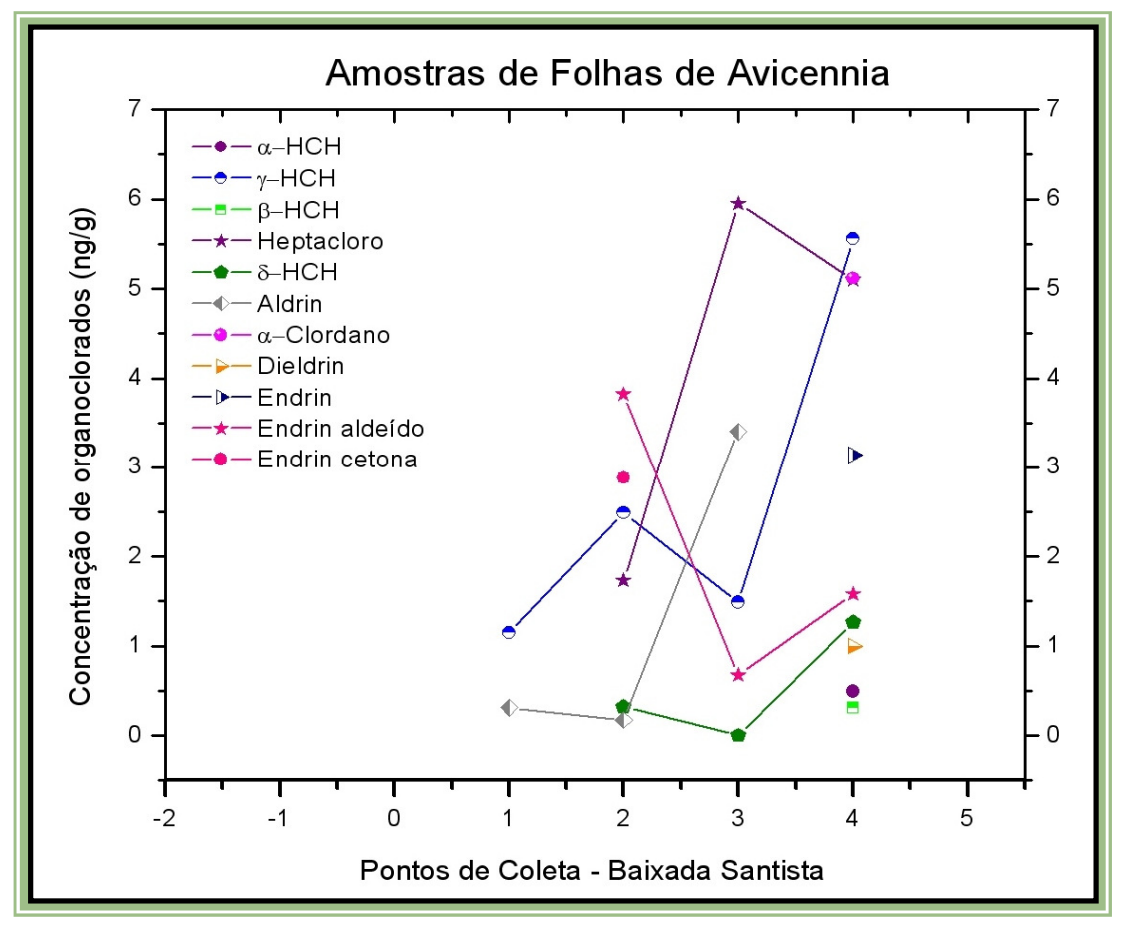

Figura 60: Gráfico de comparação das concentrações de organoclorados em amostras de folhas de Avicennia schaueriana (mangue preto) em cinco pontos de coleta do complexo estuarino da Baixada Santista.

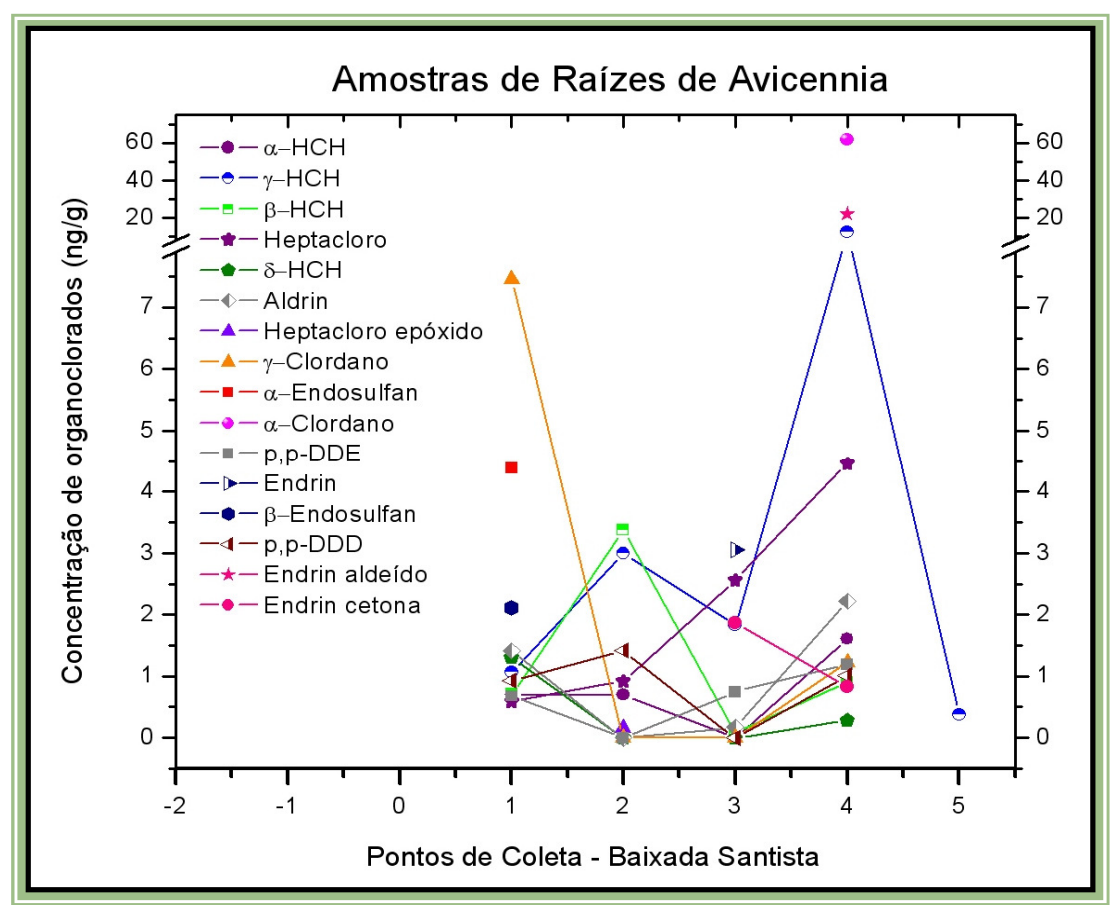

Figura 61: Gráfico de comparação das concentrações de organoclorados em amostras de raízes de Avicennia schaueriana (mangue preto) em cinco pontos de coleta do complexo estuarino da Baixada Santista. 


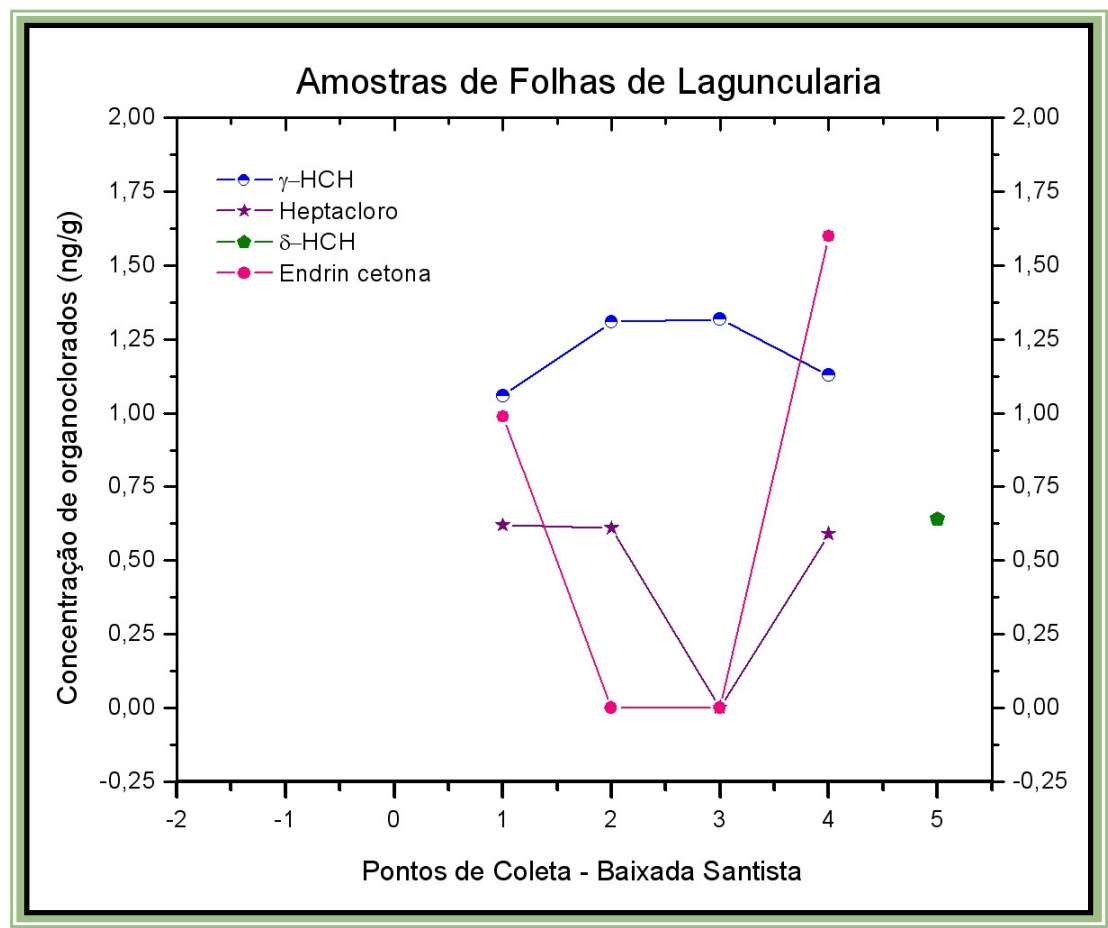

Figura 62: Gráfico de comparação das concentrações de organoclorados em amostras de folhas de Laguncularia racemosa (mangue branco) em cinco pontos de coleta do complexo estuarino da Baixada Santista.

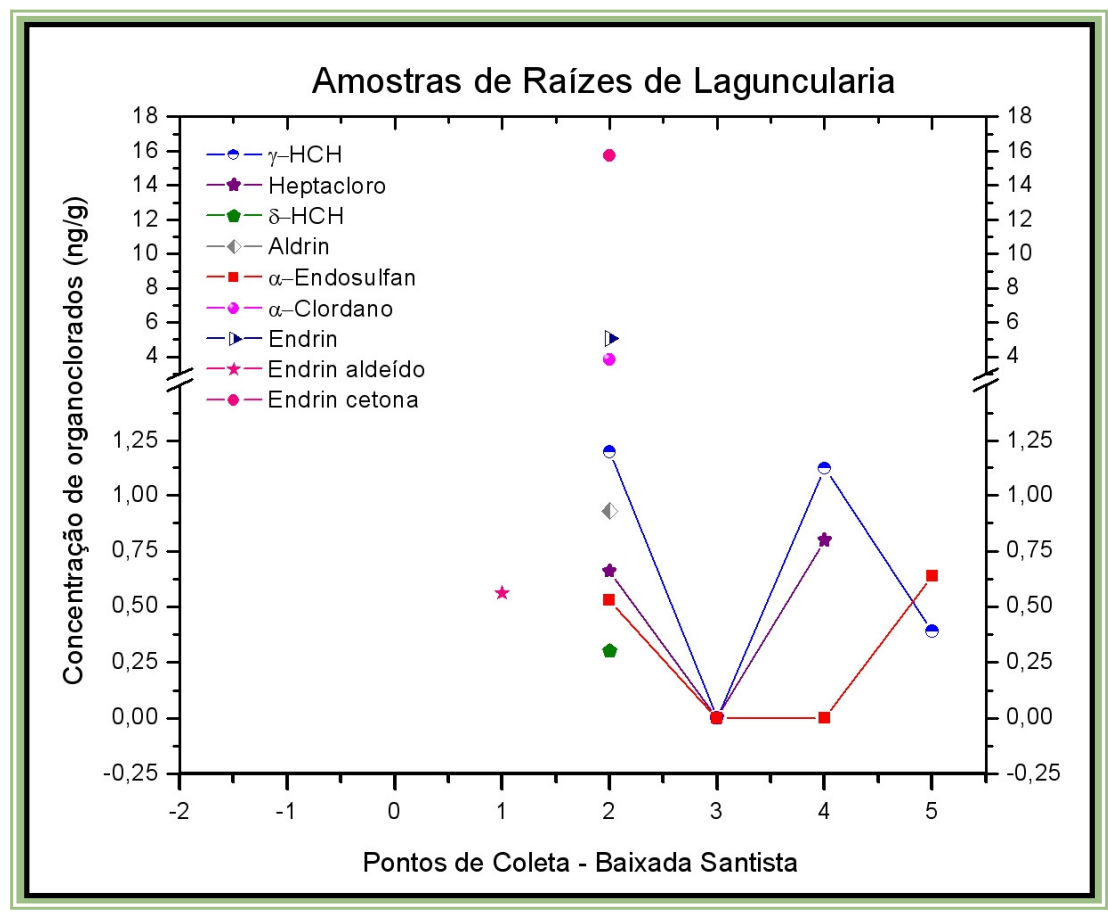

Figura 63: Gráfico de comparação das concentrações de organoclorados em amostras de raízes de Laguncularia racemosa (mangue branco) em cinco pontos de coleta do complexo estuarino da Baixada Santista. 


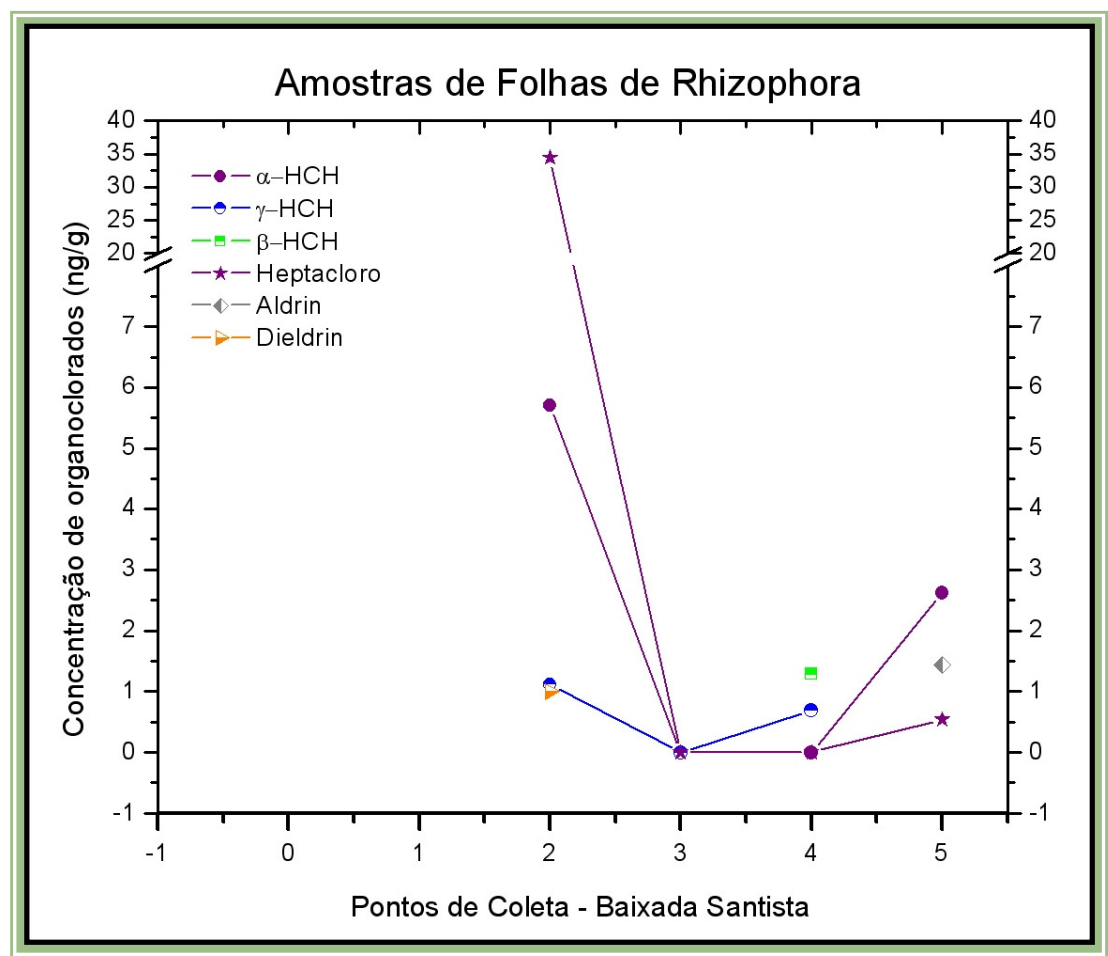

Figura 64: Gráfico de comparação das concentrações de organoclorados em amostras de folhas de Rhizophora mangle (mangue vermelho) em quatro pontos de coleta do complexo estuarino da Baixada Santista.

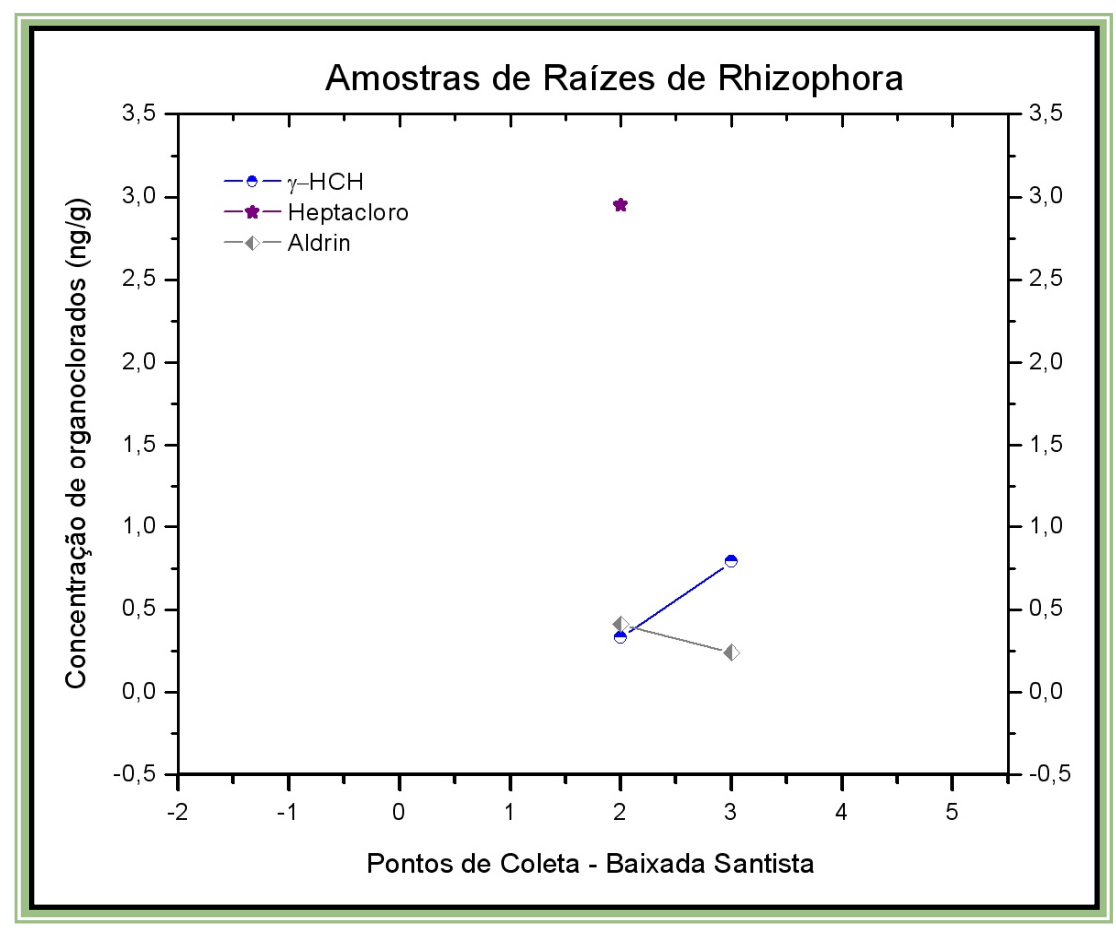

Figura 65: Gráfico de comparação das concentrações de organoclorados em amostras de raízes de Rhizophora mangle (mangue vermelho) em quatro pontos de coleta do complexo estuarino da Baixada Santista. 


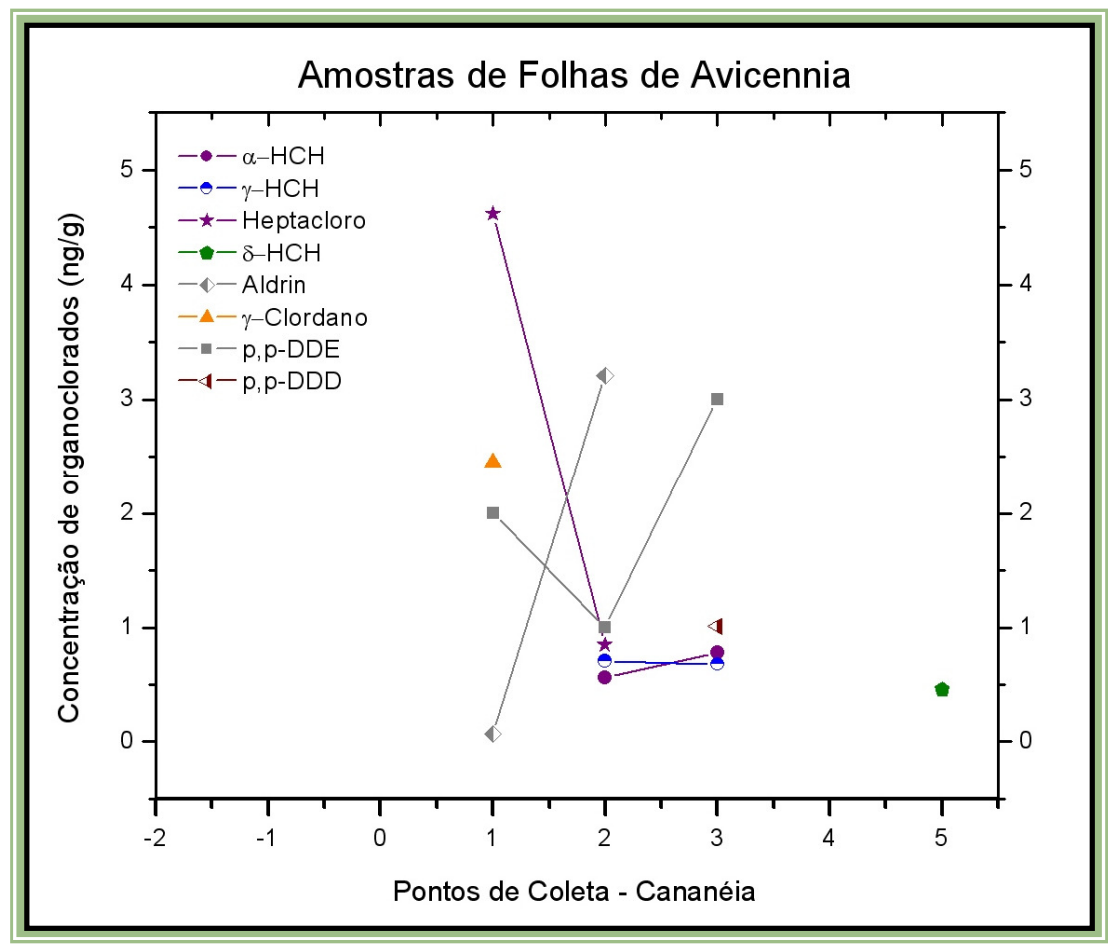

Figura 66: Gráfico de comparação das concentrações de organoclorados em amostras de folhas de Avicennia schaueriana (mangue preto) em quatro pontos de coleta do complexo estuarino de Cananéia.

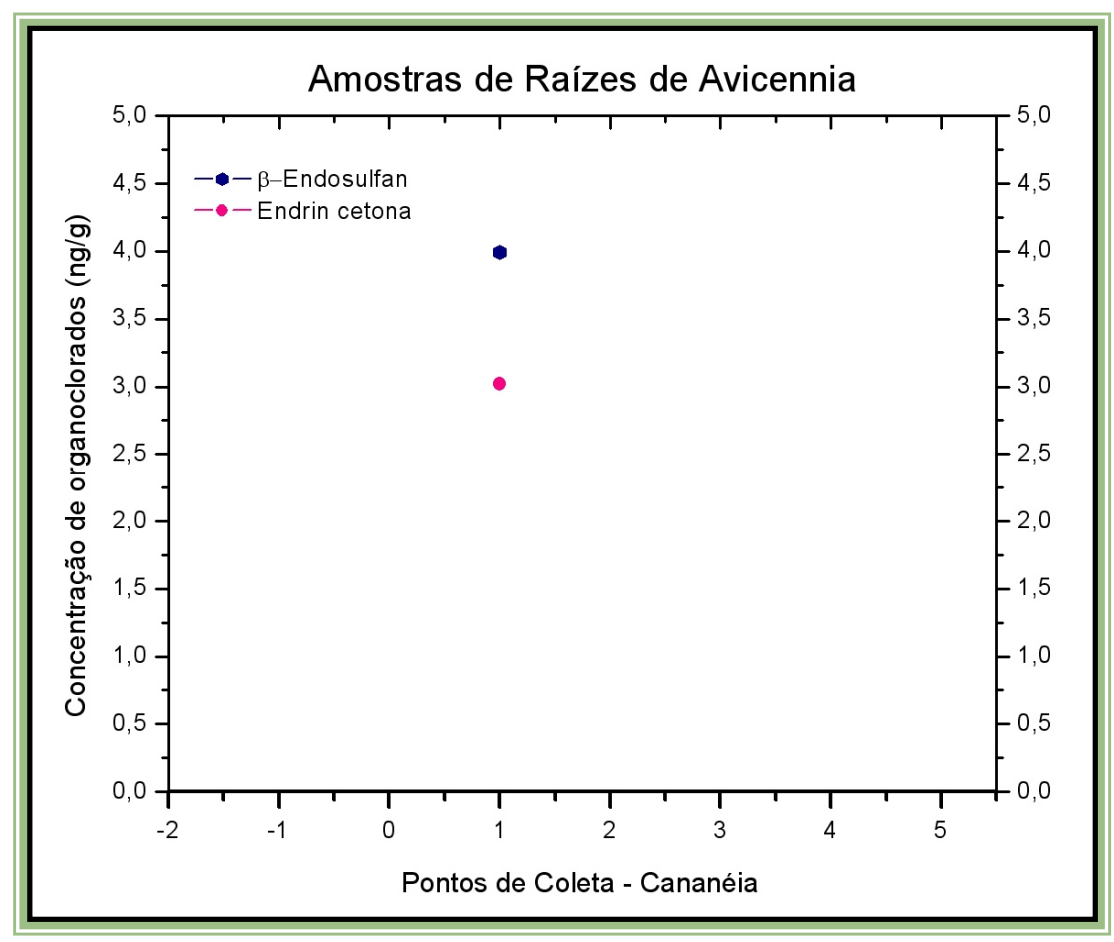

Figura 67: Gráfico de comparação das concentrações de organoclorados em amostras de raízes de Avicennia schaueriana (mangue preto) em quatro pontos de coleta do complexo estuarino de Cananéia. 


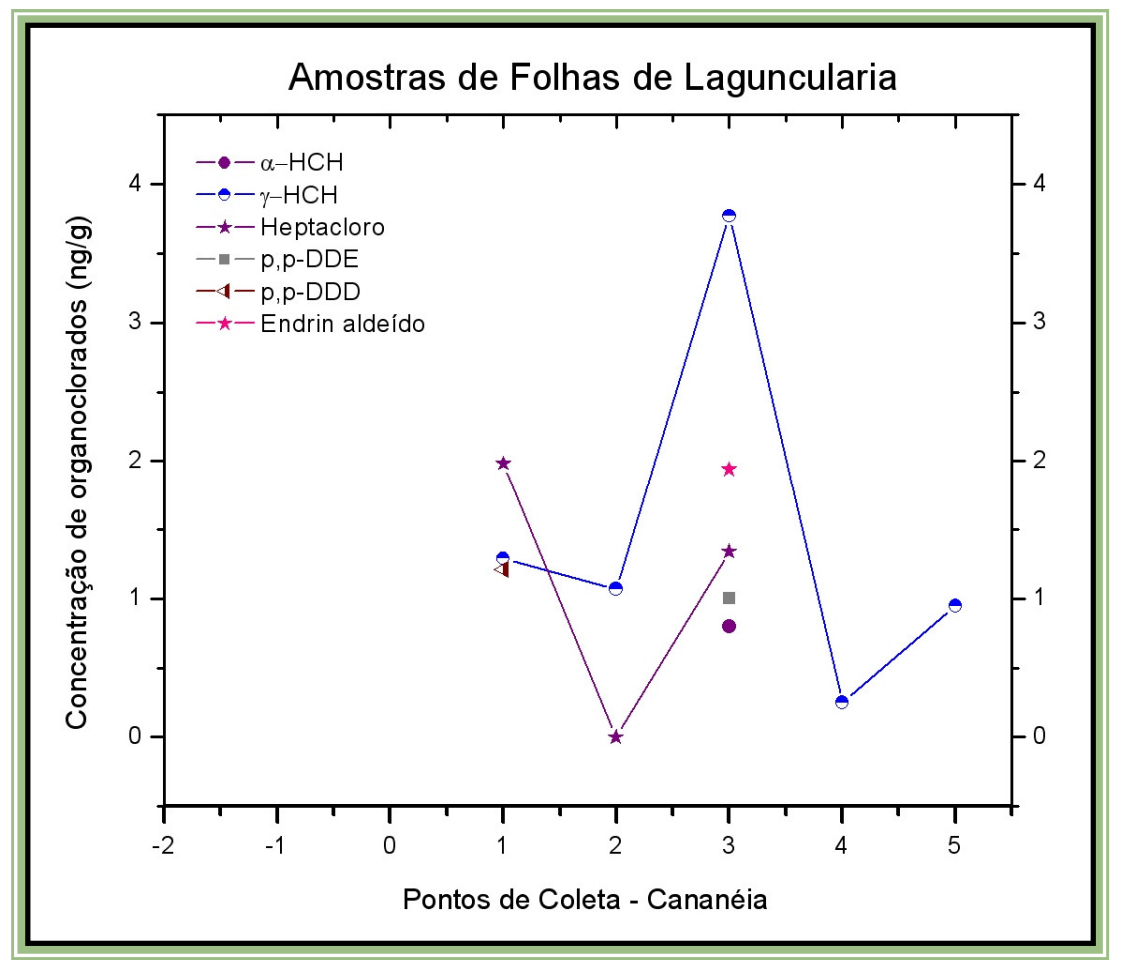

Figura 68: Gráfico de comparação das concentrações de organoclorados em amostras de folhas de Laguncularia racemosa (mangue branco) em cinco pontos de coleta do complexo estuarino de Cananéia.

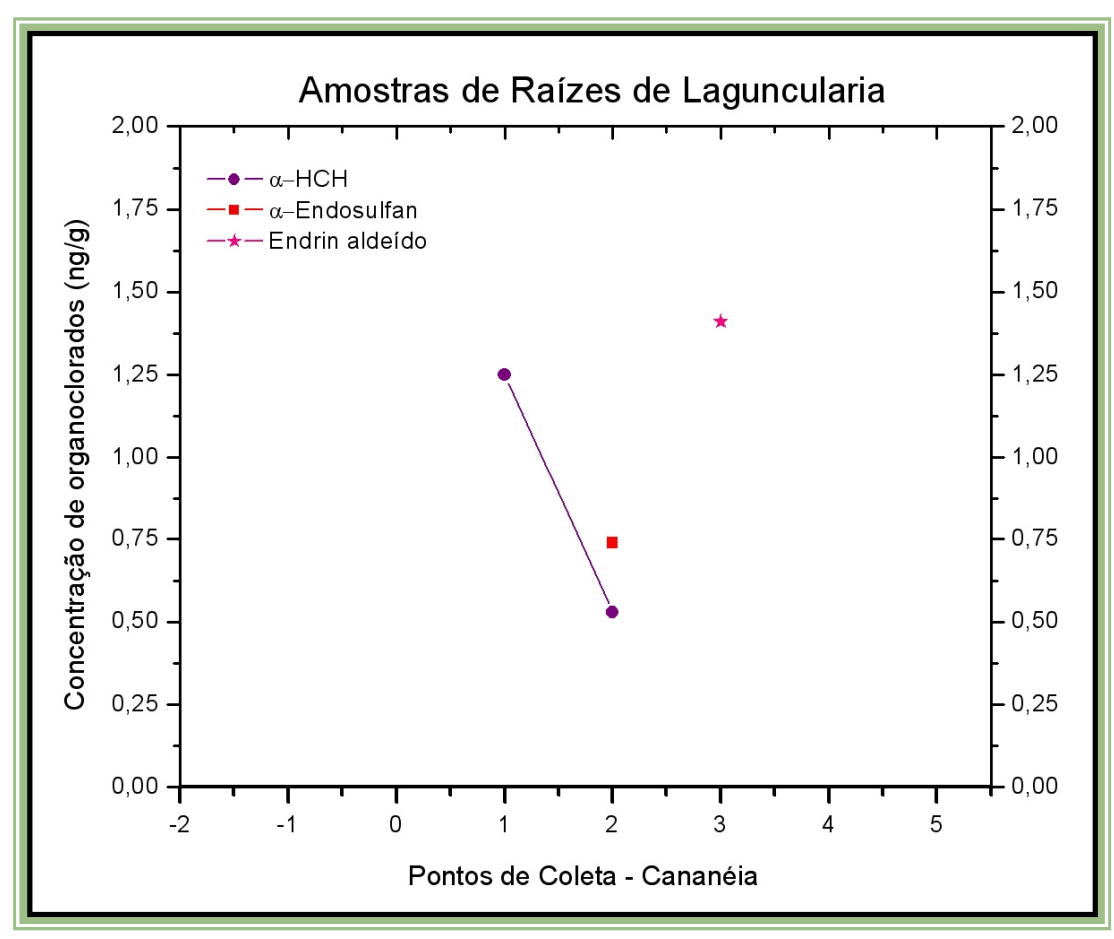

Figura 69: Gráfico de comparação das concentrações de organoclorados em amostras de raízes de Laguncularia racemosa (mangue branco) em cinco pontos de coleta do complexo estuarino de Cananéia. 


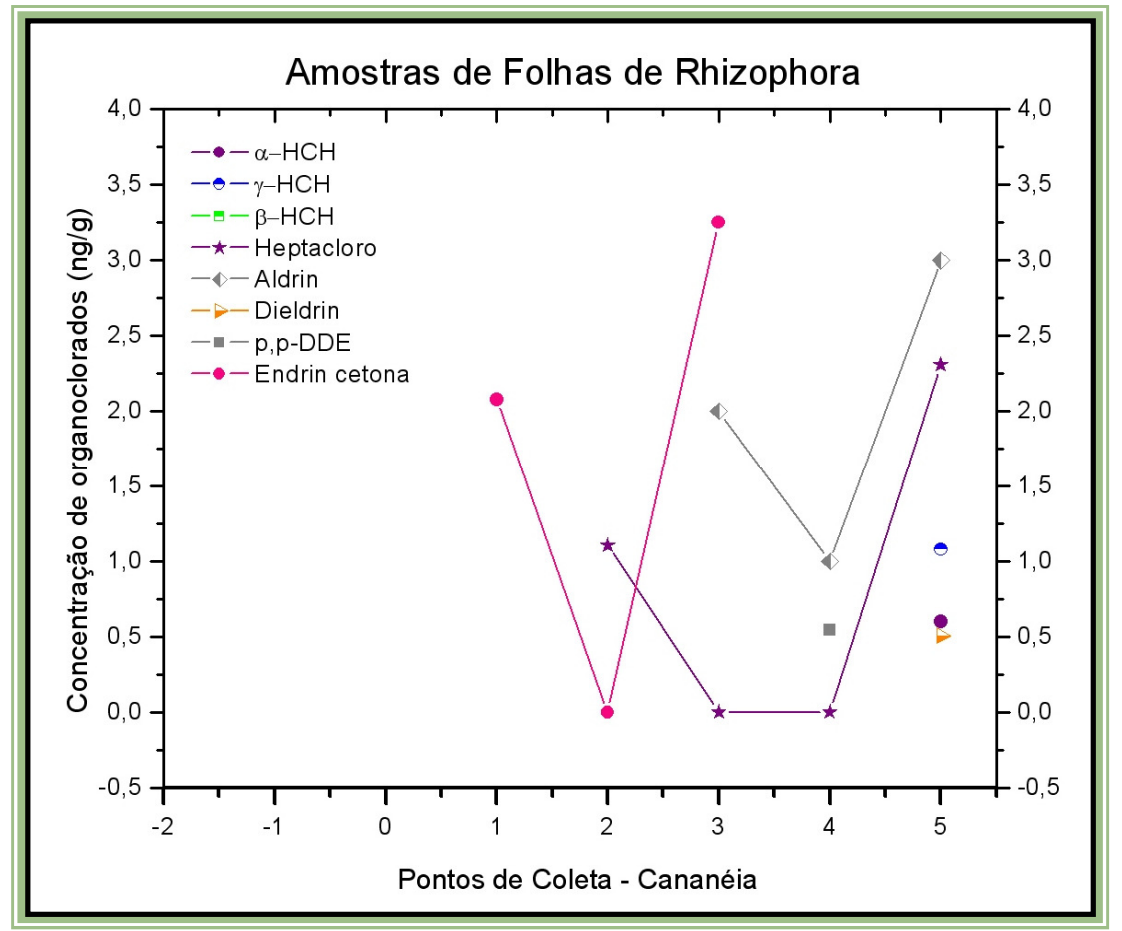

Figura 70: Gráfico de comparação das concentrações de organoclorados em amostras de folhas de Rhizophora mangle (mangue vermelho) em cinco pontos de coleta do complexo estuarino de Cananéia.

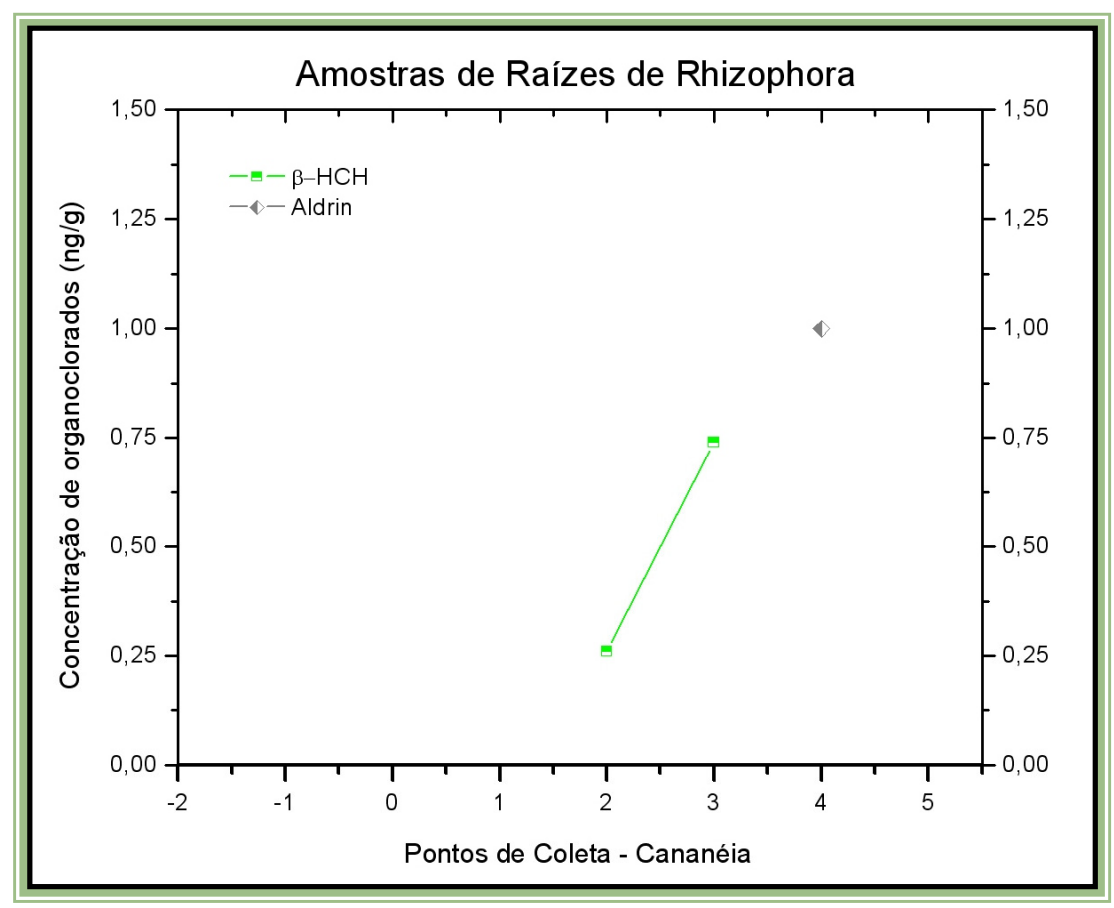

Figura 71: Gráfico de comparação das concentrações de organoclorados em amostras de raízes de Rhizophora mangle (mangue vermelho) em cinco pontos de coleta do complexo estuarino de Cananéia. 
Em seguida são demonstrados os gráficos que relacionam diferentes matrizes em um mesmo ponto de coleta para as duas regiões. No ponto $1 \mathrm{da}$ Baixada Santista (figura 72) pode ser observado maior variedade de compostos nas raízes da espécie Avicennia schaueriana em comparação com 0 sedimento, o que pode ser um indicativo de que estes compostos estão neste local há um tempo relativamente longo.

No ponto 2 da Baixada Santista as concentrações de $\alpha-\mathrm{HCH}$ e $\gamma-\mathrm{HCH}$ são similares enquanto que o $\beta-\mathrm{HCH}$ é aproximadamente a metade, porém isto pode ser devido aos valores de recuperação. Ainda no ponto 2, o endrin cetona destaca-se frente ao endrin aldeído nas raízes de Laguncularia racemosa enquanto que ocorre o oposto nas folhas de Avicennia schaueriana. Estas curiosidades ocorrem em quase todos os pontos de uma maneira ou outra, pois verificando resultados para os diferentes compostos nas diferentes matrizes foi possível perceber a dificuldade de se estabelecer regras.

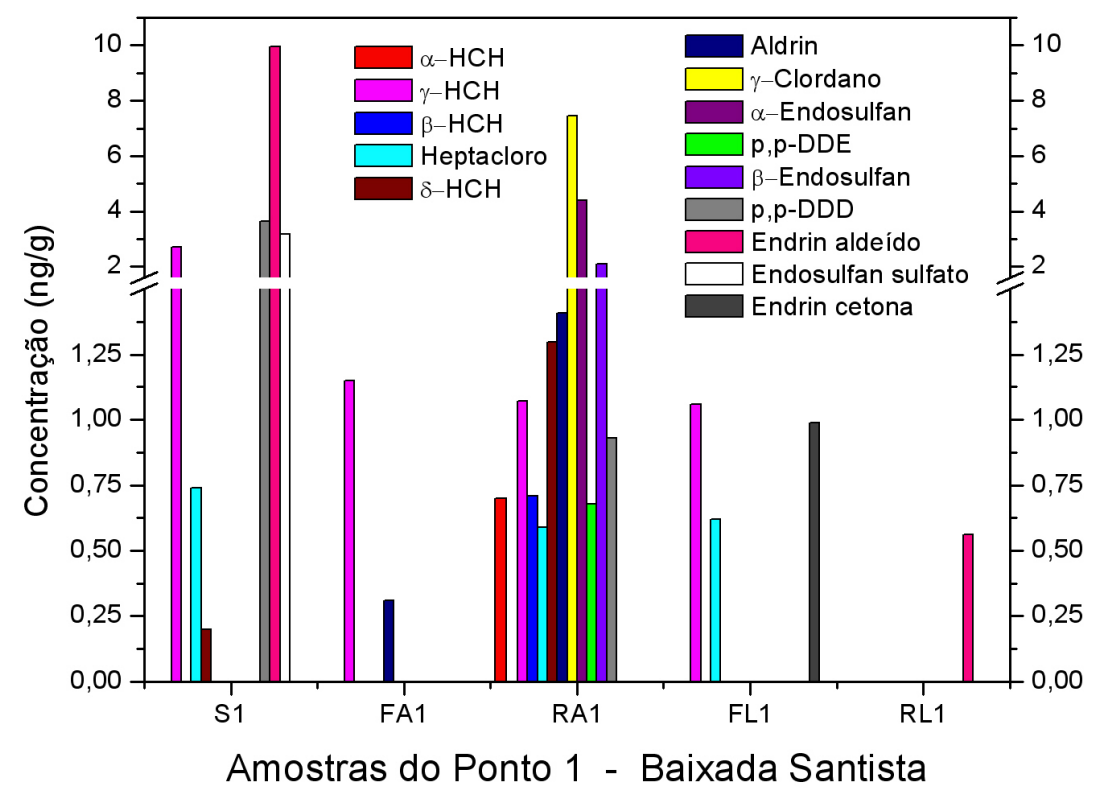

Figura 72: Gráfico de comparação das concentrações de organoclorados em diferentes matrizes do ponto 1 do complexo estuarino da Baixada Santista. 


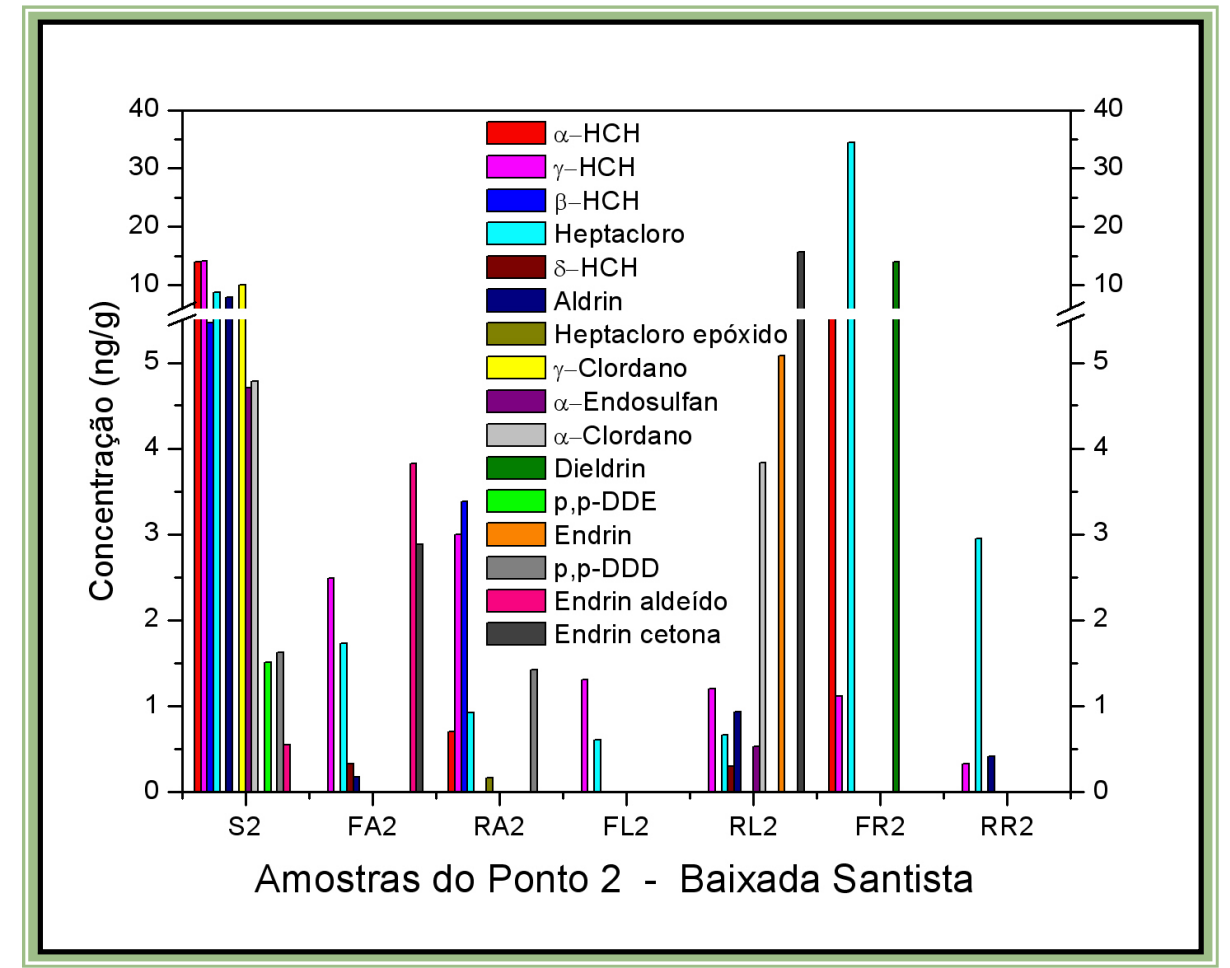

Figura 73: Gráfico de comparação das concentrações de organoclorados em diferentes matrizes do ponto 2 do complexo estuarino da Baixada Santista.

No ponto 3 da Baixada Santista (figura 74), observou-se a ausência de compostos organoclorados nas raízes de Laguncularia enquanto que as folhas desta mesma espécie contém o $\gamma-\mathrm{HCH}$. Já para a espécie Rhizophora ocorre o oposto, onde são as folhas que se apresentam isentas destes compostos. Neste mesmo ponto pode ser observado que a espécie Avicennia apresentou maior quantidade dos pesticidas em relação às outras espécies, assim como ocorreu no ponto 1 e no ponto 4 (Figuras 72 e 75). Nos pontos 4 e 5 , as aleatoriamente são mantidas e os gráficos são mostrados a seguir.

Nas amostras de Cananéia nos pontos 1, 3 e 4, os compostos organoclorados se mostraram mais presentes nos sedimentos, enquanto que no ponto 2 estes foram mais evidentes em folhas de Avicennia, e no ponto 5 predominaram nas amostras de folhas de Rhizophora. De uma maneira geral, as folhas contêm mais pesticidas organoclorados do que suas respectivas raízes, seja qual for a espécie. 


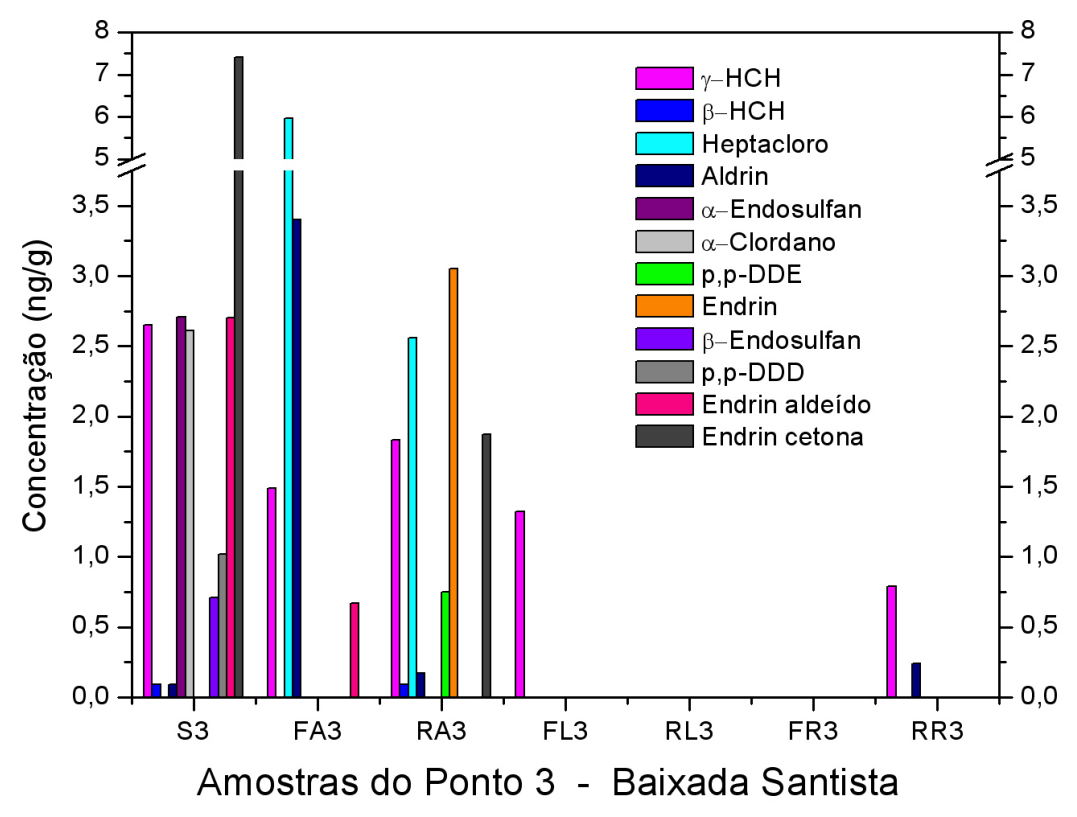

Figura 74: Gráfico de comparação das concentrações de organoclorados em diferentes matrizes do ponto 3 do complexo estuarino da Baixada Santista.

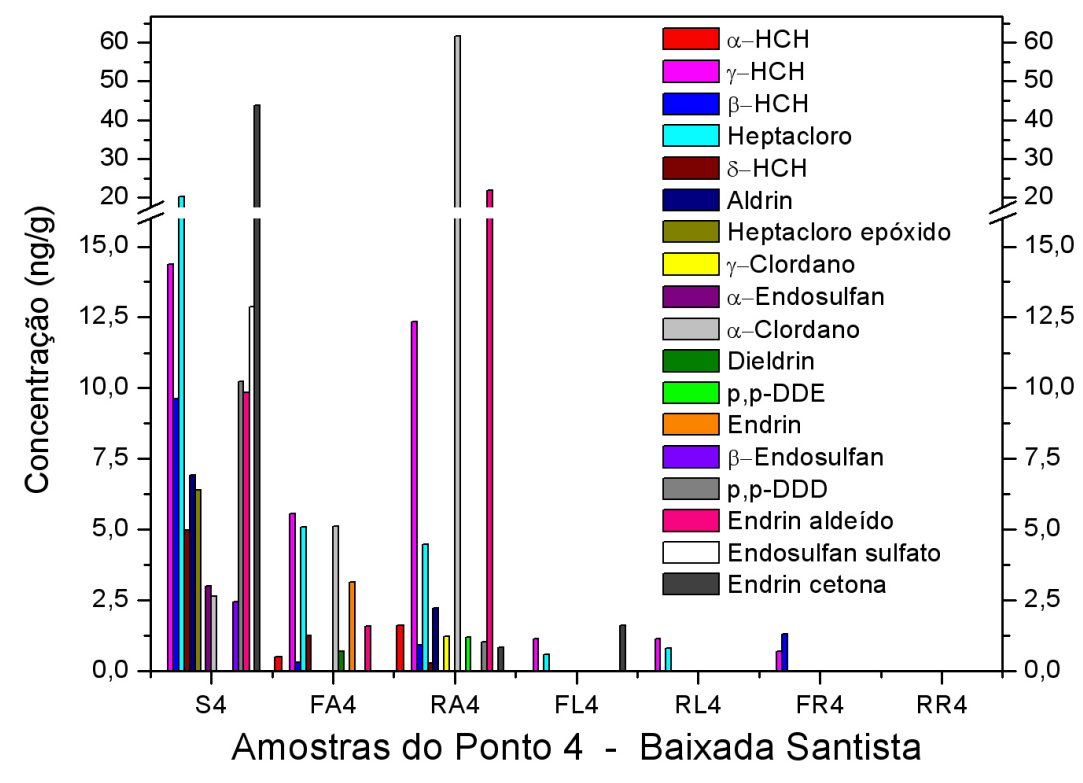

Figura 75: Gráfico de comparação das concentrações de organoclorados em diferentes matrizes do ponto 4 do complexo estuarino da Baixada Santista. 


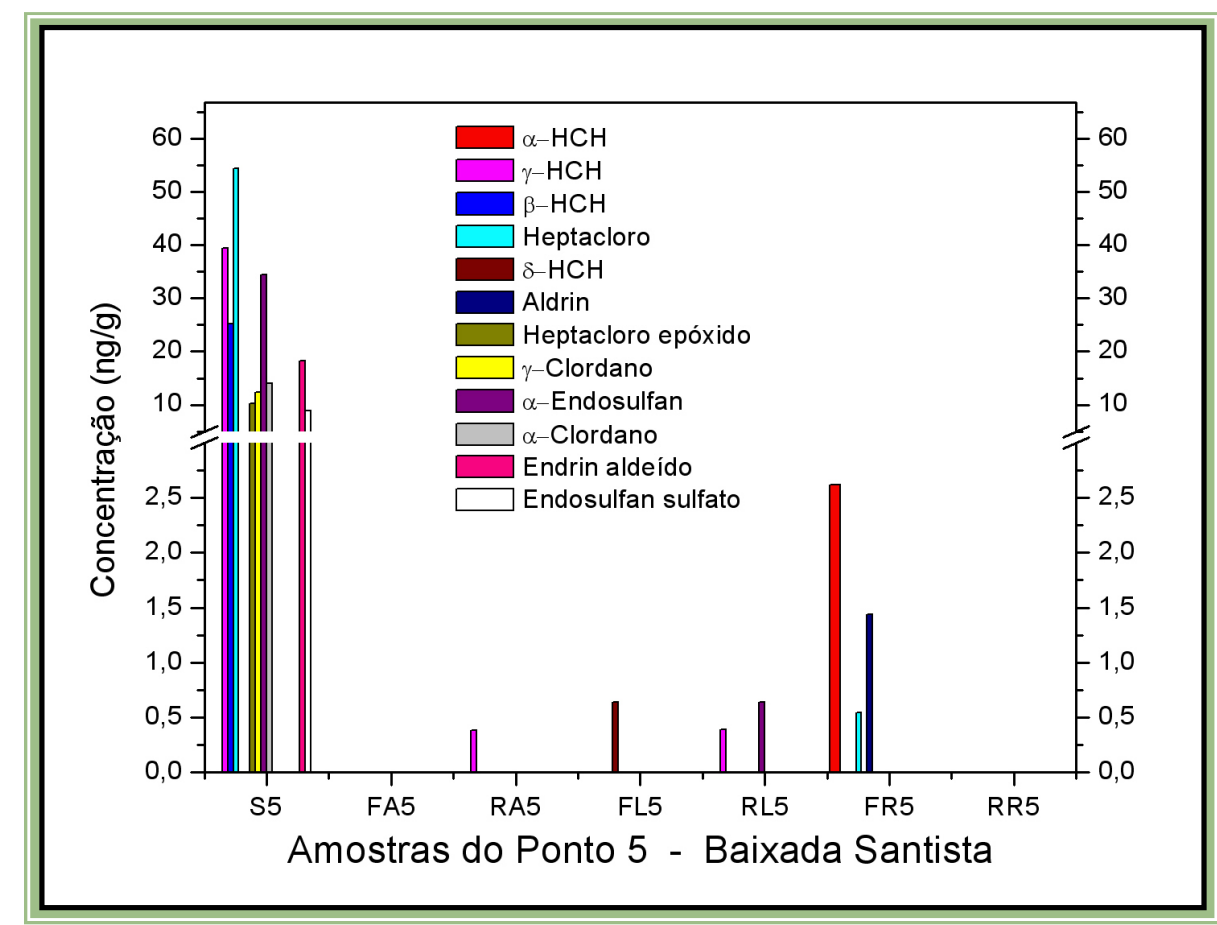

Figura 76: Gráfico de comparação das concentrações de organoclorados em diferentes matrizes do ponto 5 do complexo estuarino da Baixada Santista.

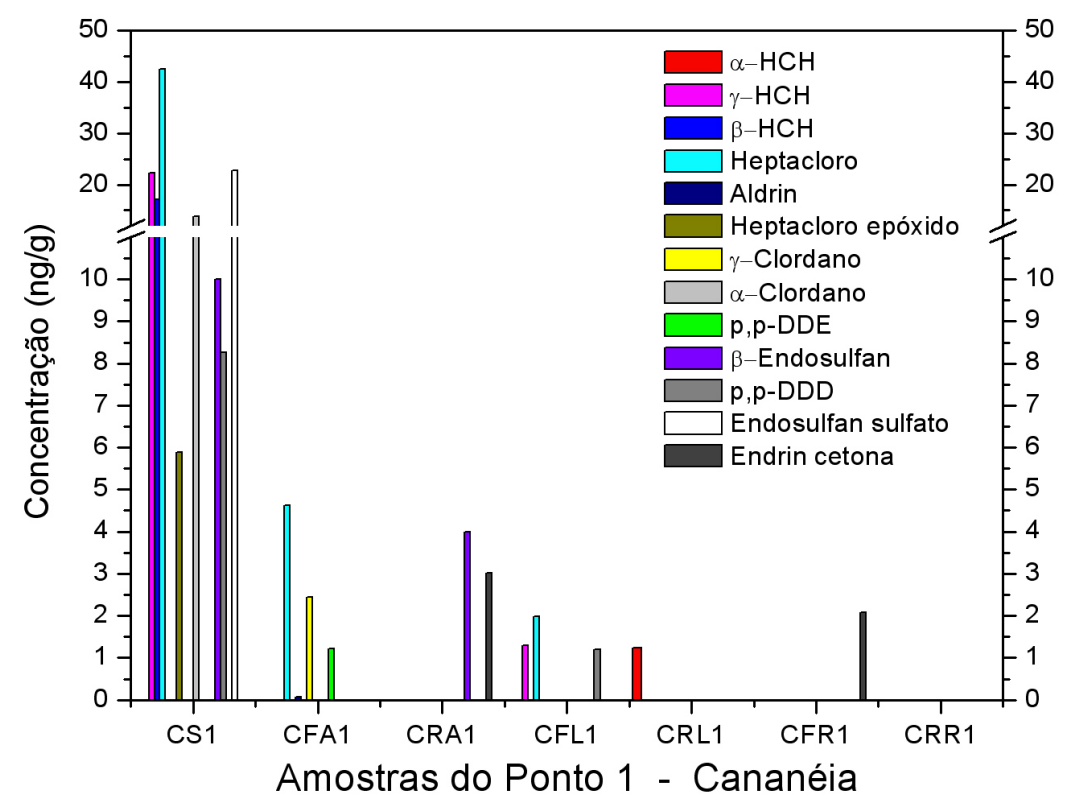

Figura 77: Gráfico de comparação das concentrações de organoclorados em diferentes matrizes do ponto 1 do complexo estuarino de Cananéia. 


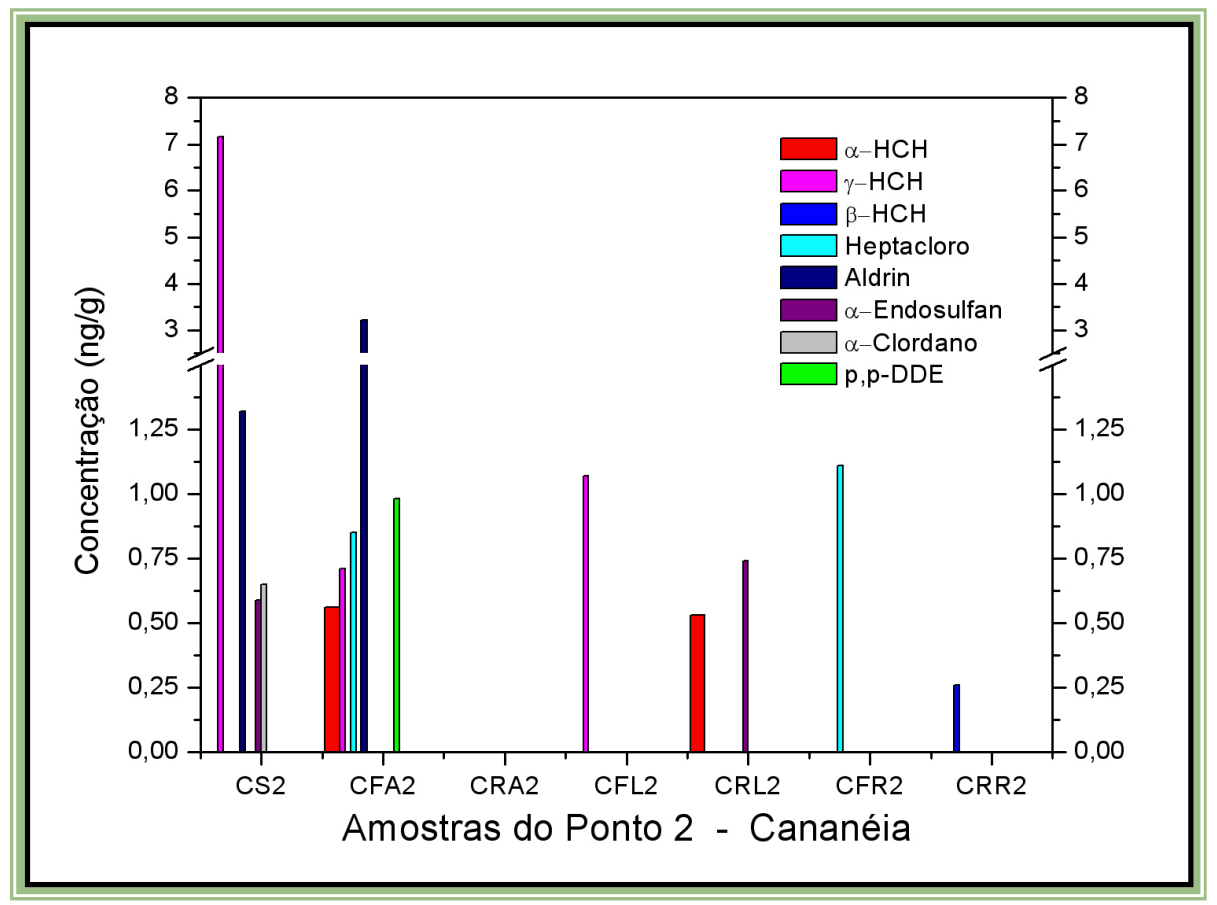

Figura 78: Gráfico de comparação das concentrações de organoclorados em diferentes matrizes do ponto 2 do complexo estuarino de Cananéia.

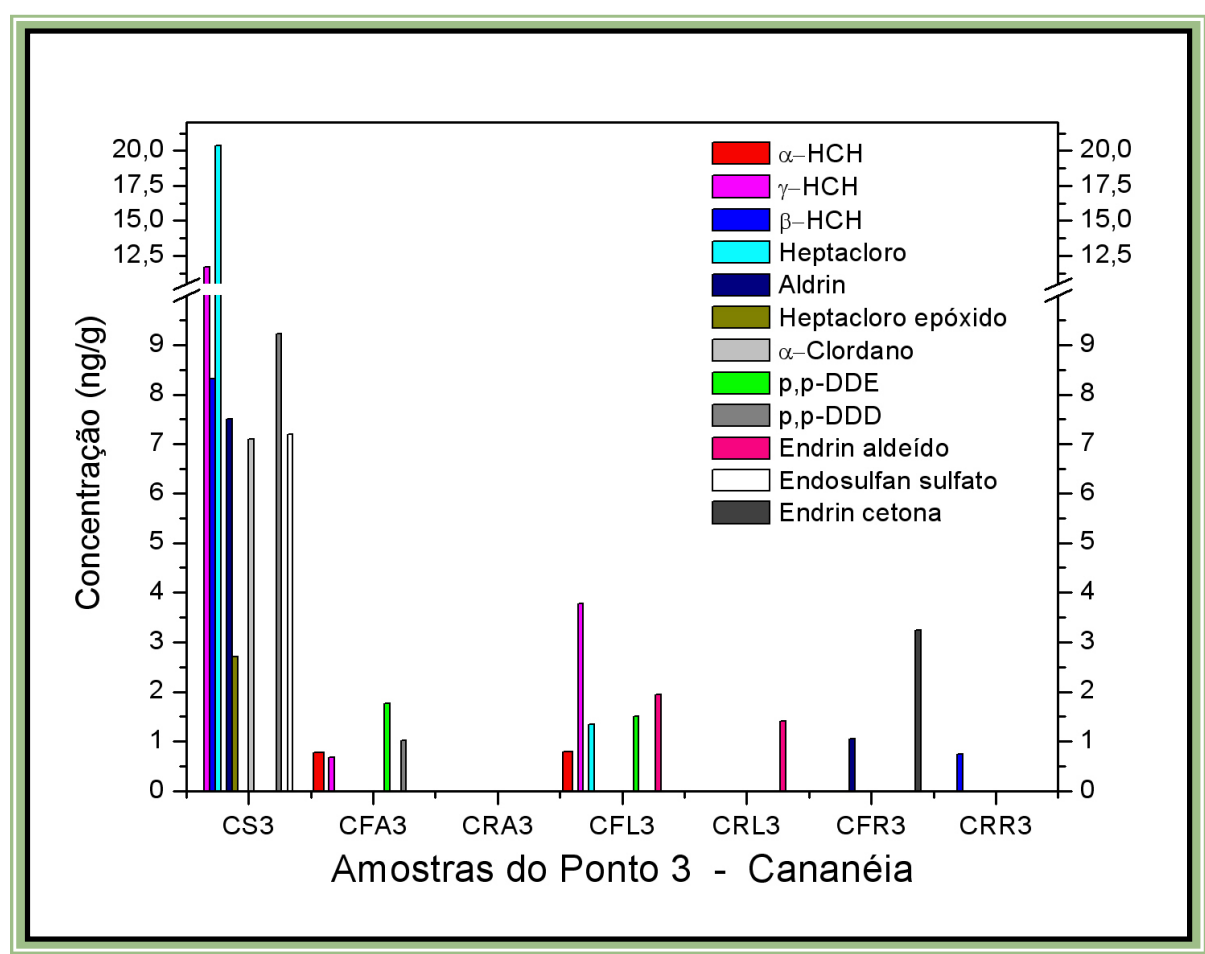

Figura 79: Gráfico de comparação das concentrações de organoclorados em diferentes matrizes do ponto 3 do complexo estuarino de Cananéia. 


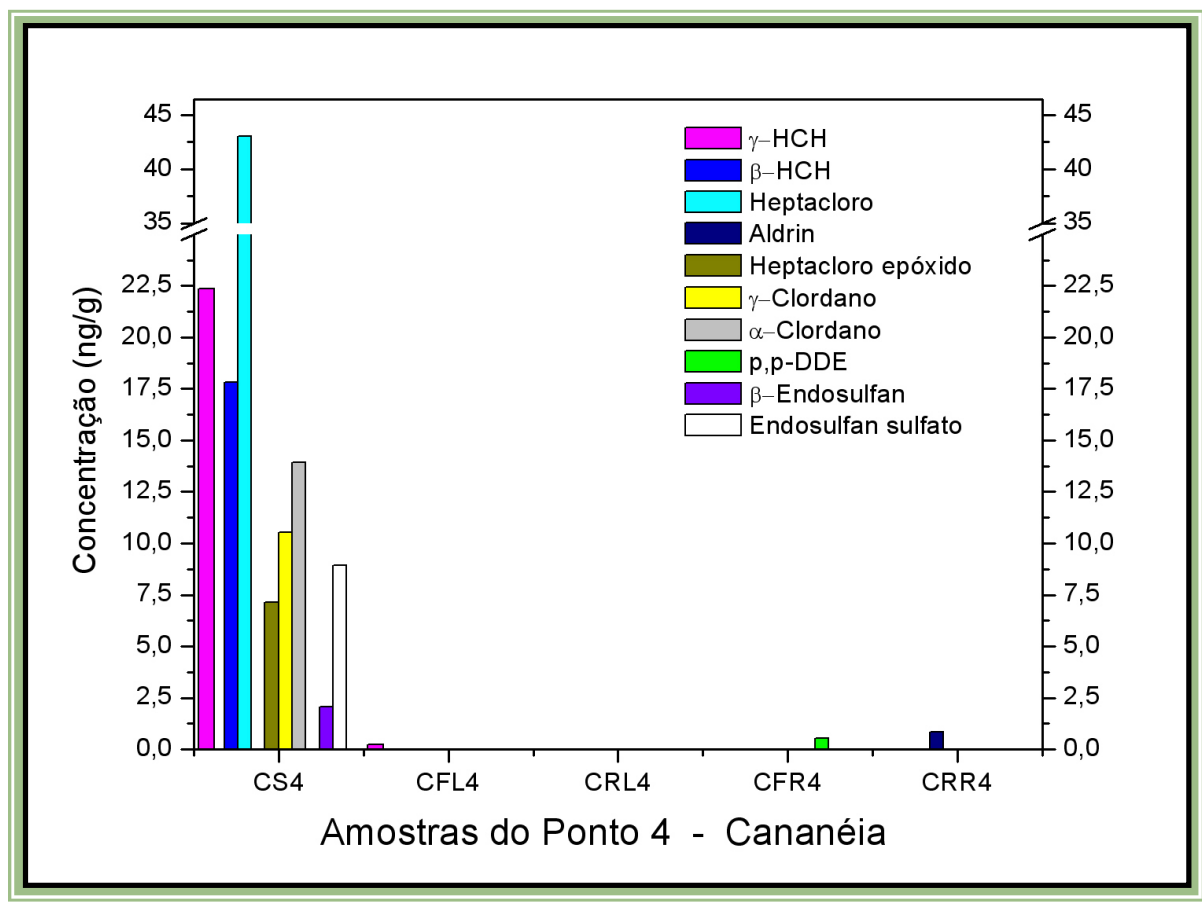

Figura 80: Gráfico de comparação das concentrações de organoclorados em diferentes matrizes do ponto 4 do complexo estuarino de Cananéia.

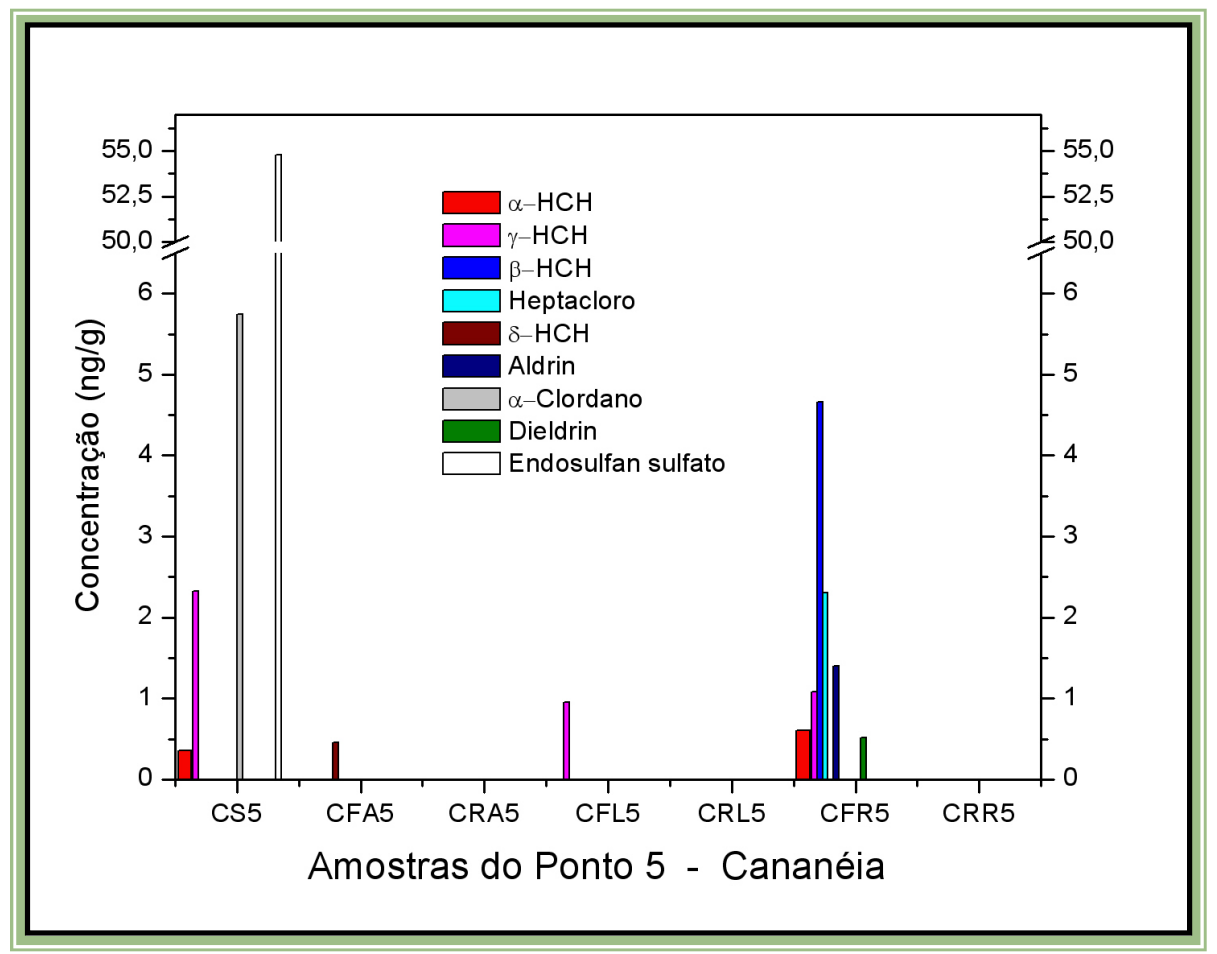

Figura 81: Gráfico de comparação das concentrações de organoclorados em diferentes matrizes do ponto 5 do complexo estuarino de Cananéia. 


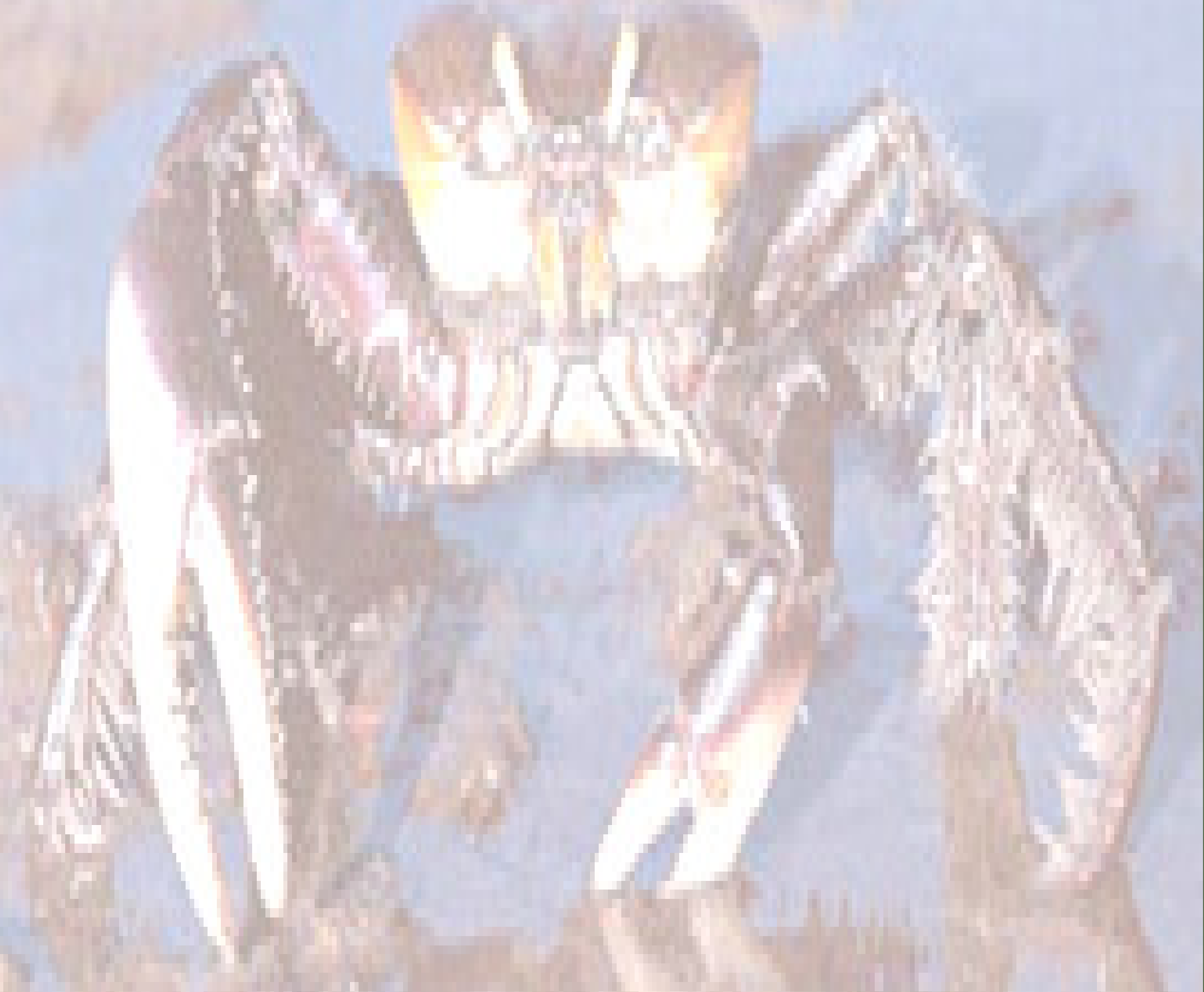

A normalidade é tão somente uma questão de estatística.

Aldous Huxley

\section{Conclusões}




\section{CONCLUSÕES}

Através dos resultados obtidos, foi possível observar que as regiões deste estudo apresentam, a princípio, uma notável diferença entre si, pois os manguezais do complexo estuarino da Baixada Santista são constituídos de uma contradição entre a beleza e a biodiversidade que este ecossistema oferece e a evidente poluição por resíduos sólidos, enquanto que o complexo de Cananéia apresenta um cenário ecológico incomparável.

No entanto, os resultados analíticos obtidos demonstraram que esta diferença não é tão acentuada, uma vez que ambas as regiões apresentaram contaminação por pesticidas organoclorados em quase todos os pontos de coleta. Compostos como o $\gamma-\mathrm{HCH}$, que é altamente tóxico e bioacumulativo, são possíveis carcinogênicos e foram encontrados em altas concentrações. Portanto, é de grande preocupação que ecossistemas como os manguezais e estuários, onde a atividade de pesca é intensa, tenham um maior controle ambiental.

Em relação aos metais, os pontos 3 e 5 da Baixada Santista e o ponto 5 de Cananéia, apresentaram sedimentos com elevadas concentrações de Co, $\mathrm{Pb}$ e $\mathrm{Zn}$. Enquanto que para as amostras de água, os pontos 1 e 3 de Cananéia e o ponto 5 da Baixada Santista também apresentaram valores acima dos limites estabelecidos pelas legislações para os metais $\mathrm{Mn}, \mathrm{Zn}$ e $\mathrm{Cr}$.

Em sua maioria, as concentrações dos analitos estudados apresentaram relações diretas com a matéria orgânica e a capacidade de troca catiônica. Em teoria, por exemplo, os metais $\mathrm{Pb}$ e Cu devem se prender mais em sedimentos através da CEC, o que foi possível observar com os resultados obtidos. Os teores de ácidos húmicos e de carbono orgânico total também se mostraram correlacionados com os outros parâmetros estudados, exceto em algumas amostras.

É importante ressaltar ainda que, além da ausência de limites de tolerância para determinados compostos nas legislações que se referem aos sedimentos e solos, também há uma falta de leis que se apliquem 
especificamente às plantas que formam os manguezais, pois estas são a base alimentar de uma variedade de espécies que por sua vez servem de alimento ao ser humano. Assim, considerando que metais em excesso e pesticidas organoclorados não são naturais em áreas de manguezais e nem mesmo fazem parte da fisiologia de plantas que habitam estes ecossistemas, verificase a necessidade de maior atenção das autoridades responsáveis.

Considerando os resultados obtidos no diagnóstico das áreas de manguezais dos complexos estuarinos da Baixada Santista e de Cananéia, que pôde ser realizado através da determinação de metais e pesticidas organoclorados em amostras de diferentes matrizes, a autora sugere como pesquisa futura, o estudo da bioacumulação destes compostos na cadeia alimentar dos manguezais citados. 


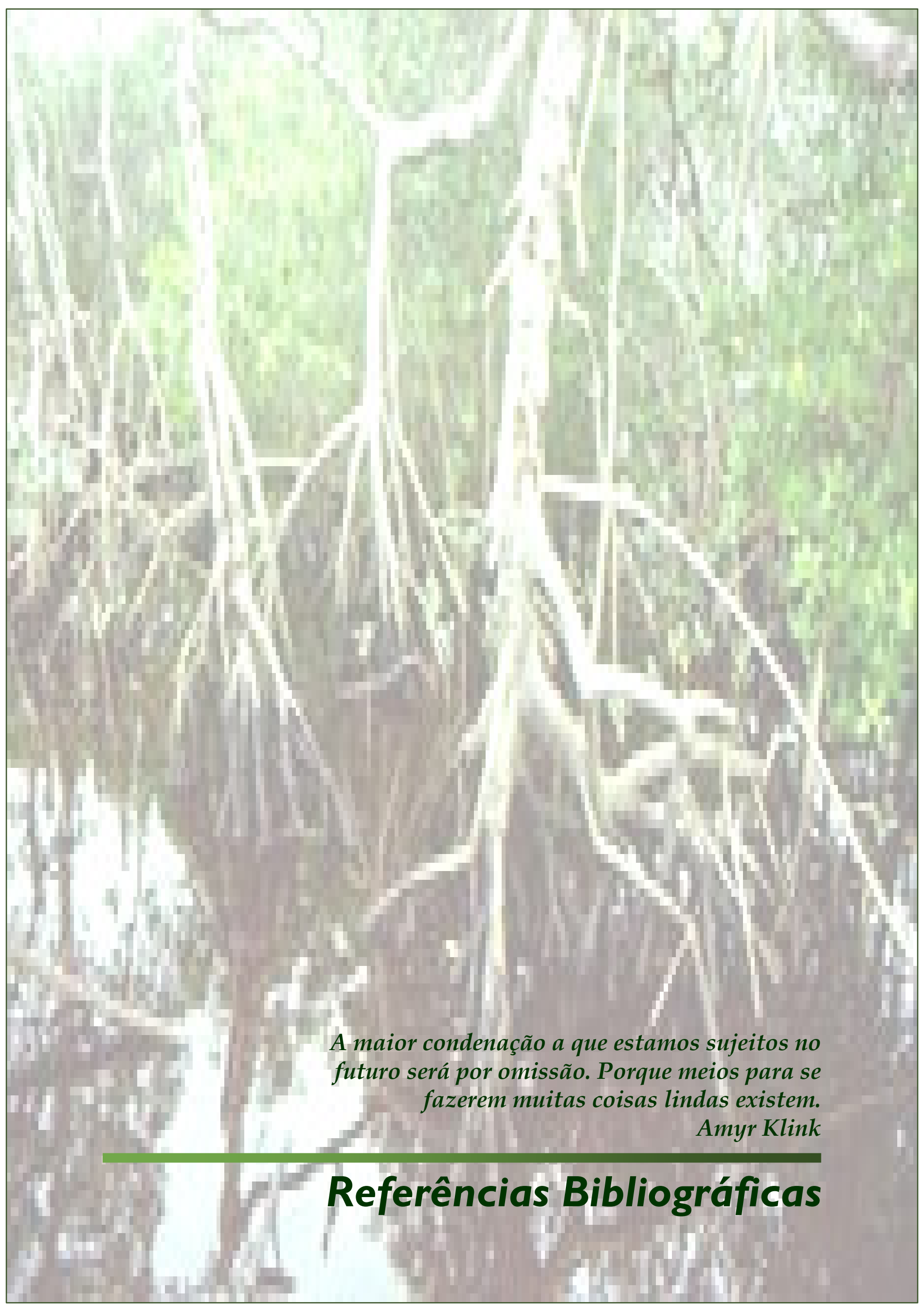




\section{REFERÊNCIAS BIBLIOGRÁFICAS}

ADAMS, W.J. Aquatic toxicology testing methods. In: HOFFMAN, D.J.; RATTNER, B.A.; BURTON JR., G.A.; CAIRNS JR., J. Handbook of ecotoxicology. Boca Raton: Lewis Publications, 1995. p.25-46.

AGÊNCIA NACIONAL DE VIGILÂNCIA SANITÁRIA (ANVISA). Resolução RE no 899, de 29 de maio de 2003 - Guia para Validação de Métodos Analíticos e Bioanalíticos. 2003.

Agency for Toxic Substances and Disease Registry (ATSDR). http:// www.atsdr.cdc.gov/tfacts1.html. Acesso em: 02 nov. 2006.

AHMAD, N.; BUGUENO, G.; GUO, L.; MAROLD, R. Determination of organochlorine and organophosphate pesticide residues in fruit, vegetables, and sediments Shuin. Journal of Environmental Science and Health, v.B34, p.829-848, 1999.

ALLISON, L.E. Organic Carbon. In: BLACK, C.A.; EVANS, D.D.; WHITE, J.L; ENSIMINGER, L.E.; CLARK, F.E.; DDINAUER, R.C. Methods of Soil Analysis. Madison: 1965, p.367-378.

ALMEIDA, F.V. Bases técnico científicas para o desenvolvimento de critérios de qualidade de sedimentos referentes a compostos orgânicos persistentes. 2003. 114p. Tese (Doutorado) - Instituto de Química, Universidade de Campinas, Campinas, 2003.

ALMEIDA, G.A. Resíduos de pesticidas organoclorados no complexo estuarinolagunar Iguape-Cananéia e rio Ribeira de Iguape. 1995. 92p. Dissertação (Mestrado) - Instituto Oceanográfico, Universidade de São Paulo, São Paulo, 1995.

ANJOS, J.A.S.A. Avaliação da eficiência de uma zona alagadiça (wetland) no controle da poluição por metais pesados: o caso da Plumbum em Santo Amaro da Purificação/BA. 2003. 328p. Tese (Doutorado) - Escola Politécnica, Universidade de São Paulo, São Paulo, 2003.

ARAÚJO, A.C.P. et al. Environmental Contam. Toxicology. (1999) 62: 671-676

BACCAN, N. Introdução à Espectrometria de Absorção Atômica. Campinas: Unicamp, 1994.

BEATY, R.D.; KERBER, J.D. Concepts, Instrumentation and Techniques in Atomic Absorption Spectrophotometry. Perkin Elmer Corporation, 1993.

BOLTESMANN, E. Avaliação da Concentração de metais em amostras de sedimentos do reservatório Billings, Braço Rio Grande. 2006. Dissertação (Mestrado) - Instituto de Pesquisa Energéticas Nucleares, Universidade de São Paulo, São Paulo, 2006.

BRAYNER, F.M.M. Determinação de taxas de retenção de metais-traço por sedimentos orgânicos em um viveiro de piscicultura em área estuarina e urbana. 1998. 103p. Tese (Doutorado) - Escola de Engenharia de São Carlos, Universidade de São Paulo, São Carlos, 1998.

BREEMEN, N.V.; BUURMAN, P. Soil formation. Dordrecht: Kluwer, 1998. 376p.

BRUM, A.A.S. Métodos de extração e qualidade da fração lipídica. 2004. 79p. Dissertação (Mestrado) - Escola Superior de Agricultura "Luiz de Queiroz", Universidade de São Paulo, Piracicaba, 2004.

BURTON, G.A.J.; LANDRUM, P.F. Toxicity of sediments. In: MIDDLETON, G.V.; $\mathrm{CHURCH}$, M.J.; CORIGILO, M.; HARDIE, L.A.; LONGSTAFFE, F.J. Encyclopedia of 
sediments and sedimentary rocks. Dordrecht: Kluwer Academic Publishers, 2003. p.748-751.

CANADIAN CONCIL OF MINISTERS OF THE ENVIRONMENT (CCME). Canadian Sediment Quality Guidelines for the Protection of Aquatic Life. 2002.

CANFIELD, D.E.; THAMDRUP, B.; HANSEN, J.W. The anaerobic degradation of organic matter in Danish coastal sediments: Iron reduction, manganese reduction and sulfate reduction. Geochimica et Cosmochimica Acta, London, v.57, p.3867-3883, 1993.

CHAPMAN, P.M. The sediment quality triad approach to determining pollutioninduced degradation. Science of the Total Environment, v.97-98, p.815-823. 1990.

CHARLES, B.; FREDEEN, K. J. Concepts, Instrumentation and Techniques in Inductively Coupled Plasma Optical Emission Spectrometry. Perkin Elmer Corporation, 1997.

CHAU, A.S.Y.; AFGHANM, B.K. Analysis of pesticides in waters. New York: CRC Press, 1982. 437p.

CIOLA, R. Fundamentos da Cromatografia a gás. São Paulo: Edgard Blücher Ltda, 1985. 206p.

COLLINS, C.H.; BRAGA, G.L.; BONATO, P.S. Introdução a métodos cromatográficos. 4ํe․ ed. Campinas: Unicamp, 1990. 279p.

COMPANHIA DE TECNOLOGIA DE SANEAMENTO AMBIENTAL (São Paulo). Lista holandesa de valores de qualidade do solo e da água subterrânea - Valores STI. 1999. São Paulo, 1999.

2001b. 12cap.

Manual de gerenciamento de áreas contaminadas. São Paulo,

Manual de Produtos Químicos. São Paulo, 2003. 29p.

Relatório de qualidade das águas litorâneas do estado de São Paulo: balneabilidade das praias 2003. São Paulo, 2004a. 183p.

Relatório de qualidade das águas interiores do estado de São Paulo - 2003. São Paulo, 2004b. v.1. 273p.

Relatório de estabelecimento de valores orientadores para solos e águas subterrâneas no estado de São Paulo - 2005: em substituição aos valores orientadores de 2001. São Paulo, 2005. 4p.

$141 \mathrm{p}$.

Sistema estuarino de Santos e São Vicente. São Paulo, 2001a.

COOPER, D.C.; MORSE, J.W. Extractability of metal sulfide minerals in acidic solutions: Application to environmental studies of trace metal contamination. Environmental Science \& Technology, Washington, v.32, p.1076-1078, 1998.

CUNHA-LIGNON, M. Dinâmica do manguezal no sistema de Cananéia-Iguape, Estado de São Paulo - Brasil. 2001. 105p. Dissertação (Mestrado) - Instituto Oceanográfico, Universidade de São Paulo, São Paulo, 2001.

Ecologia de Manguezais: Desenvolvimento espaço-temporal no sistema costeiro Cananéia-Iguape, São Paulo, Brasil. 2005. 178p. Tese (Doutorado) Instituto Oceanográfico, Universidade de São Paulo, São Paulo, 2005.

DANTAS, E.S.K. Procedimentos Analíticos em Determinações Multi Elementares de Particulados do Aerossol Atmosférico para Uso em Modelo Receptor. 1999. 
Dissertação (Mestrado) - Instituto de Química, Universidade de São Paulo, São Paulo, 1999.

DI TORO, D.M.; MAHONY, J.D.; HANSEN, D.J.; SCOTT, K.J.; CARLSON, A.R.; ANKLEY, J.T. Acid volatile sulfide predicts the acute toxicity of cadmium and nickel in sediments. Environmental Science \& Technology, Washington, v.26, p.96-101, 1992.

DINELLI, G.; VICARI, A.; CATIZONE, P. Monitoring herbicide pollution in waters by capillary electrophoresis. Journal of Chromatography A, v.733, p.337-347, 1996.

EMPRESA BRASILEIRA DE PESQUISA AGOPECUARIA. Manual de Métodos de Análise de Solo. Rio de Janeiro, 1997.

ENVIRONMENTAL PROTECTION AGENCY. Acid Digestion of sediments, sludges and soils. Method 3050B, 1996, 12p.

Acid digestion of waters for total recoverable or dissolved metals

for analysis by FLAA or ICP spectroscopy. Method 3005A, 1992, 5p.

Soxhlet Extraction. Method 3540C, 1996, 8p.

ESTEVES, F.A. Fundamentos de Limnologia. $2^{\underline{a}}$ ed. Rio de Janeiro: Interciência, 1198. 602p.

EVANKO, C.R.; DZOMBAK, D.A. Remediation of metals-contaminated soils and groundwater. 1997. 53p. GWRTAC "E" Series of reports - Department of Civil and Environmental Engineering, Carnegie Mellon University, Pittsburgh, 1997.

FERNANDES, J.A.; PERIA, L.C.S. Características do Ambiente. In: SCHAEFFERNOVELLI, Y. Manguezal: Ecossistema entre a terra e o mar. São Paulo: Caribbean Ecological Research, 1995. cap.3, p.13-16.

FERREIRA, T.O. Processos pedogenéticos e biogeoquímica de Fe e $\mathbf{S}$ em solos de manguezais. 2005. 141p. Tese (Doutorado) - Escola Superior de Agricultura "Luiz de Queiroz", Universidade de São Paulo, Piracicaba, 2005.

Solos de mangue do rio Crumahú (Guarujá-SP): Pedologia e contaminação por esgoto doméstico. 2002. 113p. Dissertação (Mestrado) - Escola Superior de Agricultura "Luiz de Queiroz", Universidade de São Paulo, Piracicaba, 2002.

FIRME, L.P. Caracterização físico-química de solos de mangue e avaliação de sua contaminação por esgoto doméstico via traçadores fecais. 2003. 70p. Dissertação (Mestrado) - Escola Superior de Agricultura Luiz de Queiroz, Universidade de São Paulo, Piracicaba, 2003.

FÖRSTNER, U.; WITTMANN, G.T.W. Metal pollution in the aquatic environment. $2^{\text {nd }}$ ed. New York: Springer-Verlag, 1981. 486p.

FROELICH, P.N.; KLINKHAMMER, G.B.; BENDER, M.L.; LURDTKE, N.A.; HEATH, G.R.; CULLEN, D.; DAUPHIN, P.; HAMMOND, D.; HARTMAN, B.; MAYNARD, V. Early oxidation of organic matter in pelagic sediments of the eastern equatorial Atlantic: Suboxic diagenesis. Geochimica ed Cosmochimica Acta, London, v.43, p.10751090, 1979.

FRUEHALF, S.P. Rhizophora mangle (Mangue vermelho) em áreas contaminadas de manguezal na Baixada Santista. 2005. 223p. Tese (Doutorado) - Escola Superior de Agricultura "Luiz de Queiroz", Universidade de São Paulo, Piracicaba, 2005.

GATTI, L.V. Distribuição de Metais em Testemunhos de Sedimentos de Duas Lagoas Marginais do Rio Moji-Guaçu (E.E. de Jataí, Luiz Antônio, SP). 1997. Tese (Doutorado) - Universidade Federal de São Carlos, São Carlos, 1997. 
GHISELLI, G. Remediação de Solos Contaminados com Pesticidas Organoclorados utilizando Reagente de Fenton. 2001. 119p. Dissertação (Mestrado) - Universidade de Campinas, Campinas, 2001.

GOLTERMAN, H.L.; CLYMO, R.S.; OHNSTAD, M.A.M. Methods for physical and chemical amalysis of Fresh Water. Blackwell Scientific Publications, 1978. 213p. (IBP Handbook, 8).

GRANDE, M.D. Determinação de compostos organoclorados, pentaclorofenol, hexaclorobenzeno e bifenilas policloradas em água, sedimento e peixes da bacia do rio Piracicaba/SP. 2001. 108p. Dissertação (Mestrado) - Instituto de Química de São Carlos, Universidade de São Paulo, São Carlos, 2001.

GRANDE, M.D.; REZENDE, M.O.O.; ROCHA, O. Distribuição de compostos organoclorados nas águas e sedimentos da bacia do rio Piracicaba/SP - Brasil. Química Nova, São Paulo, v.26, n.5, p.678-686, 2003.

HANDBOOK GOOD LABORATORY PRACTICE: Quality practices for regulated nonclinical research and development (Geneva). UNDP/World Bank/WHO Special Programme for Research and Training in Tropical Diseases (TDR), 2000. 243P.

HINES, M.E.; JONES, G.E. Microbial biogeochemistry in the sediments of Great Bay, New Hampshire. Estuarine, Coastal and Shelf Science, London, v.20, p.729-742, 1985.

HINES, M.E.; LYONS, W.B.; ARMSTRONG, P.B.; OREM, W.H.; SPENCER, M.J.; GAUDETTE, H.E. Seasonal metal remobilization in the sediments of Great Bay, New Hampshire. Marine Chemistry, Amsterdam, v.15, p.173-187, 1984.

HOWARTH, R.W.; MERKEL, S. Pyrite formation and the measurement of sulfate reduction in salt marsh sediments. Limnology Oceanography, Baltimore, v.29, p.598608, 1984.

International Progamme on Chemical Safety (IPCS). Disponível em: http:// www.inchem.org. Acesso em: 02 nov. 2006.

JACKSON, M.L. Soil Chemistry Analysis. New Delhi: India Private, 1967.

JUHÁSZ, C.E.P. Relação solo-água-vegetação em uma toposseqüência localizada na Estação Ecológica de Assis, SP. 2005. 110p. Dissertação (Mestrado) - Escola Superior de Agricultura Luiz de Queiroz, Universidade de São Paulo, Piracicaba, 2005.

KIEHL, E.J. Fertilizantes Orgânicos. São Paulo: Ceres, 1985. 492p.

KRULL, I.; SWARTZ, M. Determining limits of detection and quantification. LC-GC, v.16, p.922-924, 1998.

LACERDA, L.D.; RIBEIRO Jr., M.G.; GUEIROS, B.B. Manganese dynamics in a mangrove mud flat tidal creek in SE Brazil. Mangrove and Salt Marshes, v.3, p.105115, 1999.

LAMPARELLI, C.C. Mapeamento dos Ecossistemas Costeiros do Estado de São Paulo. São Paulo: Secretaria do Meio Ambiente, CETESB, 1998. 108p.

LANÇAS, F. M. Cromatografia em Fase Gasosa. São Carlos: Acta, 1993. 240p. . Extração em Fase Sólida (SPE). São Carlos: Rima, 2004a. 96p. Validação de métodos cromatográficos de análise. São Carlos:

Rima, 2004b. 62p.

LANDGRAF, M.D.; MESSIAS, R.A.; REZENDE, M.O.O. A importância ambiental da vermicompostagem: vantagens e aplicações. São Carlos: Rima, 2005. 106p. 
LARA, W.H.; BATISTA, G.C. Pesticidas. Química Nova, São Paulo, v.15, p.161-166, 1992.

LEE, J.D. Química Inorgânica não tão Concisa. 4aㅗ ed. São Paulo: Edgard Blücher Ltda., 1996. 452p.

LEE, J.S.; LEE, B.G.; LUOMA, S.N.; CHOI, H.J.; KOH, C.H.; BROWN, C.L. Influence of acid volatile sulfides and metal concentrations on metal partitioning in contaminated sediments. Environmental Science \& Technology, Washington, v.34, p.4511-4516, 2000.

LEITÃO, S.N. A fauna do manguezal. In: SCHAEFFER-NOVELLI, Y. Manguezal: Ecossistema entre a terra e o mar. São Paulo: Caribbean Ecological Research, 1995. cap.5, p.23-28.

LEITE, M.A. Análise do aporte, da taxa de sedimentação e da concentração de metais na água, plâncton e sedimento do Reservatório de Salto Grande, Americana-SP. 2002. 199p. Tese (Doutorado) - Escola de Engenharia de São Carlos, Universidade de São Paulo, São Carlos, 2002.

LEMES, M. J. L. L. Avaliação de Metais e Elementos-Traço em Águas e Sedimentos das Bacias Hidrográficas do rios Mogi-Guaçu e Pardo, São Paulo. 2001. Dissertação (Mestrado) - Instituto de Pesquisa Energéticas Nucleares, Universidade de São Paulo, São Paulo, 2001.

LONG, L.G.; WINWFORDER, J.D. Limit of Detection: A closer at the IUPAC definition. Analytical Chemistry, v.55, p.712A-724A, 1983.

MACCARTHY, P.; MALCOLM, R.L.; CLAPP, C.E.; BLOOM, P.R. An introduction to soil humic substances. In: MACCARTHY, P.; CLAPP, C.E.; MALCOLM, R.L.; BLOOM, P.R. Humic substances in soil and crop sciences: selected readings. Madison: American Society of Agronomy, 1990. cap.1, p.1-12.

MARIANI, C.F. Reservatório Rio Grande: caracterização limnológica da água e biodisponibilidade de metais-traço no sedimento. 2006. 123p. Dissertação (Mestrado) - Instituto de Biociências, Universidade de São Paulo, São Paulo, 2006.

MATOS, M.A.C.; WEBER, R.R. Estudo dos níveis de contaminação por pesticidas organoclorados e bifenílos policlorados em sedimento marinho do complexo estuarino-lagunar de Cananéia (SP). Disponível em: <http://www.sbq.org.br/ranteriores/23/resumos/0097/>. Acesso em: 27 ago. 2004.

MCKEE, K.L. Soil physicochemical patterns and mangrove species distributionreciprocal effects. The Journal of Ecology, Oxford, v.81, p.477-487, 1993.

MCKEE, K.L.; MENDELSSOHN, I.A.; HESTER, M.W. Reexamination of pore water sulfide concentrations and redox potentials near the aerial roots of Rhizophora mangle and Avicennia germinans. American Journal of Botany, Columbus, v.75, p.13521359, 1988.

MORAES, S.L. Comportamento de herbicidas clorados em sistemas aquáticos na presença de substâncias húmicas utilizando eletroforese capilar. 2003. 163p. Tese (Doutorado) - Instituto de Química de São Carlos, Universidade de São Paulo, São Carlos, 2003.

MOZETO, A.A. Sedimentos e Particulados Lacustres: amostragem e análises biogeoquímicas. In: BICUDO, C.E.M.; BICUDO, D.C. Amostragem em Limnologia. São Paulo: Rima, 2004. p.295-320.

O'NEILL, P. Environmental Chemistry. $2^{\text {nd }}$ ed. London: Chapman \& Hall, 1993. 268p.

OLIVARES, I.R.B. Desenvolvimento, otimização e validação da técnica HS-SPMEGC/MS para análise de amostras obtidas do Rio Atibaia através da aplicação de 
uma sistemática "ISO" para diagnóstico ambiental de áreas contaminadas. 2006. 191p.Tese (Doutorado) - Instituto de Química de São Carlos, Universidade de São Paulo, São Carlos, 2006.

OLIVEIRA, E.C. Aspectos limnológicos e sanitários de uma lagoa costeira no litoral leste do Ceará - Lagoa do Batoque. 2006. 163p. Dissertação (Mestrado) Escola de Engenharia de São Carlos, Universidade de São Paulo, São Carlos, 2006.

OLIVEIRA, R.M.; BASTOS, L.H.P.; DIAS, A.E.X.; SILVA, S.A.; MOREIRA, J.C. Concentração residual de hexaclorociclohexano em área contaminada na Cidade dos Meninos, Duque de Caxias, Rio de Janeiro, Brasil, após tratamento com óxido de cálcio. Caderno de Saúde Pública, Rio de Janeiro, v.19, p.447-453, 2003.

OLIVEIRA, S.S.; BRITTO, I.C.; FREITAS, H.M.B. Composição química das folhas da Rhizophora mangle L. e do sedimento de manguezais não impactados e impactados por resíduos industriais. Sitientibus, Feira de Santana, n.23, p.35-44, 2000.

OTERO, X.L.; MACÍAS, F. Variation with depth and season in metal sulfides in salt marsh soils. Biogeochemistry, Dordrecht, v.61, p.247-268, 2002.

PONNAMPERUMA, F.N. The chemistry of submerged soil. Advances in Agronomy, v.24, p.29-96, 1972.

POR, F.D. The ecosystem of the mangal: general considerations. In: POR, F.D.; DOR, I. Hydrobiology of the Mangal: The Ecosystem of the Mangrove Forests. Boston: Dr. W. Junk Publishers, 1984. p.1-14.

PURVES, D. Trace-element contamination of the environment. Amsterdam: Elsevier, 1985. 243p.

QUINÁGLIA, G.A. Estabelecimento de um protocolo analítico de preparação de amostras de solo para determinação de metais e sua aplicação em um estudo de caso. 2001. 164p. Dissertação (Mestrado) - Faculdade de Saúde Pública, Universidade de São Paulo, São Paulo, 2001.

REIS, T.C. Distribuição e Disponibilidade do Níquel Aplicado ao Solo como $\mathbf{N i C l}_{2}$ e Biossólido. 2002. 118p. Tese (Doutorado) - Escola Superior de Agricultura "Luiz de Queiroz", Universidade de São Paulo, Piracicaba, 2002.

REZENDE, M.O.O. A importância ambiental das substâncias húmicas. 1999. 152p. Tese (Livre Docência) - Instituto de Química de São Carlos, Universidade de São Paulo, São Carlos, 1999.

ROCHA, J.C.; ROSA, A.H.; CARDOSO, A.A. Introdução à Química Ambiental. Porto Alegre: Bookman, 2004. 154p.

ROSINI, A. Análise temporal do complexo estuarino da Baixada Santista/SP, por meio de imagens TM-Landsat. Disponível em:

SANTOS, E. J. Determinação de nutrientes e contaminantes inorgânicos em café solúvel por Espectrometria de Emissão Atômica com Plasma de Argônio Induzido (ICP-AES). 1999. Dissertação (Mestrado) - Instituto de Química, Universidade de São Paulo, São Paulo, 1999.

SANTOS, S. Determinação de PCBs em ambiente lacustre. 2000. 90p. Dissertação (Mestrado) - Instituto de Química de São Carlos, Universidade de São Paulo, São Carlos, 2000.

SCHAEFFER-NOVELLI, Y. Manguezais Brasileiros. 1991. 42p. Tese (Livre Docência) - Instituto Oceanográfico, Universidade de São Paulo, São Paulo, 1991.

Manguezal: Ecossistema entre a terra e o mar. São Paulo: Caribbean Ecological Research, 1995. 64p. 
SCHAEFFER-NOVELLI, Y.; CINTRÓN, G. Guia para estudo de áreas de manguezal: estrutura, função e flora. São Paulo, Caribbean Ecological Research, 1986. 150p.

Manguezais Brasileiros: uma síntese sobre aspectos históricos (séculos XVI a XIX), zonação, estrutura e impactos ambientais. In: SIMPÓSIO DE ECOSSISTEMAS DA COSTA BRASILEIRA, Serra Negra, 1993. Anais. Serra Negra: ACIESP, 1994. p.333-341.

SCHAEFFER-NOVELLI, Y.; LACERDA, L.D. Lagoas costeiras, manguezais, marismas, dunas e restingas. In: PANITZ, C.M.N. (Coord.). Diagnóstico Ambiental oceânico e costeiro das regiões Sul e Sudeste do Brasil. São Paulo: Fundespa; IOUSP; Petrobrás, 1994. p.128-347.

SCHMIDT, G. Manguezal de Cananéia, concentração dos elementos químicos carbono, nitrogênio, cálcio, fósforo, manganês, ferro e cinzas, em folhas de mangue e sua correlação com taxa de decomposição e salinidade. 1988. 369p. Tese (Doutorado) - Instituto Oceanográfico, Universidade de São Paulo, São Paulo, 1988.

SCHNITZER, M. Humic Substances: Chemistry reactions. In: SCHNITZER, M.; KHAN, S.U. Soil Organic Matter. Amsterdam: Elsevier, 1978. p.1-64.

SCHNITZER, M.; KODAMA, H.; RIPMEESTER, J.A. Determination of the aromaticity of humic substances by X-ray diffraction analysis. Soil Science Society American Journal, v.55, p.745-750, 1991.

SCHULTEN, H.R; SCHNITZER, M. A state of the art structural concept for humic substances. Naturwissenschaften, v.80, p.29-30, 1993.

Chemical model structures for soil organic matter and soils. Soil Science, v.162, p.115-130, 1997.

SCHULZ, H.D. Redox measurements in marine sediments. In: SCÜRING, J.; SCHULZ, H.D.; FISCHER, W.R.; BÖTTCHER, J.; DUIJNISVELD, W.H.M. Redox: Fundamentals Processes and Applications. Berlin: Springer, 2000. cap.19, p.235-246.

SEIN Jr., L.T.; VARNUM, J.M.; JANSEN, S.A. Conformational modeling of a new building block of humic acid: approaches to the lowest energy conformer. Environmental Science and Technology, v.33, p.546-552, 1999.

SKOOG, D.A.; HOLLER,F.J.; NIEMAN, T.A. Princípios de Análise Instrumental. 5aㅗ ed. Porto Alegre: Bookman, 2002. 836p.

SMITH, L.A.; MEANS, J.L.; CHEN, A.; ALLEMAN, B.; CHAPMAN, C.C.; TIXIER Jr., J.S.; BRAUNING, S.E.; GAVASKAR, A.R.; ROYER, M.D. Remedial options for metals-contaminated sites. New York, CRC Press, 1995. p.17-33.

SOARES, M.L.G. Zonação e as marés. In: SCHAEFFER-NOVELLI, Y. Manguezal: Ecossistema entre a terra e o mar. São Paulo: Caribbean Ecological Research, 1995. cap.8, p.35-38.

STEVENSON, F.J. Humus Chemistry: genesis, composition, reactions. $2^{\text {nd }}$ ed. New York. John Wiley \& Sons, 1994. 496p.

SUGIYAMA, M. A flora do manguezal. In: SCHAEFFER-NOVELLI, Y. Manguezal: Ecossistema entre a terra e o mar. São Paulo: Caribbean Ecological Research, 1995. cap.4, p.17-22.

SWIFT, R.S. Organic matter characterization. In: SPARKS, D.L. et al. Methods of soil analysis: Part 3 - Chemical methods. Soil Science Society of America Book Series: 5. Madison: University of Wisconsin, 1996, chap.35, p.1018-1020. 
THOMAS, R.L. A protocol for the selection of process-oriented remedial options to control in situ sediment contaminants. Hydrobiology, Sofia, v.149, p.247-258, 1987.

THOMPSON, M. Analytical Performance of Inductively Coupled Plasma Atomic Emission Spectrometry. In: MONTASER, A.; GOLIGHTLY, D.W. Inductively Coupled Plasma in Analytical Spectrometry. New York: VHC publishers INC, 1987, p.163199.

TOMAZELLI, A.C. Estudo comparativo das concentrações de cádmio, chumbo e mercúrio em seis bacias hidrográficas do estado de São Paulo. 2003. 124p. Tese (Doutorado) - Faculdade de Filosofia, Ciências e Letras de Ribeirão Preto, Universidade de São Paulo, Ribeirão Preto, 2003.

UNILIVRE. Produção de Ostras de Mangue no Estuário de Cananéia/SP. Disponível em:

VANNUCCI, M. Os Manguezais e Nós. São Paulo: Editora da Universidade de São Paulo, 1999. 233p.

VARJABEDIAN, R. Impactos sobre os manguezais. In: SCHAEFFER-NOVELLI, Y. Manguezal: Ecossistema entre a terra e o mar. São Paulo: Caribbean Ecological Research, 1995. cap.11, p.49-52.

WERF, V.D.; HAYO, M.G. Assessing the impact on the environmental Agriculture. Ecosystems and Environmental, v.60, p.81-96, 1996.

YABE, M. J. S. Determinação de Metais Pesados em Águas Superficiais por ICPAES Objetivando Caracterização e Recuperação de Bacias Hidrográficas. 1995. Tese (Doutorado) - Universidade de São Paulo, São Paulo, 1995.

YOGUI, G.T. Ocorrência de compostos organoclorados (pesticidas e PCBs) em mamíferos marinhos da costa de São Paulo (Brasil) e da Ilha Rei George (Antártica). 2002. 139p. Dissertação (Mestrado) - Instituto Oceanográfico, Universidade de São Paulo, São Paulo, 2002.

YOKOYA, N.S. Distribuição e origem. In: SCHAEFFER-NOVELLI, Y. Manguezal: Ecossistema entre a terra e o mar. São Paulo: Caribbean Ecological Research, 1995. cap.2, p.9-12.

ZAMBETTA, P.M.A. Espécies químicas inorgânicas (Al, As, Cd, Cr, Cu, Fe, $\mathbf{H g}$, $\mathrm{Mn}, \mathrm{Ni}, \mathrm{Pb}$ e $\mathrm{Sn}$ ) no sedimento e nos sólidos em suspensão do Rio Corumbataí, SP. 2006. 73p. Dissertação (Mestrado) - Escola Superior de Agricultura "Luiz de Queiroz", Universidade de São Paulo, Piracicaba, 2006. 